FACULDADE DE FILOSOFIA, LETRAS E CIÊNCIAS HUMANAS

PÓS GRADUAÇÃO EM GEOGRAFIA FÍSICA

\title{
KÁTIA FERNANDA PEREIRA MARQUES
}

Alterações no uso e cobertura da terra na Bacia Hidrográfica do Rio Buquira - Monteiro Lobato (SP) entre os anos de 1985 e 2015

Versão corrigida

São Paulo 


\section{KÁTIA FERNANDA PEREIRA MARQUES}

Alterações no uso e cobertura da terra na Bacia Hidrográfica do Rio Buquira - Monteiro Lobato (SP) entre os anos de 1985 e 2015

Versão corrigida

Tese de Doutorado apresentada ao Programa de Pós-graduação em Geografia Física, da Faculdade de Filosofia, Letras e Ciências Humanas, da Universidade de São Paulo, como parte dos requisitos para obtenção do Título de Doutora em Geografia.

Orientador: Prof. Dr. Tarik Rezende de Azevedo 
UNIVERSIDADE DE SÃO PAULO

FACULDADE DE FILOSOFIA, LETRAS E CIÊNCIAS HUMANAS

\section{ENTREGA DO EXEMPLAR CORRIGIDO DA DISSERTAÇ̃̃O/TESE Termo de Ciência e Concordância do (a) orientador (a)}

Nome do (a) aluno (a): KÁTIA FERNANDA PEREIRA MARQUES

Data da defesa: 19

Nome do Prof. (a) orientador (a): TARIK REZENDE DE AZEVEDO

Nos termos da legislação vigente, declaro ESTAR CIENTE do conteúdo deste EXEMPLAR CORRIGIDO elaborado em atenção às sugestões dos membros da comissão Julgadora na sessão de defesa do trabalho, manifestando-me plenamente favorável ao seu encaminhamento e publicação no Portal Digital de Teses da USP.

São Paulo, $25 / 03 / 2020$

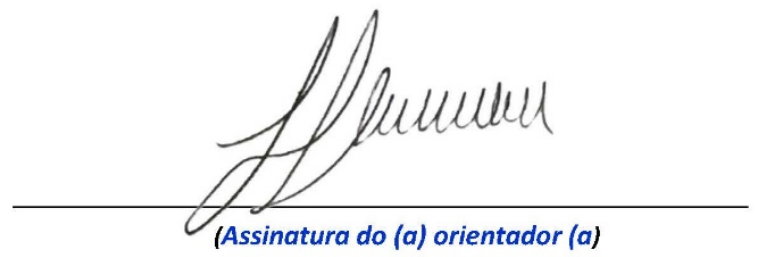


Catalogação na Publicação

Serviço de Biblioteca e Documentação

Faculdade de Filosofia, Letras e Ciências Humanas da Universidade de São Paulo

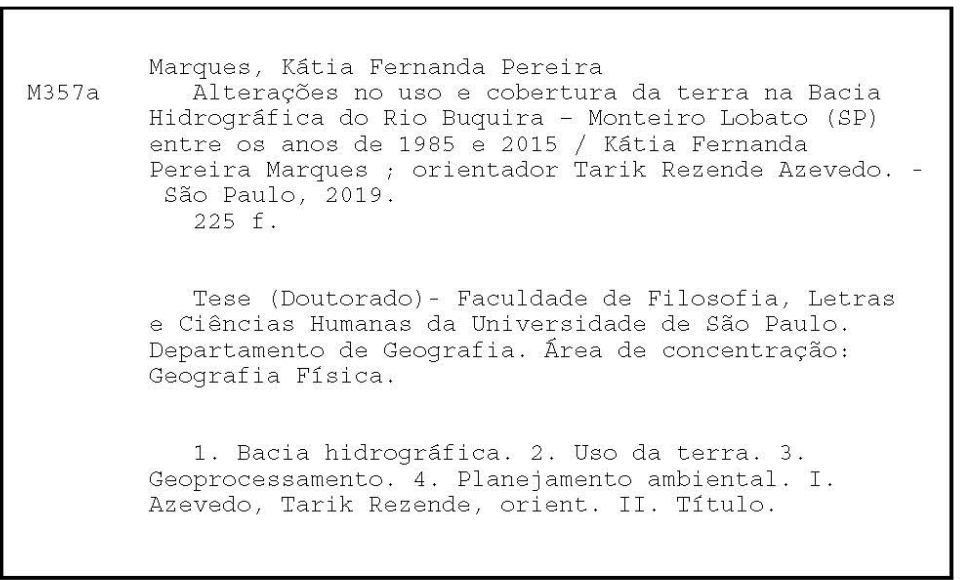




\section{Agradecimentos}

Agradeço, inicialmente, a Deus, que me proporcionou o benefício de estar aqui e hoje escrevendo. Ele me guiou nas horas de incerteza e me ajudou a manter a serenidade para não desistir. Deu força e saúde quando precisei renascer. E em dias de chuva ou sol, manteve minha fé!

Ao meu orientador Prof. Dr. Tarik Rezende de Azevedo, pela sua infinita paciência e disposição. Sempre foi muito solícito quando precisei. Quero expressar minha admiração pelo seu trabalho! Confesso que o último "boa sorte" que me deu, foi o que eu precisava ouvir para concretizar este trabalho. Foi como se eu ouvisse: "Vai dar tudo certo!". Ao professor, muito obrigada.

À meus queridos pais Lourdes e José, pelos valores pessoais que cultivo diariamente, pelas palavras de estímulo, pelos alegres almoços de domingo, por cuidarem de mim quando fiz as cirurgias e por tantas novenas oferecidas em meu nome! Amo vocês.

Ao meu marido José Fernando ("enchufinho"), que me conheceu no começo da tese, casou-se comigo no meio, e que permaneceu junto a mim ao findar desta etapa. Obrigada pelo companheirismo, pela compreensão nos momentos em que estive ausente estudando no escritório até de madrugada, por me amparar quando não encontrava algum dado importante para a pesquisa, ou quando me desesperava se algum mapa dava errado no ArcGis! Precisei desse carinho.

Ao meu irmão Cristiano, por me incentivar a estudar para fazer parte de uma universidade pública, por ir comigo nos trabalhos de campo, por debatermos tantas questões acadêmicas, por reler meu trabalho, por acreditar no meu potencial e por ser um ótimo irmão.

Ao amigo Sullivan, que me acompanhou aos órgãos do governo para pesquisa de informações sobre a área da bacia, ao querido Edinho, que é parceiro desde a Unesp de Prudente e que cedeu dias me ensinando a utilizar o Idrisi, à amiga Juzinha por compartilhar discussões sobre esta tese, ao amigo Fabião por sempre dizer "vai pra cima"! À Bruna e Paula, pelas orações. À Luciana e Joyce pela amizade em todo este período. 
Aos amigos(as) e direção da escola que dou aula, que me incentivaram nos momentos em que não conseguia conciliar trabalho e vida acadêmica, e entenderam que, por vezes, tive que me ausentar.

Aos outros grandes amigos(as) da luta diária.

Ao Rogério do Laboratório de Climatologia e Biogeografia, por ser tão prestativo e ao Pablo do Laboratório de Aerofotogrametria e Sensoriamento Remoto por auxiliar na localização das fotos aéreas da área da bacia.

Ao Prof. Dr. Antonio Cézar Leal, ao Prof. Dr. José Manuel Mateo Rodríguez (in memorian) e à todos os professores que contribuíram para minha formação acadêmica.

Ao Programa de Pós-Graduação em Geografia Física da USP, pela oportunidade de realização deste trabalho e aos funcionários da Secretaria da Pós, em especial, a Cida que sempre foi atenciosa e ágil em ajudar.

Ao Conselho Nacional de Desenvolvimento Científico e Tecnológico (CNPq), por conceder a bolsa de auxílio para esta pesquisa. 
O sexto planeta era dez vezes maior. Era habitado por um velho que escrevia em livros enormes.

- Ora vejam! Eis um explorador! - exclamou ele, logo que avistou o pequeno príncipe.

O principezinho sentou-se à mesa, meio ofegante. Já viajara tanto!

- De onde vens? - perguntou-lhe o velho.

- Que livro é esse? - perguntou-Ihe o pequeno príncipe. Que faz o senhor aqui?

- Sou geógrafo - respondeu o velho.

- Que é um geógrafo? - perguntou o principezinho.

- É um especialista que sabe onde se encontram os mares, os rios, as cidades, as montanhas, os desertos.

- Isto é bem interessante - disse o pequeno príncipe. - Eis, afinal, uma verdadeira profissão! 


\section{Alterações no uso e cobertura da terra na Bacia Hidrográfica do Rio Buquira - Monteiro Lobato (SP) entre os anos de 1985 e 2015}

Resumo: Nesta tese, apresentamos estudos acerca do uso e cobertura da terra na Bacia Hidrográfica do Rio Buquira, localizada nos municípios de Monteiro Lobato e São José dos Campos (SP), tendo como proposta a comparação das séries históricas de 1985 a 2015, em um período total de 30 anos. Ao longo do tempo, ocorreram diversas transformações no meio natural e antrópico, decorrente de toda uma conjuntura histórica, econômica, social e cultural das épocas em questão. Ocorreram mudanças como a supressão de floresta primária para o estabelecimento de pastagens, a reestruturação desta mesma floresta primária, o crescimento de áreas de reflorestamento, o aumento e o retrocesso de áreas urbanas nos anos mais recentes, a composição de novas áreas sobre solo exposto e a manutenção considerável de corpos d'água, em meio a transposições e canalizações. Para a identificação destas mudanças, utilizamos a metodologia de Leal (1995); Rodriguez (2010). Adquirimos as imagens de satélite do sensor Landsat 5 e 8, dos anos de 1985, 1995, 2005 e 2015, classificamos no software ArcGis 10.4 e processamos as mudanças temporais no software Idrisi versão Taiga, com o módulo Land Change Modeler (LCM), que identifica tais mudanças ocorridas nos diferentes períodos. Assim, obtivemos como produto a carta de Ganhos e Perdas da terra, a carta-síntese de Mudanças e a carta de Predição de mudanças para os próximos 30 anos. As demais cartas ambientais, como a carta de Suscetibilidade à erosão, foram importantes para os estudos, principalmente no que tange as áreas de alagamento na bacia.

Palavras-chave: Uso e cobertura da terra; bacia hidrográfica, Rio Buquira, Geoprocessamento, Land Change Modeler 


\title{
Changes in land use and land cover in the Buquira River Basin - Monteiro Lobato (SP) between 1985 and 2015
}

\begin{abstract}
In this article, we present studies of the use and occupation of the Buquira River Basin, located in the municipalities of Monteiro Lobato and São José dos Campos (SP), with the purpose of comparing historical statistics from 1985 to 2015 , over a total period. 30 years old. Over time, there are several transformations in the natural and anthropic environment, resulting from a whole historical, economic, social and cultural conjuncture of the times in question. There have been changes such as the suppression of primary forest for pasture establishment, a restructuring of that forest, the growth of reforestation areas, the increase and return of urban areas in recent years, a composition of new areas on exposed soil and considerable maintenance. bodies of water through transposition and channeling. To identify these changes, we used the methodology of Leal (1995), Rodriguez (2010). Acquired as satellite images from the Landsat5 and 8 sensor from 1985, 1995, 2005 and 2015, classified as ArcGis 10.4 software and processed as temporary changes to Idrisi Taiga version software, with the Land Change Modeler (LCM) module, which identifies as temporal changes occurring in different variations. So get a Land Gains and Loss chart, a Change statistics chart, and a change prediction chart for the next 30 years. Like other environmental charters, such as an Erosion susceptibility charter, they were important for studies, especially regarding the areas of flooding in the basin.
\end{abstract}

Keywords: Land use and land cover; river basin, Buquira River, Georprocessing, Land Change Modeler 


\section{SUMÁRIO}

INTRODUÇÃO 17

1.CAPÍTULO I - FUNDAMENTAÇÃO TEÓRICA 21

1.1. A paisagem e o conceito de paisagem antropogênica 22

1.2. Uso e cobertura da terra e interações antrópicas 25

1.3. Manejo integrado de bacias hidrográficas e planejamento do uso do 30 solo urbano e rural

1.4. Perigo, vulnerabilidade e riscos ambientais 34

1.5. O contexto da bacia do Rio Buquira no Vale do Paraíba 38

1.6. São José dos Campos: história e desenvolvimento econômico 43

1.7. Legislação Ambiental na Bacia do Rio Buquira 55

2. CAPÍTULO II - PROCEDIMENTOS METODOLÓGICOS 60

2.1. Documentação cartográfica 63

2.2. As ferramentas cartográficas $\quad 63$

2.3. Mapeamento temático 64

2.4. O módulo LCM 67

2.5. Trabalhos de campo 68

3. CAPÍTULO III - Caracterização da Bacia Hidrográfica 81

3.1. Inventário da Bacia Hidrográfica do Rio Buquira (Monteiro Lobato - 82 $\mathrm{SP})$

3.1.1. Hipsometria $\quad 89$

3.1.2. Declividade 92

3.1.3. Geologia 95

3.1.4. Pedologia $\quad 97$

3.1.5 Geomorfologia 100

3.1.6. Clima 102

3.1.7. Uso e cobertura da terra 105

3.1.8. Hidrologia 108

3.1.8.1. Breve análise da qualidade da água 114

4. CAPÍTULO IV - RESULTADOS 117

4.1. Contexto histórico em pequena e grande escala: as 118 mudanças ocorridas na Bacia do Rio Buquira 
4.2. Cartas de uso e cobertura da terra para os anos de 1985, 1995, 128 2005 e 2015

4.2.1. Uso e cobertura da terra em 1985

4.2.2. Uso e cobertura da terra em 1995

4.2.3. Uso e cobertura da terra em 2005

4.2.4. Uso e cobertura da terra em 2015 138

4.3. Análise dos ganhos e perdas no uso da terra (por categoria)

4.3.1. Ganhos e perdas da terra para a categoria Área construída

4.3.2. Ganhos e perdas da terra para a categoria Pastagem 149

4.3.3. Ganhos e perdas da terra para a categoria Solo Exposto 156

4.3.4. Ganhos e perdas da terra para a categoria Reflorestamento 163

4.3.5. Ganhos e perdas da terra para a categoria Floresta primária 170

4.3.6. Ganhos e perdas da terra para a categoria Vegetação 179 secundária

4.3.7. Ganhos e perdas da terra para a categoria Água 186

4.4. Principais mudanças no Uso da terra entre 1985 e 2015 193

4.5. Suscetibilidade, riscos e alagamentos $x$ Predição de mudanças 198 para a área da bacia CONSIDERAÇÕES FINAIS 


\section{Lista de Figuras}

Figura 1: Classificação sintética das paisagens antropogênicas

Figura 2: Etapas de levantamento e classificação do uso e cobertura da terra 27 Níveis I e II (IBGE, 2006)

Figura 3: Fases do Planejamento Ambiental 31

Figura 4: Diagrama de interação indicando as consequências do processo de urbanização sobre os processos de escoamento das águas superficiais.

Figura 5: Brasão original de São José dos Campos, pintado por J. Wasth 44 Rodrigues.

Figura 6: Atividade do satélite LANDSAT (1972-até os dias atuais) 66

Figura 7: Execução do banco de dados no software Idrisi 68

Figura 8: Pontos visitados nos trabalhos de campo na área de pesquisa 70

Figura 9: Área de inundações no Bairro Mirante do Buquirinha, em imagem 75 do Google Earth e três exemplos de ocorrências: ano de 2009, 2013 e 2016 Figura 10: Série de fotos sobre a inundação do dia 16 de janeiro de 2016.

Figura 11: Rio Buquira, apresentando a preservação de sua mata ciliar 76

Figura 12: Ponte na SP-50, próximo ao curso d'água 77

Figura 13: Assoreamento do Rio Buquira 78

Figura 14: Disposição inadequada de lixo no entorno aos corpos d'água 78

Figura 15: Lançamento de esgotos domésticos no leito do rio Buquira 79

Figura 16: Desocupação parcial da margem direita do rio. 79

Figura 17: Margem esquerda do rio ainda ocupada 80

Figura 18: Mapa da Divisão Político-administrativa: Bacia Hidrográfica do Rio 80 Buquira

Figura 19: Mapa base da Bacia Hidrográfica do Rio Buquira - Monteiro 84 Lobato (SP)

Figura 20: Evolução Populacional do Município de São José dos Campos 86 (1940-2010)

Figura 21: Carta Hipsométrica da Bacia Hidrográfica do Rio Buquira - 91 Monteiro Lobato (SP)

Figura 22: Carta Clinográfica da Bacia Hidrográfica do Rio Buquira - Monteiro 94 Lobato (SP) 
Figura 23: Carta Geológica da Bacia Hidrográfica do Rio Buquira - Monteiro 96 Lobato (SP)

Figura 24: Perfis topográficos da Bacia Hidrográfica do Rio Buquira - 97 Monteiro Lobato

Figura 25: Carta Pedológica da Bacia Hidrográfica do Rio Buquira - Monteiro 99 Lobato (SP)

Figura 26: Carta dos Compartimentos Geomorfológicos da Bacia 101 Hidrográfica do Rio Buquira - Monteiro Lobato (SP)

Figura 27: Matriz dos índices de dissecação do relevo 102

Figura 28: Gráfico de Chuva acumulada X Chuva acumulada mensal (normal 104 climatológica) para o ano de 2015.

Figura 29: Foto aérea do ano de 1962 da Bacia Hidrográfica do Rio Buquira 106

Figura 30: Imagem do Google Earth de 2015 da Bacia Hidrográfica do Rio 106 Buquira

Figura 31: Chave de interpretação para imagens TM/Landsat para uso da 107 terra

Figura 32: Carta de Hierarquia Fluvial da Bacia Hidrográfica do Rio Buquira 110 (Monteiro Lobato - SP)

Figura 33: Pontos de coleta de amostras para análise da água 114

Figura 34: Carta de uso e cobertura da terra para o ano de 1985 131

Figura 35: Carta de uso e cobertura da terra para o ano de 1995 134

Figura 36: Carta de uso e cobertura da terra para o ano de 2005 137

Figura 37: Carta de uso e cobertura da terra para o ano de 2015

Figura 38: Mapa de ganho e perda na categoria Área construída. (1985-1995) 143

Figura 39: Mapa de ganho e perda na categoria Área construída. (1995-2005 145

Figura 40: Mapa de ganho e perda na categoria Área construída (2005-2015) 147

Figura 41: Mapa de ganho e perda na categoria Pastagem (1985-1995) 150

Figura 42: Mapa de ganho e perda na categoria Pastagem (1995-2005) 152

Figura 43: Mapa de ganho e perda na categoria Pastagem (2005-2015) 154

Figura 44: Mapa de ganho e perda na categoria Solo exposto (1985-1995) 157

Figura 45: Mapa de ganho e perda na categoria Solo exposto (1995-2005) 159

Figura 46: Mapa de ganho e perda na categoria Solo exposto (2005-2015) 161

Figura 47: Mapa de ganho e perda na categoria Reflorestamento (1985- 164 1995) 
Figura 48: Mapa de ganho e perda na categoria Reflorestamento (1995- 166 2005)

Figura 49: Mapa de ganho e perda na categoria Reflorestamento (2005- 168 2015)

Figura 50: Mapa de ganho e perda na categoria Floresta primária (1985- 172 1995)

Figura 51: Mapa de ganho e perda na categoria Floresta primária (1995- 175 2005)

Figura 52: Mapa de ganho e perda na categoria Floresta primária (2005- 177 2015)

Figura 53: Mapa de ganho e perda na categoria Vegetação secundária 180 (1985-1995)

Figura 54: Mapa de ganho e perda na categoria Vegetação secundária 182 (1995-2005)

Figura 55: Mapa de ganho e perda na categoria Vegetação secundária 184 (2005-2015)

Figura 56: Mapa de ganho e perda na categoria Água (1985-1995) 187

Figura 57: Mapa de ganho e perda na categoria Água (1995-2005) 189

Figura 58: Mapa de ganho e perda na categoria Água (2005-2015) 191

Figura 59: Mapa de mudanças do uso da terra na área da bacia (entre 1985196 e 2015)

Figura 60: Construções irregulares em áreas de APP's 199

Figura 61: Carta de Suscetibilidade à Erosão na Bacia Hidrográfica do Rio 203 Buquira

Figura 62: Placa em local de área de risco 204

Figura 63: Carta de predição de mudanças no Uso da terra na Bacia 209 Hidrográfica do Rio Buquira 


\section{Lista de gráficos}

Gráfico 1: Lançamentos de efluentes em corpos d'água superficiais no 88 município de Monteiro Lobato

Gráfico 2: Suscetibilidade à escorregamentos em Monteiro Lobato 89

Gráfico 3: Ganhos e perdas de terra na categoria Área construída (1985-1995) 142

Gráfico 4: Ganhos e perdas de terra na categoria Área construída (1995-2005) 144

Gráfico 5: Ganhos e perdas de terra na categoria Área construída (2005-2015) 146

Gráfico 6: Ganhos e perdas de terra na categoria Pastagem (1985-1995) 149

Gráfico 7: Ganhos e perdas de terra na categoria Pastagem (1995-2005) 151

Gráfico 8: Ganhos e perdas de terra na categoria Pastagem (2005-2015) 153

Gráfico 9: Ganhos e perdas de terra na categoria Solo exposto (1985-1995) 156

Gráfico 10: Ganhos e perdas de terra na categoria Solo exposto (1995-2005) 158

Gráfico 11: Ganhos e perdas de terra na categoria Solo exposto (2005-2015) 160

Gráfico 12: Ganhos e perdas de terra na categoria Reflorestamento (1985- 163 1995)

Gráfico 13: Ganhos e perdas de terra na categoria Reflorestamento (1995- 165 2005)

Gráfico 14: Ganhos e perdas de terra na categoria Reflorestamento (2005- 167 2015)

Gráfico 15: Ganhos e perdas de terra na categoria Floresta primária (1985- 171 1995)

Gráfico 16: Ganhos e perdas de terra na categoria Floresta primária (1995- 173 2005)

Gráfico 17: Ganhos e perdas de terra na categoria Floresta primária (2005- 176 2015)

Gráfico 18: Ganhos e perdas de terra na categoria Vegetação secundária (1985- 179 1995)

Gráfico 19: Ganhos e perdas de terra na categoria Vegetação secundária (1995- 181 2005)

Gráfico 20: Ganhos e perdas de terra na categoria Vegetação secundária (2005- 183 2015)

Gráfico 21: Ganhos e perdas de terra na categoria Água (1985-1995) 186

Gráfico 22: Ganhos e perdas de terra na categoria Água (1995-2005) 
Gráfico 23: Ganhos e perdas de terra na categoria Água (2005-2015) 190

Gráfico 24: Mudanças no uso da terra entre 1985 e 1995 (em ha) 193

Gráfico 25: Mudanças no uso da terra entre 1995 e 2005 (em ha) 194

Gráfico 26: Mudanças no uso da terra entre 2005 e 2015 (em ha) 194

Gráfico 27: Mudanças no uso da terra entre 1985 e 1995 (em ha) 198

Gráfico 28: Altura média de precipitações em Monteiro Lobato (em mm) 206

Gráfico 29: Altura média de precipitações em São José dos Campos (em mm) 207 


\section{Lista de Tabelas}

Tabela 1: Tabela de informações sobre Monteiro Lobato e São José dos 85 Campos.

Tabela 2: Índice de Avaliação Ambiental - IAA de Monteiro Lobato

Tabela 3: Carga orgânica poluidora de origem doméstica em Monteiro

Lobato

Tabela 4: Área ocupada da bacia hidrográfica: resultado da classificação 89 (em \%)

Tabela 5: Número de segmentos de canais da Bacia Hidrográfica do Rio 109 Buquira (Monteiro Lobato - SP) na escala de 1:200.000

Tabela 6: Comprimento dos segmentos de canais $(\mathrm{km})$ da Bacia 111 Hidrográfica do Rio Buquira (Monteiro Lobato - SP)

Tabela 7: Densidade de drenagem da Bacia Hidrográfica do Rio Buquira 112 (Monteiro Lobato - SP) $\left(\mathrm{km} / \mathrm{km}^{2}\right)$

Tabela 8: Coeficiente de manutenção da Bacia Hidrográfica do Rio 113 Buquira (Monteiro Lobato - SP) $\left(\mathrm{m}^{2} / \mathrm{m}\right)$

Tabela 9: Análise da Potabilidade da água com as variáveis Ferro, pH, 115 Turbidez, Amônia, Oxigênio Dissolvido e Cloro

Tabela 10: Uso e cobertura da terra em 1985 129

Tabela 11: Uso e cobertura da terra em 1995 132

Tabela 12: Uso e cobertura da terra em 2005 135

Tabela 13: Uso e cobertura da terra em 2015 


\section{Lista de Quadros}

Quadro 1: Comparação dos mapas de ganhos e perdas na área da bacia 148 para a categoria Área construída

Quadro 2: Comparação dos mapas de ganhos e perdas na área da bacia para a categoria Pastagem

Quadro 3: Comparação dos mapas de ganhos e perdas na área da bacia 162 para a categoria Solo exposto

Quadro 4: Comparação dos mapas de ganhos e perdas na área da bacia 169 para a categoria Reflorestamento

Quadro 5: Comparação dos mapas de ganhos e perdas na área da bacia 178 para a categoria Floresta primária

Quadro 6: Comparação dos mapas de ganhos e perdas na área da bacia 185 para a categoria Vegetação secundária

Quadro 7: Comparação dos mapas de ganhos e perdas na área da bacia 192 para a categoria Água

Quadro 8: Ponderação para as classes de Susceptibilidade dos solos à 202 erosão 


\section{INTRODUÇÃO}

Apresenta-se nesta tese, os estudos de uso e cobertura da terra na Bacia Hidrográfica do Rio Buquira, o qual está localizado nos municípios de Monteiro Lobato e São José dos Campos (SP), tendo como proposta a comparação das séries históricas de 1985 a 2015, em um período total de 30 anos.

Partimos do pressuposto de que ao longo do tempo, ocorreram diversas transformações no meio natural e antrópico, decorrente de toda uma conjuntura histórica, econômica, social e cultural das épocas em questão. Desta forma, foi possível constatar as mudanças ocorridas e importantes de se quantificar, como a supressão de floresta primária para o estabelecimento de pastagens, o crescimento de áreas de reflorestamento, o aumento e o retrocesso de áreas urbanas nos anos mais recentes, a composição de novas áreas sobre solo exposto e a manutenção considerável de corpos d'água, em meio a transposições e canalizações.

É comum em bacias hidrográficas diversas que a vegetação apresente fortes quadros de degradação ao longo dos anos, considerando todo o processo predatório de ocupação humana. Entretanto, com o passar dos anos, observouse que a área de floresta primária esteve em constantes recomposições junto à vegetação secundária. Ao passo que, em um dado ano, a vegetação secundária crescia, logo transformara-se em floresta primária. Portanto, ao atestarmos que a bacia se manteve conservada ao longo dos anos - por mais que sofresse perdas - confirmamos nossa hipótese inicial. 
Para a identificação destas mudanças, foram utilizadas as ferramentas de geoprocessamento para a classificação das imagens de satélite Landsat dos anos de 1985, 1995, 2005 e 2015. Inicialmente utilizamos o ArcGis 10.4 para a confecção das cartas temáticas de uso e cobertura da terra e o software Idrisi versão Taiga, com o módulo Land Change Modeler (LCM), que identifica as mudanças temporais ocorridas nos diferentes períodos. Assim, obtivemos como produto os mapas de Ganhos e Perdas da terra, onde todas as categorias de uso e cobertura foram comparadas entre os anos estudados, e constatadas quais classes foram substituídas.

Este trabalho foi elaborado a partir das concepções metodológicas de Leal (1995) e Rodriguez (2010), sobre o estudo do meio físico e as intervenções do ser humano no uso da terra, notadamente próximo a rios, além da necessária avaliação ambiental.

Esta área de estudo destaca-se por uma extensa rede de drenagem com grande número de nascentes e cursos d'água, tendo como alarmante amplos problemas no mecanismo de escoamento (ocasionando pontos de inundação e alagamento em diversas áreas do município), a incidência de acidentes em áreas de risco e a presença de pontos de erosão ligados à presença da atividade agrícola, pisoteio do gado, ausência de cobertura vegetal, e também àquela relativa ao uso urbano da terra.

Os processos erosivos em áreas rurais são ocasionados onde há maior concentração do escoamento de águas pluviais, provenientes, muitas vezes, da falta de práticas conservacionistas dos próprios produtores rurais, e através do manejo inadequado do escoamento das águas nas estradas vicinais, onde o 
transporte de sedimentos para os cursos d'água podem acarretar no assoreamento.

A erosão nas áreas urbanas - uma das formas de uso da terra que mais acarretam alterações ambientais - inicialmente pode ser desencadeada no processo de parcelamento das terras, onde a camada superficial resistente à erosão é removida, expondo o solo frágil e sem proteção ao escoamento das águas pluviais. Com a posterior e crescente impermeabilização do solo, o aumento do fluxo superficial é favorecido, acelerando os processos erosivos ao longo do sistema viário.

Outra importante questão sobre os processos de transformação em uma bacia hidrográfica através de ações antrópicas é quanto à qualidade das águas e da vegetação. Estes tem ligação direta com as atividades desenvolvidas e são fundamentais para a manutenção do equilíbrio do ecossistema natural. Quando os processos produtivos na bacia são destrutivos, o reflexo negativo impactará neste sistema como um todo. Desta forma, é necessária uma nova perspectiva entre as relações do ser humano com a sociedade, onde ações de gestão, planejamento ambiental e manejo adequado do uso da terra são essenciais para reverter o quadro ambiental negativo na área da bacia.

Mateo Rodriguez (1994) menciona que o planejamento ambiental:

"é um ponto de partida para a tomada de decisões relativas à forma e intensidade em que se usa um território e cada uma de suas partes incluindo os assentamentos humanos $e$ as organizações sociais produtivas. Constitui, em si, um processo organizado de coleta de informações, de análise e reflexão sobre as potencialidade e limitações dos sistemas ambientais de um território. Isso servirá como base para definir as metas, os objetivos, as estratégias de uso, os projetos, as atividades e as ações, síntese de uma organização das atividades sociais e 
econômicas do espaço (RODRIGUEZ e SILVA, 2013, p. 133134).

A referida tese dividiu-se em quatro capítulos, sendo eles: I Fundamentação Teórica, onde são discutidos os temas que contribuem para a compreensão da área de estudo, bem como o processo histórico de uso e cobertura; II - Metodologia, onde é apresentada a sistematização de todo o processo desenvolvido nesta presente tese, com enfoque na documentação e ferramentas cartográficas, no mapeamento temático e a utilização do módulo LCM e na realização dos trabalhos de campo. III - Caracterização da bacia hidrográfica, contendo um inventário da área de estudo, bem como cartas temáticas ambientais da área e IV - Resultados, com a apresentação das cartas de uso da terra dos anos de 1985, 1995, 2005 e 2015 e sobreposição destas para a composição das cartas de ganho e perda de terra ao longo destes anos, bem como a apresentação da carta de predição do uso e cobertura para os próximos 30 anos a partir de 2015; e por fim, as considerações finais. 
CAPÍTULO I

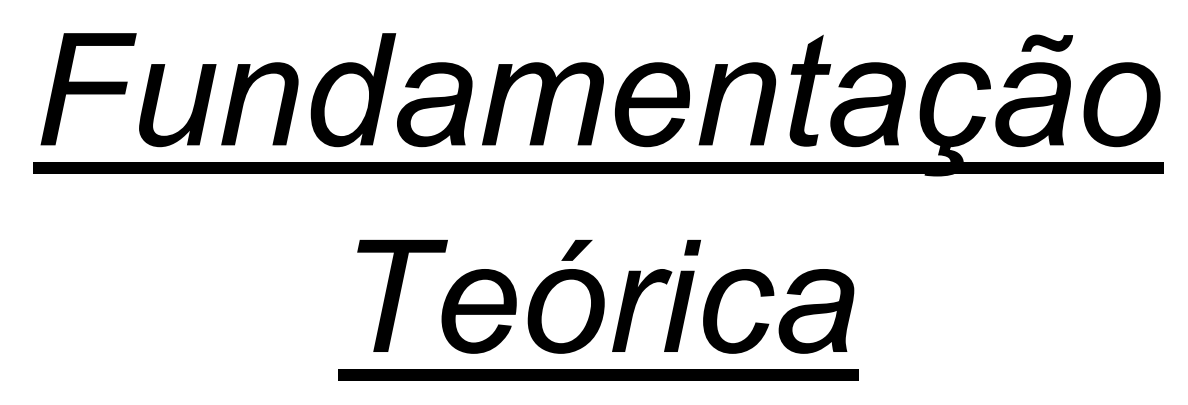




\subsection{A paisagem e o conceito de paisagem antropogênica}

Uma das categorias de análise que tem retomado a sua importância na ciência geográfica é da paisagem, formada por interações existentes entre os elementos naturais e pela mudança destes pela ação humana, marcada por profundas transformações que ocorreram ao longo de muitos anos na sua história de formação. Milton Santos (1997) afirma:

Cada tipo de paisagem é a reprodução de níveis de diferentes forças produtivas; a paisagem atende a funções sociais diferentes, por isso ela é sempre heterogênea; uma paisagem é uma escrita sobre a outra, é um conjunto de objetos que tem idades diferentes, é uma herança de muitos diferentes momentos; ela não é dada para sempre, é objeto de mudança, é um resultado de adições e subtrações sucessivas, é uma espécie de marca da história do trabalho, das técnicas, ela não mostra todos os dados, que nem sempre são visíveis (...). (SANTOS, 1997, p. 61)

Descrever os elementos naturais e humanos de uma paisagem somente

é possível considerando o ambiente como um conjunto geográfico que possui sua própria estrutura e funcionamento. Como afirmou Monbeig (1957), "a Geografia não é uma ciência de fatos isolados simples, passíveis de serem conhecidos por si e em si [...] é um erro comum e persistente pretender tomar e ensinar fatos geográficos isolados e atomizados". (MONBEIG, 1957, p. 12)

BERTRAND (1971) menciona que:

"[...] o resultado da combinação dinâmica, portanto instável, de elementos físicos, biológicos e antrópicos que, reagindo dialeticamente uns sobre os outros, fazem da paisagem um conjunto único e indissociável, em perpétua evolução" (BERTRAND, 1971, p. 2)

Para Guerra e Marçal (2014) 
A paisagem é a natureza integrada e deve ser compreendida como síntese dos aspectos físicos e sociais, sendo importante seu conhecimento, no sentido de serem desenvolvidas pesquisas aplicas que possam levar a metodologias que colaborem com o manejo adequado e sustentável dos recursos naturais, relevantes para a sociedade como um todo. (GUERRA E MARÇAL, 2014, p. 14)

De acordo com Corrêa (2011), a produção do espaço urbano:

(...) é consequência da ação de agentes sociais concretos, históricos, dotados de interesses, estratégias e práticas espaciais próprias, portadores de contradições e geradores de conflitos entre eles mesmos e com outros segmentos da sociedade. (CORREAA, 2011, p. 43)

Ao observar em detalhe o comportamento das paisagens, Cavalcanti (2014), menciona que:

(...) é possível perceber um ritmo periódico, como as mudanças que ocorrem ao longo de um dia ou em diferentes épocas do ano, que recebe o nome de funcionamento da paisagem. Quando acontece algo que provoca uma mudança completa do funcionamento de uma paisagem, diz-se que ela sofreu uma evolução. Um exemplo de ritmo paisagístico é aquele que relaciona a sazonalizade com a fenologia. (CAVALCANTI, 2014, p.20)

Assim, na cartografia de paisagens, é importante saber que além de um recorte espacial e temporal, o mapeamento vai além da "organização espacial (estrutura), mas também do funcionamento, evolução e planejamento das paisagens", (CAVALCANTI, 2014, p. 21) ao que consideramos como Geoecologia. 
Como a ação antrópica tem considerável potencial de modificação da natureza, através do uso e cobertura da terra, surge o conceito de paisagem antropogênica. Este emerge nos últimos anos para analisar a atividade na dimensão geográfica, sendo que é classificado como "o sistema natural produtivo composto por segmentos da Natureza levemente modificados e os sistemas tecnogênicos (paisagens antrópicas)" (MILKOV, 1973 apud RODRIGUEZ, 2010, p. 159).

A paisagem antropogênica é um fenômeno histórico e materializa a longa história da evolução do meio natural e as etapas históricas da economia e da sociedade e podem ser classificadas: a) segundo o tipo de atividade humana ou designação funcional (agrícolas, florestais, hídricas, industriais, urbanos); b) segundo a gênese (tecnogênicos, pastoris, de trabalho, etc.).

Para classificação das paisagens antropogênicas, Rodriguez et al (2010) elaborou uma representação, considerando o grau de transformações e modificações da paisagem e, que, dividem-se em categorias (figura 1): 
Figura 1: Classificação sintética das paisagens antropogênicas

\begin{tabular}{|c|c|c|c|c|}
\hline CATEGORIAS & $\begin{array}{l}\text { CLASSES (FORMAS DA } \\
\text { ATIVIDADE HUMANA) }\end{array}$ & TIPOS (UTILIZAÇÃO E OCUPAÇÃO) & $\begin{array}{l}\text { MUDANÇAS E INTENSIDADE DA } \\
\text { MODIFICAÇÃO (HEMEROBIA) }\end{array}$ & $\begin{array}{c}\text { COMPONENTES NATURAIS } \\
\text { AFETADOS PELA MODIFICAÇÃO }\end{array}$ \\
\hline \multirow{5}{*}{$\begin{array}{l}\text { NATURAIS E } \\
\text { SEMI- } \\
\text { NATURAIS }\end{array}$} & \multirow[t]{2}{*}{ Áreas naturais } & - Áreas naturais em uso funcional & \multirow{2}{*}{$\begin{array}{l}\text { Näo modificados ou levemente } \\
\text { modificados. }\end{array}$} & \multirow[t]{2}{*}{ Composição da atmosfera } \\
\hline & & $\begin{array}{l}\text { - Reservas, parques e diversos tipos de } \\
\text { áreas protegidas }\end{array}$ & & \\
\hline & \multirow{3}{*}{ Exploração Florestal } & - Bosques virgens e produtivos & \multirow{3}{*}{ Levemente modificada } & \multirow{3}{*}{$\begin{array}{l}\text { Cobertura vegetal e mundo } \\
\text { animal }\end{array}$} \\
\hline & & - Bosques e secundários & & \\
\hline & & - Plantações florestais & & \\
\hline \multirow{9}{*}{$\begin{array}{l}\text { ANTROPONAT } \\
\text { URAIS }\end{array}$} & \multirow{2}{*}{ Turística } & - Parques Recreativos & \multirow{2}{*}{ Modificação leve a moderada } & \multirow{5}{*}{ Microrelevo e microclima } \\
\hline & & - Zonas Turísticas & & \\
\hline & \multirow{3}{*}{ Pastoril } & - Pastos naturais & \multirow{3}{*}{ Modificação moderada a forte } & \\
\hline & & - Pastos herbáceo-arbustivo & & \\
\hline & & - Pastos artificiais (melhorados) & & \\
\hline & \multirow{4}{*}{ Agrícola } & - Plantações arbóreas perenes & \multirow{3}{*}{ Modificação forte a muito forte } & \multirow{4}{*}{$\begin{array}{l}\text { Solos, águas superficiais e } \\
\text { subterrâneas }\end{array}$} \\
\hline & & $\begin{array}{l}\text { - Campos e focos agrícolas de } \\
\text { subsistência }\end{array}$ & & \\
\hline & & - Plantaçöes agrícolas de sequeiro & & \\
\hline & & $\begin{array}{l}\text { - Plantações agrícolas irrigadas ou } \\
\text { dissecadas }\end{array}$ & $\begin{array}{l}\text { Modificação forte e } \\
\text { transformação artificial }\end{array}$ & \\
\hline \multirow{6}{*}{ ANTRÓPICAS } & \multirow{2}{*}{ Urbana } & - Cidades intermediárias ou grandes & \multirow{6}{*}{$\begin{array}{l}\text { Artificialização e transformação } \\
\text { antopogência }\end{array}$} & \multirow{6}{*}{$\begin{array}{c}\text { Estrutura geológica, mesorelevo } \\
\text { e mesoclima }\end{array}$} \\
\hline & & - Povoados e vilas rurais & & \\
\hline & Minor inductri & $\begin{array}{l}\text { - Áreas de exploração de jazidas } \\
\text { minerais }\end{array}$ & & \\
\hline & Minero-industrial & $\begin{array}{l}\text { - Áreas industriais, de armazéns e } \\
\text { portos }\end{array}$ & & \\
\hline & \multirow{2}{*}{$\begin{array}{l}\text { Exploração de recursos } \\
\text { hídricos }\end{array}$} & - Reservatórios pequenos e canais & & \\
\hline & & - Grandes barragens & & \\
\hline
\end{tabular}

Fonte: RODRIGUEZ (2010, p. 165)

Onde configuram-se como paisagens naturais e semi-naturais as que não sofreram modificações ou que foram levemente modificadas, paisagem antroponaturais que passaram por transformações e as paisagens antrópicas, nas quais as mudanças foram além dos biocomponentes, ou seja, modificaram também o relevo, o embasamento geológico.

\subsection{Uso e cobertura da terra e interações antrópicas}

O estudo sobre o uso e cobertura da terra emerge da relação ser humano-sociedade e suas potenciais funções dentro do sistema. 
Segundo o Instituto Brasileiro de Geografia e Estatística (IBGE), (2006), o uso da terra diz respeito à "uma representação sintética de um conjunto de atividades econômicas com expressão espacial que, de alguma forma, interage nesse espaço" (IBGE, 2006, sem paginação).

A cobertura da terra, por sua vez, indica "áreas onde predominam as características naturais ou construídas/produzidas" (IBGE, 2006, sem paginação).

Geralmente, estes dois conceitos são utilizados, ligados às atividades humanas, onde se relacionam ao tipo de revestimento do solo, seja ele florestal, agrícola, residencial ou industrial. A cobertura pode ser interpretada através de dados de sensoriamento remoto, a partir de "modelos, tonalidades, texturas, formas, arranjos espaciais das atividades e localização do terreno." (IBGE, 2006, s. p.)

A Figura 2 apresenta as classes de uso e cobertura da terra proposto pelo IBGE (2006), sendo o nível I as principais categorias da cobertura terrestre do planeta e o nível II o uso e cobertura em nível regional: 
Figura 2: Etapas de levantamento e classificação do uso e cobertura da terra Níveis I e II (IBGE, 2006)

\begin{tabular}{|c|c|c|}
\hline NIVEL I & & NIVEL II \\
\hline \multirow{2}{*}{$\begin{array}{l}\text { 1. Äreas Antrópicas } \\
\text { Näo Agricolas }\end{array}$} & 1.1 & Área Urbanizada \\
\hline & 12 & Àrea de Mineraçäo \\
\hline \multirow{5}{*}{$\begin{array}{l}\text { 2. Áreas Antrópicas } \\
\text { Agricolas }\end{array}$} & 2.1 & Cultura Temporária \\
\hline & 2.2 & Cultura Permanente \\
\hline & 2.3 & Pastagem \\
\hline & 2.4 & Silvicultura \\
\hline & 2.5 & Uso Não Identificado \\
\hline \multirow{2}{*}{$\begin{array}{l}\text { 3. Áreas de } \\
\text { Vegetaçāo Natural }\end{array}$} & 31 & Florestal \\
\hline & 3.2 & Campestre \\
\hline \multirow{2}{*}{ 4. Água } & 4.1 & Corpo d'Água Continental \\
\hline & 4.2 & Corpo d'Água Costeiro \\
\hline 5. Outras Áreas & 5.1 & Ärea Descoberta \\
\hline
\end{tabular}

Fonte: IBGE (2006). Adaptado por autora.

O nível III, não descrito nesta tabela, explicita o uso do solo propriamente dito.

Esta nomenclatura possibilita a identificação e descrição da cobertura e do uso da terra, e também, a comparação dos diversos usos da terra em todo Território.

Segundo Mota (2011) para definição dos usos do solo deve-se considerar: 
1. As compatibilidades dos usos; 2. As características do meio, sua importância do ponto de vista ecológico, paisagístico, arqueológico ou histórico-cultural; 3. A topografia do terreno; 4 . As áreas a preservar ou de uso restrito; 5 . A qualidade ambiental existente, capacidade do meio de receber novas cargas poluidoras; 6 . Os usos poluidores em relação aos demais usos; 7. A capacidade do meio de dispersar e depurar poluentes; 8. A infraestrutura sanitária existente ou projetada; 9. As condições do solo para o uso de soluções individuais de saneamento (poços e fossas), nível do lençol freático, capacidade de absorção do solo; 10 . A qualidade ambiental desejável, padrões de qualidade já definidos ou propostos, enquadramento proposto para os recursos hídricos; 11. As relações entre as características ambientais e os aspectos sociais, econômicos, culturais e políticos. (MOTA, 2011, p.305)

As áreas urbanas e industriais são as que necessitam de maior atenção, pois seu funcionamento e transformação acarretam consideráveis e extensas alterações do meio físico. Considerando que a população urbana brasileira é de aproximadamente 85\% (IBGE, 2010), os impactos do uso e cobertura nas áreas urbanas adquirem maior relevância. Segundo Nakazawa, 1994:

A ocupação urbana sem critérios leva ao desencadeamento de escorregamentos, à erosão das áreas desprotegidas, à concentração - e muitas vezes prejudicial - de águas pluviais, à poluição das águas e do solo (devido à disposição inadequada de resíduos sólidos e líquidos, como lixos entulhos e águas servidas), ao assoreamento intenso e às inundações das regiões de baixada etc. (NAKAZAWA, 1994, p. 8)

Outra consideração sobre a ampliação das áreas urbanizadas, diz respeito à construção de áreas impermeabilizadas, que, de acordo com Christofoletti (2015):

(...) repercute na capacidade de infiltração das águas no solo, favorecendo o escoamento superficial, a concentração das enxurradas e a ocorrência de ondas de cheia. A urbanização afeta o funcionamento do ciclo hidrológico, pois interfere no rearranjo dos armazenamentos e na trajetória das águas. (...) 
Outros impactos diretos, em virtude da obras de urbanização, nas características geomorfológicas, referem-se à mudanças nas condições do sítio urbano, através de aterros, terraplanagens, retificações de canais, etc. (CHRISTOFOLETTI, 2015, p. 424)

O uso e cobertura inadequado em ambiente rural causa prejuízos ao solo e aos recursos hídricos, acelerando os processos erosivos e reduzindo a qualidade e a quantidade de água. De acordo com Zoccal (2007):

O processo de ocupação do solo, atualmente equivocado e sem as mínimas condições técnicas, levou à substituição quase total da vegetação primitiva, dando lugar a culturas de ciclo curto. $O$ constante revolvimento do solo sem tecnologia adequada resultou no maior problema da prática agrícola, a erosão hídrica, que comprometeu os recursos naturais, pondo em risco a produção econômica, pela degradação dos solos e assoreamento dos mananciais que influenciam na qualidade $e$ disponibilidade da água. (ZOCCAL, 2007, p.11)

Em muitas situações, falta aos proprietários da terra a preocupação com os danos ambientais possíveis; em outros casos, a ausência de conservação e adequação das estradas rurais é a precursora do carreamento do solo para os mananciais.

O aumento da pressão das atividades antrópicas sobre os recursos naturais, com a consequente intensificação dos "riscos ou acidentes" gera a necessidade de avaliar a amplitude e as consequências da interferência humana nos sistemas naturais (MOROZ - CACCIA GOUVEIA, 2010).

A importância de se analisar a morfologia original e a morfologia antropogênica nas superfícies urbanas, para a compreensão de diversos processos hidro-geomorfológicos atuais, condiz em representar as formas de 
antes, durante e após a urbanização, identificando as unidades geomorfológicas que estão mais preservadas ou mais degradadas ao longo do tempo da expansão urbana.

Não se pode negar a periodização em que ocorreu determinado uso e cobertura, pois estes são distintos em cada momento histórico, e estas revelam singularidades relacionadas em sua evolução e seguem princípios em comum. É necessário compreender a dinâmica das variáveis, onde sempre estão atreladas à uma situação e a uma data.

\subsection{Manejo integrado de bacias hidrográficas e planejamento do uso do solo urbano e rural}

De acordo com Souza e Fernandes (2000), o manejo integrado de bacias hidrográficas tem o objetivo de:

(...) tornar compatível produção com preservação/conservação ambiental, buscando adequar a interferência antrópica às características biofísicas dessas unidades naturais (ordenamento do uso/ocupação da paisagem, observadas as aptidões de cada segmento e sua distribuição espacial na respectiva bacia hidrográfica), sob gestão integrativa e participativa, de forma que sejam minimizados impactos negativos e se garanta o desenvolvimento sustentado (SOUZA e FERNANDES, 2000, p. 62)

Sendo assim, o manejo integrado considera uma visão conjunta da ação antrópica sobre a bacia e emprega uma gama de práticas e técnicas não isoladas para a preservação e conservação desta, configurado como uma forma de 
planejamento em busca do desenvolvimento sustentável.

Para Santos (2004), o Planejamento ambiental urbano e rural contempla:

\section{(figura 3)}

Figura 3 - Fases do Planejamento Ambiental

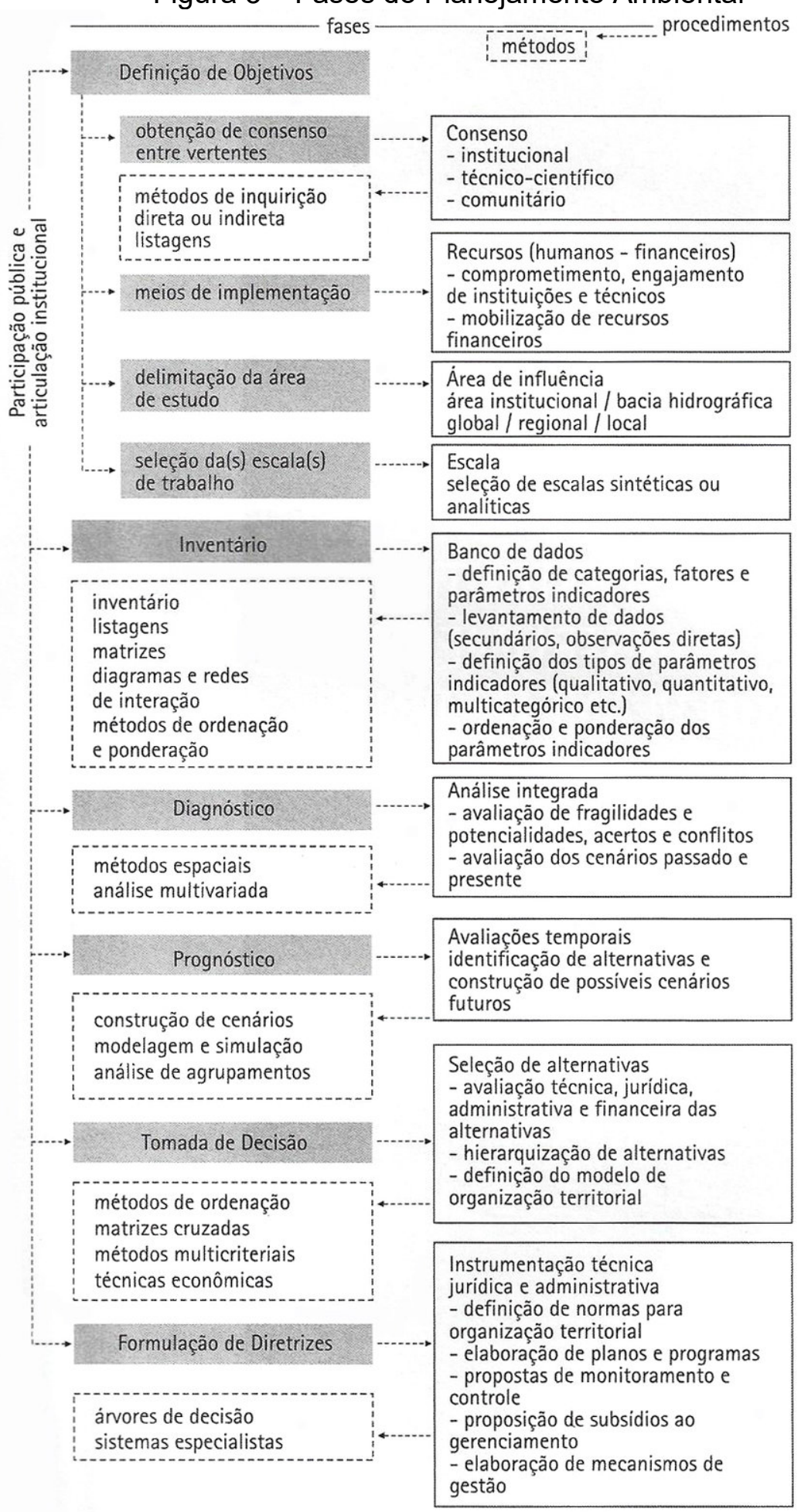


Fonte: (SANTOS, 2004)

Na perspectiva de Santos (2004), o Planejamento ambiental é dividido nas seguintes fases: 1. Definição dos Objetivos; 2. Inventário; 3. Diagnóstico; 4. Prognóstico; 5. Tomada de Decisão e 6. Formulação de Diretrizes. Onde, na fase da Definição dos objetivos, haveria a participação pública e uma articulação institucional inerente.

A adoção da bacia hidrográfica como unidade de planejamento, já implementada pela Lei paulista de recursos hídricos $n^{\circ} 7.663$, de $1991^{1}$, segundo LEAL (2003), está na capacidade desta em abordar todos os seus elementos (água, solo, flora, fauna, uso e ocupação do solo, etc.) e compreendê-la como uma totalidade composta por elementos naturais e sociais, inter-relacionados e dinâmicos" (LEAL, 2003, p. 71).

Segundo Finkler (2013), entre as ferramentas para organização e disciplinamento das bacias hidrográficas urbanas destacam-se: "planos diretores municipais, geração de recursos para as ações de manutenção dos sistemas de controle de drenagem urbana e as ações em saneamento". (FINKLER, 2013, p.48).

Sendo, o Plano Diretor "um instrumento básico da política de desenvolvimento e expansão urbana e parte integrante do processo de planejamento municipal" (BRASIL, 2001), tendo o zoneamento urbano como um dos instrumentos para "controlar o uso e a ocupação do espaço urbano. 0 zoneamento urbano divide a cidade em áreas sobre as quais incidem diretrizes

\footnotetext{
${ }^{1}$ Lei $n^{\circ} 7.663$, de 30/12/1991 - Estabelece normas de orientação à Política Estadual de Recursos Hídricos bem como ao Sistema Integrado de Gerenciamento de Recursos Hídricos, em nível estadual.
} 
diferenciadas para o uso e a ocupação do solo". (TÔSTO, 2014, p. 221)

A geração de recursos para as ações de manutenção dos sistemas de controle de drenagem urbana condiz com a captação de recursos para as compensações ambientais, como a cobrança pelo uso da água, por exemplo.

E, por fim, as ações de saneamento, considerando a Lei $n^{\circ} 11.445$ (BRASIL, 2007), referem-se às seguintes atividades e infraestruturas: 1. Abastecimento de água potável; 2. Esgotamento sanitário; 3. Limpeza urbana e manejo de resíduos sólidos e 4. Drenagem e manejo das águas pluviais urbanas.

Para o planejamento e uso do solo rural, Christofoletti (2015) aponta que, há a importância do ajustamento e adequação às gradações das variáveis topográficas ao buscar a implantação de atividades agropastoris. Indica que a elaboração da carta de declividades das vertentes, combinada com as informações sobre os talhes das formas interfluviais, são essenciais para se avaliar as restrições à mecanização e escolha de técnicas para a conservação dos solos.

Segundo Chistofoletti (2015), o conhecimento sobre os processos geomorfológicos são de suma importância, no que tange:

(...) reconhecer a incidência espacial dos processos e as suas intensidades e mudanças ao longo das vertentes. Para o controle da erosão dos solos e do escoamento superficial, nas vertentes, torna-se oportuno fazer uma alocação das culturas desde o topo até o sopé, assim como realizar obras costumeiramente indicadas pelos especialistas para o manejo do solo. O mapeamento dos locais e áreas de risco morfogenéticos representa instrumento para se avaliar o uso agrícola e a aplicação das técnicas de contenção dos movimentos de massa. Outra abordagem consiste em discernir as unidade morfodinâmicas da paisagem, estabelecendo a conexão entre topografias e morfodinâmica. (CHRISTOFOLETTI, 2015, p. 420) 
Quanto ao escoamento das águas superficiais, a urbanização tem caráter determinante, culminando em danos diretos à população (figura 4):

(Figura 4) - Diagrama de interação indicando as consequências do processo de urbanização sobre os processos de escoamento das águas superficiais.

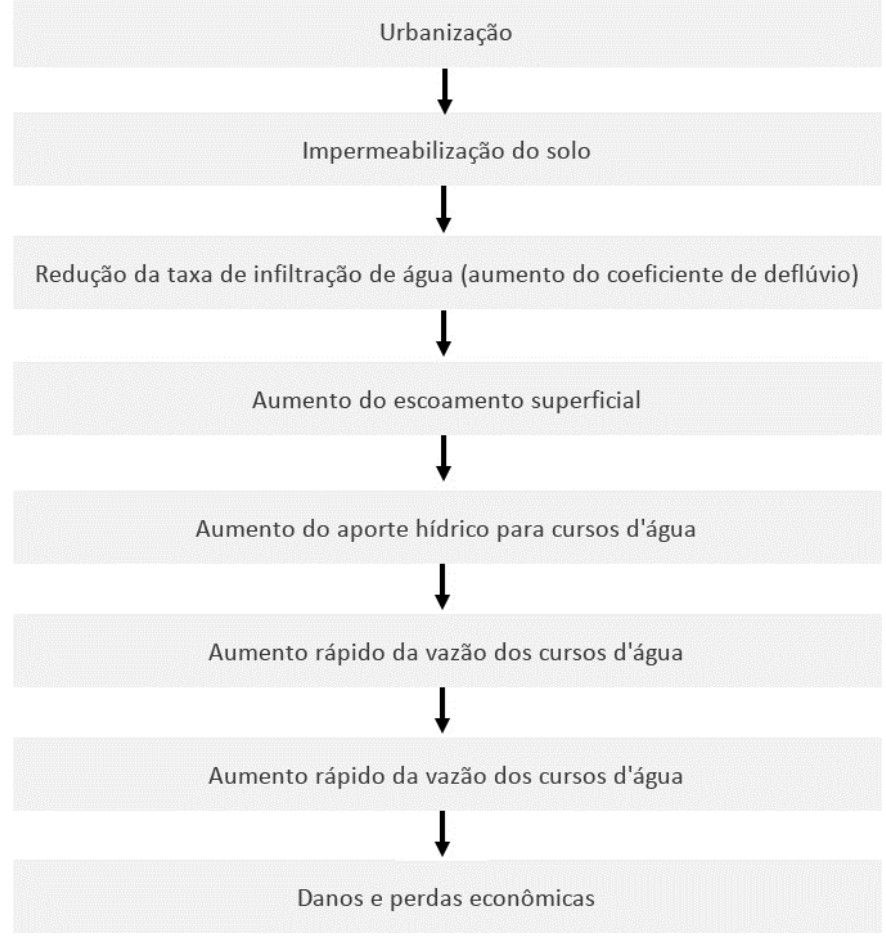

Fonte: Sanchez (2006)

Para a diminuição dos impactos causados pelos processos em conflito com o manejo sustentável, um programa de recuperação de áreas seria importante para minimizar ou eliminar os efeitos adversos no meio ambiente. Para Sánchez (2006), a recuperação ambiental é "o resultado da aplicação de técnicas de manejo visando tornar uma área degradada apta para um novo uso produtivo", sendo que o "novo uso poderá ser igual ou diferente do uso que precedeu a ação degradadora a conservação ambiental (uso indireto)" (SANCHEZ, 2006, p. 34).

\subsection{Perigo, Vulnerabilidade e Riscos ambientais}


A ocorrência de fenômenos naturais extremos tem se mostrado cada vez mais frequentes, tendo em vista as interferências antrópicas no meio natural.

Segundo Nunes (2015) o risco de desastres tem sido exacerbado por práticas que desconsideram as características físicas dos locais, sendo que dois processos sociais contemporâneos se destacam quanto as suas capacidades de alterar rapidamente o ambiente natural: a urbanização e a globalização.

O estudo do risco ambiental é composto por dois principais conceitos: o perigo e a vulnerabilidade.

O perigo ou hazards são os desencadeadores dos desastres naturais que resultam em impactos na população humana (NUNES, 2015). Podem ser configurados como os extremos de temperatura, tempestades, abalos sísmicos e vulcanismo.

Como exemplo dos impactos dos hazards, citamos as secas, os incêndios, as inundações, os movimentos de massa e as epidemias.

Voltamos a atenção para as inundações e movimentos de massa, aos quais estão presentes na Bacia hidrográfica em estudo e, assim, Nunes (2015) define que as inundações são:

(...) determinadas por combinações de feições atmosféricas, topografia, características das bacias hidrográficas e uso da terra, aspectos que se alteram em importância ao longo do tempo, dado o dinamismo dos elementos físicos e, principalmente, da sociedade. (NUNES, 2015, p.22) 
A autora atenta ao fato de que estas se associam a grandes perdas econômicas, e a óbitos, por impossibilitarem práticas agrícolas e ainda, a proliferação de doenças como a dengue.

Nunes (2015) alerta, entretanto, que muitos locais em que as inundações ocorrem frequentemente não tem apresentado um aumento proporcional de precipitações, levando a crer que "as mudanças nos ambientes impressas pelas atividades humanas tem contribuído sobremaneira para a maior frequência e magnitude dos eventos, bem como prejuízos associados". (NUNES, 2015, p.22)

Os movimentos de massa, por sua vez,

(...) acontecem quando a tensão de cisalhamento (força que promove o movimento nas encostas) é excedida, de modo que material intemperizado ou não é conduzido abaixo, envolvendo massas de solo e, eventualmente, material rochoso. Os movimentos de massa podem ser secos ou úmidos, englobando quedas de blocos, deslizamentos, rastejos, avalanches e subsidências. (NUNES, 2015, p. 23)

A autora menciona que além de serem processos comuns, aliados aos taludes naturais induzidos pela ação da gravidade e água, podem também ser causas das ações humanas que desestabilizam o equilíbrio das encostas.

Nunes (2015) ressalta que a ocupação desenfreada de encostas, especialmente em meio tropical úmido é um forte contribuinte para o aparecimento dos movimentos de massa, e que, muitas vezes, as precipitações são apenas deflagradoras dessas ocorrências.

Para Medeiros e Souza (2016), a vulnerabilidade ambiental: 
Refere-se ao conjunto integrado de fatores ambientais (ecológicos e biológicos) que diante de atividades humanas, ocorrentes ou que venham se manifestar, poderá sofrer alterações afetando, total ou parcialmente, a estabilidade ecológica de um local." (MEDEIROS E SOUZA, 2016, p.57)

A vulnerabilidade considera, portanto, a capacidade de um indivíduo ou grupo social de dar uma resposta à ocorrência de um desastre natural, sendo, assim um dos componentes do estudo dos riscos ambientais.

Para Nunes (2015), vulnerabilidade é:

A capacidade de antecipar, fazer frente a, resistir e se recuperar de um impactos, esta última refletida pela resiliência, que é o nível de mudança que um sistema pode suportar em alterar seu estado, revelando sua capacidade de se restabelecer e ainda melhorar sua reatividade perante ocorrências similares futuras. (NUNES, 2015, p.14)

Figueiredo (1994) define áreas de risco como aquelas sujeitas às ocorrências de fenômenos de natureza geologia-geotécnica e hidráulica que impliquem na possiblidade de perda de vidas e ou danos materiais. Esses locais são, predominantemente, ocupações de fundo de vales sujeitos a inundações e solapamento, ou encostas passíveis de escorregamentos e desmoronamentos devidos às altas declividades.

O risco é o produto entre o perigo e a vulnerabilidade, resultante de quando há uma situação de ameaça natural, social, entre outros, sobre uma população vulnerável.

Rosa Filho (2008) pondera que há duas denominações quanto ao risco: 
O risco atual corresponde ao risco instalado em áreas ocupadas e aponta os locais que devem receber prioritariamente as medidas estruturais e não-estruturais voltadas à redução desses riscos. O risco potencial caracteriza os terrenos quanto à sua suscetibilidade para geração de novas situações de risco em áreas ainda não intensamente ocupadas, fornecendo subsídios para a expansão e o adensamento das diferentes formas de uso do solo (ROSA FILHO, 2008, p. 83).

Para a redução do perigo ou da vulnerabilidade, atrelado a uma melhor convivência com os riscos, é realizado diferentes tipos de ajustamentos, que são respostas de curto prazo, adotadas de forma incidental ou de forma proposital. (SOUZA, 2008)

De acordo com Souza (2008):

As melhorias urbanísticas e a existência de serviços e equipamentos urbanos básicos podem ser entendidas como formas de ajustamento incidental, uma vez que podem surtir efeitos sobre a redução da vulnerabilidade frente aos incidentes, embora esta não seja sua função primordial (SOUZA, 2008, p.94).

No caso de escorregamentos, por exemplo, ajustamentos seriam a construção de moradias mais reforçadas, a manutenção de vegetação nas encostas e a drenagem das águas pluviais. (SOUZA in GERARDI, 2008).

\subsection{0 contexto da bacia do Rio Buquira no Vale do Paraíba}

A cidade de Monteiro Lobato, que surgiu como "núcleo espontâneo de povoamento" (MÜLLER, 1969, p. 33), elevada à categoria de cidade em 1953, 
(MÜLLER, 1969, p. 39) ao longo da segunda metade do século XX, caracterizouse por ser um pequeno "núcleo" ou "centro" populacional, "sub-urbanizada", segundo a mesma autora. (MÜLLER, 1969, p. 10)

O fato de Monteiro Lobato ser "sub-urbanizada" não retirou da cidade o atrativo de ser contexto de várias pesquisas no século XXI. Para Issa (2003),

Seguindo uma tendência mundial atual, a população do município de Monteiro Lobato tem encarado o turismo como a solução para todos os problemas e a cura de todos os males. Solução de todos os problemas como possibilidade de desenvolvimento econômico e geração de emprego. Cura de todos os males como possibilidade de aumento da autoestima, valorização da cultura local e recuperação ambiental. (ISSA, 2003, p. 2)

Um dos elementos da natureza mais atrativos para uma determinada localidade atrair turistas é a existência de recursos tais como os rios. A Tese de Doutorado de Pivott (2014), também enfatizou esta questão do Buquira como atrativo do fomento do turismo local:

O Turismo, inserido no setor terciário da economia, o da prestação de serviços, promove atividades geradoras de trabalho e renda, representando uma atividade econômica complementar para pequenos municípios com potencial turístico e com limitações para desenvolver os setores primário e secundário. A atividade turística recebe críticas quanto a aspectos destrutivos do consumo e produção e do Turismo de Massa e por, também, cumprir função pró-capitalista. (PIVOTT, 2014, p.8)

Müller (1969, p. 350) comenta: 
(...) o problema dos pequenos centros, heranças de um passado, que, nas condições atuais, não encontram clima de desenvolvimento, cuja revitalização exigiria um amplo plano de ação, interessando a áreas extra-regionais, pela revalorização das vias transversais de circulação. Evidentemente, não se pode esperar que todos eles se transformem em grandes centros; afinal, centros locais são importantes, pelas funções que preenchem em relação ao meio rural. No entanto, uma forma de reerguimento econômico viria propiciar-lhes melhores condições para seu reequipamento, dando-lhes um mínimo de serviços para atendimento satisfatório, nos setores básicos, de sua própria população e da área de que são centro (...) (MÜLLER, 1969, p. 350)

Se o turismo, muitas vezes, é visto como a "salvação" econômica da cidade, é importante e prudente que a aplicação especializada de ferramentas de geoprocessamento não esteja necessariamente alinhada tão somente a esta política de fomento do turismo, e sim para um conhecimento e preservação do solo situado próximo a áreas que, muitas vezes, são dadas como próprias para o turismo, o que é um recorte especial que realizaremos em nosso trabalho.

No caso de São José dos Campos, as áreas próximas à foz do Rio Buquira são densamente povoadas.

De acordo com Saraceni e Furlan (2012)

São José dos Campos traz em seu nome uma das características principais da sua paisagem: os campos naturais. A cidade se distribui ao redor do rio Paraíba do Sul e da rodovia Presidente Dutra. Outros núcleos urbanos também se formaram nas proximidades e tornaram-se distritos: São Francisco Xavier e Eugênio de Melo. O primeiro com características mais rurais; o segundo, urbanas. O município destaca-se pelas indústrias dos setores, aeroespacial, de telecomunicações e automotivo. Importantes institutos de pesquisa também estão presentes e contribuem para tornar o município um polo cientifico e tecnológico. (SARACENI e FURLAN, 2012, p. 48) 
São José dos Campos, cidade que no início do século XX era um centro de tratamento de tuberculosos, a partir de 1921 passou a ser um local atrativo para indústrias dos mais variados ramos, atribuindo à cidade o status atual de cidade industrial:

\begin{abstract}
A Lei de Incentivos joseense de 1952, aliada a uma conjuntura econômica nacional favorável ao investimento de capitais em indústrias, possibilitou à cidade [de São José dos Campos] ser vista como terreno atrativo para novas instalações. Havia a necessidade, para os capitalistas, de procurarem terrenos, incentivos fiscais, farta disponibilidade de água e energia elétrica e existência de mão-de-obra altamente especializada em cidades que estivessem no eixo São Paulo/Rio. São José dos Campos oferecia essas condições. (PEREIRA, 2009, p. 177)
\end{abstract}

Assim, realizar o mapeamento histórico do uso da terra em Monteiro Lobato e São José dos Campos será um elemento precioso para identificarmos que, justamente, as regiões próximas ao rio Buquira, que, no caso de Monteiro Lobato, poderiam ser utilizadas como um atrativo natural para o fomento do turismo local são, muitas vezes, as mais degradadas.

A Bacia do Rio Buquira faz parte da Bacia Hidrográfica do Rio Paraíba do Sul (Unidade de Gerenciamento de Recursos Hídricos - UGRHI - 02), que banha os estados de São Paulo, Rio de Janeiro e Minas Gerais. O Rio Paraíba do Sul percorre cerca de $1150 \mathrm{~km}$ a partir da nascente na Serra da Bocaina (SP) até sua foz, no município de São João da Barra (RJ).

O Rio Paraíba do Sul percorre a porção do território do Vale do Paraíba importante região socioeconômica, de eixo urbano seguindo o traçado da Rodovia Presidente Dutra. 
Historicamente, o processo de desenvolvimento do Vale do Paraíba é devido a uma soma de fatores, cujo mais importantes são: "a posição do Vale do Paraíba, seu sistema viário e o sistema industrial da região Centro-Sul do país." (CODIVAP, 1971, p. 307). Nesta região, encontram-se alguns centros urbanos de valia, considerados como centro de dispersão de cultura e fluxos econômicos, a contar os municípios de São José dos Campos e Taubaté.

O Vale do Paraíba, ainda, destaca-se devido a seus recursos naturais e recursos construídos, possuindo atrações turísticas, como: "áreas climáticas, paisagísticas, recursos hidrominerais, áreas pesqueiras, de monumentos históricos e artísticos, centros urbano-industriais, áreas de represa, centros religiosos, elementos de folclore e artesanato e organizações de fins culturais". (CODIVAP, 1971, p. 308).

Segundo Saraceni e Furlan (2012), o Vale do Paraíba é

(...) uma extensa bacia hidrográfica assentada sobre rochas sedimentares - formadas pela deposição de sedimentos vindos das áreas mais altas do entorno. A erosão em terrenos cristalinos entre a planície e a Serra do Mar criou um relevo chamado de "mar de morros". (SARACENI e FURLAN, 2012, p. 59)

Para o Vale do Paraíba foram realizados distintos trabalhos de planejamento regional que avaliaram a evolução e a dinâmica da paisagem, destacando-se o Consórcio de Desenvolvimento Integrado do Vale do Paraíba (CODIVAP), desenvolvido em 1971, o Plano Regional do Macro-eixo Paulista, em 1978 e o Macrozoneamento do Vale do Paraíba e Litoral Norte (MAVALE), na década de 90 . 


\subsection{São José dos Campos: história e desenvolvimento econômico}

São José dos Campos foi criada como um aldeamento indígena pela ação dos padres jesuítas, "no alto do Rio Comprido", ${ }^{2}$ um dos afluentes do Rio Paraíba do Sul, no Vale do Paraíba paulista. Segundo o cronista e historiador Jairo César de Siqueira, "a data mais remota citando nossas origens é de 1643, quando os padres [jesuítas] requereram e objetivaram para os índios uma sesmaria onde deveriam ser os guaianás nômades agrupados, na proteção contra sua caça e escravidão $(\ldots)^{\prime 3}{ }^{3}$

A geógrafa Nice Lecocq Müller ressalta que as povoações do Vale do Paraíba surgiram, como regra geral, como núcleos originados a partir das vias de circulação então percorridas. ${ }^{4}$ Foi elevada a município em 27 de julho de 1767, com o nome de São José do Paraíba, ${ }^{5}$ e como cidade em 22 de abril de 1864, pela Lei Provincial n. ${ }^{\circ} 27$. Em 1871, pela Lei n. ${ }^{\circ} 47$, de 2 de abril de 1871, passou a ser denominada como "São José dos Campos", "em atenção a seu aspecto topográfico", 6 e, nas palavras da engenheira florestal Klécia Massi, "o município não se chama São José dos Campos à toa. Esses campos são os campos cerrados que existiam aqui. (...) Tem espécies aqui que não são

\footnotetext{
2 IBGE. Enciclopédia dos Municípios Brasileiros. XXX volume, p. 192. In:

$<$ https://biblioteca.ibge.gov.br/biblioteca-catalogo?view=detalhes\&id=227295> Acesso em: 06 jul. 2018.

${ }^{3}$ SIQUEIRA, Jairo César de. Nossa cidade de São José dos Campos. São José dos Campos: Fundação Cassiano Ricardo, 1991 , p. 50.

${ }^{4}$ MÜLLER, Nice Lecocq. O fato urbano na bacia do Paraíba - São Paulo. Rio de Janeiro: Fundação IBGE, 1969 , p. 25.

${ }^{5}$ IBGE. Enciclopédia dos Municípios Brasileiros. XXX volume, p. 193. In:

$<$ https://biblioteca.ibge.gov.br/biblioteca-catalogo?view=detalhes\&id=227295> Acesso em: 06 jul. 2018.

${ }^{6}$ IBGE. Enciclopédia dos Municípios Brasileiros. XXX volume, p. 193. In:

$<$ https://biblioteca.ibge.gov.br/biblioteca-catalogo?view=detalhes\&id=227295> Acesso em: 06 jul. 2018
} 
encontradas em nenhuma outra área do Brasil. Tem uma importância histórica e biológica $(\ldots){ }^{\prime \prime}{ }^{7}$

A história de São José dos Campos é tradicionalmente dividida em "tempos", seguindo a descrição de uma matriz de ordem econômica. Estes seriam: o café, o algodão, dos sanatórios e das indústrias na cidade.$^{8} \mathrm{O}$ brasão joseense (figura 5), oficializado pela Lei Municipal n. ${ }^{\circ} 180$ de 1926 , criado por Afonso d’Escragnolle Taunay e José Wasth Rodrigues, ressaltava no "listão" os bons ares locais: "AURA TERRAQUE GENEROSA", ou seja, "generosos são meus ares e a minha terra". 9

Figura 5 - Brasão original de São José dos Campos, pintado por J. Wasth Rodrigues.

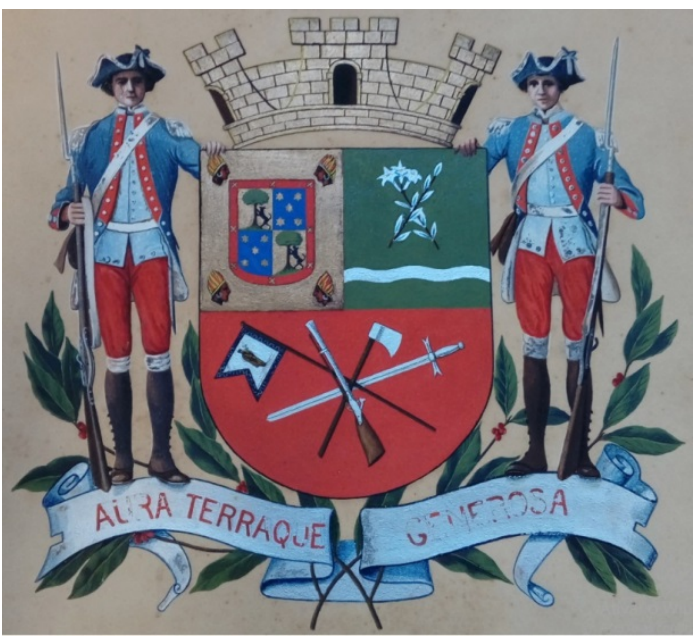

Fonte: Museu Paulista da USP, Coleção Wasth Rodrigues, Documento IC 10560, cjwr, A2Pr39Cx5.

Características geográficas de São José dos Campos foram enfatizadas por um articulista do jornal O Valeparaibano em 1972:

\footnotetext{
${ }^{7}$ Entrevista com Klécia Massi por CODAZZI, Julio. “Zoneamento: proposta é retrocesso ambiental, apontam especialistas". In: O VALE, 27/07/2019, p. 5

${ }^{8}$ BONDESAN, Altino. São José de ontem e de hoje. São José dos Campos: JAC Editora, 1996, p. 72.

${ }^{9}$ CÂMARA MUNICIPAL DE SÃO JOSÉ DOS CAMPOS. "Brasão de armas de São José foi desenhado em 1926 por dois historiadores". In: <https://www.youtube.com/watch?v=RQZq1wSITBc>. Acesso em: 06 jul. 2019.
} 
Possuindo boas terras para lavoura, excelente clima, rios auríferos, tornou-se caminho para as Minas Gerais e esse trânsito iniciou um núcleo comercial que haveria de perdurar (...) Uma atividade constante fez com que duas estradas passassem por aqui: as estradas São Paulo-Rio e São José-Campos do Jordão. ${ }^{10}$

O discurso da mídia jornalística sobre a cidade pode ser resumido como a seguir:

São José dos Campos tem vocação para o crescimento. Na história dos seus 252 anos, o município deixou de ser uma cidade de tuberculosos, na primeira metade do século passado, para tornar-se a capital brasileira do avião, polo industrial automobilístico e região de tecnologia e inovação. O desafio, agora, é usar desses meios para garantir o crescimento sustentável da cidade, aliando, na mesma medida, qualidade de vida, proteção ao meio ambiente e desenvolvimento econômico (ALVES, 2019). ${ }^{11}$

Na primeira metade do século 20 , o acesso mais rápido para São José dos Campos era a Estrada de Ferro Central do Brasil. Em 1951, foi inaugurada a Rodovia Presidente Dutra, para interligar as duas principais cidades brasileiras, fazendo de São José dos Campos um lugar privilegiado para investimentos industriais. Segundo o arquiteto Alexandre Penedo, a cidade foi "favorecida pela situação geográfica - oferta de terrenos planos - entre os dois grandes pólos (São Paulo e Rio de Janeiro)". ${ }^{12}$

No período citado, a cidade teve como duas de suas atividades econômicas a criação de uma estrutura para o tratamento de pessoas com

\footnotetext{
10 O VALEPARAIBANO. "Salve São José dos Campos no 205.o aniversário!", 27/07/1972, p. 1.

${ }^{11}$ ALVES, Xandu. "São José planeja futuro com foco na inovação e mobilidade urbana". In: O VALE, 27/07/2019, p. 2.

12 PENEDO, Alexandre. Arquitetura moderna: São José dos Campos. São José dos Campos: A. Penedo, 1997, p. 24.
} 
tuberculose, sendo que a primeira fábrica de porte que se instalou na cidade foi a "Fábrica de Louças Santo Eugênio", inaugurada em 1921. Embora fábricas como a "Tecelagem Parahyba", inaugurada em 1928, e a "Rhodosá de Rayon" (1947) passassem a fazer parte da paisagem de São José dos Campos, isso não impediu que esta fosse transformada em uma "Estância Climatérica e de Repouso" pelo Decreto Estadual n. ${ }^{\circ} 7007$, de 12 de março de 1935, e anos mais tarde em uma "Estância Hidromineral Natural", pela Lei Estadual n. ${ }^{0}$ 1, de 18 de setembro de $1947 .^{13}$

Em 18 de abril de 1933, os poderes Executivo e Legislativo de São José dos Campos promulgaram o Ato de número 110, que dividia a cidade em quatro zonas: a industrial, residencial, a comercial e a sanatorial. Tal divisão era resultante de uma preocupação do Poder Público local em delimitar onde os tuberculosos poderiam tratar-se com os médicos especialistas, em sanatórios e pensões sanatoriais, além de reservar espaços onde indústrias poderiam instalar seus parques industriais sem comprometer "os bons ares" da cidade. ${ }^{14}$

A cidade era considerada, desde o Decreto Estadual n. ${ }^{\circ} 7007$ de 12.03.1935, uma "Estância Climatérica e de repouso", sendo que o Prefeito teria como uma de suas atribuições: "(...) a defesa das condições do melo physico e, em especial, das matas e nascentes de Aguas potáveis (...)". ${ }^{15}$ Esta preocupação era corrente, pois o abastecimento de água no centro urbano da cidade era insuficiente e de pouca qualidade, segundo a opinião de Altino Bondesan: "[uma] piada: a prefeitura vai fornecer um livro de água limpa, para cada litro de água

\footnotetext{
${ }^{13}$ IBGE. Enciclopédia dos Municípios Brasileiros. XXX volume, p. 193. In: <https://biblioteca.ibge.gov.br/biblioteca-catalogo?view=detalhes\&id=227295> Acesso em: 06 jul. 2018.

${ }^{14}$ Cf. PEREIRA, Cristiano José. A cidade, a fábrica e a juventude: a mão-de-obra juvenil na Fábrica de Louças "Santo Eugênio" e o contexto industrial de São José dos Campos-SP (1921-1973). 2009. Dissertação de Mestrado. Faculdade de Filosofia, Letras e Ciências Humanas da Universidade de São Paulo, p. 35-67.

${ }^{15}$ ASSEMBLEIA LEGISLATIVA DO ESTADO DE SÃO PAULO.

<http://www.al.sp.gov.br/repositorio/legislacao/decreto/1935/decreto-7007-12.03.1935.html> Acesso em: 06 jul. 2018.
} 
da torneira. Um para lavar o outro...". ${ }^{16}$ O mesmo autor ainda escreveu: "O que não se pode negar é que esse diploma legal [o Decreto Estadual] teve o efeito de uma Lei Áurea, para a então débil São José dos Campos, que viu surgir o serviço de água, para a qual houve uma verba de 5 mil contos, uma fortuna, para a época $(\ldots)^{17}$

Em 1943, por sugestão do Instituto Brasileiro de Geografia e Estatística, que desejava acabar com topônimos muito parecidos na denominação de cidades, foi proposto que São José dos Campos passasse a denominar-se "Camponésia", sugestão esta que gerou protestos locais e não foi adotada, embora, segundo Altino Bondesan, o termo tenha sido utilizado para "marca de café" e "nome de bezerra". ${ }^{18}$

Em 1947, a constituição de São José dos Campos como "Estância Hidromineral Natural”, juntamente com os municípios de Águas da Prata, Águas de São Pedro, Lindóia, Serra Negra, Ibirá, Amparo, Campos do Jordão, Atibaia, Santa Bárbara do Rio Pardo e Socorro, ${ }^{19}$ levou em consideração uma fonte de água mineral situada em um local denominado "Águas de Canindu". Neste, a própria existência da fonte era periodicamente contestada por membros da política local, ${ }^{20}$ mas jornalistas documentaram a existência da fonte:

AS FONTES EXISTEM? A reportagem resolveu ir em busca da verdade, deslocando-se para a referida fazenda, colhendo material e registrando a existência das fontes de água mineral. Não se trata apenas de uma fonte, mas de seis fontes "lacradas", isto é, cujas águas ou vertentes foram recobertas de paredes de cimento, para que os filetes de água caiam em tanques

\footnotetext{
${ }^{16}$ BONDESAN, Altino. São José em quatro tempos. São Paulo: Bentivegna, 1967, p. 166.

${ }^{17}$ BONDESAN, Altino. "A História e a Estância". In: O VALEPARAIBANO, 27/07/1974, p. 9.

${ }^{18}$ BONDESAN, Altino. São José em quatro tempos. São Paulo: Bentivegna, 1967, p. 95.

19 ASSEMBLEIA LEGISLATIVA DO ESTADO DE SÃO PAULO.

<http://www.al.sp.gov.br/repositorio/legislacao/decreto/1935/decreto-7007-12.03.1935.html> Acesso em: 06 jul. 2019.

20 O VALEPARAIBANO. "A fonte do CANINDU existe mesmo". 20/06/1974, p. 1;5.
} 
subterrâneos. Parte desta água vem abastecer a fábrica de bebidas "Alvorada", de Manoel Joaquim Macedo de Almeida, arrendatário de quatro alqueires de terras, dentro dos quais estão as fontes. A água verte de pedra em filetes mínimos. Uma das fontes ou filetes cai no piso de uma gruta de cimento e pedra e seu gosto é o mesmo das águas "Lindóia". Um cano conduz essa água até um reservatório perto da fábrica de bebidas. As águas das diversas fontes, depois de percorrerem um trecho subterrâneo, vão correr por um vale de mais ou menos quinhentos metros, para alimentar uma lagoa perto da ponte do Pingo D'Água, de onde seguem para o rio Buquira. (... $)^{21}$

Na ocasião, a Prefeitura Municipal de São José entendeu que as águas da fonte de Canindu deveriam ser captadas para o bairro de Vila Cândida, para jorrar “em uma fonte na praça Santa Efigenia com espelho dágua. Custará 125 mil cruzeiros e será entregue em 30 de outubro [de 1974] ${ }^{22}$, para abastecer com água potável o bairro já bastante populoso.

Os artigos 55 e 56 da Lei Estadual n. ${ }^{\circ}$, de 18 de setembro de 1947, registravam:

Artigo 55 - A Constituição de um município em estância hidromineral natural dependerá de lei aprovada por maioria absoluta da Assembléia Legislativa depois de verificado, nos termos da legislação federal, por exames e analises absolutamente concludentes, que o município contem fontes naturais de água dotada de altas qualidades terapêuticas, e em quantidade suficiente para atender aos fins a que se destina.

Artigo 56 - Os municípios constituídos em estâncias hidrominerais naturais compreenderão o território em que estejam localizadas as fontes respectivas, as instalações e obras destinadas ao aproveitamento das águas e a área circunjacente necessária aos objetivos sanitários e turísticos a que se destina a estância.

Em 1950, a criação e instalação do Centro Técnico Aeroespacial (CTA), atualmente, Departamento de Ciência e Tecnologia Aeroespacial (DCTA), trouxe

\footnotetext{
${ }^{21}$ O VALEPARAIBANO. "As fontes do Canindu existem. Elas são seis. Mas não podem ser vistas". 20/06/1974, p. 5. 22 O VALEPARAIBANO. "Prefeito falou sobre 41 melhoramentos levados a efeito em São José dos Campos". 08/08/1974, p. 8.
} 
à cidade o Instituto Técnico Aeroespacial (ITA), responsável pela formação de mão de obra especializada para as indústrias que viessem estabelecer-se em São José dos Campos. A instalação de indústrias na cidade trouxe, segundo o IBGE, um "crescimento demográfico expressivo, que também acelerou o processo de urbanização". ${ }^{23}$ Em 1961, foi criado na cidade a Comissão Nacional de Assuntos Espaciais (CNAE), depois Instituto Nacional de Pesquisas Espaciais (INPE) ${ }^{24}$ Em 1969, a geógrafa Nice Lecocq Müller já apontava São José dos Campos como um município "super-urbanizado". 25

Em 1973 a Prefeitura de São José dos Campos publicou um panfleto denominado "Os Campos de São José ou tudo que São José dos Campos oferece como parque industrial". Neste, a ampla disponibilidade e qualidade de água na cidade era ressaltada:

O que a indústria consome de água dá e sobra[:] Para chegar onde São José dos Campos está, muita água já correu. Ainda bem que o município conta com uma base hidrográfica inesgotável. O sistema hidráulico da região é riquíssimo, tanto na superfície como nos lençóis subterrâneos. Possui os rios Paraíba, Buquira, Peixe, Turvo e Jaguari. Foi constatada uma precipitação pluvial anual média de $1.400 \mathrm{~mm}$. Os poços artesianos cadastrados mostraram que numa profundidade média de $140 \mathrm{~m}$. obtêm-se uma vazão de $100 \mathrm{~m} / \mathrm{h}$. A região é a melhor possível para efeito de exploração de água subterrânea, tanto pela favorabilidade da estrutura geológica como pela reposição das águas na sedimentação dos aquíferos. Sem risco de erro, pode-se dizer, com certo orgulho, que num raio de 300 quilômetros de São Paulo não existe nenhum sub-solo com idêntica riqueza de água química e bacteriologicamente pura. ${ }^{26}$

\footnotetext{
${ }^{23}$ IBGE. Brasil em síntese. São Paulo. São José dos Campos. In: <https://cidades.ibge.gov.br/brasil/sp/sao-jose-doscampos/historico>. Acesso em: 06 jul. 2019.

${ }^{24}<$ http://www.inpe.br/institucional/sobre_inpe/historia.php>. Acesso em: 07 jul. 2018.

${ }^{25}$ MÜLLER, Nice Lecocq. O fato urbano na bacia do Paraíba - São Paulo. Rio de Janeiro: Fundação IBGE, 1969, p. 10.

${ }^{26}$ PREFEITURA MUNICIPAL DE SÃO JOSÉ DOS CAMPOS. Panfleto "Os Campos de São José ou tudo que São José dos Campos oferece como parque industrial", 1973, s.p.
} 
São José dos Campos, a partir de 1977, deixou de lado a identidade que a população assumia na década de 50: a de serem conhecidos popularmente como "formigueiros", 27 como documentado na "Enciclopédia dos Municípios Brasileiros" do IBGE, em alusão às formigas saúvas que infestavam a cidade. Era corrente, para os caboclos locais, utilizar a expressão "É pau com formiga!", para "qualificar as coisas nocivas". ${ }^{28}$

Neste contexto de abandono da identidade de uma cidade de tratamento de tuberculosos, e assumindo o rótulo de uma cidade industrial, por conta do progresso resultante de um processo de industrialização e urbanização acelerados, ${ }^{29}$ que incrementava o setor terciário da economia, através de incentivos à instalação de grandes lojas de departamentos, tais como as Lojas Americanas ${ }^{30}$ e o Peg-Pag, ${ }^{31}$ além da transformação da rua Sete de Setembro em "Calçadão"32 e inauguração de um Shopping de médio porte no centro da cidade, ${ }^{33}$ São José dos Campos deixou de ser considerada uma estância hidromineral em 05/10/1977, com a Lei Estadual n. ${ }^{0} 1402,{ }^{34}$ após proposição de Robson Marinho, então deputado estadual. ${ }^{35}$

A geógrafa Nice Lecocq Müller analisar elementos desta mudança de identidade na cidade de São José dos Campos na década de 60 do século passado:

\footnotetext{
${ }^{27}$ IBGE. Enciclopédia dos Municípios Brasileiros. XXX volume, p. 196. In: <https://biblioteca.ibge.gov.br/biblioteca-catalogo?view=detalhes\&id=227295> Acesso em: 06 jul. 2018.

${ }^{28}$ BONDESAN, Altino. São José em quatro tempos. São Paulo: Bentivegna, 1967, p. 132.

${ }^{29}$ Cf. PEREIRA, Cristiano José. A cidade, a fábrica e a juventude: a mão-de-obra juvenil na Fábrica de Louças "Santo Eugênio" e o contexto industrial de São José dos Campos-SP (1921-1973). 2009. Dissertação de Mestrado. Faculdade de Filosofia, Letras e Ciências Humanas da Universidade de São Paulo, p. 76.

${ }^{30}$ Atualmente funciona no ponto comercial das Lojas Americanas a Comercial Esperança, um atacadista do ramo alimentício.

${ }^{31}$ Atualmente funciona no ponto comercial do Peg-Pag o Hipermercado Extra.

32 O VALEPARAIBANO. "Rua sete será exclusivamente para pedestres", 07/06/1972, p. 1.

33 O VALEPARAIBANO. "Lançamento do Shopping Centro", 06/06/1974, p. 1;5. O Shopping ainda se encontra em funcionamento no mesmo local, sem grandes alterações arquitetônicas.

${ }^{34}$ ASSEMBLEIA LEGISLATIVA DO ESTADO DE SÃ̃O PAULO.

<https://www.al.sp.gov.br/repositorio/legislacao/lei/1977/lei-1402-05.10.1977.html>. Acesso em: 06 jul. 2019.

${ }^{35}$ Robson Riedel Marinho foi prefeito de São José dos Campos entre 1983 e 1986.
} 
Se a consciência de solidariedade comunitária pode estar presente em São José dos Campos, acirrada pelo orgulho de ser "a cidade que mais cresce no Vale do Paraíba" e pela rivalidade com Taubaté, o sentido regional parece muito esmaecido: a proximidade de São Paulo, o fato de estarem as maiores organizações industriais diretamente ligadas à Capital, as relações existentes entre certos serviços e área metropolitana (como as escolas superiores, por exemplo), a heterogeneidade de sua população, com pequenos contingentes locais e da região, fazem com que São José dos Campos esteja relativamente desvinculada do Vale do Paraíba. Aliás, essa realidade se projeta em sua paisagem de cidade completamente modernizada, pouco ligada aos padrões regionais, em que o afluxo de levas vindas de fora chega a traduzir-se em bairros, como o "mineiro" do Alto da Ponte ou o "nordestino" de Linha Velha... [a primeira favela da cidade] ${ }^{36}$ (Müller, 1969, p. 289)

A década de 80 foi uma época de crise econômica no Brasil. Várias indústrias de São José dos Campos fecharam as portas ou começaram a atrasar salários a seus funcionários (Amplimatic, Cerâmica Weiss, Engesa). A Prefeitura da cidade não escapou a esta penúria, chegando a ter $131 \%$ da renda do município comprometida para pagar o funcionalismo público. ${ }^{37}$ Entretanto, empreendimentos comerciais, mesmo com a crise econômica, eram inaugurados, tal como o CenterVale Shopping, no mesmo local do primeiro parque industrial da Ericsson ${ }^{38}$ na cidade:

Inaugurado em 28 de maio de 1987, o CenterVale Shopping mudou a realidade do comércio no Vale do Paraíba, o primeiro grande centro comercial da região alta tradição e vanguarda inovando cada vez mais o seu conceito de moda, entretenimento e serviços, numa identificação com a cidade e criando vínculo com os frequentadores de outras regiões. ${ }^{39}$

\footnotetext{
${ }^{36}$ MÜLLER, Nice Lecocq. O fato urbano na bacia do Paraíba - São Paulo. Rio de Janeiro: Fundação IBGE, 1969, p. 289.

${ }^{37}$ O VALEPAIBANO. "Bevilacqua recebe o cargo e vários problemas". 01/01/1989, p. 3.

${ }^{38}$ A Ericsson, empresa sueca de telefonia, é instalada em São José dos Campos no ano de 1955. Sua expansão levou à construção de um novo parque industrial no distrito joseense de Eugênio de Mello, em 1974. Cf. SANTOS, Ademir Pereira dos. Arquitetura Industrial. São José dos Campos: A. P. Santos, 2006, p. 151.

$39<\mathrm{https}$ ://www.centervale.com.br/card/sobre-o-shopping>. Acesso em: 08 jul. 2018.
} 
Na década seguinte, com uma recuperação econômica proporcionada principalmente após o Plano Real (1994), São José dos Campos foi a sede de um incremento na economia local no setor terciário. O IBGE registrou este incremento:

Nos anos 90 e início do século 21, São José dos Campos passou por um importante incremento no setor terciário. A cidade é um centro regional de compras e serviços, com atendimento a aproximadamente 2 milhões de habitantes do Vale do Paraíba e sul de Minas Gerais. ${ }^{40}$

Nice Lecocq Müller, em 1969, indicava como "centros urbanos com função específica nos dois setores [secundário e terciário] (com predominância do industrial)" a cidade de São José dos Campos. ${ }^{41}$ No final do século 20 e começo do século 21 a cidade recebeu hipermercados (Carrefour, Wal Mart, Tenda Atacado), shopping centers (“CenterVale”, inaugurado em 1987), "Vale Desconto" (novembro de 1994), renomeado como "Vale Sul" em agosto de 2002,42 e Shopping Colinas, de $1997 .{ }^{43}$ Redes de comércio varejista criaram lojas cada vez maiores no "Calçadão" da cidade, situado na rua Sete de Setembro, mesmo com uma apreensão dos comerciantes na ocasião da instalação do CenterVale na cidade:

[Artur Anurulian, comerciante:] Ele acompanhou toda a polêmica sobre transformar a Rua Sete de Setembro em Calçadão, já que

\footnotetext{
${ }^{40}$ IBGE. Brasil em síntese. São Paulo. São José dos Campos. In: <https://cidades.ibge.gov.br/brasil/sp/sao-jose-doscampos/historico>. Acesso em: 06 jul. 2019.

${ }^{41}$ MÜLLER, Nice Lecocq. O fato urbano na bacia do Paraíba - São Paulo. Rio de Janeiro: Fundação IBGE, 1969, p. 213.

$42<$ http://www.valesulshopping.com.br/historico.php>. Acesso em: 07 jul. 2018.

${ }^{43}<$ https://www.colinasshopping.com.br/\#oshopping>. Acesso em: 07 jul. 2018.
} 
muitos comerciantes temiam que o desvio do trânsito pudesse acabar desviando também o consumidor (...) Mais recentemente, ele participou da discussão sobre a ameaça que a vinda do CenterVale Shopping representava para o comércio do centro da cidade (...) O shopping já não assusta e nem representa uma ameaça aos lucros dos comerciantes: "Os consumidores foram para o CenterVale nos primeiros meses porque era novidade, mas depois voltaram. Lá as pessoas passeiam mas é aqui que elas compram." $(\ldots)^{44}$

Por outro lado, indústrias como a Alpargatas, Engesa, Rhodia, Kone, Philips, Tectran, Solectron e a Kanebo encerraram as suas atividades no município no período, ${ }^{45}$ provocando, portanto, o corte de centenas de postos de trabalho. Parte desta força de trabalho reposicionou-se no setor terciário, fazendo São José dos Campos ser referência comercial no Vale do Paraíba paulista.

Neste contexto de incremento do setor terciário em São José dos Campos, houve valorização de terras e a urbanização de bairros cada vez mais afastados. Bairros da Zona Norte de São José dos Campos, tais como o Mirante do Buquirinha, que chegou a ocupar com casas uma zona de várzea do Rio Buquira, e o Taquari, que ocupa uma região muito próxima ao Rio Buquira e se espraia pelos morros da região, são o resultado da ocupação humana em regiões que, em tese, deveriam ser preservadas por ações do Poder Público.

Os geógrafos José Oswaldo Soares de Oliveira e Cilene Gomes comentam sobre o crescimento da cidade de São José dos Campos desde a segunda metade do século passado:

\footnotetext{
${ }^{44}$ O VALEPARAIBANO. "CALÇADÃO: O armarinho da cidade". 29/01/1989, p. 15.

${ }^{45}$ A Alpargatas teve as suas instalações fabris transformadas no Shopping "Vale Desconto" (hoje Vale Sul Shopping); as instalações da Engesa foram adquiridas pela EMBRAER; os galpões da Rhodia e da Philips fazem parte de condomínios industriais; a Kone foi transformada na sede da Universidade Anhanguera, instituição de ensino superior particular; a Tectran hoje sedia a Sodimac, empresa que vende artigos de "Casa e Construção"; a Solectron hoje é o prédio sede do "Parque Tecnológico" mantido pelo município; a Kanebo sedia hoje o Shopping "Jardim Oriente", cuja principal loja é a rede de supermercados Shibata.
} 
Com as obras públicas dos prefeitos sanitaristas, os favores especiais para a atração de indústrias, a delimitação de perímetros para as diferentes zonas de uso e ocupação, os planos diretores e demais legislações urbanísticas, o crescimento da cidade passa a ser orientado/controlado, mas dando-se, de forma linear ou pontual, segundo os mesmos mecanismos de produção do espaço urbano: retenção especulativa e posterior ocupação dos vazios urbanos (com a extensão onerosa de infraestruturas) e, ainda, ampliação das bordas urbanizadas, mediante 0 loteamento de áreas rurais, a oferta de novas áreas urbanizáveis e a formação de novas centralidades ao redor das grandes implantações para a indústria, o grande comércio ou serviços (hospedagem, educação etc.) ${ }^{46}$

Em nossa opinião, os recursos hídricos devem ser cada vez mais

estudados para a melhor compreensão do espaço compreendido pela cidade de

São José dos Campos. Um relato sobre o Rio Buquira foi realizado em 1988:

(...) Seguindo o velho ditado que diz que "quem não tem cão caça com gato", a população da periferia também busca suas maneiras de refrescar o calor. Vale tomar banho de mangueira quando não falta água, e até tomar banho de rio e em lagoas. Na zona norte da cidade, na região da Vila Cândida, as crianças não se intimidam com a poluição do Rio Buquira, e o perigo à saúde que a água suja pode causar. O que vale mesmo é espantar o calor. Num longo trecho do rio, entre o bairro Buquirinha até sua foz do Rio Paraíba, no Alto da Ponte, o Buquira torna-se a piscina da população. "A gente chega aqui na hora do almoço e só sai no fim da tarde", diz Adilson Cabral, 15 anos, enquanto se prepara para dar um mergulho nas águas barrentas do rio. "De vez em quando alguém se machuca", fala Ivan dos Santos, 15 anos, que frequenta o local desde criança. ${ }^{47}$

Altino Bondesan, em 1967, delimitou a presença do Rio Paraíba na cidade com uma curta sentença: “(...) O Paraíba divide dois mundos. À direita,

\footnotetext{
${ }^{46}$ OLIVEIRA, José Oswaldo Soares de; GOMES, Cilene. "Introdução à urbanização contemporânea: espaços e paisagens na região do Vale do Paraíba (SP)". In: COSTA, Sandra Maria Fonseca de; MELLO, Leandro Freire de. Crescimento urbano e industrialização. São José dos Campos: Intergraf, 2010, p. 62.

${ }^{47}$ O VALEPARAIBANO. "38 graus: quem aguenta?". 20/01/1988, p. 3.
} 
cidades, progresso, civilização. À esquerda - mato!" ${ }^{48}$ Nesta região de "mato" suprimido em ritmos diversos na cidade de São José dos Campos na série temporal 1985-2015, houve uma expansão urbana considerável, a ponto de reivindicações comuns à população de bairros mais urbanizados serem realizadas na Zona Norte de São José dos Campos: esgoto, ${ }^{49}$ asfalto nas ruas, ${ }^{50}$ proteção contra alagamentos, inundações e deslizamentos. ${ }^{51}$

\subsection{Legislação Ambiental na Bacia do Rio Buquira}

Concomitantemente ao Planejamento Ambiental, o Planejamento Urbano se torna um importante instrumento na produção e organização do espaço, através de políticas públicas desenvolvidas pelo Estado.

Verificamos em lei, principalmente nos Planos Diretores e Leis de Zoneamento Urbano, as áreas compreendidas na Bacia Hidrográfica do Rio Buquira.

A Lei Orgânica de São José dos Campos, promulgada em 05 de abril de 1990 - tendo sua última emenda em 08 de dezembro de 2008 (emenda n076/11) - determina o Rio Buquira como uma área ambientalmente protegida, sendo que o município fica submetido "a implantar e manter áreas verdes de preservação permanente, de acordo com os parâmetros fixados pela Organização Mundial de Saúde" (Art. 246).

\footnotetext{
48 BONDESAN, Altino. São José em quatro tempos. São Paulo: Bentivegna, 1967, p. 82.

${ }^{49}$ O VALEPARAIBANO. "Deputados pedem esgoto à Sabesp". 07/03/1985, p. 4.

50 O VALEPARAIBANO. "Morador pede asfalto na zona norte". 12/01/2005, p. 6.

51 O VALEPARAIBANO. "Onde mora o perigo". 06/01/1995, p. 3.
} 
Na Lei $12.651 / 12$, art. $3^{\circ}$ temos a definição de Área de Preservação Permanente (APP) como "área protegida, coberta ou não por vegetação nativa, com a função ambiental de preservar os recursos hídricos, a paisagem, a estabilidade geológica e a biodiversidade, facilitar o fluxo gênico de fauna e flora, proteger o solo e assegurar o bem-estar das populações humanas".

Para a extensão das Áreas de Preservação Permanente em zonas rurais ou urbanas, temos na mesma lei supracitada (complementada pela Lei 12.727/12), art. $4^{\circ}$ as seguintes considerações:

I - as faixas marginais de qualquer curso d'água natural perene e intermitente, excluídos os efêmeros, desde a borda da calha do Leito Regular, em largura mínima de:

a) 30 (trinta) metros, para os cursos d'água de menos de 10 (dez) metros de largura;

(...)

IV - as áreas no entorno das nascentes e dos olhos d'água perenes, qualquer que seja sua situação topográfica, no raio mínimo de 50 (cinquenta) metros.

Parcialmente, a bacia do Rio Buquira faz parte de APA federal, instituída pelo Decreto $87.561 / 82$, que apresenta medidas de recuperação e proteção ambiental, entretanto o Decreto possui apenas caráter genérico, não regulamentado pelos órgãos federais. (Caderno Diagnóstico da Lei de Zoneamento, 2010)

As Leis de Zoneamento Urbano e os Planos Diretores determinam o Macrozoneamento urbano, direcionado ao crescimento da cidade, sendo que o Macrozoneamento do Plano Diretor de Desenvolvimento Integrado (PPDI-1995) segue as orientações definidas pela Carta das Unidades Territoriais de Características físicas e antrópicas homogêneas. 
Neste macrozoneamento, o Rio Buquira encontra-se na Unidade 5, que possui "severas restrições ao desenvolvimento urbano devido às características geomorfológicas. Permite atividades de lazer e turismo, ocupação de baixa densidade, como chácaras. Permite, também, o uso agrícola." (REANI, 2012, p. 108)

Esta foi dividida em Zona Rural e Zona de Expansão Urbana II.

O PPDI discute, também, outro problema grave, que é a poluição e uso das águas, quanto aos efluentes industriais e esgoto "in natura", e o problema se estende quanto se trata das demais cidades do Vale do Paraíba:

O problema da degradação dos recursos hídricos da Bacia do Rio Paraíba do Sul, fica mais complexo a medida em que se dá - lançamento de água a montante e a captação de água a jusante pelos municípios situados às margens do Rio Paraíba e seus afluentes. Este fato agrava-se devido a pequenas distâncias entre os pontos de lançamento e captação das redes urbanas, dificultando a auto-depuração da água e provocando como consequência o acréscimo nos custos de tratamento da água a ser distribuída a população. (Caderno PPDI, 1995, p.112)

A Lei de Zoneamento Urbano de 2010 (Lei complementar nº428 de 2010), promove modificações em relação no macrozoneamento. A bacia hidrográfica do Rio Buquira passa a fazer parte das seguintes zonas, de acordo com o Capítulo III "do Zoneamento do Território:

- ZEPH - Zona Especial de Preservação do Patrímonio Histórico, Paisagístico e Cultural;

- $\quad$ NPRF - Núcleo passível de regularização fundiária (loteamentos clandestinos não delimitados por lei); 
- $\quad$ ZAl - Zona de assentamento informal são áreas de assentamentos urbanos, não sendo de interesse social, localizados em áreas privadas, compreendendo os parcelamentos irregulares ou clandestinos;

- ZEIS - Zona Especial de Interesse Social, área destinada a projetos residenciais voltados à população de baixa renda;

- $\quad$ ZR - Zonas residenciais, que se diferenciam pelo tamanho do lote e uso vertical ou horizontal;

- $\quad$ ZM - Zona mista.

Para a área, as maiores modificações estão centradas no que tange a redução do perímetro Norte de São José dos Campos (região sul da Bacia) e a representativa classe de loteamentos clandestinos.

Reani (2012) tece considerações sobre o problema dos loteamentos clandestinos:

\begin{abstract}
A área rural do município possui terreno acidentado e pouco fértil, sendo utilizado para a pecuária leiteira e o cultivo de eucalipto. O enfraquecimento econômico do setor primário propiciou uma ociosidade das terras rurais. Este fato, aliado ao grande crescimento demográfico de São José dos Campos, à falta de uma política habitacional e ao alto custo das terras urbanas, acarretaram grande especulação imobiliária das terras rurais, contribuindo para o parcelamento irregular do solo e grande número de loteamentos clandestinos (REANI, 2012, p. 114).
\end{abstract}

Ainda à respeito do Zoneamento Urbano de 2010, a lei complementar 428/2010, sobre o Parcelamento, uso e cobertura da terra, prevê que, quando a gleba objeto do loteamento estiver situada na Bacia do Rio Buquira e inserida 
nas áreas de controle de impermeabilização, será exigido um adicional de $20 \%$ de área verde.

Por fim, o Plano Municipal de Saneamento Básico (PMSJC, 2008) informa que o sistema é dividido em seis bacias principais de esgotamento, uma delas a bacia do Rio Buquira. Conforme o Plano, a bacia possuía $85 \%$ de coleta e $65 \%$ de tratamento. 
CAPÍTULO II

\section{Procedimentos \\ metodológicos}


Para alcançar os objetivos propostos nesta pesquisa, fizemos o levantamento e revisão bibliográfica de conceitos e temas norteadores sobre análise da paisagem, bacias hidrográficas, técnicas de geoprocessamento utilizando a ferramenta SIG, processos de produção do espaço urbano e história da área da bacia hidrográfica.

Este trabalho foi elaborado a partir das concepções metodológicas de Leal (1995), Rodriguez (2010), Tundisi et alii (2006) e Guerra e Marçal (2014) sobre o estudo do meio físico e as intervenções do ser humano no solo, notadamente próximo a rios, além da necessária avaliação ambiental.

São orientações básicas para estudar os efeitos da ação antrópica no meio físico (RODRIGUES, 1999):

- Interpretar as ações humanas como ações geomorfológicas na superfície terrestre;

- Investigar nas ações humanas padrões significativos para a morfodinâmica;

- Investigar e realizar a cartografia geomorfológica de detalhe;

- Explorar a abordagem sistêmica;

- Analisar de forma integrada os sistemas geomorfológicos.

José Galizia Tundisi et alii (2006), afirmam, em relação ao desmatamento, que prejudica os solos ribeirinhos:

Perda da zona tampão entre sistemas terrestres e aquáticos, aumento do material particulado em suspensão na água, perda de florestas ripárias e habitats [it. dos autores] para as aves aquáticas, alterações na composição do sedimento dos sistemas aquáticos. (TUNDISI et alii, 2006, p. 219) 
Segundo Moroz-Caccia Gouveia (2010), o mapeamento geomorfológico é um instrumento de pesquisa que compreende, antes de tudo, ao processo de investigação:

Diferentemente de outros mapas temáticos que representam os resultados finais de pesquisas, o mapeamento geomorfológico é que conduz à análise, à medida que possibilita a espacialização e integração de descrições acerca das formas, materiais, idade e gênese do relevo (MOROZ-CACCIA GOUVEIA, 2010, p. 29).

Assim, analisar a concepção geomorfológica de uma área envolve processos e sistemas complexos, que podem tanto agir isoladamente quanto interagir, resultando em mudanças ambientais e, sobretudo, num remodelamento da paisagem, por influência da intervenção do homem e/ou natural (GUERRA e MARÇAL, 2014).

Para a caracterização da área de estudo, foram elaborados mapeamentos, através do Sistema de Informações Geográficas (SIG), utilizado para coletar, armazenar, recuperar, transformar e visualizar dados e informações necessárias ao mapeamento.

$\mathrm{Na}$ etapa do inventário, foram elaboradas cartas temáticas, tais como: hipsometria, declividade, geologia, pedologia, geomorfologia, clima, uso e cobertura da terra, dentre outros. Para constatar as transformações no uso e cobertura da terra utilizaremos o aplicativo Land Change Modeler (LCM), desenvolvido pela Clark Labs com o apoio do Andes Center for Biodiversity Conservation of Conservation International, "capaz de integrar recursos dinâmicos para a modelagem de cenários direcionados à variação do ambiente e da biodiversidade [...] que abrange funções associadas à análise de mudanças, 
previsão e modelagem de variáveis relativas às transições do ambiente e habitat." (TERRSET, 2015). A partir deste módulo foi possível a análise das mudanças a partir dos mapas de uso e cobertura da terra e geração dos gráficos de ganho e perda para cada classe.

\subsection{Documentação cartográfica}

- Base de dados vetoriais em formato DGN - convertida posteriormente em shape (shp) - das cartas topográficas na escala de 1:50000 do IBGE - SF-23Y-B-V-3 (Folha Monteiro Lobato) e SF-23-Y-D-II-1 (Folha São José dos Campos);

- Imagem de satélite Landsat, dos anos de 1985, 1995, 2005 e 2015, na composição 543 em RGB para Landsat 5 e 432 em RGB para Landsat 8;

\subsection{As ferramentas cartográficas}

- Banco de dados alimentado no software ArcGis - Arclnfo, versão 101/ESRI, para a produção das cartas temáticas;

- Idrisi versão Taiga, para a modelagem das transformações na área da bacia;

- AutoCad 2006, para o tratamento dos vetores adquiridos no IBGE, edição das isolinhas e layers;

- Google Earth Pro, versão 7.1.2. 


\subsection{Mapeamento temático}

Para a confecção das cartas temáticas, adotamos a projeção SIRGAS 2000, no software ArcGis 10.1. Foi necessária a conversão de alguns shapefiles preexistentes para a área da bacia, originalmente em WGS 84.

Inicialmente, convertemos a base cartográfica para shapefile e vetorizamos manualmente a delimitação da bacia hidrográfica para geração do mapa base. Posteriormente, editamos os atributos e atribuímos valor $z$ às curvas de nível para geração da grade TIN.

A partir da ferramenta Create TIN, utilizando as linhas de drenagem como linha de quebra, elaboramos a carta hipsométrica, divididas em 9 classes (560684, 684-808, 808-933, 933-1057, 1057-1182, 1182-1306, 1306-1431,14311555 e 1555-1680 metros).

Após a grade TIN ter sido criada, utilizamos a ferramenta Slope para a geração da carta clinográfica, de acordo com as classes de declividade de Herz e Debiasi (1989): 0-5\%, 5-12\%, 12-30\%, 30-47\%, e >47.

As cartas geológicas e pedológicas, de fontes distintas, foram georrefenciadas, editadas e observadas à campo e na imagem de satélite para algumas adaptações. Utilizamos a ferramenta edição topológica.

Para a confecção da carta de compartimentos geomorfológicos, medimos a dimensão interfluvial e o desnível altimétrico entre as áreas de topo e fundo de vale, através da ferramenta de operações métricas do Arcgis e segundo ROSS et al (1997). 
Elaboramos a carta de uso e cobertura da terra, dos anos de 1985, 1995, 2005 e 2015, onde optamos pelas utilização das imagens do satélite Landsat, por conter todo este período histórico estudado e devido ao seu tempo de vida útil.

A série LANDSAT teve início na segunda metade da década de 60 , e até os dias de atuais foram lançados 8 satélites (INPE, 2019). Utilizamos as imagens multiespectrais do satélite LANDSAT-5 (que obteve imagens entre 1984 e 2011), do sensor Thematic Mapper (TM), com 30m de resolução espacial e a imagem multiespectral do satélite LANDSAT-8 (desde 2013), do sensor OLI (Operational Terra Imager) e TIRS (Thermal Infrared Sensor), com 15 a 30 metros de resolução.

$\mathrm{Na}$ figura 6, podemos observar os anos de atividade de cada satélite da série LANDSAT, a partir de 1972: 
Figura 6: Atividade do satélite LANDSAT (1972-até os dias atuais)

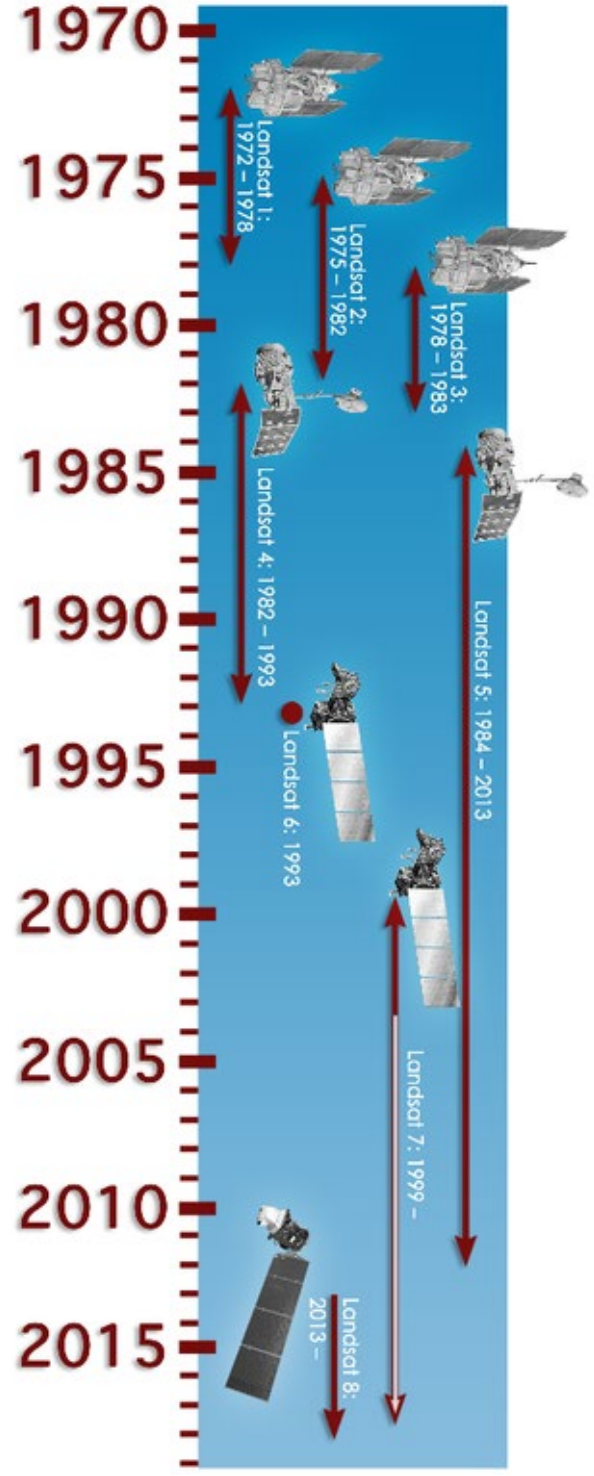

Fonte: Geração de imagens.

http://www.dgi.inpe.br/documentacao/satelites/landsat

Para a confecção desta carta, realizamos um prévio trabalho de campo para a constatação in loco. Utilizamos o software ArcGis para a coleta de amostras e classificação da imagem, escolhendo o método de classificação supervisionada pelo classificador Maximum Likelihood. Este classificador de verossimilhança agrupa os pixels coletados e estima os valores mais próximos para os conjuntos de classes. Nos baseamos em sete classes: Área construída, 
Pastagem, Solo exposto, Reflorestamento, Floresta primária, Vegetação secundária e Água.

Após este procedimento, comparamos ainda, o resultado da classificação ao realizado pelo software Spring e executamos a pós classificação, onde estabelecemos o limiar de aceitação e a probabilidade do pixel de pertencer à duas classes ou mais classes.

\subsection{0 módulo LCM}

Após serem confeccionadas as cartas de uso da terra, exportamos os polígonos de cada ano em shapefile, criamos um projeto no software Idrisi versão Taiga e importamos os vetores através do menu File/lmport.

Posteriormente, a imagem importada foi salva como um vetor e rasterizada através do menu Data Entry/Initial. Definimos os parâmetros de coordenadas e finalizamos a transformação da imagem em raster através do menu Reformat/Raster Vector.

Ao efetuar este processo para cada imagem executamos a ferramenta Land Change Module e inserimos os anos a serem comparados. Assim, é possível elaborar os mapas de ganhos e perdas de cada categoria de uso da terra, bem como realizar demais análises.

Observamos a confecção das cartas no software Idrisi 17.0 - The Selva Edition (figura 7) 
Figura 7: Execução do banco de dados no software Idrisi

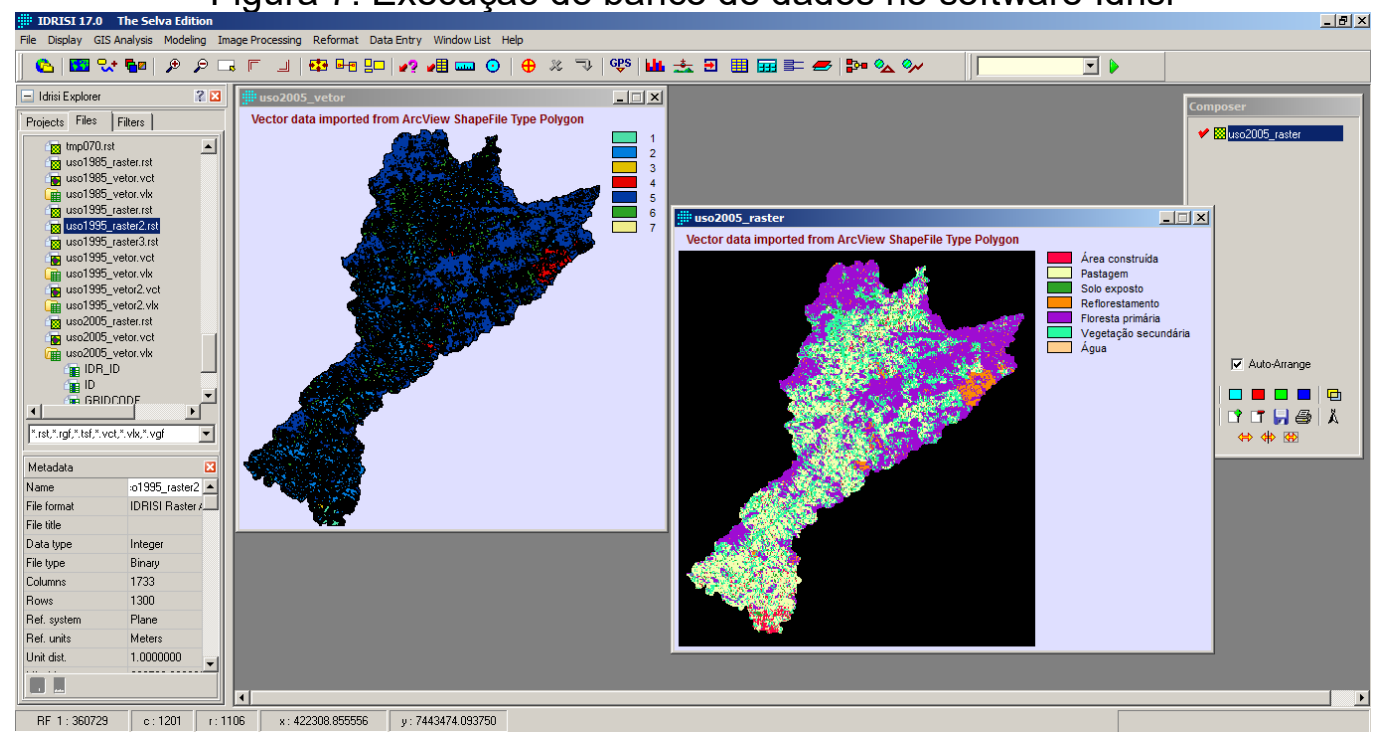

Fonte: Autora

\subsection{Trabalhos de campo}

Os trabalhos de campo realizados na bacia foram importantes para o conhecimento inicial da área, para a averiguação de pontos de controle as imagens de satélite, para prévias análises hidrológicas, e para o levantamento de dados atuais e históricos na região de São José dos Campos e Monteiro Lobato (figura 8).

Inicialmente percorremos a Rodovia SP-50 a partir da Rodovia SP-46 (Oswaldo Barbosa Guisard), até a cidade de São José dos Campos, onde se encontra a foz do Rio Buquira, que deságua no Rio Paraíba do Sul para identificação da área de pesquisa;

Posteriormente, foi realizada visita ao Departamento de Águas e Energia Eletrica (Bacia do Paraiba e Litoral Norte) na cidade de Taubaté para obtenção do Plano de Bacia Hidrográfica do Rio Paraíba do Sul (UGRHI-02), bem como arquivos vetoriais inseridos no Plano; visita à Secretaria do Meio Ambiente em 
São José dos Campos, para obtenção de imagens de satélite recentes da bacia e base de logradouros (estivemos em diálogo com a Coordenadoria de Planejamento Ambiental/SMA de São Paulo para este fim) e visita à Prefeitura de Monteiro Lobato, com o intuito de obter informações históricas sobre o uso e cobertura do município e relatório sobre ocorrência de problemas ambientais na região;

Após isto, fizemos um amplo trabalho de campo que focou-se na averiguação do uso e cobertura da terra em alguns pontos na bacia, para a devida classificação das áreas utilizando o Sensoriamento remoto. Demos atenção especial à uma área da bacia, localizada no bairro Mirante do Buquirinha, onde constantemente há o registro de alagamentos e quedas de barreiras.

Fomos, ainda, à área na data de 16 de janeiro de 2016 devido ao transbordamento do Rio Buquira e deslizamentos de terra na SP-50 (figura 9), na noite anterior. De acordo com a Defesa Civil de São José dos Campos, o pluviômetro do município de Monteiro Lobato, por onde passa o Rio Buquira, registrou $63,4 \mathrm{~mm}$ de chuva e no acumulado dos últimos três dias, de $82,4 \mathrm{~mm}$, o que configura estado de atenção.

Para complementar as análises hidrológicas, realizamos quatro trabalhos de campo específicos para a visitação dos cursos d'água, onde buscamos averiguar a quantidade e qualidade da água, parâmetros de drenagem, focos de erosão e assoreamento e condição das matas ciliares. 
Figura 8: Pontos visitados nos trabalhos de campo na área de pesquisa

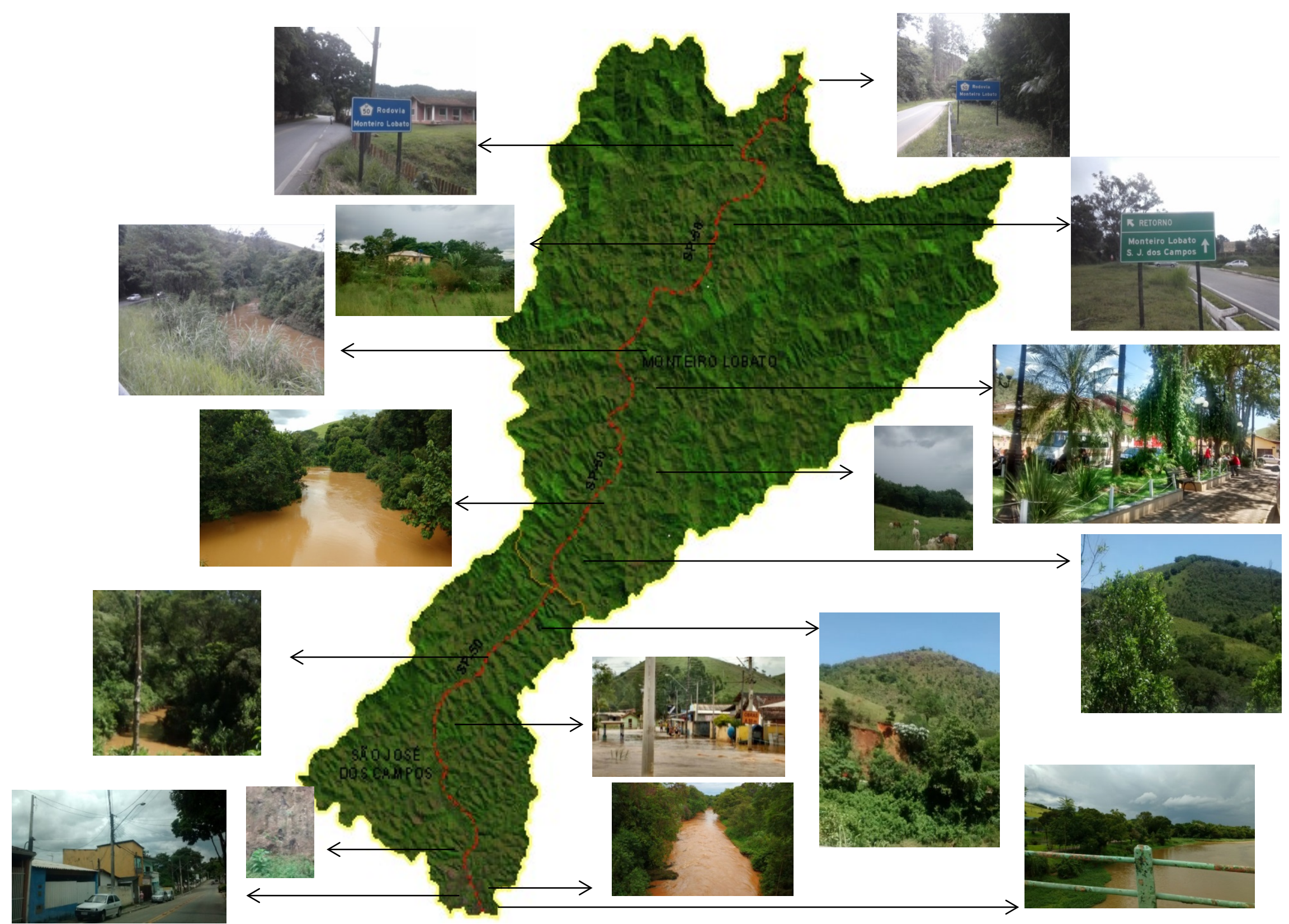

Fonte: Trabalho de campo (fotografia dos anos de 2015 a 2019) 


\section{Bairros visitados em Monteiro Lobato:}

Para um panorama geral, percorremos a área através das estradas asfaltadas e de terra, e ao longo do trajeto foram feitas anotações, para posteriormente, relacionarmos estas áreas às cartas ambientais da bacia.

No geral, a porção Sul possui topografia mais suave, vertentes íngrimes próximas à drenagem e pastos "sujos", mata capoeira e vegetação em transição (estas duas últimas categorias, englobamos na classe "vegetação secundária" na carta de uso e cobertura da terra). Observamos alguns pontos de erosão laminar moderada.

Na porção central do município, em áreas de morros e maior declividade - comparando-se à porção sul - foram identificadas áreas de reflorestamentos, predominância de pastagem e áreas sujeitas à movimentos de massa

Ao Norte e nordeste da bacia, de relevo escarpado, altitudes maiores de 1200 m e declividade acentuada não foi possível percorrer à pé devido à presença da mata fechada (Floresta ombrófila e araucárias). Devido ao abandono dos pastos já esgotados pelos pecuaristas, essa área já foi abundantemente explorada para formação de novos pastos, ainda que hajam restrições legais que impeçam este feito.

Os bairros de maiores extensões visitados foram o Bairro do Souza, Jardim São Benedito, Bairro Pedra Branca e Centro de Monteiro Lobato, onde transcrevemos as seguintes anotações:

- O Bairro do Souza, localizado às margens da Estrada Municipal Benedito Monteiro do Prado, abriga moradores da região e residentes de outras 
regiões, em chácaras de lazer, com de ocupação de residências de médio e baixo poder aquisitivo (em maior quantidade|). O núcleo urbano apresenta pouca estrutura, com comércio pouco desenvolvido, porém possui uma escola de educação infantil e uma igreja.

- O Bairro São Benedito, situado às margens da Rodovia Monteiro Lobato (SP 050), é um bairro adensado de população de baixo poder aquisitivo, alojando-se em encosta de declividade acentuada e possuindo arruamento precário. Comércios e serviços podem ser classificados como quase que inexistentes. Duas das maiores construções na área são uma igreja e uma escola infantil - quase um modelo padrão nos bairros de Monteiro Lobato.

- O Bairro Pedra Branca, que já foi loteamento irregular, apresenta, em grande parte, áreas de pastagem (pecuária leiteira e de corte), pequena área de mata preservada, reflorestamento e atividades como piscicultura. Possui um "centrinho", que abriga a Igreja de Santo Antônio e um centro comunitário. Neste bairro encontra-se o "Sítio do Pica-Pau Amarelo", que foi propriedade de Monteiro Lobato e antigo nome de "Fazenda Buquira".

$\mathrm{Na}$ porção central do município, encontramos a cidade de Monteiro Lobato, com cerca de 4000 habitantes. O "centrinho" se limita a alguns quarteirões em volta da Igreja Matriz. São encontradas escolas infantis, de nível fundamental e médio, e boa estrutura de comércios e serviços como diversos restaurantes e pousadas. A prefeitura localiza-se próxima à igreja Matriz. Atualmente, a prefeita é Daniela de Cássia Santos Brito (PSB). Os núcleos urbanos são de baixo, médio e alto padrão. No entorno da cidade, encontramos área de pecuária leiteira, vegetação secundária em estado de média 
conservação e pequenas áreas de reflorestamento. Foi localizada uma área de risco, com grande potencial de deslizamentos.

Encontramos, também, bairros de menor extensão e sem aglomerados urbanos concentrados, que são: Vargem Alegre, Serrinha, Matinada, e Ponte Nova:.Este último, situado às margens da Estrada Municipal dos Teixeiras, apresenta alguns empreendimentos turísticos, chácaras de lazer e abriga diversas cachoeiras.

Alguns problemas ambientais foram identificados, como pontos de erosão nos bairros Vila Esperança, Jardim Morada do Sol (de grande extensão) e erosão na estrada do Livro; solapamento nas margens do Ribeirão do Souza e assoreamento no córrego Paciência, dentro outros pequenos pontos isolados.

\section{Bairro Mirante do Buquirinha em São José dos Campos}

Observa-se nas imagens da página 76 (figura 9), respectivamente, as inundações datadas de 11 de fevereiro de 2009 e 2 de janeiro de 2013, as quais desalojaram mais de 150 pessoas e a inundação datada de 16 de janeiro de 2016 no bairro Mirante do Buquirinha.

A ocupação indevida nas áreas de várzea deste local (áreas de APP Área de Proteção Permanente) deu-se ao longo dos anos, pela força da especulação imobiliária em áreas de alto padrão, conduzindo a população de menor poder aquisitivo adquirirem suas residências clandestinamente. 
Uma razão pertinente para a ocorrência das inundações é o assoreamento da calha do leito do curso de água, dificultando ou reduzindo a vazão. Neste caso, a explicação deve ser encontrada à montante, no uso do solo que tenha levado à erosão deste e sedimentação de parte do mesmo na calha do curso de água em seus trechos de menor velocidade (meandros). O processo ocorre naturalmente, mas, neste caso, teria sido acelerado pela ação antropogênica.

A Defesa Civil de São José dos Campos iniciou em dezembro/2016 o Plano Preventivo da Defesa Civil (PPDC), também chamado de Operação Verão. Foi uma ação de gestão de risco com o propósito de preservar vidas e reduzir os danos humanos, materiais e ambientais causados pela chuva, muito comuns esta época do ano.

No bairro, uma equipe da Defesa Civil fez o monitoramento de índices pluviométricos, que indicaram a quantidade de chuva que atingiu determinada região. O município de São José dos Campos possui dez pluviômetros automáticos, instalados pelo Centro Nacional de Monitoramento e Alerta de Desastres Naturais (Cemaden), em áreas consideradas de risco.

A medição do nível de chuva é realizada todos os dias e o índice acumulado é calculado com base nos três últimos dias, que coloca um município em estado de atenção caso atinja volume de 80 milímetros em três dias (PIMENTEL, 2016). 
Figura 9: Área de inundações no Bairro Mirante do Buquirinha, em imagem do Google Earth e três exemplos de ocorrências: ano de 2009, 2013 e 2016

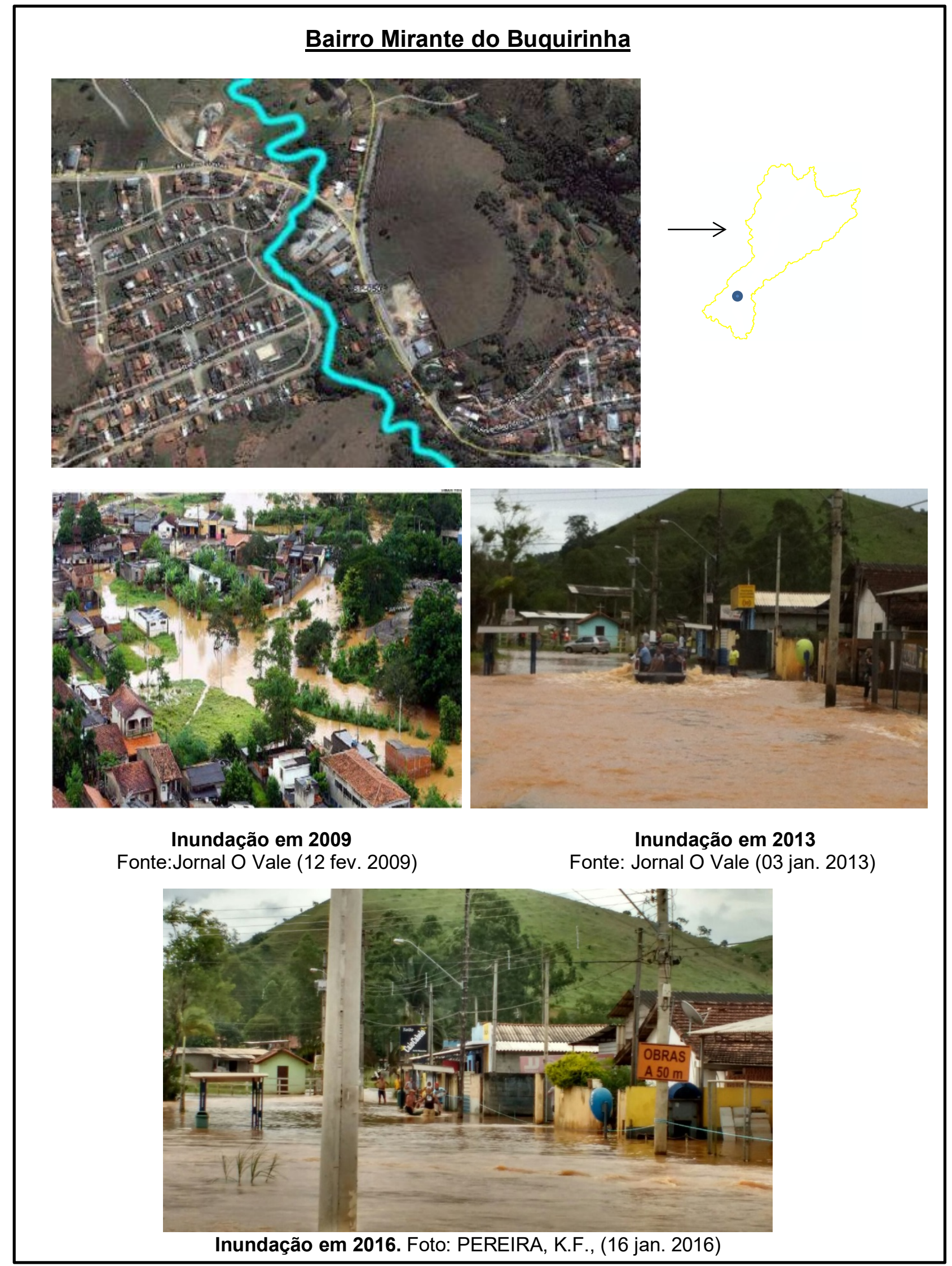

Fonte: Trabalho de campo 
A seguir, o registro fotográfico da inundação mais recente nesta área

(figura 10)

Figura 10: Série de fotos sobre a inundação do dia 16 de janeiro de 2016.

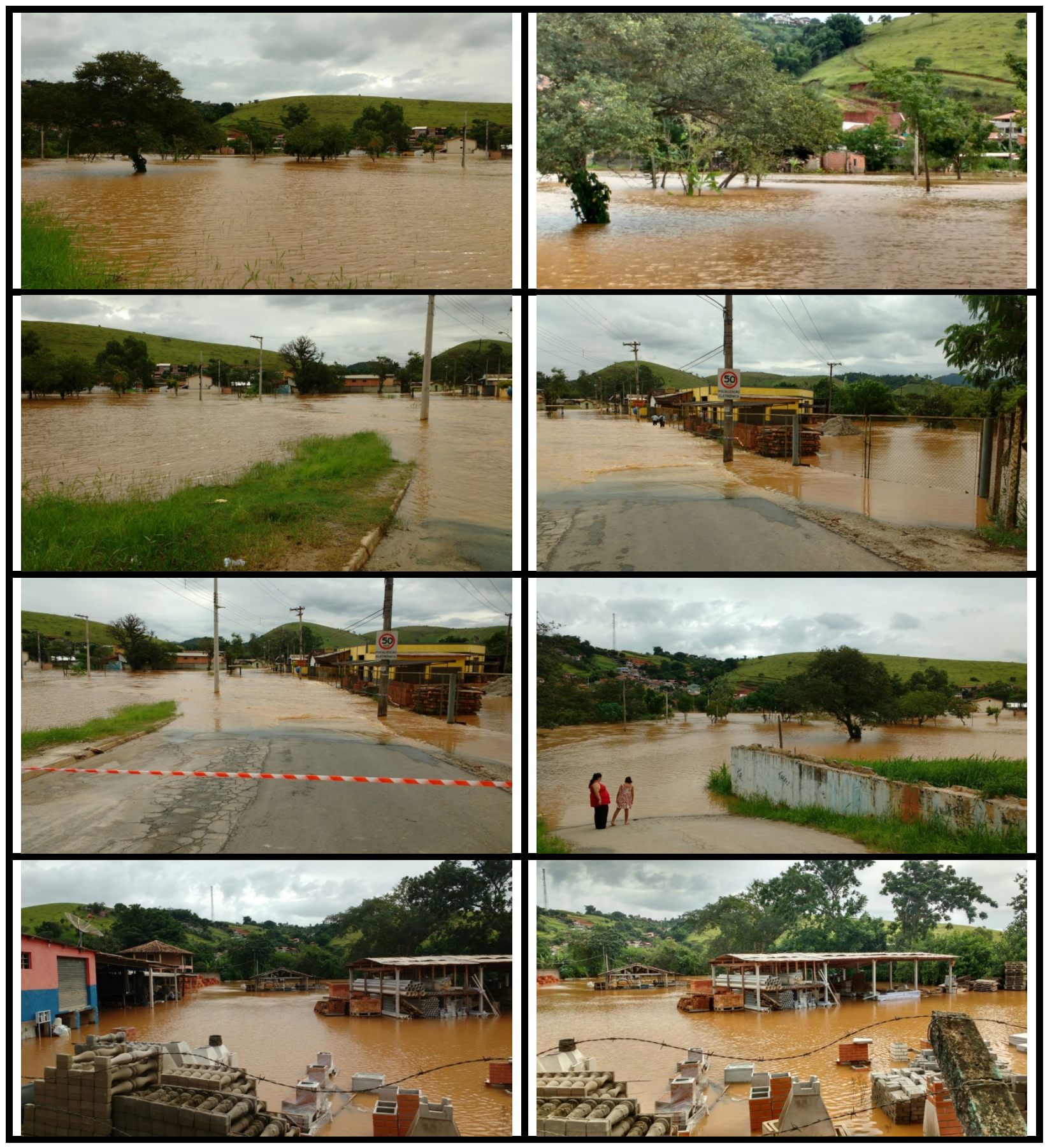




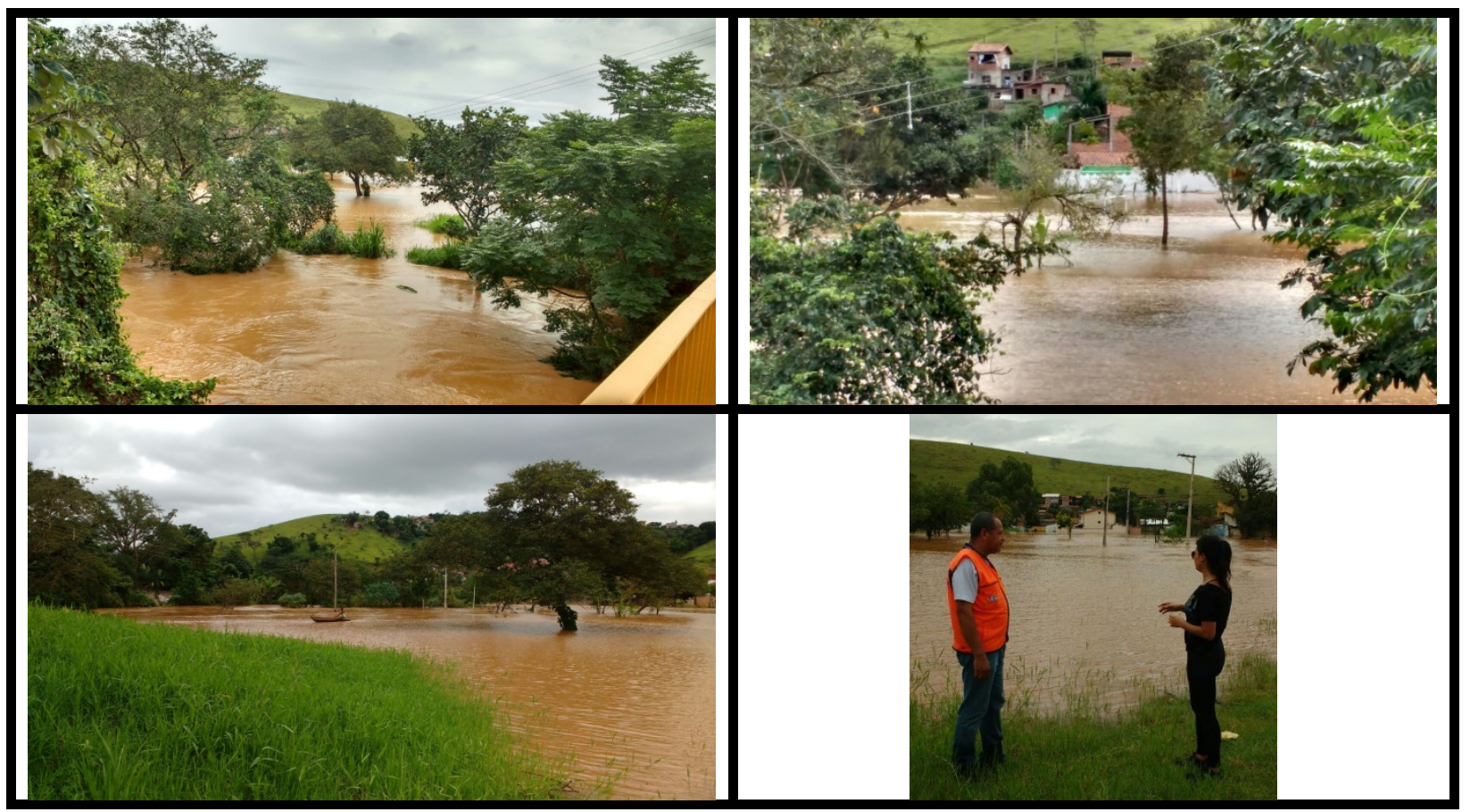

Fonte: Trabalho de campo Fotos: PEREIRA, K.F. (16 jan. 2016)

Este ponto apresenta, ainda, problemas ambientais que podem vir a contribuir para o agravamento do quadro ambiental.

A seguir apresentamos algumas fotos da área da bacia hidrográfica:

Figura 11: Rio Buquira, apresentando a preservação de sua mata ciliar

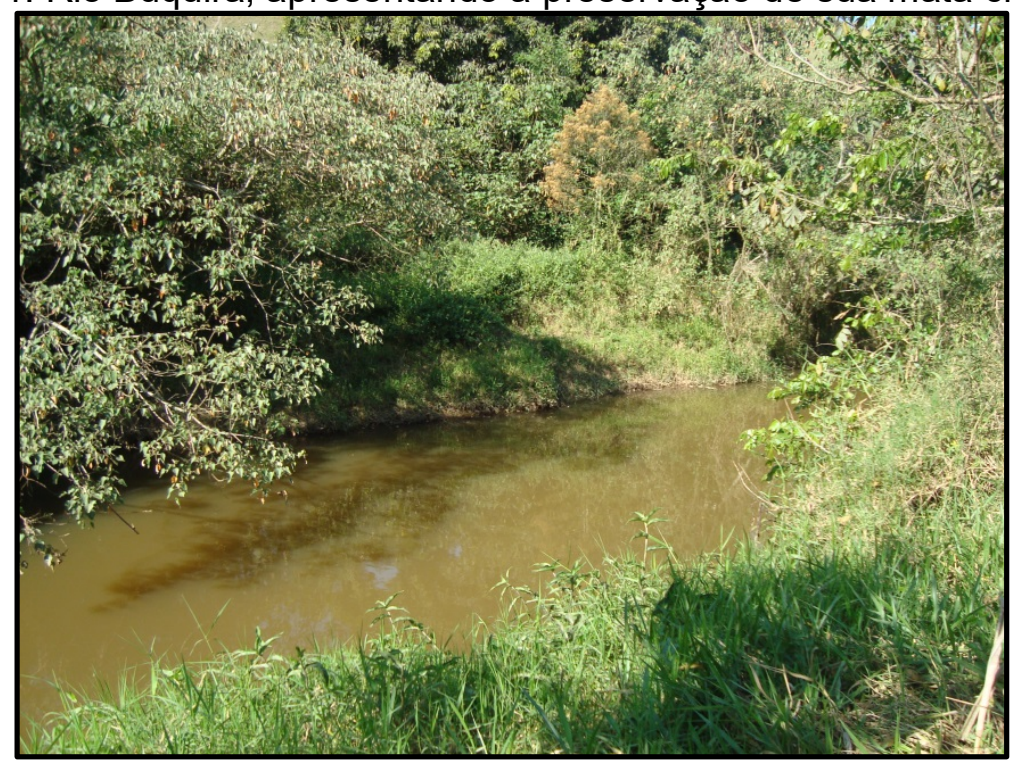

Foto: PEREIRA, K. F. (19 set. 2015) 
Figura 12: Ponte na SP-50, próximo ao curso d'água

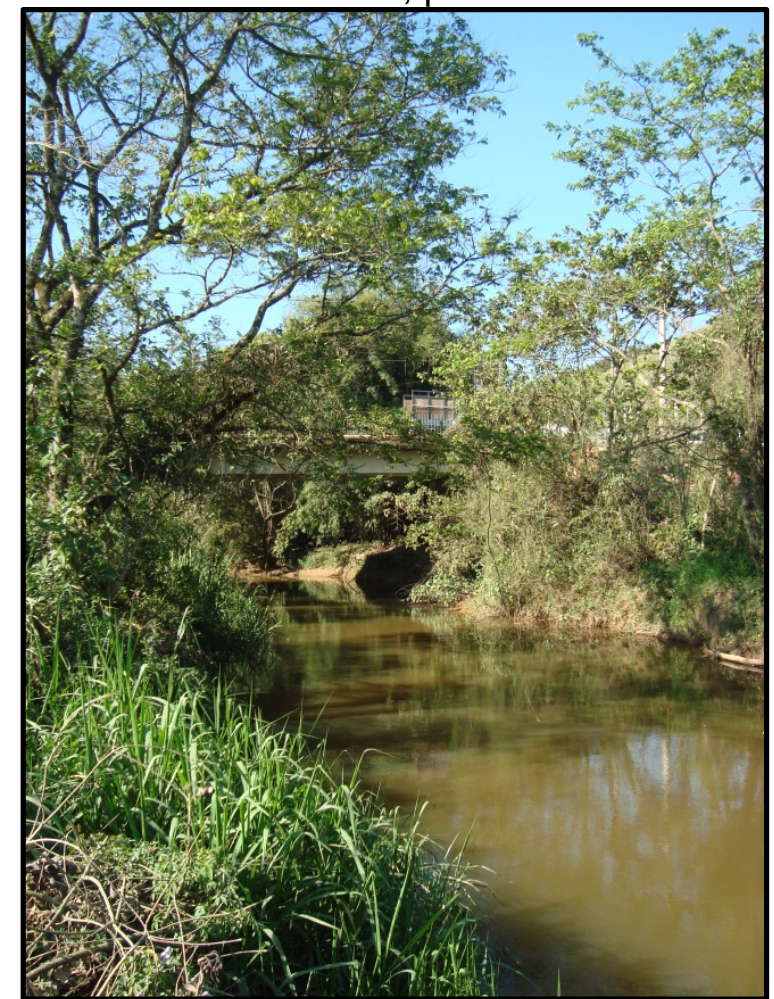

Foto: PEREIRA, K. F. (19 de set. 2015)

Figura 13: Assoreamento do Rio Buquira

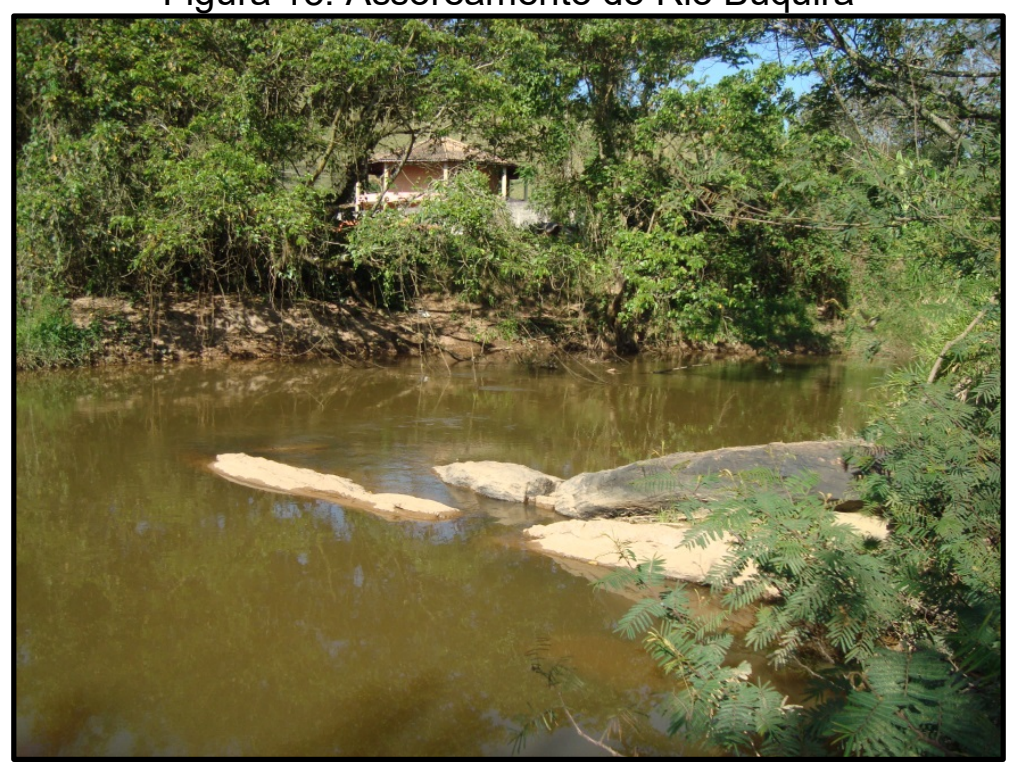

Foto: PEREIRA, K. F. (19 de set. 2015)

Figura 14: Disposição inadequada de lixo no entorno aos corpos d'água 


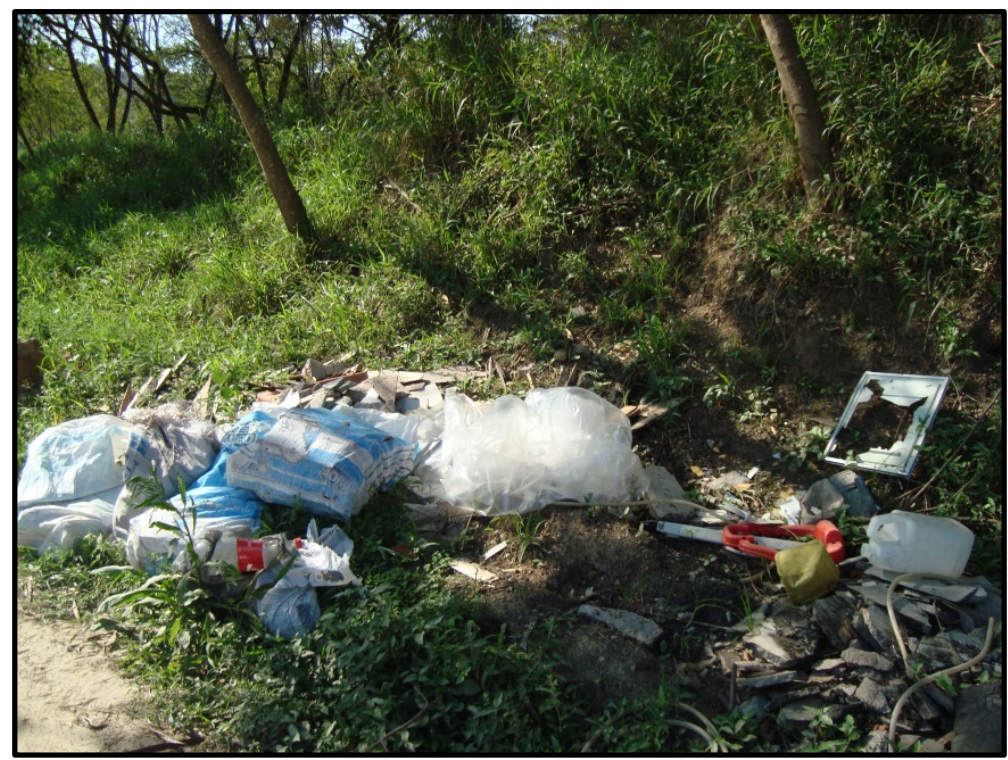

Foto: PEREIRA, K. F. (19 de set. 2015)

Figura 15: Lançamento de esgotos domésticos no leito do rio Buquira

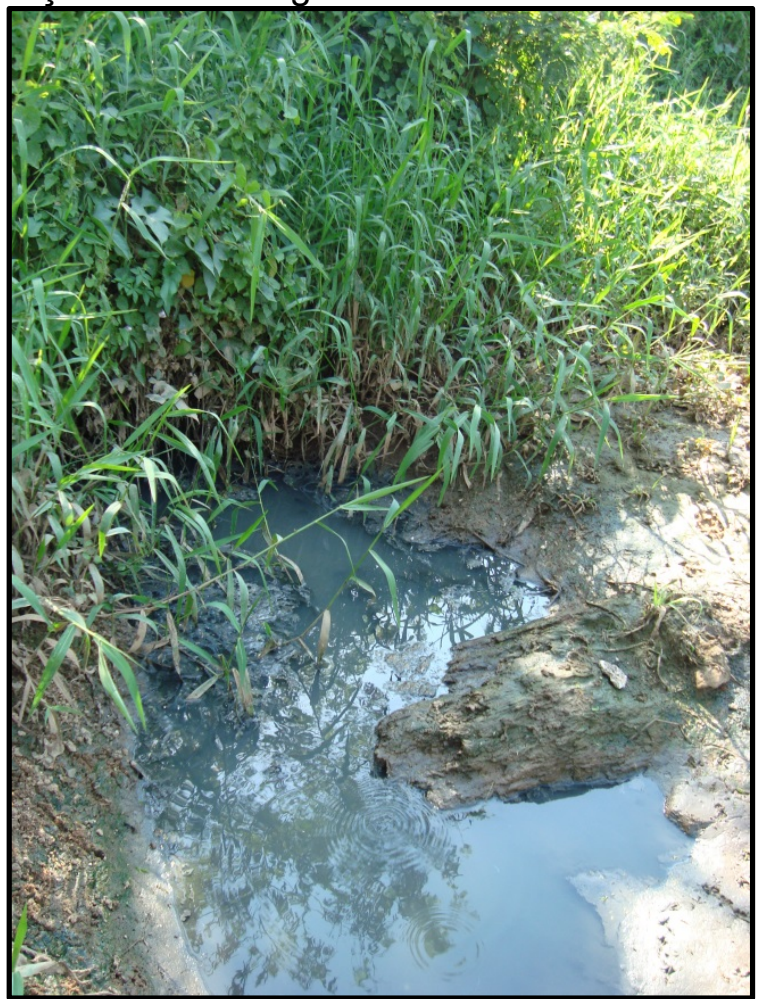

Foto: PEREIRA, K. F. (19 de set. 2015) 
Figura 16: Desocupação parcial da margem direita do rio.

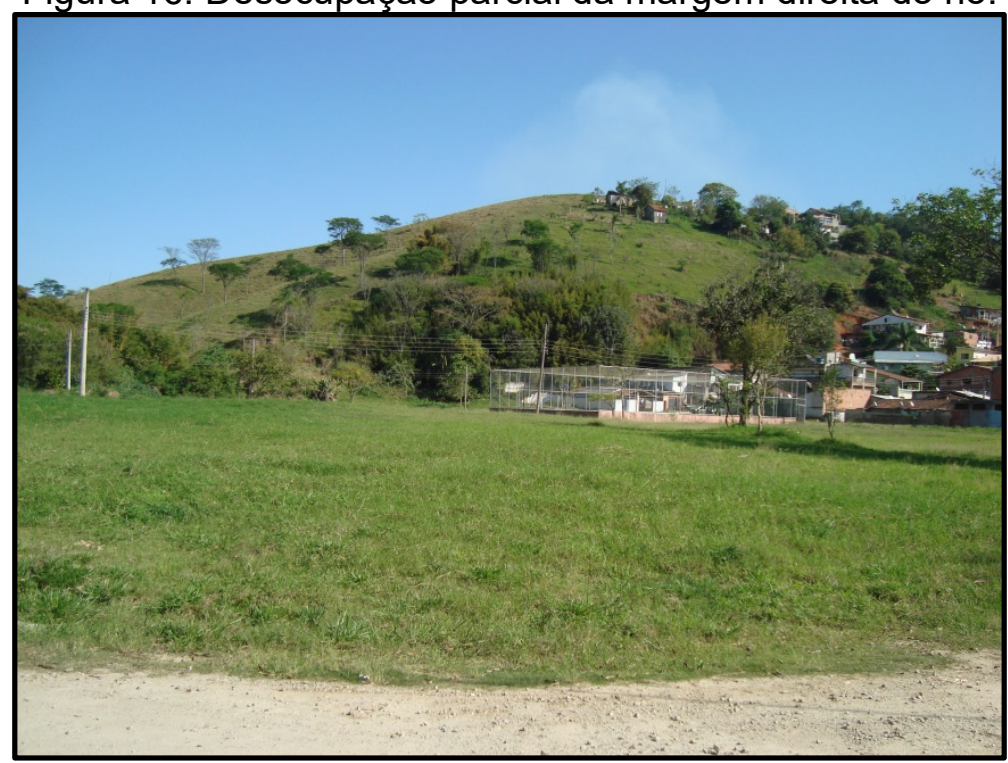

Foto: PEREIRA, K. F. (19 de set. 2015)

Figura 17: Margem esquerda do rio ainda ocupada

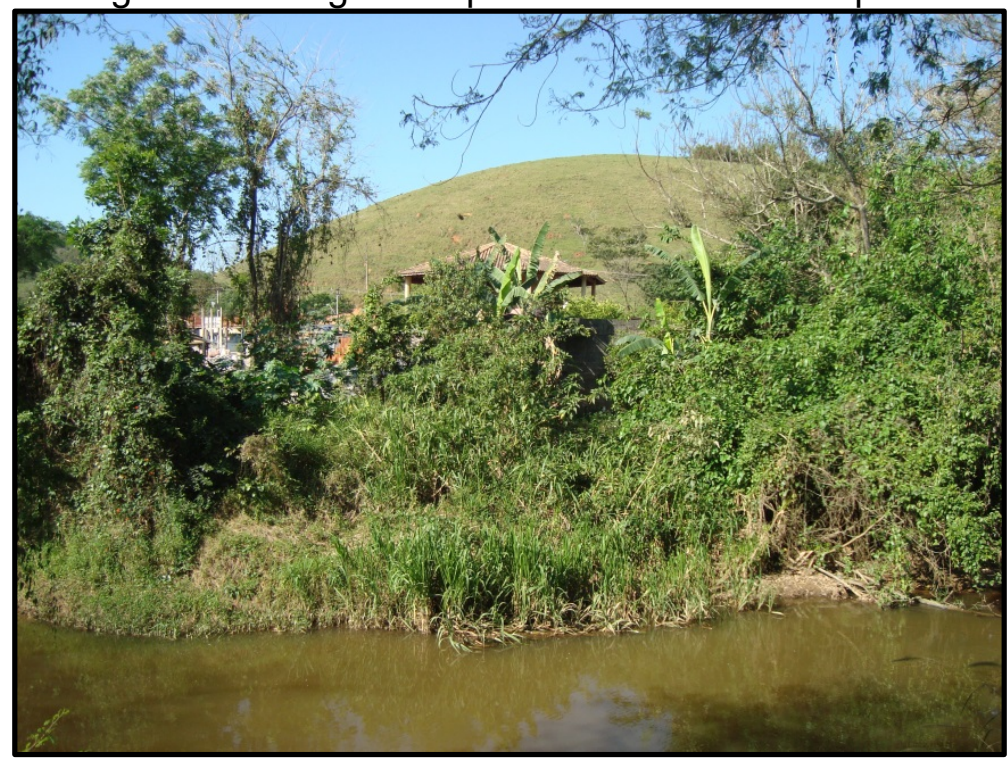

Foto: PEREIRA, K. F. (19 de set. 2015) 


\section{CAPÍTULO III}

\section{Caracterização da Bacia hidrográfica}




\subsection{Inventário da Bacia Hidrográfica do Rio Buquira (Monteiro Lobato - SP)}

A Bacia Hidrográfica do Rio Buquira (figura 18) faz parte da Bacia Hidrográfica do Rio Paraíba do Sul (UGRHI-02), que banha os estados de São Paulo, Rio de Janeiro e Minas Gerais. O Rio Paraíba do Sul percorre cerca de 1150 km a partir da nascente na Serra da Bocaina (SP) até sua foz, no município de São João da Barra (RJ).

Figura 18: Mapa da Divisão Político-administrativa: Bacia Hidrográfica do Rio Buquira

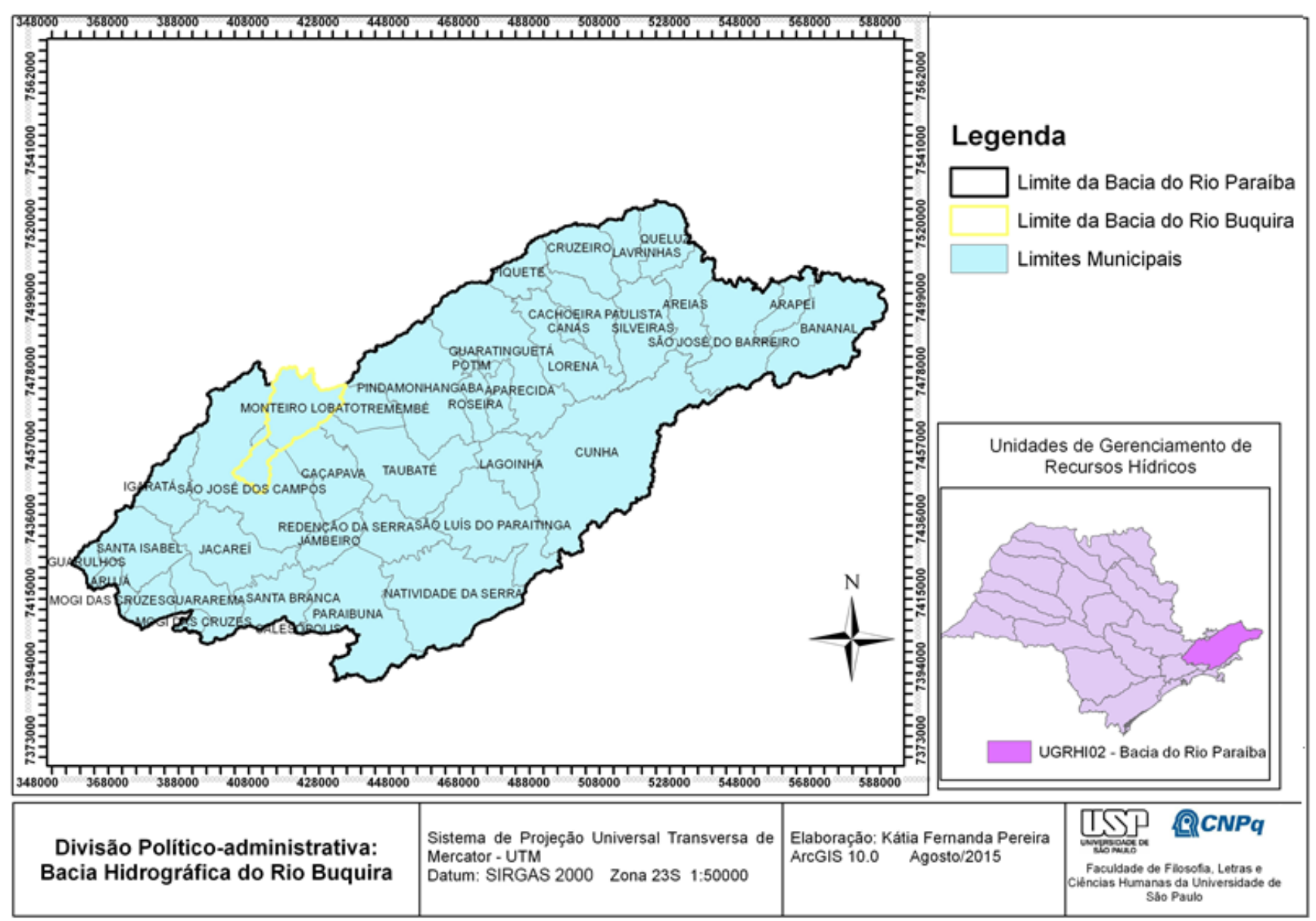

Fonte: Autora

A bacia do Buquira abrange os municípios de São José dos Campos e Monteiro Lobato, ambos localizados na Unidade de Gerenciamento de Recursos 
Hídricos - UGRHI 02. O Rio Buquira nasce na Serra da Mantiqueira, desaguando na região Norte de São José dos Campos, no bairro Vila Cândida.

Seus principais tributários são: rio Buquirinha, Ribeirão de Santa Maria, Rio Descoberto, Ribeirão do Miranda, Ribeirão dos Souzas e Rio Manso. 
84

Figura 19: Mapa base da Bacia Hidrográfica do Rio Buquira - Monteiro Lobato (SP)

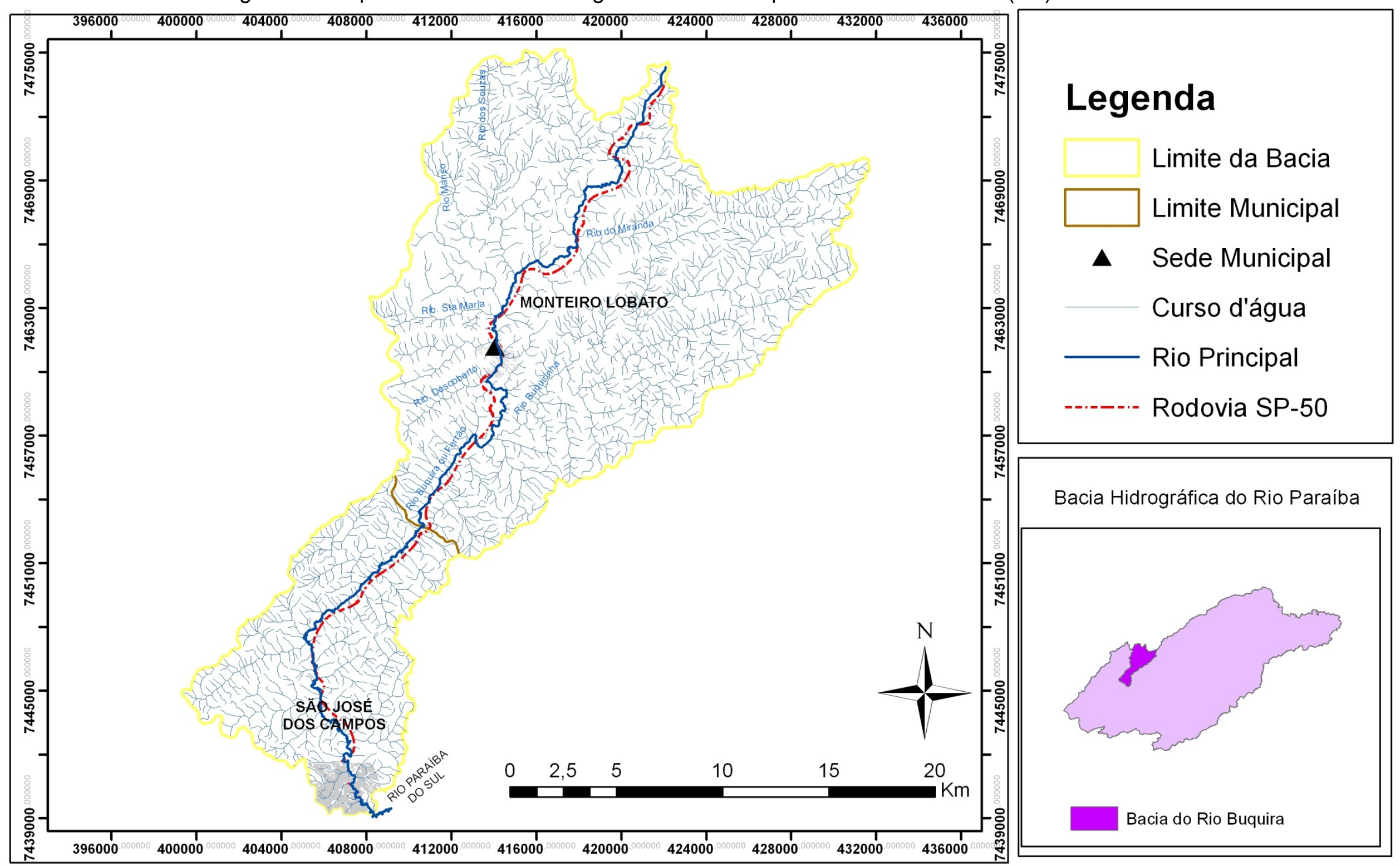

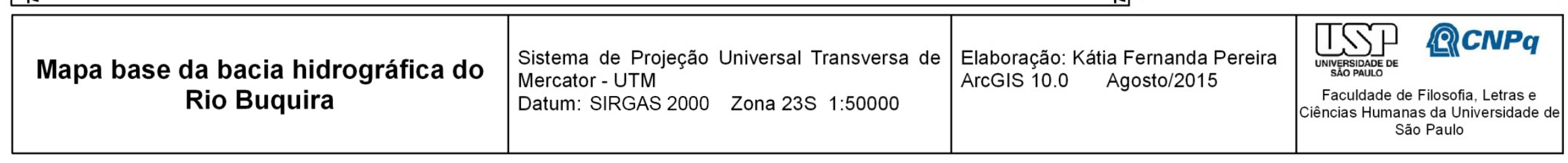


Sobre o Buquira e a Serra da Mantiqueira:

\begin{abstract}
A Serra da Mantiqueira, na porção que se desenvolve a Leste do rio Buquira (à altura de Monteiro Lobato), está próxima da bacia terciária, caindo sobre ela quase abruptamente, sem níveis intermediários, oferecendo poucas possibilidades à fixação de cidades: a única que aí se implantou, Piquete, aproveitou pequena planície de fundo de vale, ficando completamente anichada entre as elevações cristalinas. Em compensação, a Mantiqueira fornece, nesse trecho, magnífico pano de fundo para as cidades do vale médio, constituindo parte integrante do cenário, por exemplo, de Lorena e de Cruzeiro. A Oeste do rio Buquira, a Mantiqueira se apresenta rebaixada, com frente recuada, desdobrando-se em vários níveis, tendo, à sua frente, toda uma área amorreada; as condições oferecidas à implantação de centros urbanos são mais favoráveis, aí se encontrando três centros - Santa Isabel, Igaratá e Monteiro Lobato. (MÜLLER, 1969, p. 228)
\end{abstract}

De acordo com dados demográficos provenientes do IBGE, elaboramos tabela comparativa (tabela 1) referente aos municípios de Monteiro Lobato (cujo município encontra-se quase totalmente inserido na área da bacia) e São José dos Campos (onde somente a Zona Norte está inserida). Notadamente, São José dos Campos destaca-se em números:

Tabela 1: Tabela de informações sobre Monteiro Lobato e São José dos Campos.

\begin{tabular}{|c|c|c|}
\hline Dados & Monteiro Lobato & São José dos Campos \\
\hline População estimada 2015 (1) & 4.467 & 688.597 \\
\hline População 2010 & 4.120 & 629.921 \\
\hline Domicílios recenseados & 2.291 & 214.506 \\
\hline Área da unidade territorial $\left(\mathrm{km}^{2}\right)$ & 332,742 & $1.099,41$ \\
\hline Densidade demográfica (hab/ $\mathrm{km}^{2}$ ) & 12,38 & 572,96 \\
\hline Abastecimento de Água - Volume de água tratada distribuída por dia & $431 \mathrm{~m}^{3}$ & $153739 \mathrm{~m}^{3}$ \\
\hline $\begin{array}{l}\text { Abastecimento de Água - Número de economias abastecidas, de economias ativas abastecidas } \\
\text { e de domicílios }\end{array}$ & 733 & 180.468 \\
\hline Bioma & Mata Atlântica & Mata Atlântica \\
\hline Gentílico & lobatense & joseense \\
\hline IDHM 2010 & 0,71 & 0,807 \\
\hline PIB per capita a preços correntes - 2013 & $11.540,71$ & $40.699,31$ \\
\hline
\end{tabular}

FONTE: IBGE, 2010 
Figura 20: Evolução Populacional do Município de São José dos Campos (1940-2010)

\section{EVOLUÇÃO POPULACIONAL DO MUNICÍPIO DE SÃO JOSÉ DOS CAMPOS 1940-2010}

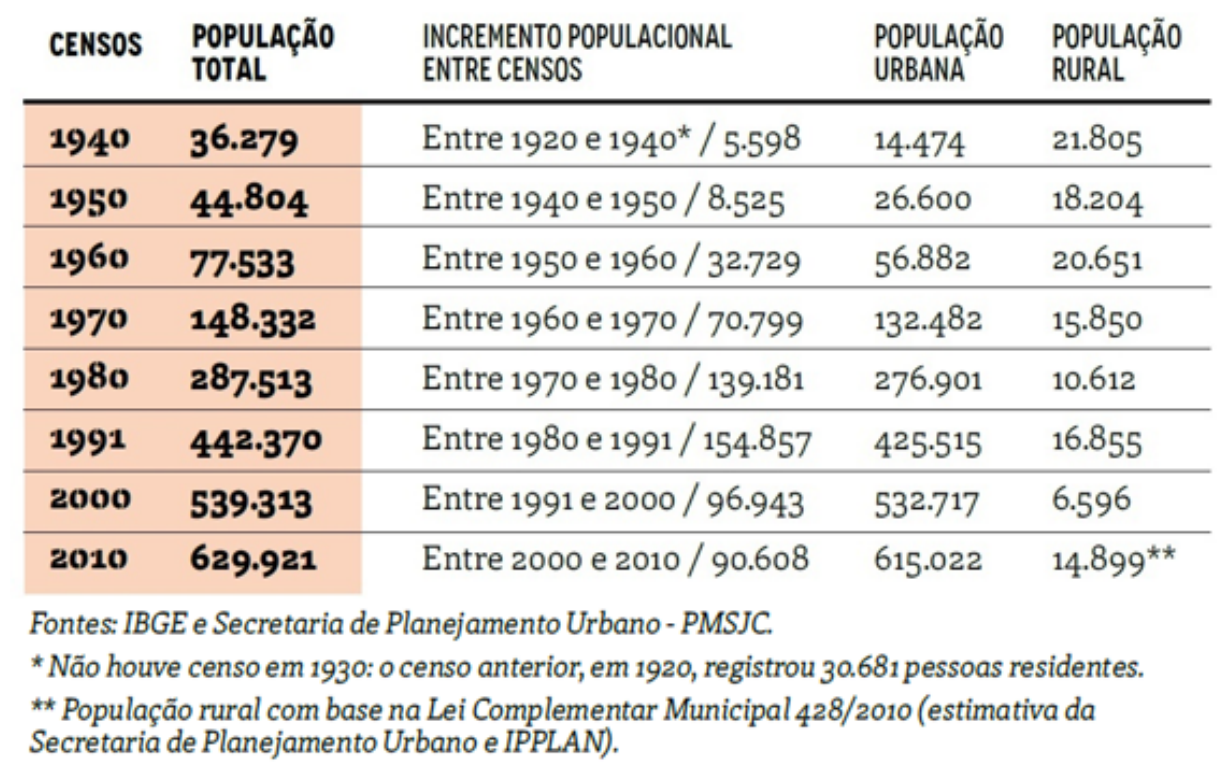

Fonte: São José em Dados - 2016, p. 49

Em se tratando dos dados demográficos referentes à área da bacia em São José dos Campos - Região Norte - segundo o Censo de 2010 do IBGE, a área possui 17.646 residências e 59.800 moradores, resultando em uma média de 3,38 hab/res. Possui 59 bairros.

Tendo em vista que a maior parte da bacia encontra-se no município de Monteiro Lobato, consideramos dados importantes ao elaborarmos este Inventário Ambiental: a) seu índice de Avaliação Ambiental; b) a carga orgânica doméstica recebida pelo Rio Buquira; c) o lançamento de efluentes e sua representatividade no Estado de São Paulo e d) a suscetibilidade à erosão/escorregamentos na área da bacia (tabela 2): 
Tabela 2: Índice de Avaliação Ambiental - IAA de Monteiro Lobato

\begin{tabular}{|c|c|c|c|c|c|c|c|c|c|c|}
\hline \multirow[b]{2}{*}{ Municipios } & \multicolumn{7}{|c|}{ Parâmetros Selecionados } & \multirow[b]{2}{*}{$\begin{array}{l}\text { Nota } \\
\text { final }^{(2)}\end{array}$} & \multirow[b]{2}{*}{$\begin{array}{c}\text { Posicăo } \\
\text { no } \\
\text { Estado }\end{array}$} & \multirow[b]{2}{*}{$\begin{array}{l}\text { Posicão } \\
\text { relativa na } \\
\text { UGRHI } 02\end{array}$} \\
\hline & $\begin{array}{l}\text { Esgoto } \\
\text { Tratado }\end{array}$ & $\begin{array}{l}\text { Lixo } \\
\text { Mínimo }\end{array}$ & $\begin{array}{l}\text { \% Area } \\
\text { Cobertura } \\
\text { Vegetal }\end{array}$ & $\begin{array}{c}\text { Educação } \\
\text { Ambiental - } \\
\text { Lei }\end{array}$ & $\begin{array}{c}\text { Arborizaçäo } \\
\text { Urbana - Lei } \\
\text { novos } \\
\text { parcel. }\end{array}$ & $\begin{array}{c}\text { Uso da } \\
\text { Agua - Lei }\end{array}$ & $\begin{array}{l}\text { Passivo I } \\
\text { Pendências }\end{array}$ & & & \\
\hline Monteiro Lobato & 0,87 & 7,50 & 27,21 & 0,00 & 0,00 & 0,00 & 2,00 & 57,8 & 345 & 10 \\
\hline
\end{tabular}

Fonte: IPT, 2014. Organizado pela autora

Sendo que o tratamento de esgotos é considerado um dos piores níveis da UGRHI 02 e onde não são cumpridos os parâmetros de Educação Ambiental, Arborização Urbana e Uso da Água, previstos em Lei.

Para complementar a deficiência do esgoto tratado, a carga poluidora nos corpos d'água apresenta a posição regular de 5,3, quase abaixo do nível aceitável, como observado na tabela 3 :

Tabela 3: Carga orgânica poluidora de origem doméstica em Monteiro Lobato

\begin{tabular}{|c|c|c|c|c|c|c|c|c|}
\hline \multirow{2}{*}{ Município } & \multirow{2}{*}{ Concessäo } & \multicolumn{3}{|c|}{ Atendimento (\%) } & \multicolumn{2}{|c|}{$\begin{array}{l}\text { Carga Poluidora } \\
\text { kg DBO }\end{array}$} & \multirow{2}{*}{ ICTEM } & \multirow{2}{*}{ Corpo Receptor } \\
\hline & & Coleta & Tratam. & Eficiência & Potencial & Remanesc. & & \\
\hline Monteiro Lobato & SABESP & 87 & 87 & 65 & 97 & 60 & 5,3 & Rio Buquira \\
\hline
\end{tabular}

Fonte: IPT, 2014. Organizado pela autora.

Quanto ao lançamento de efluentes nos corpos d'água superficiais em domínio estadual, é o uso rural cujo apresenta maior representatividade, segundo o gráfico 1:

Gráfico 1: Lançamentos de efluentes em corpos d'água superficiais no município de Monteiro Lobato 


\section{Lançamentos de efluentes em seus determinados usos $(\mathrm{Qm} 3 / \mathrm{s})$}

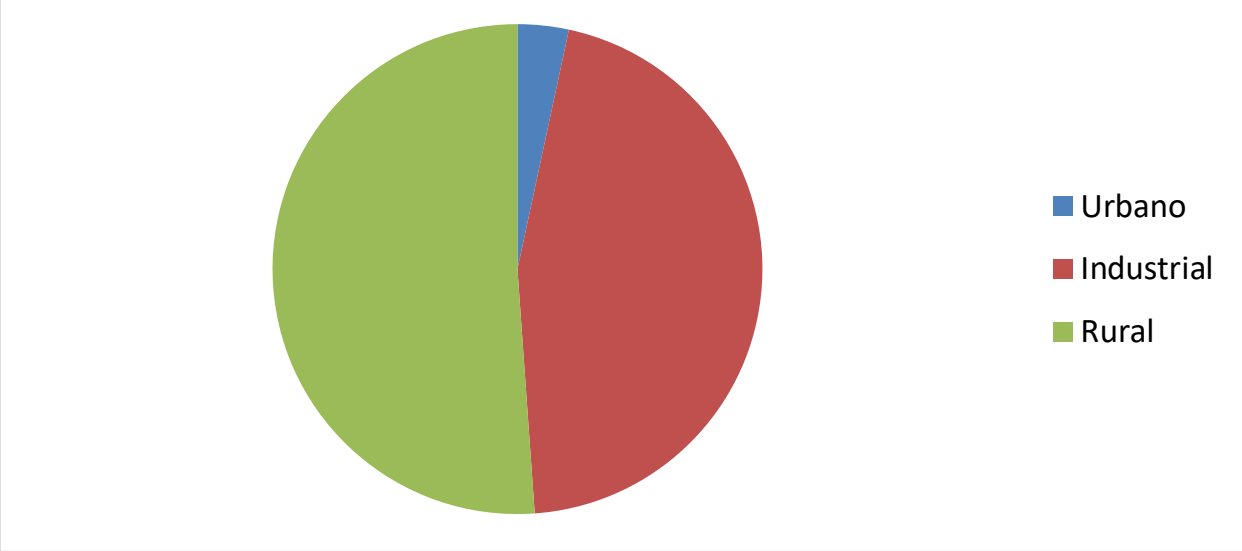

Fonte: IPT, 2014. Elaborado pela autora.

O total de lançamentos de efluentes representa $2,58 \%$ em domínio do Estado de São Paulo.

Para sinalizar um item importante na área da bacia, consideramos a alta suscetibilidade aos escorregamentos em Monteiro Lobato (gráfico 2), onde uma ação do Plano de Bacias seria elaborar o diagnóstico da situação da erosão e bairros rurais de Monteiro Lobato e diretrizes para controle:

Gráfico 2: Suscetibilidade à escorregamentos em Monteiro Lobato 


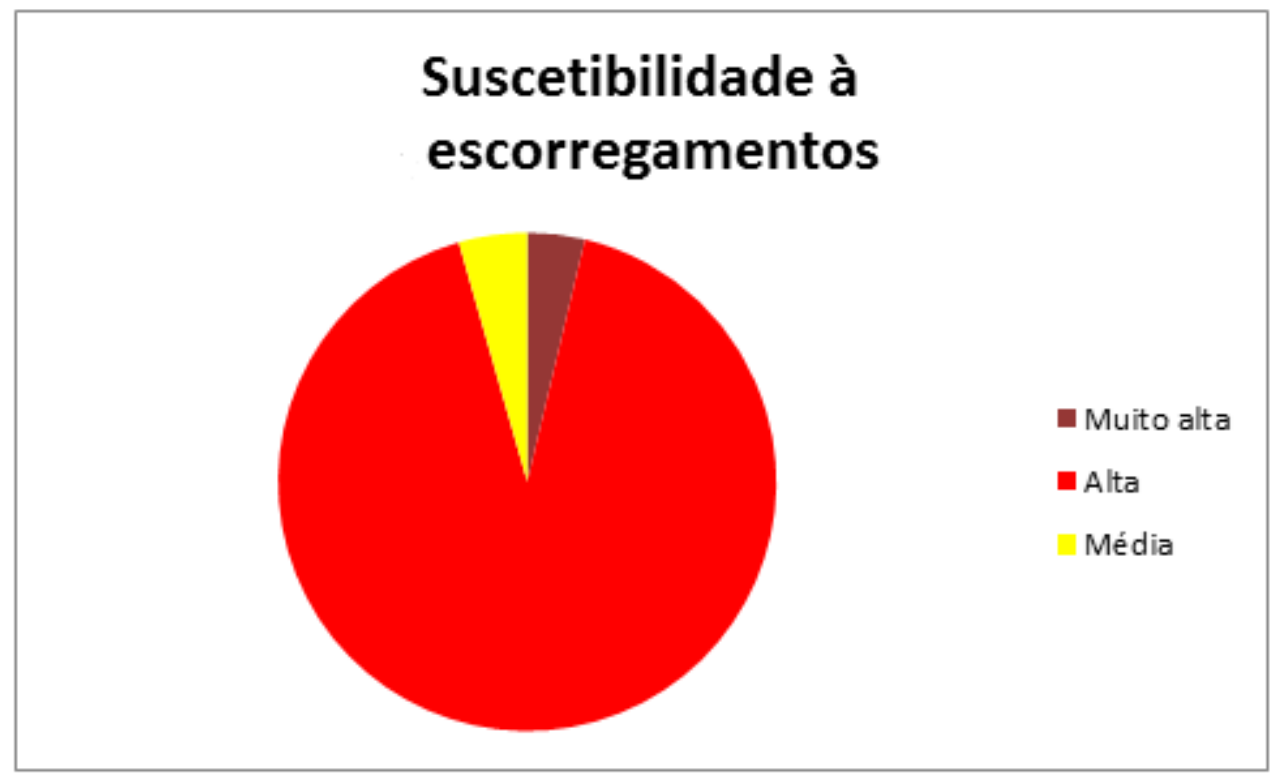

Fonte: IPT, 2014. Elaborado pela autora.

Assim, a proteção dos mananciais deve estar relacionada à conservação e recuperação da mata nativa para suporte à biodiversidade e estabilidade das encostas, já que a bacia possui consideráveis pontos de áreas de risco.

\subsubsection{Hipsometria}

Para a caracterização dos atributos físicos da bacia, a carta de hipsometria (figura 21) foi representativa para ilustrar a altimetria do terreno. Estas variam entre 560 metros à 1680 metros.

Nos trechos de maior altitude, observamos que as vertentes são muito inclinadas, como forte rugosidade topográfica. Nos trechos de altimetrias médias, as vertentes são ravinadas e os vales são entalhados e nas áreas mais baixas, as vertentes são ravinadas e os vales podem ser abertos ou fechados. 
Predominantemente, a bacia possui médias altitudes, entre 684 e 933 metros. 
Figura 21 - Carta Hipsométrica da Bacia Hidrográfica do Rio Buquira - Monteiro Lobato (SP)

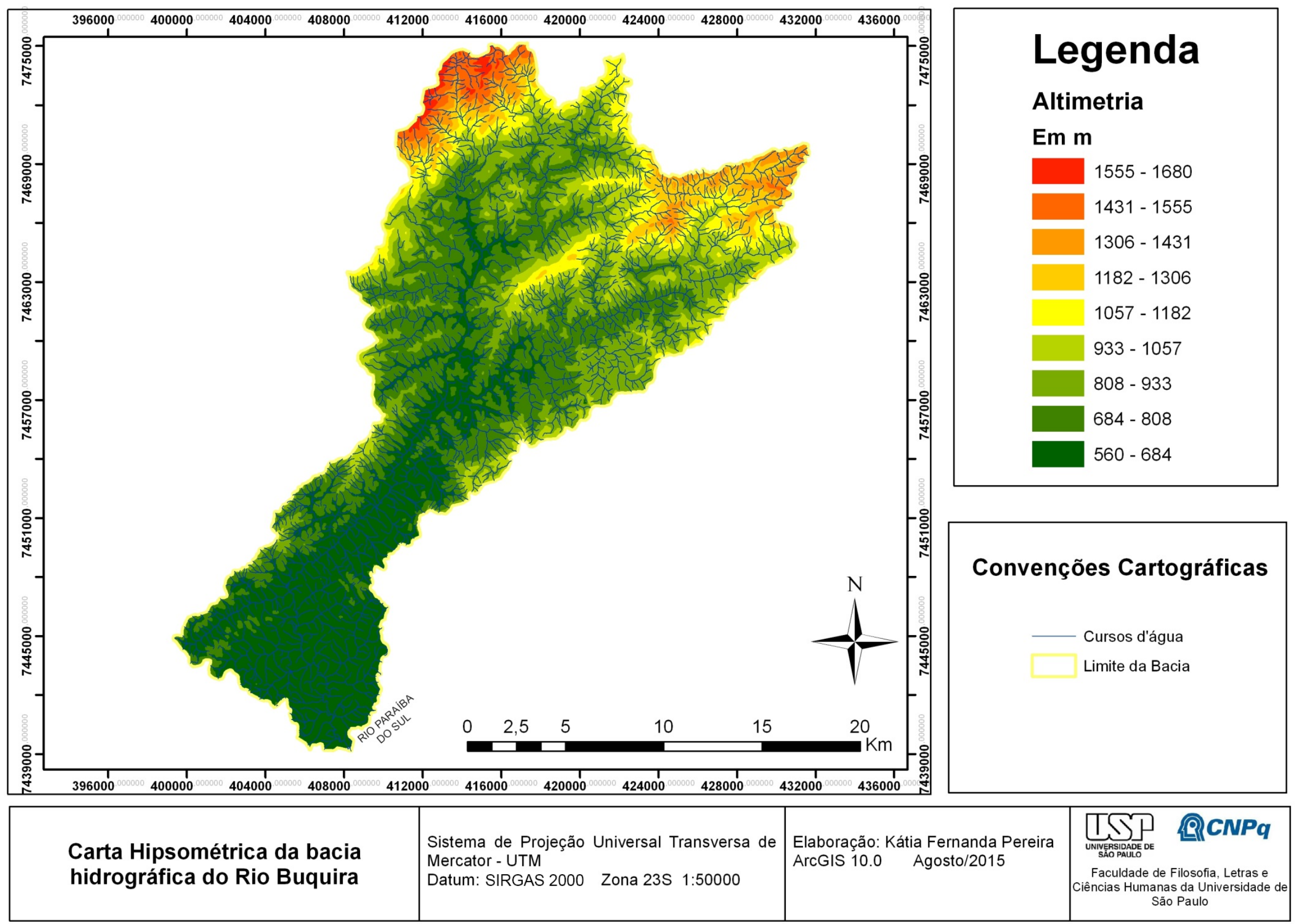




\subsubsection{Declividade}

Elaboramos a carta de declividades, com o intuito de apreender informações significativas sobre o relevo e disciplinar o uso e cobertura da área da bacia.

O grau de declive do terreno exerce influência direta sobre a quantidade de perda de solo por erosão, pois, quanto maior seu gradiente, maior a intensidade de escoamento das águas sob o efeito da gravidade, sendo, menor o seu tempo disponível para a infiltração no solo (Oliveira et al., 2007).

A carta clinográfica (figura 22) apresentou as declividades do terreno, nos pressupostos de Herz e Debiasi (1989) nas classes de: 0-5\%, 5-12\%, 12-30\%, $30-47 \%$, e $>47$. Segundo os autores,

$<-5 \%$ - Limite urbano - industrial, utilizados internacionalmente, bem com em trabalhos de planejamento urbano efetuados pelo Instituto de Pesquisas Tecnológicas do Estado de São Paulo e da EMPLASA - Empresa Metropolitana de Planejamento da Grande São Paulo S.A.

$5-12 \%$ - Este limite possui algumas variações quanto ao máximo a ser estabelecido (12\%), pois alguns adotam as cifras de $10 \%$ e / ou $13 \%$. A diferença é muito pequena, pois esta faixa define o limite máximo do emprego da mecanização na agricultura. (CHIARINI e DONZELLI, 1973).

12 - 30\% - O limite de 30\% é definido por legislação federal Lei 6766/79 - também chamada de Lei Lehmann, que vai definir o limite máximo para urbanização sem restrições, a partir do qual toda e qualquer forma de parcelamento far-se-á através de exigências específicas.

$30-47 \%$ - O Código Florestal, fixa o limite de $25^{\circ}$ (47\%), como limite de corte raso, a partir do qual a exploração só será permitida se sustentada por cobertura de florestas. Lei $\mathrm{N} .^{\circ}$ $4771 / 65$ de 15/09/65.

$>47 \%$ - O artigo 10 do Código Florestal prevê que na faixa situada entre $25^{\circ}(47 \%)$ a $45^{\circ}(100 \%)$, não é permitida a derrubada de florestas, ...só sendo tolerada a extração de toros, quando em regime de utilização racional, que vise a rendimentos permanentes. (HERS e DE BIASI in DE BIASI, 1992, p. 47) 
Onde, observando a carta elaborada, constatamos a evidência das declividades entre $30 \%$ e $47 \%$ e em menor escala, as declividades entre $5 \%$ e $12 \%$ : 
Figura 22: Carta Clinográfica da Bacia Hidrográfica do Rio Buquira - Monteiro Lobato (SP)

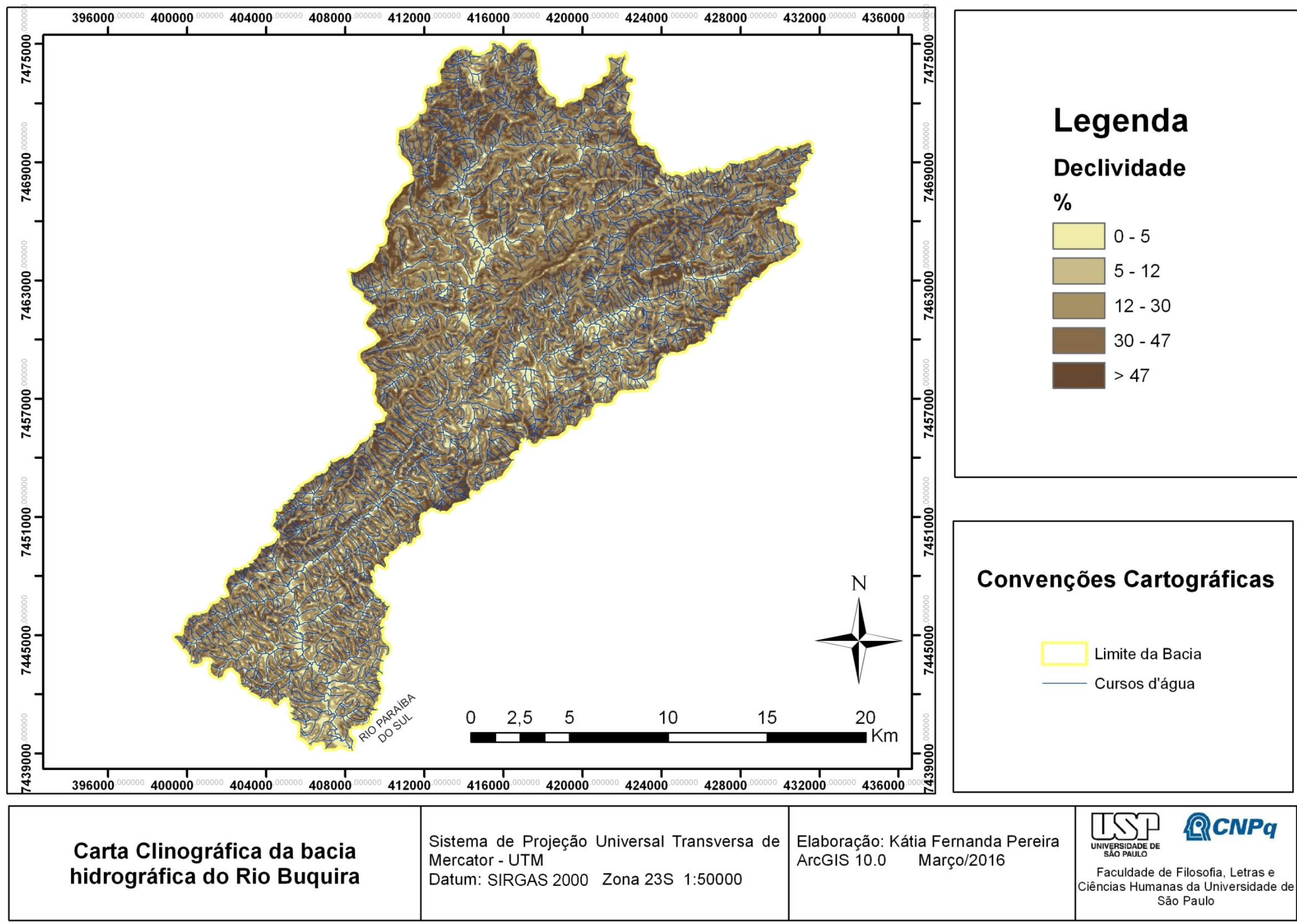


Portanto, a bacia possui, predominantemente, terras impróprias para mecanização em qualquer época do ano, com grandes restrições à ocupação humana, área considerável para o corte raso em áreas cobertas por mata, contudo, apresentando porções do território onde não se permite a derrubada das florestas.

\subsubsection{Geologia}

A geologia da área da bacia do Rio Buquira (figura 23) está relacionada à evolução do Vale do rio Paraíba do Sul, através de dois ciclos tectônicos: Ciclo Brasiliano e reativação Waldeniana (ROSS, 1990), posteriormente segmentando quatro períodos geológicos na Bacia: Neógeno, Cretáceo, Ediacariano e Criogeniano.

As unidades litológicas na área da bacia são: Granito Serra Preta, Granito Roncador, Serra do Trabiju, Granito Santa Isabel, Granito Serra do Palmital, São Francisco Xavier, São Roque do Boturuna, Embu - unidade de gnaisses bandados, Embu - unidade paragnáissica, Embu - unidade de xistos localmente migmatíticos, Varginha-Guaxupé - unidade paragnáissica migmatítica superior e depósitos aluvionares.

O paragnaisse é a forma litológica mais recorrente na bacia. 
Figura 23 Carta Geológica da Bacia Hidrográfica do Rio Buquira - Monteiro Lobato (SP)

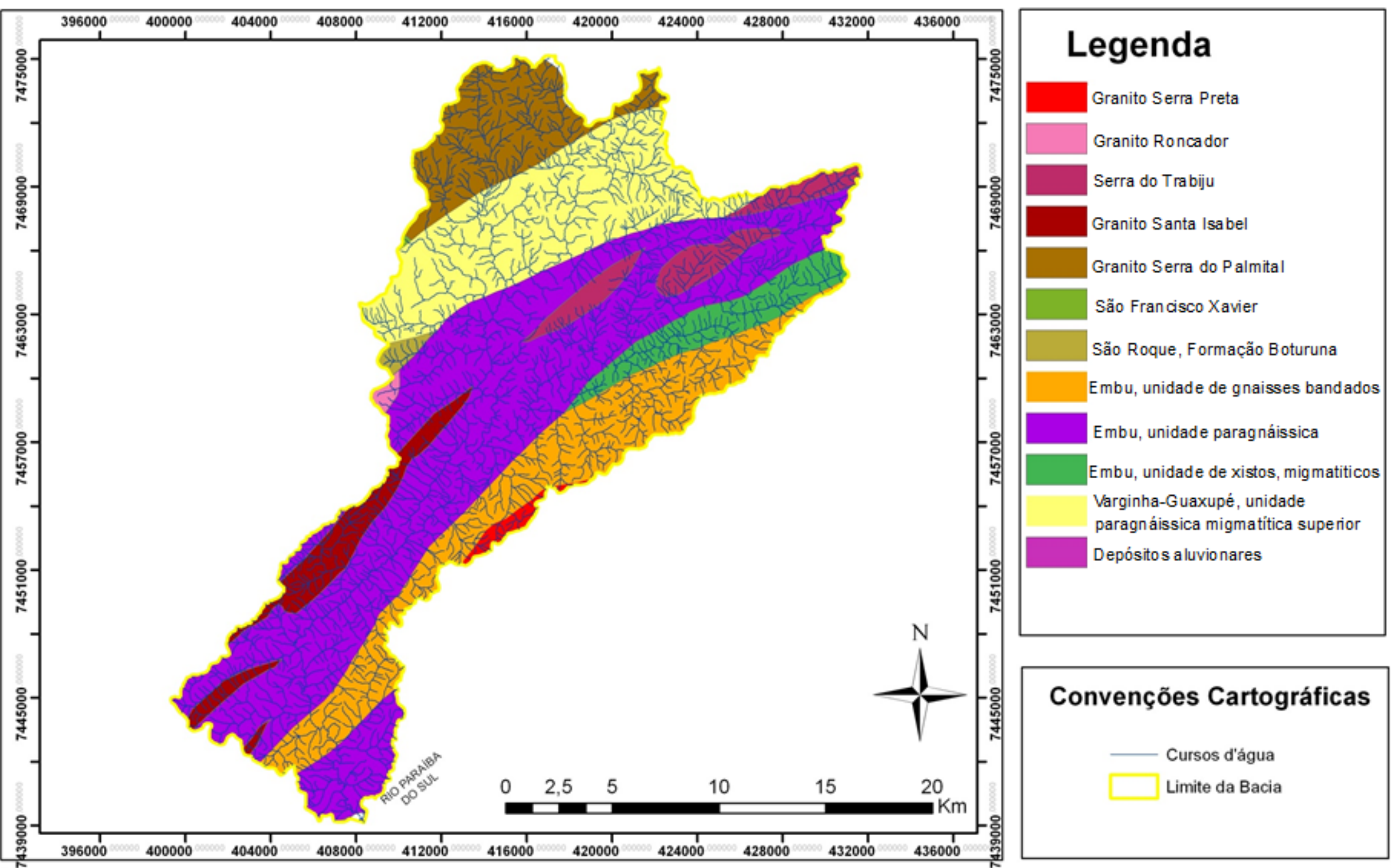

\begin{tabular}{|c|c|c|c|}
\hline $\begin{array}{c}\text { Carta Geológica da bacia hidrográfica } \\
\text { do Rio Buquira }\end{array}$ & $\begin{array}{l}\text { Sistema de Projeçăo Universal Transversa de } \\
\text { Mercator-UTM } \\
\text { Datum: SIRGAS } 2000 \text { Zona 23S 1:50000 } \\
\text { Fonte: Mapa Geológico do Estado de São } \\
\text { Paulo, São Paulo: CPRM, } 1997\end{array}$ & $\begin{array}{l}\text { Elaboração: Kátia Fernanda Pereira } \\
\text { ArcGIS 10.0 Setembro/2015 }\end{array}$ & 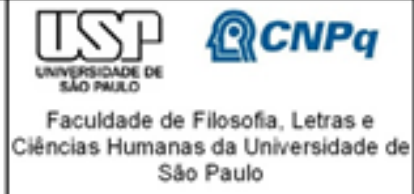 \\
\hline
\end{tabular}


Observando os perfis verticais e horizontais na área da bacia (figura 24), é notável as superfícies rebaixadas, inseridas em rochas Pré-cambrianas e limitadas pela Serra da Mantiqueira:

Figura 24: Perfis topográficos da Bacia Hidrográfica do Rio Buquira - Monteiro Lobato (SP)

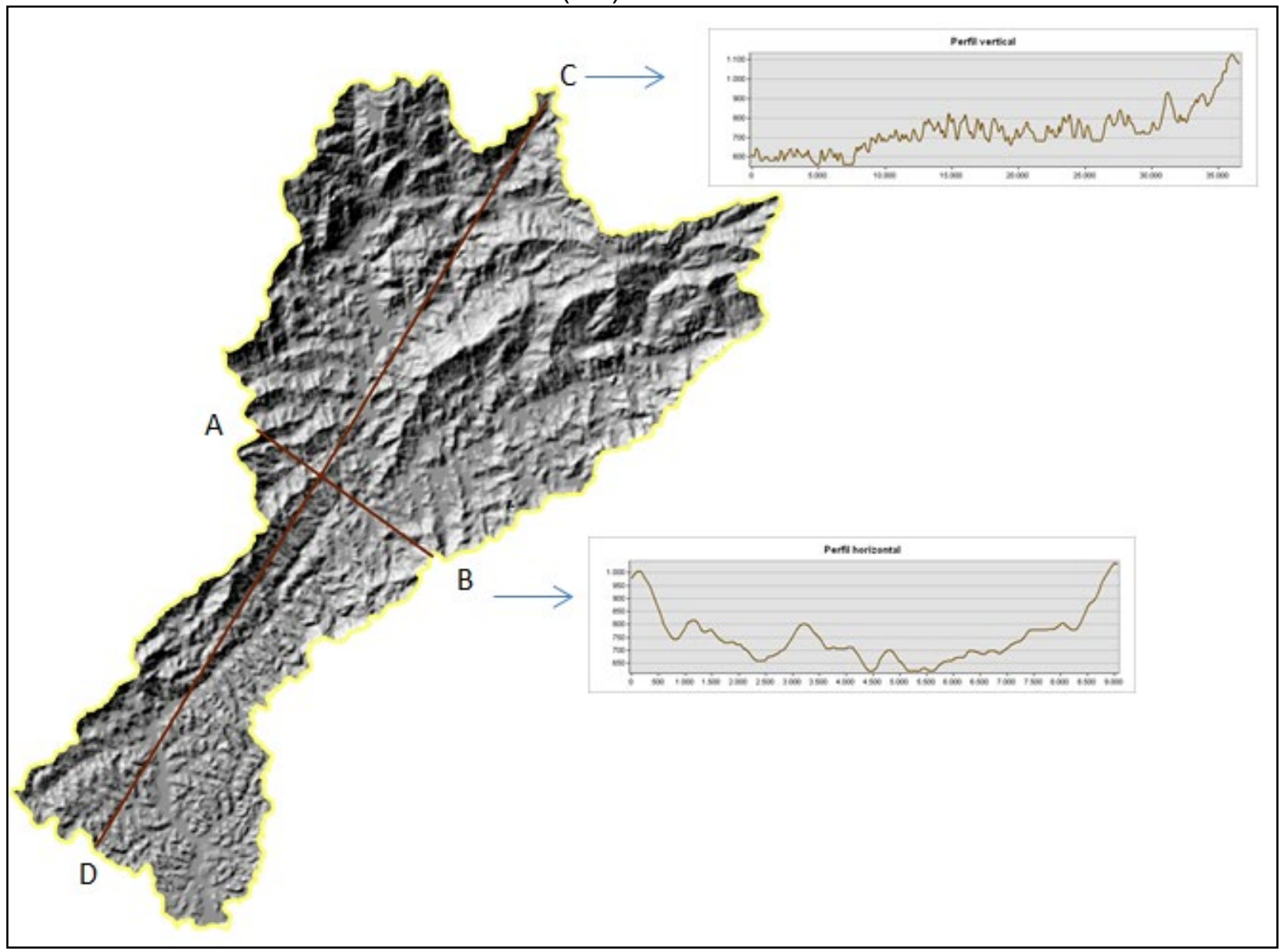

Fonte: Elaborado pela autora

\subsubsection{Pedologia}

A figura 25 apresenta o tipo de solos da região da Bacia, onde as classes dividem-se, segundo OLIVEIRA, 1999 (revisado e ampliado por ROSSI, 2017) em: argissolos, cambissolos, gleissolos, latossolos e neossolos. 
A maior extensão se dá na presença dos latossolos vermelho-amarelos.

Geralmente são bastante porosos com alta fragilidade, favorecendo a agricultura e o uso de maquinário, exceto nas áreas de altas declividades. 
Figura 25: Carta Pedológica da Bacia Hidrográfica do Rio Buquira - Monteiro Lobato (SP)

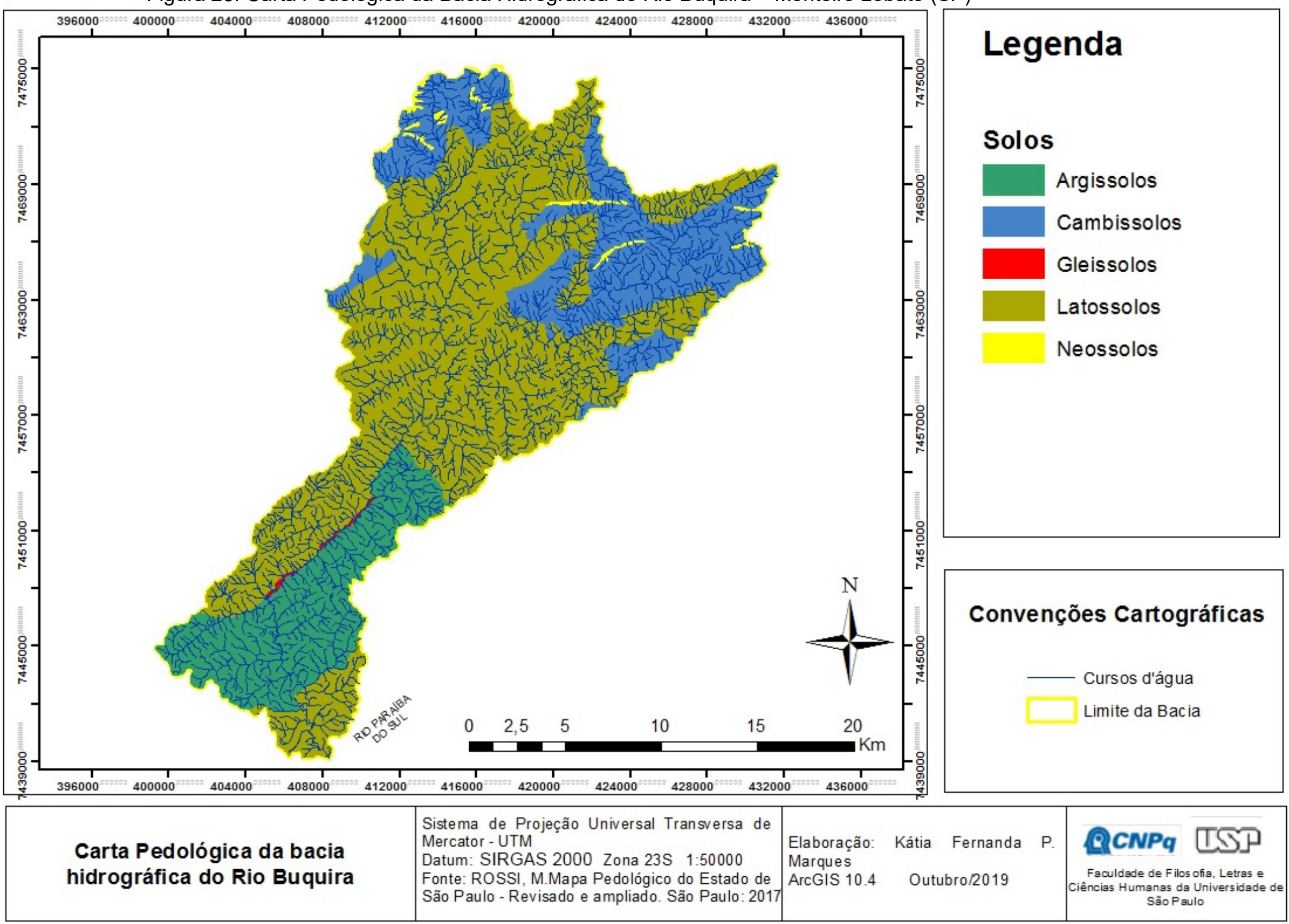




\subsubsection{Geomorfologia}

$\mathrm{Na}$ ausência de uma carta de Geomorfologia em escala apropriada à utilizada nesta pesquisa, propusemos o mapeamento dos compartimentos geomorfológicos (mapa 26) através da matriz dos índices de dissecação relevo (ROSS et al, 1997) e da distribuição da morfoestrutura do Cinturão Orogênico do Atlântico, subdividido em Planalto e Serra da Mantiqueira, Planalto Paulista e Planalto do Médio Vale do Paraíba.

Os modelados dominantes localizados são as escarpas e morros altos, morros altos e médios e morros baixos. 
Figura 26: Carta dos Compartimentos Geomorfológicos da Bacia Hidrográfica do Rio Buquira - Monteiro Lobato (SP)

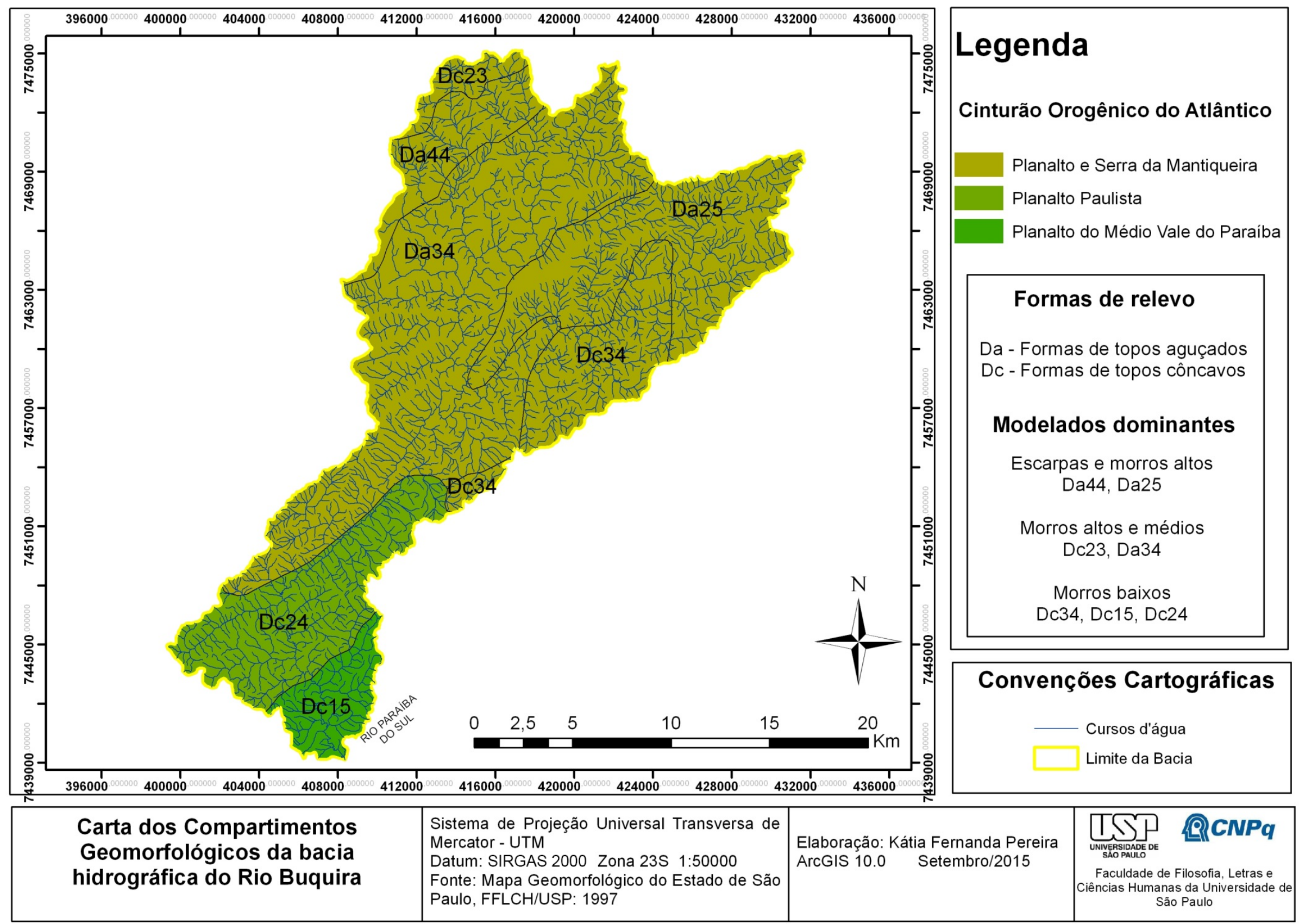


A matriz dos índices de dissecação do relevo (figura 27), para a representação dos compartimentos geomorfológicos na bacia é importante para quantificar o grau do trabalho fluvial na superfície da bacia, onde quanto mais dissecado, maior será a atividade fluvial no local.

Figura 27: Matriz dos índices de dissecação do relevo MATRIZ DOS INDICES DE DISSECAÇÃO DO RELEVO

\begin{tabular}{|c|c|c|c|c|c|}
\hline 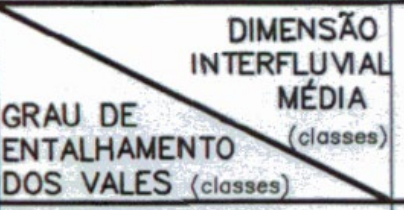 & $\begin{array}{l}\text { MUITO } \\
\text { GRANDE } \\
\text { (1) } \\
>3750 \mathrm{~m}\end{array}$ & $\begin{array}{c}\text { GRANDE } \\
(2) \\
1750 \mathrm{~m} \text { व } 3750 \mathrm{~m}\end{array}$ & $\begin{array}{c}\text { MédIA } \\
\text { (3) } \\
750 \mathrm{~m} \text { o } 1750 \mathrm{~m}\end{array}$ & $\begin{array}{l}\text { PEQUENA } \\
\text { (4) } \\
250 \mathrm{~m} \circ 750 \mathrm{~m}\end{array}$ & $\begin{array}{l}\text { MUITO } \\
\text { PEQUENA } \\
\text { (5) } \\
\leq 250 \mathrm{~m}\end{array}$ \\
\hline $\begin{array}{l}\text { MUITO FRACO (1) } \\
<20 \mathrm{~m}\end{array}$ & 11 & 12 & 13 & 14 & 15 \\
\hline $\begin{array}{l}\text { FRACO (2) } \\
20 \text { a } 40 \mathrm{~m}\end{array}$ & 21 & 22 & 23 & 24 & 25 \\
\hline $\begin{array}{l}\text { MÉDIO } \\
40 \text { a } 80 \mathrm{~m}\end{array}$ & 31 & 32 & 33 & 34 & 35 \\
\hline $\begin{array}{l}\text { FORTE (4) } \\
80 \text { a } 160 \mathrm{~m}\end{array}$ & 41 & 42 & 43 & 44 & 45 \\
\hline $\begin{array}{l}\text { MUITO FORTE (5) } \\
>160 \mathrm{~m}\end{array}$ & 51 & 52 & 53 & 54 & 55 \\
\hline
\end{tabular}

Fonte: Ross et al, 1997

Sendo que o menor valor numérico corresponde à dissecação mais fraca, ou seja, 11. O maior valor numérico é a dissecação mais forte, ou seja, 55.

De acordo com a análise da carta e sobreposição das demais cartas ambientais, observamos que os compartimentos geomorfológicos na bacia possuem um nível de fragilidade potencial médio, alto e muito alto, sendo que as áreas de média fragilidade são áreas sujeitas a voçorocas, áreas de alta fragilidade são as áreas sujeitas a processos erosivos agressivos, com probabilidade de movimentos de massa e erosão linear com voçorocas e as áreas de fragilidade muito alta são susceptíveis à processos erosivos agressivos, inclusive movimentos de massa. (ROSS et al, 1997). 


\subsubsection{Clima}

De acordo com a classificação climática de Köppen, a área da bacia é do tipo Cwa, caracterizado pelo clima tropical de altitude, com chuvas no verão e seca no inverno, com a temperatura média do mês mais quente superior a $22^{\circ} \mathrm{C}$.

Considerando a tipologia climática de Monteiro (1976), no contexto do Estado de São Paulo, utilizamos a concepção de que o Estado divide-se em duas zonas: intertropical e subtropical.

Para a área da bacia, observamos que esta se insere na zona climática controlada por massas equatoriais e tropicais. Segundo apreciação do mapa de Monteiro (1976) para o Estado, constatamos que ao Norte da bacia ocorrem as feições climáticas sob influência da Serra da Mantiqueira. O restante da bacia apresenta feições climáticas sob a influência do vale do Paraíba.

Conti (1975), em seu trabalho sobre a circulação secundária e os seus efeitos na gênese das chuvas na região lés-nordeste do estado de São Paulo, destaca o Médio Vale do Paraíba. Situada na zona intertropical, esta região merece determinada atenção no que tange os fenômenos pluviais e a circulação atmosférica geral, pois são os maiores agentes de interferência no meio físico e humano.

Neste estudo, Conti (1975) caracterizou a dinâmica climática do Vale do Paraíba como uma região com elevada frequência de calmarias e com a recorrência da Massa Tropical Atlântica na circulação secundária. Segundo o autor, a região apresenta uma morfologia movimentada, devido a presença da Serra do Mar e Mantiqueira, onde os sistemas atmosféricos ali alternam-se com grande mobilidade. 
As elevadas precipitações nesta área devem-se, além da forte incidência de radiação solar e evaporação, à sua topografia bastante acidentada.

No gráfico a seguir (figura 28), utilizamos dados provenientes do Instituto Nacional de Meteorologia para o ano de 2015 e região de Campos do Jordão, cuja estação convencional ativa é a mais próxima à área de estudo. Observamos, portanto, que a acumulação de chuvas foi distinta da acumulação de chuvas referente à normal climatológica. As estações do ano que se aproximaram às médias dos anos interiores condizem com o outono e inverno. Janeiro, que é um mês de forte incidência de chuvas na região, obteve pluviosidade menor para este ano de referência.

Figura 28: Gráfico de Chuva acumulada X Chuva acumulada mensal (normal climatológica) para o ano de 2015.

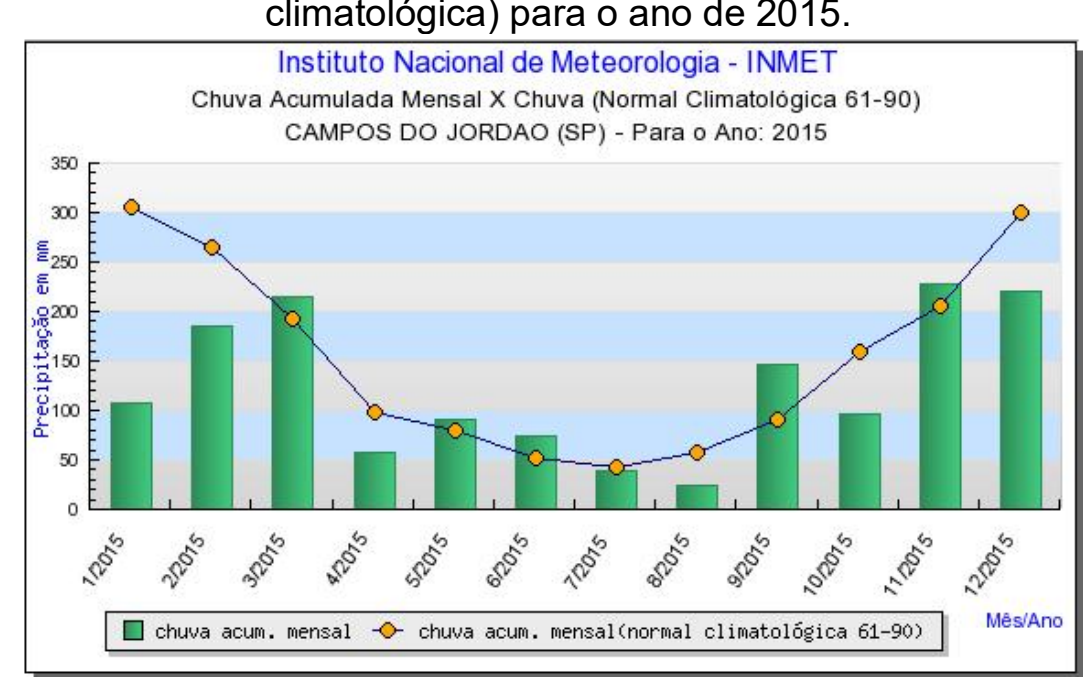

. Fonte: Instituto Nacional de Meteorologia (INMET). Elaborado pela autora 


\subsubsection{Uso e cobertura da terra}

O Vale do Paraíba possui distintamente quatro áreas importantes no Estado de São Paulo: destaca-se pelas áreas de nascentes, pelas áreas de reservatório, pelas áreas urbano-industriais e pelas áreas agrícola-urbano-industriais. (SOARES, 2007).

Originalmente, o Vale do Paraíba era coberto pela floresta tropical latifoliada, em quase toda a sua extensão, entretanto, devido aos diversos ciclos da agricultura (cana-de-açúcar e café), a paisagem regional passou por mudanças substanciais. Atualmente, as áreas rurais do Médio Vale do rio Paraíba do Sul vêm passando por transformações, no que concerne a introdução de plantios de eucalipto em antigas áreas de pastagem. A vegetação natural de Mata Atlântica, ainda hoje, apresenta extensas áreas conservadas.

A seguir, analisamos uma fotografia aérea da área urbana de Monteiro Lobato (figura 29) e a comparamos com uma imagem do Google Earth do ano de 2015 (figura 30).

Figura 29: Foto aérea do ano de 1962 da Bacia Hidrográfica do Rio Buquira 


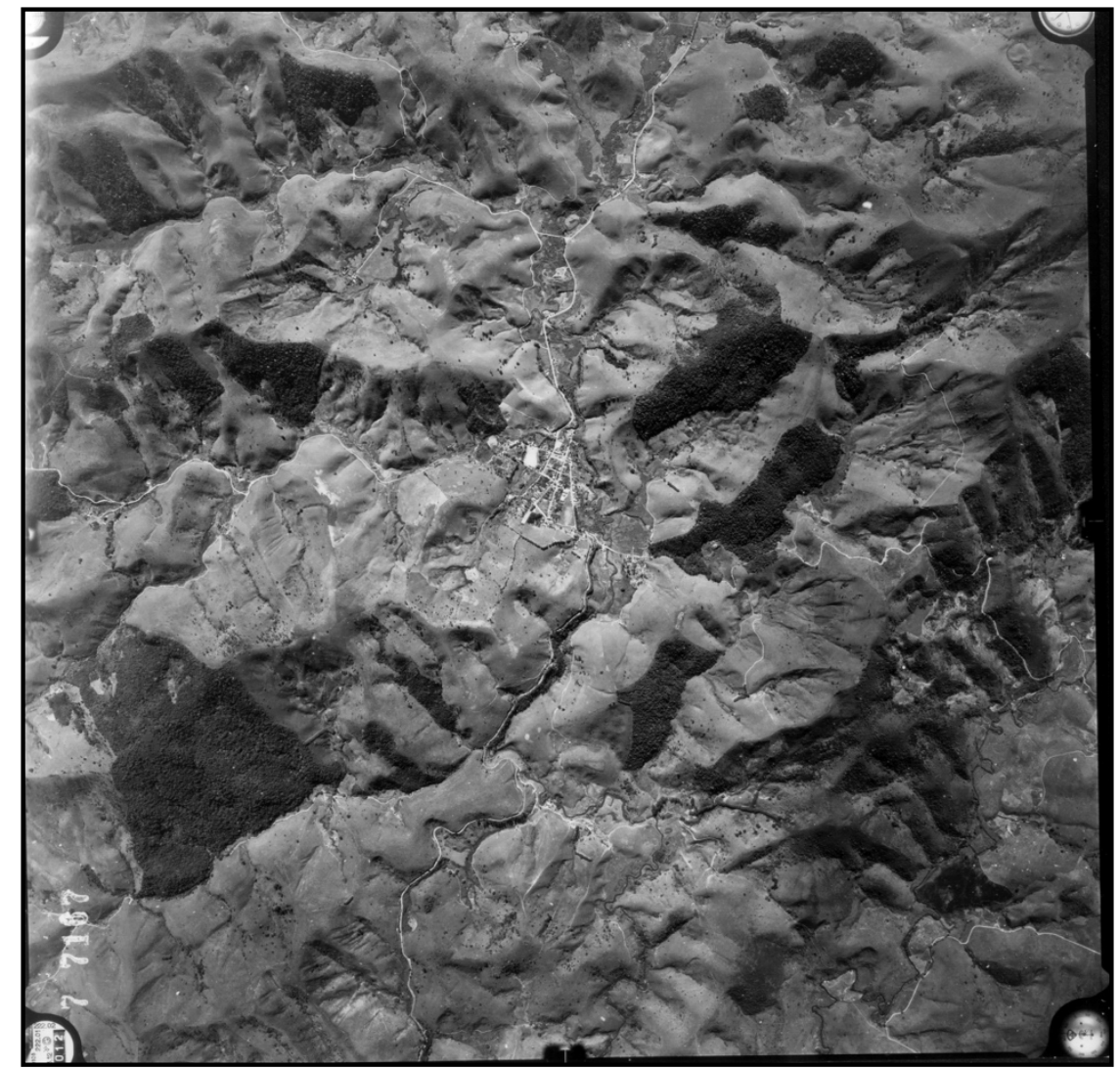

Fonte: Fotografia aérea de 1962/ IGC

Figura 30: Imagem do Google Earth de 2015 da Bacia Hidrográfica do Rio Buquira

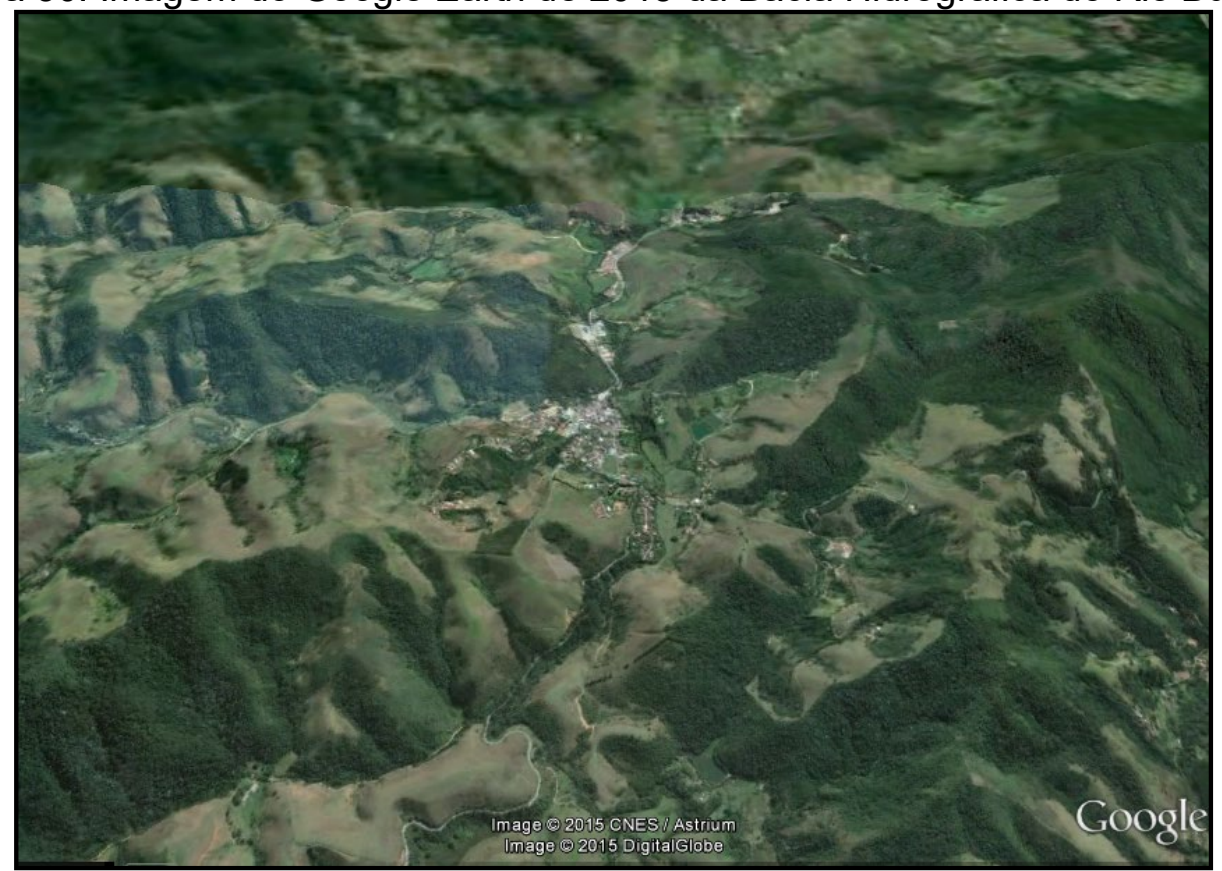

Fonte: Google Earth

Nas fotos, observa-se que a área urbana de Monteiro Lobato apresentou um crescimento considerável, bem como ao estabelecimento de áreas construídas 
próximas aos cursos d'água e, ainda, que a vegetação natural aumentou expressivamente, demonstrando traços de uma bacia conservada.

Para a interpretação das imagens de satélite Landsat foi utilizado um padrão de classificação das imagens, como representação na figura 31:

Figura 31: Chave de interpretação para imagens TM/lLandsat

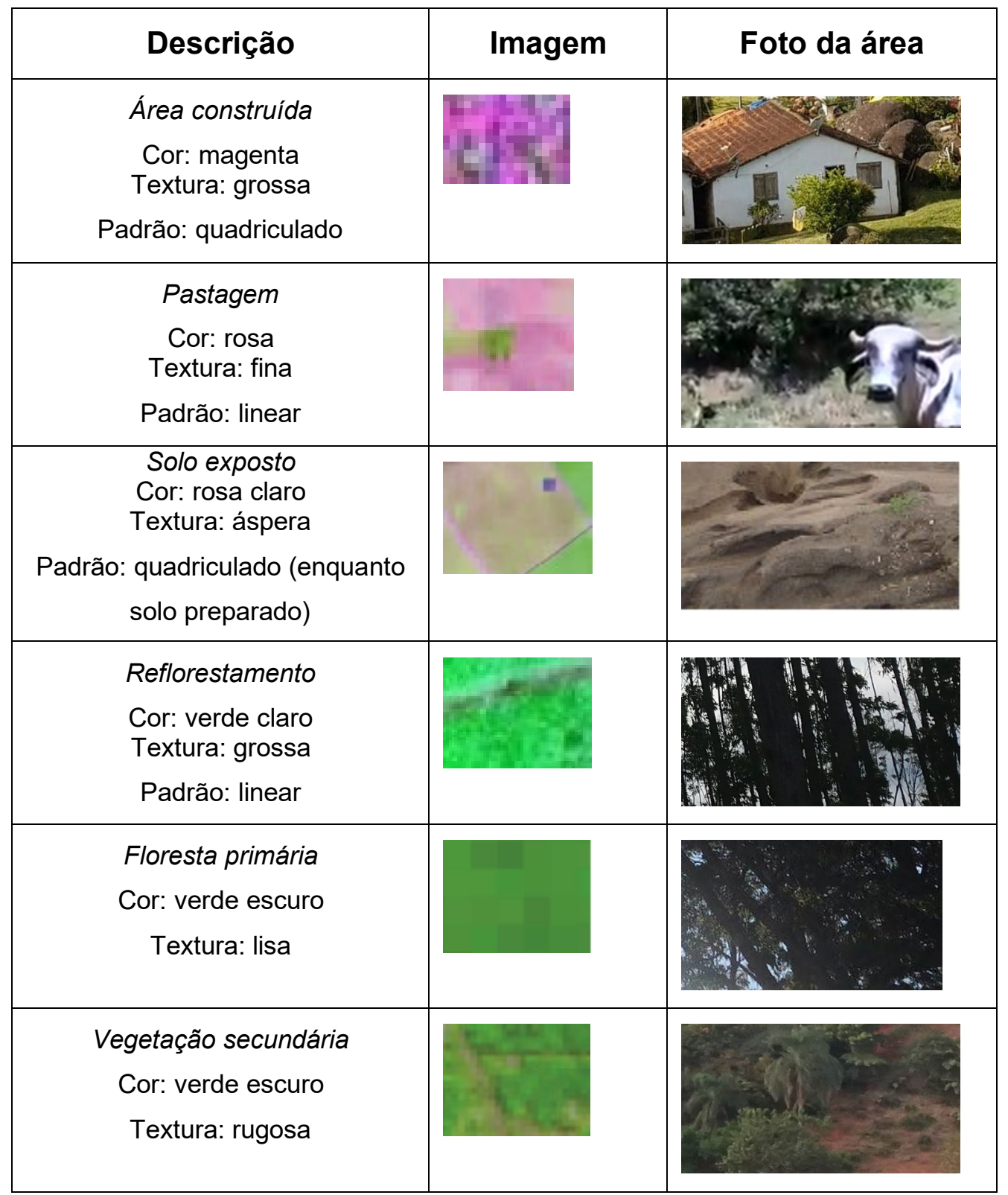




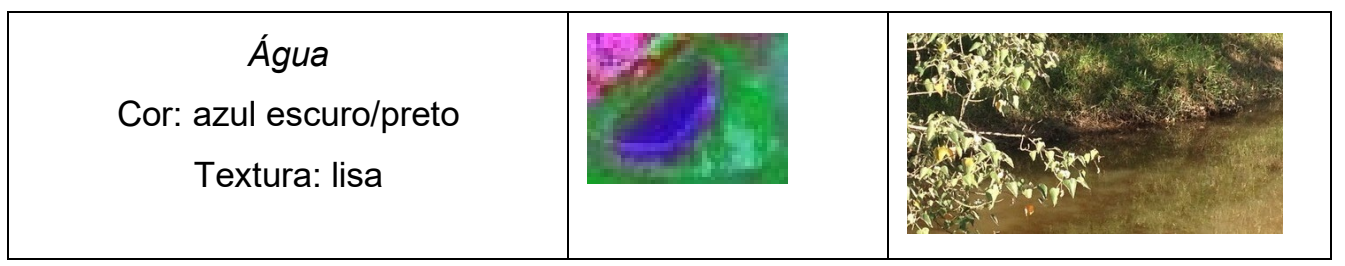

Fonte: Autora

Foi priorizada a classificação manual das imagens, em consonância com os trabalhos de campo realizados.

\subsubsection{Hidrologia}

Para a realização da análise morfométrica da drenagem, foram utilizados trabalhos de Christofoletti (1980) e Dibieso (2006). As metodologias propostas e aplicadas pelos referidos autores e usadas neste trabalho, para a análise morfométrica da Bacia Hidrográfica do Rio Buquira (Monteiro Lobato - SP), foram:

- $\quad$ Cálculo da área e perímetro da bacia;

- Hierarquização da rede hidrográfica;

- $\quad$ Densidade hidrológica;

- $\quad$ Densidade de drenagem;

- $\quad$ Coeficiente de manutenção.

Após a utilização das ferramentas de operações métricas do software ArcGis, concluiu-se que a Bacia possui $417 \mathrm{~km}^{2}$ de área e um perímetro de $140 \mathrm{~km}$. 
A hierarquização dos canais fluviais das sub-bacias foi feita pelo método de Strahler (1952, apud CHRISTOFOLETTI, 1980), que consiste em dar uma hierarquia de ordem aos "segmentos de canais" de uma determinada rede hidrográfica, em ordem crescente, a partir das nascentes (canais de $1^{\mathrm{a}}$ ordem). Numeram-se todos os canais de nascentes, de ordem 1; em seguida, em todas as junções de canais de ordem 1, numeram-se os de ordem 2, idem para 3, quando se juntarem dois segmentos de canais de ordem 2, e assim sucessivamente. E nenhum canal de ordem inferior altera a ordem superior. (Tabela 5)

Tabela 5: Número de segmentos de canais da Bacia Hidrográfica do Rio Buquira (Monteiro Lobato - SP) na escala de 1:200.000

\begin{tabular}{|c|c|c|c|c|}
\hline $1^{\mathrm{a}}$ ordem & $2^{\mathrm{a}}$ ordem & $3^{\mathrm{a}}$ ordem & $4^{\mathrm{a}}$ ordem & Total \\
\hline 59 & 32 & 16 & 14 & 121 \\
\hline
\end{tabular}

Fonte: Autora

A Bacia Hidrográfica do Rio Buquira foi classificada como de $4 .^{a}$ ordem, possuindo 59 canais de drenagem de $1 .^{a}$ ordem e o total de 121 segmentos de canais. A soma dos números de canais, de acordo com sua hierarquia fluvial, serve de subsídio para o cálculo da densidade hidrográfica

Elaborou-se a Carta de Hierarquia Fluvial da Bacia Hidrográfica (figura 32), afim da melhor visualização dos dados: 
Figura 32 - Carta de Hierarquia Fluvial da Bacia Hidrográfica do Rio Buquira (Monteiro Lobato - SP)

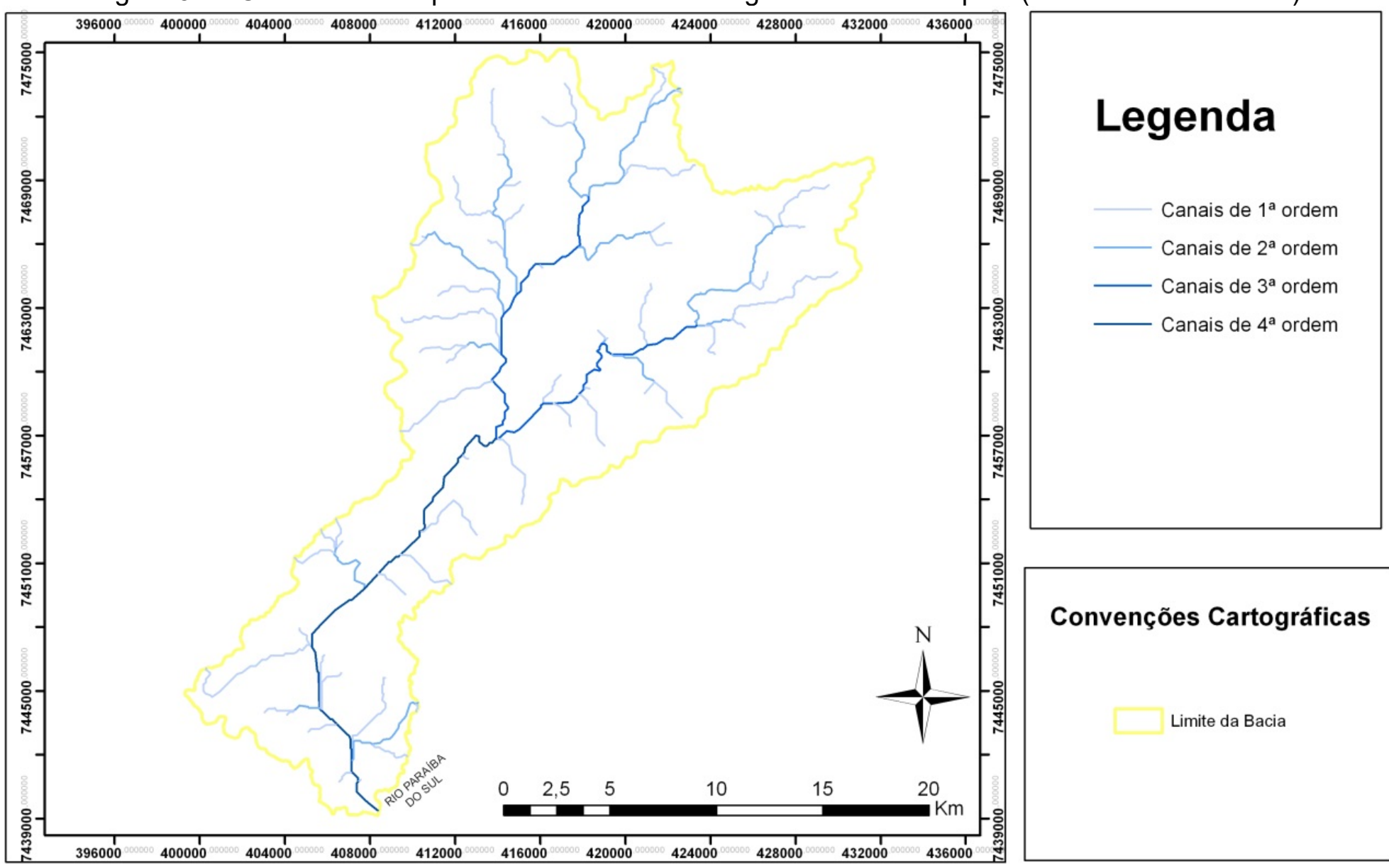

Carta de Hierarquia Fluvial da bacia hidrográfica do Rio

Sistema de Projeção Universal Transversa de Elaboração: Kátia Fernanda Pereira Mercator - UTM Dez/2016

$\underbrace{}_{\text {UNIERSIDADE DE }}$

@ CNPq Buquira 
A densidade hidrográfica refere-se ao número de rios por $\mathrm{km}^{2}$. Densidade hidrográfica: $\mathrm{Dh}=\mathrm{N} 1 / \mathrm{A}$, onde $\mathrm{N} 1$ é o número de canais de $1^{\mathrm{a}}$ ordem, $\mathrm{A}$ é a área da bacia considerada.

Densidade hidrográfica

$\mathrm{Dh}=\mathrm{n} 1 / \mathrm{A}$

$\mathrm{Dh}=59 / 417 \mathrm{~km}^{2}$

$\mathrm{Dh}=0,14\left(\right.$ rios por $\left.\mathrm{km}^{2}\right)$

A densidade hidrográfica compara a frequência ou a quantidade de cursos d'água (de $1^{\mathrm{a}}$ ordem), existente em uma área de tamanho padrão como o $\mathrm{km}^{2}$, oferecendo, juntamente com a densidade de drenagem, indicativos sobre o escoamento superficial da água e o desenvolvimento de processos erosivos.

Para a definição da densidade de drenagem, após o cálculo da área da bacia hidrográfica, calcula-se o comprimento de seus segmentos de canais. Os comprimentos dos segmentos de canais de cada ordem hierárquica estão descritos no Tabela 6:

Tabela 6: Comprimento dos segmentos de canais $(\mathrm{km})$ da Bacia Hidrográfica do Rio Buquira (Monteiro Lobato - SP)

\begin{tabular}{|c|c|c|c|c|}
\hline $1^{\mathrm{a}}$ ordem & $2^{\mathrm{a}}$ ordem & $3^{\mathrm{a}}$ ordem & $4^{\mathrm{a}}$ ordem & Total \\
\hline 118,93 & 56,07 & 28,02 & 23,77 & 226,81 \\
\hline
\end{tabular}

Fonte: Autora

A bacia hidrográfica do Rio Buquira (Monteiro Lobato - SP) possui, ao todo, 226,81 km de cursos d'água, sendo que 118,93 km são de $1^{\text {a }}$ ordem e 23,77 km, de 
$4^{\mathrm{a}}$ ordem. Além de oferecer subsídios para o cálculo da densidade de drenagem, o cálculo do comprimento dos canais, oferece subsídios para a análise da evolução da rede hidrográfica da bacia.

A densidade de drenagem compara o comprimento dos cursos d'água de uma área de tamanho padrão, como o $\mathrm{km}^{2}$. Densidade de drenagem: $\mathrm{Dd}=\mathrm{Lt} / \mathrm{A}$, onde $\mathrm{Lt}$ é o comprimento total de todos os canais da rede hidrográfica. A é a área da bacia. $\mathrm{O}$ resultado é dado em $\mathrm{Km} / \mathrm{km}^{2}$ (Tabela 7 )

Densidade de drenagem $\left(\mathrm{km} / \mathrm{km}^{2}\right)$

Exemplo ( $1^{\mathrm{a}}$ ordem)

$\mathrm{Dd}=\mathrm{Lt} / \mathrm{A}$

$\mathrm{Dd}=118,93 / 217 \mathrm{~km}^{2}$

$\mathrm{Dd}=0,54 \mathrm{~km} / \mathrm{km}^{2}$

Tabela 7: Densidade de drenagem da Bacia Hidrográfica do Rio Buquira (Monteiro Lobato $\mathrm{SP})\left(\mathrm{km} / \mathrm{km}^{2}\right)$

\begin{tabular}{|c|c|c|c|c|}
\hline $1^{\mathrm{a}}$ ordem & $2^{\mathrm{a}}$ ordem & $3^{\mathrm{a}}$ ordem & $4^{\mathrm{a}}$ ordem & Área Total \\
\hline 0,54 & 0,25 & 0,12 & 0,10 & 1,04 \\
\hline
\end{tabular}

Fonte: Autora

Quanto maior for a densidade de drenagem, mais rápido se dará o escoamento superficial em uma bacia hidrográfica. Além disso, ela serve também, como indicador sobre as características geomorfológicas de uma área, pois as maiores densidades de drenagem ocorrem em áreas com declividades mais acentuadas, e as menores densidades em áreas com declividades mais suaves. 
O coeficiente de manutenção fornece uma estimativa da área mínima necessária para a manutenção de um metro de canal de escoamento permanente. $\mathrm{O}$ índice é calculado através da densidade de drenagem. Coeficiente de manutenção: $C m=(1 / D d) \times 1000\left(m^{2}\right)$, onde Dd é a Densidade de drenagem. O resultado é dado em $\mathrm{m}^{2} / \mathrm{m}$ (tabela 8 )

Coeficiente de manutenção $\left(\mathrm{m}^{2} / \mathrm{m}\right)$

$$
\begin{aligned}
& \text { Exemplo }\left(1 .^{a} \text { ordem }\right) \\
& \mathrm{Cm}=(1 / \mathrm{Dd}) \times 1000\left(\mathrm{~m}^{2}\right) \\
& \mathrm{Cm}=(1 / 0,54) \times 1000 \\
& \mathrm{Cm}=2777,77
\end{aligned}
$$

Tabela 8: Coeficiente de manutenção da Bacia Hidrográfica do Rio Buquira (Monteiro Lobato - SP) $\left(\mathrm{m}^{2} / \mathrm{m}\right)$

\begin{tabular}{|c|c|c|c|c|}
\hline $1^{\mathrm{a}}$ ordem & $2^{\mathrm{a}}$ ordem & $3^{\mathrm{a}}$ ordem & $4^{\mathrm{a}}$ ordem & Área Total \\
\hline 1851,85 & 4000 & 8333,33 & 10000 & 961,53 \\
\hline
\end{tabular}

Fonte: Autora

Deve-se salientar que são as características geológicas, geomorfológicas, pedológicas e de uso e de ocupação dessas áreas as principais responsáveis pela manutenção desses canais de escoamento. Assim, com a alteração destas condições, muda-se também a capacidade de armazenamento da água pluvial, ou seja, com a impermeabilização do solo, por exemplo, a área mínima necessária para manter um metro de canal de escoamento (principalmente nos períodos de menor precipitação), não é mais a mesma daquela de uma área que mantém as suas características originais de permeabilidade. 


\subsubsection{Breve análise da qualidade da água}

Foram analisadas a qualidade da água em três pontos próximos à foz, ao médio curso e à nascente, utilizando a análise à campo com o Ecokit (figura 33) - um conjunto de reagentes desenvolvido para controle da qualidade da água e educação ambiental.

Figura 33: Pontos de coleta de amostras para análise da água

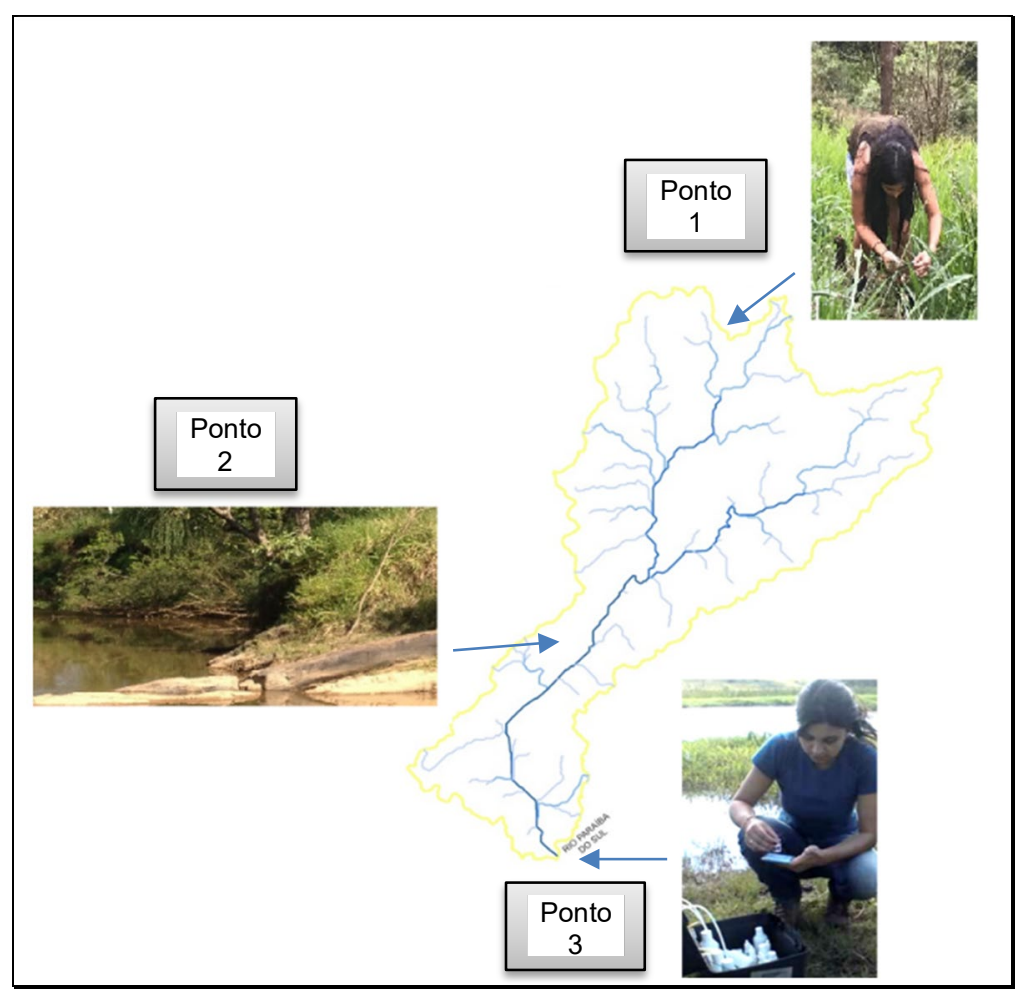

Fonte: Trabalho de campo ( Rio Buquira)

As análises buscariam avaliar o nível de potabilidade da água, utilizando a resolução CONAMA n³57/2005 e portarias do Ministério da Saúde como parâmetros para avaliar as seguintes variáveis: Ferro, PH, Turbidez, Amônia, Oxigênio Dissolvido e Cloro. 
Tabela 9: Análise da Potabilidade da água com as variáveis Ferro, $\mathrm{pH}$, Turbidez, Amônia, Oxigênio Dissolvido e Cloro

\begin{tabular}{c|c|c|c|c|c|c} 
& \multicolumn{5}{|c}{ Amônia, Oxigênio Dissolvido e Cloro } \\
& Ferro & PH & Turbidez & Amônia & $\begin{array}{c}\text { Oxigênio } \\
\text { Dissolvido }\end{array}$ & Cloro \\
\hline Foz & $\begin{array}{c}0,25 \\
\mathrm{mgFL}\end{array}$ & 6 & $50 \mathrm{NTU}$ & $0,25 \mathrm{mgNL}$ & $7 \mathrm{mg} / \mathrm{L}$ & $\begin{array}{c}0,1 \\
\mathrm{mgCl} / \mathrm{L}\end{array}$ \\
\hline $\begin{array}{c}\text { Médio } \\
\text { Curso }\end{array}$ & $0,25 \mathrm{mgFL}$ & 6 & $50 \mathrm{NTU}$ & $0,25 \mathrm{mgNL}$ & $7 \mathrm{mg} / \mathrm{L}$ & $\begin{array}{c}0,1 \\
\mathrm{mgCl} / \mathrm{L}\end{array}$ \\
\hline & & & & & & $<0,1$ \\
Nascente & $<25 \mathrm{mgFL}$ & 6,5 & $<50 \mathrm{NTU}$ & $0,1 \mathrm{mgNL}$ & $7 \mathrm{mg} / \mathrm{L}$ & $\mathrm{mgCl} / \mathrm{L}$
\end{tabular}

Fonte: Autora

Onde, no geral:

- O ferro encontrou-se dentro dos padrões, segundo a resolução Conama 357/05 que tem o limiar de 0,3 mgFL como valor aceitável;

- O pH foi considerado um valor positivo, principalmente nas áreas de nascente;

- A turbidez foi considerada aceitável, sendo que o Ministério da Saúde considera até 100 NTU como valor considerável para consumo;

- A amônia encontrada destacou-se em níveis médios, pois considera-se que acima de 0,01 mgNL já é um valor representativo para determinadas espécies de peixes;

- O oxigênio dissolvido apresentou um valor na média, pois concentrações abaixo de $5 \mathrm{mg} / \mathrm{L}$ podem não matar alguns organismos presentes na água, mas aumenta a susceptibilidade ao estresse; (EMBRAPA, 2001) 
- O cloro foi considerado bom para a potabilidade da água, onde foram encontrados valores maiores na foz e no médio curso devido ao maior tratamento da água.

Por fim, concluímos que a potabilidade da água foi considerada satisfatória.

Em comparação aos anos iniciais de nossa pesquisa, Nordeman e Danelon (1990) atentam aos valores do PH da água na área da bacia no ano de 1990:

\begin{abstract}
$\mathrm{pH}$ - As águas de chuva estão ácidas e esta acidez pode ser explicada em grande parte pelo excesso observado de ânions (decorrente principalmente do excesso de sulfato e nitrato) em relação aos cátions, e talvez também pela injeção de ácidos orgânicos na atmosfera provenientes da Mata Atlântica. Como consequência desta acidez temos observado que as águas do rio apresentam valores de $\mathrm{pH}$ de até 5.7 no período chuvoso contra um valor normal de 6.7 em período seco. As nascentes, única fonte de abastecimento da região, estão igualmente apresentando fortes sinais de acidificação na época das chuvas.
\end{abstract}

Onde a pesquisa aponta valores de $\mathrm{pH}$ de 5.7 em período chuvoso e valores de 6.7 no período seco, cujas nascentes apresentavam fortes sinais de acidificação nas épocas chuvosas.

Atualmente, a CETESB não possui um ponto de monitoramento na Bacia, sendo este sugerido no Plano de Bacias, no Rio Buquira, na confluência do córrego do Bengala, em São José dos Campos. 


\section{CAPÍTULO IV}

$\underline{\text { Resultados }}$ 


\subsection{Contexto histórico em pequena e grande escala: as mudanças ocorridas na Bacia do Rio Buquira}

São José dos Campos, que fora estância climatérica até 1977, pela Lei n. 1566/70 (Código Administrativo da cidade), enfatizava a questão do desperdício de recursos hídricos, em seu Capítulo IV, "Do controle da água e do sistema de eliminação de dejetos": "Art. 68: Em caso de calamidade pública no abastecimento de água potável por falta da mesma, todos os usuários deverão restringir ao máximo o consumo de água, evitando assim, o agravamento da situação". ${ }^{52}$

E o mesmo código ressaltou, em seu Art. 76:

Compete ao Departamento de Água e Esgoto da Prefeitura da Estância de São José dos Campos, verificar as condições de lançamentos de esgotos sanitários e resíduos industriais, tratados ou não nas bacias hidrográficas de São José dos Campos comunicandose os órgãos competentes para as providências cabíveis, necessárias à preservação da salubridade dos receptores. A autorização para lançamento de esgotos e resíduos industriais em cursos d’água, será feita pela autoridade sanitária competente..$^{53}$

Por outro lado, existia a preocupação na preservação dos leitos dos rios, como é afirmado no Art. 311:

É proibida a extração de areia em todos os cursos de água do Município, quando:

I - o local receber contribuição de esgotos;

II - modifiquem o leito ou as margens do curso de água;

III - possibilitem a formação de locais que causarem, por qualquer forma, a estagnação de águas;

\footnotetext{
$52<$ https://leismunicipais.com.br/a2/sp/s/sao-jose-dos-campos/lei-ordinaria/1970/157/1566/leiordinaria-n-1566-1970-institui-o-codigo-administrativo-da-estancia-de-sao-jose-dos-campos-daoutras-providencias?q=1566>. Acesso em: 15 ago. 2017.

53 <https://leismunicipais.com.br/a2/sp/s/sao-jose-dos-campos/lei-ordinaria/1970/157/1566/leiordinaria-n-1566-1970-institui-o-codigo-administrativo-da-estancia-de-sao-jose-dos-campos-daoutras-providencias?q=1566>. Acesso em: 15 ago. 2017.
} 
IV - de algum modo, possa oferecer perigo a pontes, muralhas ou qualquer obra construída nas margens ou sobre os leitos dos rios. ${ }^{54}$

E a cidade estava ainda em transição de uma "estância" para "industrializada", se considerarmos o Art. 299 do referido Código: "Fica proibida a formação de pastagens na zona urbana do Município." ${ }^{55}$ Portanto, elementos tipicamente rurais deveriam ser retirados em uma cidade em franca urbanização.

A ocupação dos "vazios urbanos" intensificaram-se em São José dos Campos a partir dos anos 70 do século passado, pois a cidade passava por um boom em seu processo de industrialização. ${ }^{56}$ Segundo Reani (2013), "os loteamentos invadem as APPs, ${ }^{57}$ desviam os cursos d'água e causam erosão e o assoreamento de córregos", ${ }^{58}$ sendo que São José dos Campos era onde o "meio ambiente e o social têm se perdido em meio aos interesses econômicos". ${ }^{59}$

Segundo Reani, "faltaram políticas públicas mais eficazes quanto à ocupação dos vazios urbanos, à fiscalização dos loteamentos clandestinos, à ocupação de áreas

\footnotetext{
54 <https://leismunicipais.com.br/a2/sp/s/sao-jose-dos-campos/lei-ordinaria/1970/157/1566/leiordinaria-n-1566-1970-institui-o-codigo-administrativo-da-estancia-de-sao-jose-dos-campos-daoutras-providencias?q=1566>. Acesso em: 15 ago. 2017.

55 <https://leismunicipais.com.br/a2/sp/s/sao-jose-dos-campos/lei-ordinaria/1970/157/1566/leiordinaria-n-1566-1970-institui-o-codigo-administrativo-da-estancia-de-sao-jose-dos-campos-daoutras-providencias?q=1566>. Acesso em: 25 06. 2018.

${ }^{56}$ Cf. PEREIRA, Cristiano José. A cidade, a fábrica e a juventude: a mão-de-obra juvenil na Fábrica de Louças "Santo Eugênio e o contexto industrial de São José dos Campos-SP (1921-1973). 2009. Dissertação de Mestrado. Faculdade de Filosofia Letras e Ciências Humanas da Universidade de São Paulo, Departamento de História.

57 "Legalmente, as áreas de preservação permanente foram criadas no Brasil pela Lei $n^{\circ} .4 .771$ que instituiu o novo Código Florestal, promulgada pelo Presidente (...) Castello Branco , em 16 de setembro de 1965 (...)" In: RIBEIRO, Glaucus Vinicius Biasetto. "A origem histórica do conceito de Área de Proteção Permanente no Brasil". In: Revista Thema. $<$ http://www.terrabrasilis.org.br/ecotecadigital/pdf/origem-historica-do-conceito-de-area-depreservacao-permanente-no-brasil.pdf>. Acesso em: 12 jan. 2014.

${ }^{58}$ REANI, Regina Tortorella. Organização do espaço e políticas públicas ambientais no município de São José dos Campos-SP. 2013. Tese de Doutorado. Faculdade de Filosofia, Letras e Ciências Humanas da Universidade de São Paulo, Departamento de Geografia, p. 200.

${ }^{59}$ REANI, Regina Tortorella. Organização do espaço e políticas públicas ambientais no município de São José dos Campos-SP. 2013. Tese de Doutorado. Faculdade de Filosofia, Letras e Ciências Humanas da Universidade de São Paulo, Departamento de Geografia, p. 264.
} 
com declividade superior a $30 \%$ e à ocupação das áreas de proteção e preservação ambiental, em especial do Banhado". ${ }^{60}$

Posteriormente, Reani assinala:

$\mathrm{Na}$ década de 1990, o eixo da Rodovia Dutra continua sendo a principal área de atração de novas indústrias; tem a instalação da Tectelcom (Tecsat, 1997), a Century (1998), a Johnson Controls (1998) e a Solectron (1999), que seguem a orientação prevista no zoneamento urbano de 1990. Na década de 2000, tem-se uma diminuição na instalação de indústrias de grande porte no município e o aumento no número de indústrias de médio e pequeno porte ${ }^{61}$

O espraiamento urbano de São José dos Campos, também levava em consideração a Zona Leste, processo esse que passou por uma ruptura considerável entre 1970 e 1980, pois houve desapropriações para a criação da Refinaria Henrique Lage em perímetro urbano, em terrenos então ocupados por bairros incipientes:

A instalação da REVAP foi realizada em desacordo com a legislação vigente, pois a área onde ela se instala estava prevista como área de expansão urbana, sendo que a maior parte da área de expansão estava prevista como área residencial (...) a REVAP se instala em uma área onde já havia aprovação para loteamento (...). ${ }^{62}$

A especulação de terrenos tornou-se cada vez maior em São José dos Campos, e áreas não tão distantes do centro de São José dos Campos, as quais poderiam ser servidas pelo transporte urbano, passaram a ser valorizadas para

\footnotetext{
${ }^{60}$ REANI, Regina Tortorella. Organização do espaço e políticas públicas ambientais no município de São José dos Campos-SP. 2013. Tese de Doutorado. Faculdade de Filosofia, Letras e Ciências Humanas da Universidade de São Paulo, Departamento de Geografia, p. 261.

${ }^{61}$ REANI, Regina Tortorella. Organização do espaço e políticas públicas ambientais no município de São José dos Campos-SP. 2013. Tese de Doutorado. Faculdade de Filosofia, Letras e Ciências Humanas da Universidade de São Paulo, Departamento de Geografia, p. 218.

${ }^{62}$ REANI, Regina Tortorella. Organização do espaço e políticas públicas ambientais no município de São José dos Campos-SP. 2013. Tese de Doutorado. Faculdade de Filosofia, Letras e Ciências Humanas da Universidade de São Paulo, Departamento de Geografia, p. 216.
} 
moradia. Isto aconteceu em vários bairros da Zona Norte de São José dos Campos, tais como o Mirante do Buquirinha.

Neste trabalho, dentre outros aspectos, elaboramos mapas ao longo de séries temporais por nós definidas a priori: 1985, 1995, 2005 e 2015. Estas séries procuram dar conta do final do século XX e começo do século XXI. Os principais efeitos de uma ocupação humana desmensurada são mais facilmente percebidos quando os dados de satélite são compilados em séries temporais espaçadas, tais como em décadas. Dessa forma, o estudo através de mapas revela contrastes visíveis, de tal forma que foi possível verificar elementos de ocupação humana que afetaram de forma construtiva e destrutiva a bacia do rio Buquira nas cidades de São José dos Campos e Monteiro Lobato.

A análise dos mapas contribui para um avanço da ciência geográfica, na medida em que são documentos após a sua elaboração com parâmetros científicos. Os mapas servem como ponto de partida para uma maior conscientização para a tomada de decisões por parte de várias instituições que devem, cada vez mais, aperfeiçoar a preservação das bacias hidrográficas.

Realizamos em nossa pesquisa um estudo pormenorizado sobre a bacia do rio Buquira, que se encontra, em sua maior parte, na cidade de Monteiro Lobato. A foz do rio Buquira encontra-se na cidade vizinha, São José dos Campos, polo de desenvolvimento regional no Vale do Paraíba. Esta cidade cresceu desordenadamente após a década de 60 do século passado, trazendo ocupação humana para o interior da bacia do Buquira. Utilizamos como exemplo para entendermos aspectos dessa ocupação humana o bairro Mirante do Buquirinha, cujas ruas encontram-se muito próximas a uma região de várzea do rio Buquira. As vias de acesso ao bairro são a SP-50 (Rodovia "Monteiro Lobato") e a Estrada dos Freitas, 
denominada posteriormente "Estrada Municipal José Benedito de Oliveira". O bairro ainda é existente e está em processo de legalização por parte da Prefeitura Municipal de São José dos Campos.

Em anos anteriores, os alagamentos do rio Buquira provocaram muitos transtornos aos moradores de São José dos Campos e Monteiro Lobato:

\begin{abstract}
Estradas rurais abandonadas [-] A precariedade das estradas rurais bastante castigadas pelas chuvas e as muitas reclamações dos agricultores de São José dos Campos que, em vista dessa situação, vêm encontrado dificuldades para escoar suas produções (...) // Ressalta o vereador [joseense, Antônio Escada, PMDB] que uma das piores dificuldades enfrentadas pelos produtores rurais é a falta de condições das estradas vicinais (...) no caso de São José dos Campos, e cita algumas que precisam urgentemente serem asfaltadas: Bonsucesso, São Francisco Xavier, Vargem Grande e a do bairro dos Freitas. ${ }^{63}$
\end{abstract}

Outra reportagem realizada pelo jornal O Valeparaibano assinalava:

Abastecimento de água requer maior controle $[-] \mathrm{A}$ falta de suporte técnico e a inexistência de financiamentos oficiais são apontados, com freqüência, como causas do caos ambiental no Estado [de São Paulo]. São precárias as condições de funcionamento dos sistemas de abastecimento de água, a ausência de tratamento de esgotos e as distorções na disposição final da já deteriorada qualidade de vida da população. $(. . .)^{64}$

Em 1985 o Brasil vivia o final da ditadura militar. A censura havia sido oficialmente reprimida nos meios de comunicação. Havia uma maior liberdade de expressão no Brasil. Neste ano Tancredo Neves foi eleito de forma indireta no Congresso Nacional, derrotando o ex-governador de São Paulo, Paulo Maluf. A morte

\footnotetext{
${ }^{63}$ O VALEPARAIBANO. "Estradas rurais abandonadas", 14.02.1985, p. 3.

${ }^{64}$ O VALEPARAIBANO; MESTRIEL, Reinaldo. "Abastecimento de água requer maior controle", 22.02.1985, p. 12.
} 
de Tancredo Neves, em 21 de abril, fez com que a presidência do Brasil ficasse com José Sarney, um dos governadores do Maranhão na época da ditadura. ${ }^{65}$

Dez anos depois, a região Norte de São José dos Campos sofria com as constantes chuvas e alagamentos:

Chuva castiga o Vale [-] A falta de prevenção e conhecimento dos eventos naturais, mais uma vez deixou o Vale do Paraíba em situação de calamidade com as chuvas que caíram nas últimas horas. [Em São José dos Campos] a zona norte da cidade foi a mais atingida, onde 20 famílias foram forçadas a abandonar suas residências. O rio Buquira, que margeia a SP-50, está muito acima do seu leito e invadiu casas e pontos de várias fazendas. ${ }^{66}$

O bairro Mirante do Buquirinha já aparecia como local onde os alagamentos grassavam:

Buquirinha recebe alerta sobre doenças [-] Um trabalho de orientação de moradores residentes em áreas atingidas pelas enchentes começou a ser desenvolvido ontem pela Prefeitura. Uma equipe, com membros de três secretarias, foi até o bairro do Mirante do Buquirinha alertando sobre as doenças causadas pelas chuvas. Durante toda a tarde de ontem, os funcionários permaneceram no local dando instruções aos moradores. O bairro, com cerca de 80 casas, a maioria construída nas encostas de um morro, faz parte do rol dos loteamentos clandestinos da cidade e, segundo a Prefeitura, os moradores, que correm o risco de perder suas residências, se recusam a sair do local. ${ }^{67}$

Cinco dias depois, a Prefeitura ressaltava que "os moradores" já haviam deixado as casas: "(...) Segundo a Assessoria de Imprensa da Prefeitura, no Mirante do Buquirinha os moradores já haviam deixado as casas, retirando inclusive móveis e

\footnotetext{
${ }^{65}$ Cf. FAUSTO, Boris. História do Brasil. 12. ed. São Paulo: EDUSP, 2006, p. 512-519.

${ }^{66}$ O VALEPARAIBANO. "Chuva castiga o Vale", 07.02.1995, capa.

${ }^{67}$ O VALEPARAIBANO. "Buquirinha recebe alerta sobre doenças", 10.02.1995, capa.
} 
demais pertences, quando houve a inundação". ${ }^{68} \mathrm{~A}$ inundação não atingiu todo o bairro; muitos moradores permaneceram, mesmo com riscos.

Em 1995, o Brasil vivia o início de uma recuperação econômica, após o preparo e posterior implantação no Plano Real, no governo de Itamar Franco. No ano anterior, Fernando Henrique Cardoso, foi o candidato eleito nas eleições pelo PSDB. ${ }^{69}$

Em 2005, a Prefeitura de São José dos Campos alegava que o bairro era composto de sub-habitações, mas com a denominação de "favela", como veremos na reportagem abaixo, publicada no jornal "O Valeparaibano" em janeiro de 2005:

Rios transbordam e alagam moradias e pontos em S. José [-] CHEIA - Na zona norte, no Mirante do Buquirinha, os moradores observavam com medo o aumento do nível do rio. Segundo eles, o alagamento no início do ano já se tornou "tradicional". // Segundo a dona-de-casa Maria Aparecida Conceição, 58 anos, a rua 6 - que fica paralela ao rio, na parte mais baixa do bairro - tem sofrido alagamentos desde sábado. // Em áreas mais baixas, entre Monteiro Lobato e São José, o rio transbordou, inundando pastagens e plantações. Em alguns pontos era impossível ver a margem do Rio Buquirinha, [sic] devido à formação de lagos com até 100 metros de largura. // A Defesa Civil vistoriou os locais ontem e informou que está monitorando as áreas de risco. A prefeitura informou que as áreas invadidas fazem parte do plano de desfavelização, que deve estar concluído em quatro anos. ${ }^{70}$

Em trabalhos de campo realizados entre 2016 e 2019, verificamos que apenas parte da Rua 6 encontra-se em região de várzea. Boa parte da rua faz parte de uma elevação maior, com riscos consideravelmente menores de inundações. Muitas moradias do bairro Mirante do Buquirinha são construída sem materiais nobres de

\footnotetext{
68 O VALEPARAIBANO. "Bairros da Zona Norte são os mais afetados", 15.02.1995, p. 5.

${ }^{69}$ Cf. FAUSTO, Boris. História do Brasil. 12. ed. São Paulo: EDUSP, 2006, p. 576.

70 O VALEPARAIBANO; GARCIA, Edmon. "Rios transbordam e alagam moradias e pontos em S. José", 27.01.2005, p. 3.
} 
acabamento, mas não a ponto da Prefeitura Municipal de São José dos Campos realizar, no governo de Eduardo Cury, ${ }^{71}$ uma pretensa "desfavelização".

Nesse processo de "desfavelização", a Defesa Civil local "monitorava" casas próximas a rios e encostas:

S. José monitora 500 casas à beira de rios e em encostas [-] Em São José dos Campos, a Defesa Civil monitora quatro bairros com riscos de deslizamentos de terra e alagamentos - Mirante do Buquirinha, Buquirinha 1, Buquirinha 2 e Rio Comprido (...) // A maior preocupação é com o solo encharcado por causa da chuva insistente dos últimos dias. Também a cheia do rio Buquira está sendo monitorada para que não cause transtornos à população. // Ontem, o nível do rio já começava a dar sinais de transbordamento, chegando muito perto da casa do pedreiro Eromar Alves Andrade, 39 anos, que mora no Bairro Mirante do Buquirinha, com a mulher e os três filhos. // "Muitas vezes, para sair de casa, a gente tem que enfrentar a água até o joelho mesmo. Os meninos até brincam de barco aqui", disse Andrade. (... $)^{72}$

Em 2005, o Brasil era governado por Luís Inácio “Lula” da Silva, eleito em grande vitória após perder quatro eleições pelo PT (Partido dos Trabalhadores). Programas como o "Fome Zero" e o "Bolsa Família" acabaram por deslocar, para o plano nacional, a análise dos problemas brasileiros do econômico para o social, influenciando decisivamente setores da sociedade brasileira. ${ }^{73}$

Posteriormente, em 2009, o governo municipal joseense realizou desapropriações no Mirante do Buquirinha:

Prefeitura adere ao programa de apoio às vítimas de enchente [-] $\mathrm{O}$ Prefeito de São José dos Campos encaminhou à Câmara Municipal nesta quinta-feira (4) um projeto de lei solicitando autorização para

\footnotetext{
${ }^{71}$ Atualmente cumpre seu segundo mandato como Deputado Federal.

72 O VALEPARAIBANO. "S. José monitora 500 casas à beira de rios e em encostas", 28.01.2005, p. 7.

${ }^{73}$ EXAME (periódico); CAPUTO, Victor. “O que fica para o Brasil após 13 anos de governo do PT”. Disponível em: <https://exame.abril.com.br/brasil/o-que-fica-para-o-brasil-apos-13-anos-de-governo-do-pt/>. Acesso em: 20 jul. 2017.
} 
assinatura de convênio com o Governo do Estado visando a inclusão do município no Programa "Novo Começo". // A iniciativa prevê pagamento de auxílio moradia emergencial no valor de $R \$ 300,00$ e uma parcela de $R \$ 1$ mil para as famílias que se encontrarem em situação de vulnerabilidade causada pelas enchentes, além da inclusão nos programas habitacionais executados em parceria entre o Estado e o município. // Em 2009, a Secretaria de Habitação propôs a desapropriação para recuperação ambiental de 51 casas no Mirante do Buquirinha (região norte) que foram construídas em loteamento clandestino, em área de várzea, e que sofriam recorrentes alagamentos. Das 51 famílias, 36 já saíram do bairro e os imóveis foram demolidos e o restante ou já fechou acordo com a Prefeitura, ou está em negociação. O valor disponível para desapropriação é de $\mathrm{R} \$$ 2,87 milhões. $^{74}$

O que a Prefeitura de São José dos Campos denominou, em 2009, como "recuperação ambiental", nada mais foi do que a demolição de casas e abandono dos terrenos às condições do tempo. Ainda hoje, no bairro, é possível encontrar tampas de bueiro na região da várzea do Rio Buquira. Tivemos a ocasião de verificar pessoalmente o vazamento de esgoto a menos de 50 metros da calha do rio.

Em 2015, o Brasil tinha como presidente Dilma Rousseff, em seu segundo mandato e, após passar por processo de impeachment em 31 de agosto de 2016, o poder ficou nas mãos do vice-presidente, Michel Temer.

Em contexto local, outro alagamento do Mirante do Buquirinha em 2016, provocou por parte da Prefeitura de São José dos Campos, com o então prefeito Carlinhos Almeida, o cadastro dos atingidos pela enchente em programas habitacionais do município:

PREFEITURA DE SÃO JOSÉ DOS CAMPOS [-] Tendo em vista o ocorrido nos últimos dias no Bairro Mirante do Buquirinha, onde diversas moradias foram alagadas e moradores foram obrigados a sair de casa pela enchente; // Considerando o disposto no Decreto

\footnotetext{
${ }^{74}$ PREFEITURA DE SÃO JOSÉ DOS CAMPOS. "Prefeitura adere ao programa de apoio às vítimas de enchente", 04.03.2010. Disponível em: <http://servicos2.sjc.sp.gov.br/noticias/noticia.aspx?noticia_id=6982>. Acesso em: 9 set. 2016.
} 
Municipal 16.736, que disciplina os critérios de priorização aos atendimentos de munícipes que se encontrem nesta situação; $A$ Prefeitura Municipal de São José dos Campos COMUNICA aos moradores desta comunidade que: Todos que desejarem sair das residências onde moram, que tenham laudo da Defesa Civil em conformidade com as exigências legais (Portaria 412, de 06 de agosto de 2015 do Ministério das Cidades), e preencham as demais condições exigidas no Programa Minha Casa Minha Vida, terão até o próximo dia 19 de fevereiro, inclusive, para fazer sua manifestação na Secretaria Municipal de Habitação, na Rua José de Alencar, 123, Vila Santa Luzia, São José dos Campos. Os telefones são o 3947-8482 e o 3947-8160. // A cota destinada a esta finalidade localiza-se nos residências Bom Retiro II, Cajurú I e Cajurú III. O número de unidades disponíveis para este segmento fica limitado ao previsto no Decreto Municipal 16.717, de 13 de novembro de 2015. São José dos Campos, 11 de fevereiro de 2016.

O deslocamento então proposto pela Prefeitura aos que desejassem deixar suas casas na região das enchentes do rio Buquira era de sair da Zona Norte para a Zona Leste, em uma distância de aproximadamente 30 quilômetros, retirando, dessa forma, os moradores de sua região, e, portanto de suas raízes.

Mesmo com as enchentes e desejo do Poder Público municipal de retirar os munícipes do Mirante do Buquirinha, houve resistência constante destes. A Prefeitura, em outubro de 2017, deu início à regularização do bairro, realizando um "mutirão de coleta de documentos". ${ }^{75}$ Portanto, a Prefeitura tentou acabar e/ou diminuir a extensão do bairro Mirante do Buquirinha, mas foi derrotada por organizações de ocupação humana, pois estas acabam tendo influência decisiva em âmbito municipal. Ocupações reprimidas geram eleitores descontentes; provavelmente o Mirante do Buquirinha será considerado legalmente um bairro no próximo ano de 2020 , ano de eleições municipais. Para um bairro que já foi colocado em um plano de desfavelização, é um ganho realmente notável.

\footnotetext{
${ }^{75}$ PREFEITURA DE SÃO JOSÉ DOS CAMPOS. "Mutirão no Mirante do Buquirinha vai recolher documentação de imóveis", 09.10.2017. Disponível em:

<http://servicos2.sjc.sp.gov.br/noticias/noticia.aspx?noticia_id=28114>. Acesso em: 11 jul. 2018.
} 
4.2 Cartas de uso e cobertura da terra para os anos de 1985, 1995, 2005 e 2015

Serão apresentados os resultados referentes às análises do uso e cobertura da terra para os anos de 1985, 1995, 2005 e 2015, ilustrando a situação de cada ano com os mapas temáticos, dados e tabelas.

Posteriormente, serão esboçados os mapas indicativos do módulo Land Chang Modeler (LCM), com as informações sobre as mudanças ocorridas nos anos de referência. Será realizada uma comparação entre os mapas de 1985/1995, de 1995/2005, de 2005/2015, em uma série histórica de 10 anos; e por fim será apresentado uma comparação de 30 anos entre 1985 e 2015. 


\subsubsection{Uso e cobertura da terra em 1985}

Com base nas imagens de satélite foi possível observar que em 1985 o principal uso da terra era a floresta primária, que ocupava uma área de 16525,7 hectares de terra. Em segundo lugar estavam as pastagens com 11147,9 hectares. Em terceiro lugar estavam a vegetação secundária com 10956,1 hectares, em quarto lugar estava a classe solo exposto com 1169,3 hectares, seguida pelo reflorestamento com 914,4 hectares. Em sexto lugar estava a classe água, ocupando 615,5 hectares, seguida pela classe urbano em sétimo lugar com 634,7 hectares.

As categorias e as respectivas áreas podem ser observadas a seguir (tabela 10):

Tabela 10: Uso e cobertura da terra em 1985

\begin{tabular}{cc}
\hline CLASSE & ÁREA \\
\hline ÁREA CONSTRUÍDA & 384,3 \\
PASTAGEM & 11147,9 \\
SOLO EXPOSTO & 1169,3 \\
REFLORESTAMENTO & 914,4 \\
FLORESTA PRIMÁRIA & 16525,7 \\
VEGETAÇÃO & 10956,1 \\
SECUNDÁRIA & \\
ÁGUA & 634,7 \\
\hline \multicolumn{2}{c}{ Fonte: Autora }
\end{tabular}

No ano de 1995, o principal uso da terra ainda era a floresta primária, onde após este período, houve uma maior exploração da vegetação nativa de forma 
predatória para fins econômicos, suprimindo as árvores de maior valor lucrativo e, principalmente para o estabelecimento de outro uso da terra.

A categoria pastagem, que apresentou expressiva dimensão, preconiza que a criação de gado foi uma das atividades mais lucrativas no momento, em detrimento das plantações de café, que não apresentaram produtividade suficiente no período.

Considerando a vegetação secundária, esta substituiu a vegetação nativa existente, dando lugar a vegetação de transição, formada por arbustos, gramíneas e pequenas árvores.

As áreas urbanas e áreas construídas cresciam na região norte de São José dos Campos, em razão ao êxodo rural de habitantes de Minas Gerais e Paraná, que encontraram nesta área uma identidade com o local. Tanto que, atualmente, esta zona apresenta elementos muito característicos do meio rural.

A categoria agricultura não foi passível de classificação, tanto nas imagens Landsat, quanto na representatividade real da área, pois poucas culturas despontaram na região, sendo concentradas, sobretudo, em pequenas propriedades.

Temos a espacialização do uso e cobertura na bacia, representada na figura 34. 
Figura 34 - Carta de uso e cobertura da terra para o ano de 1985

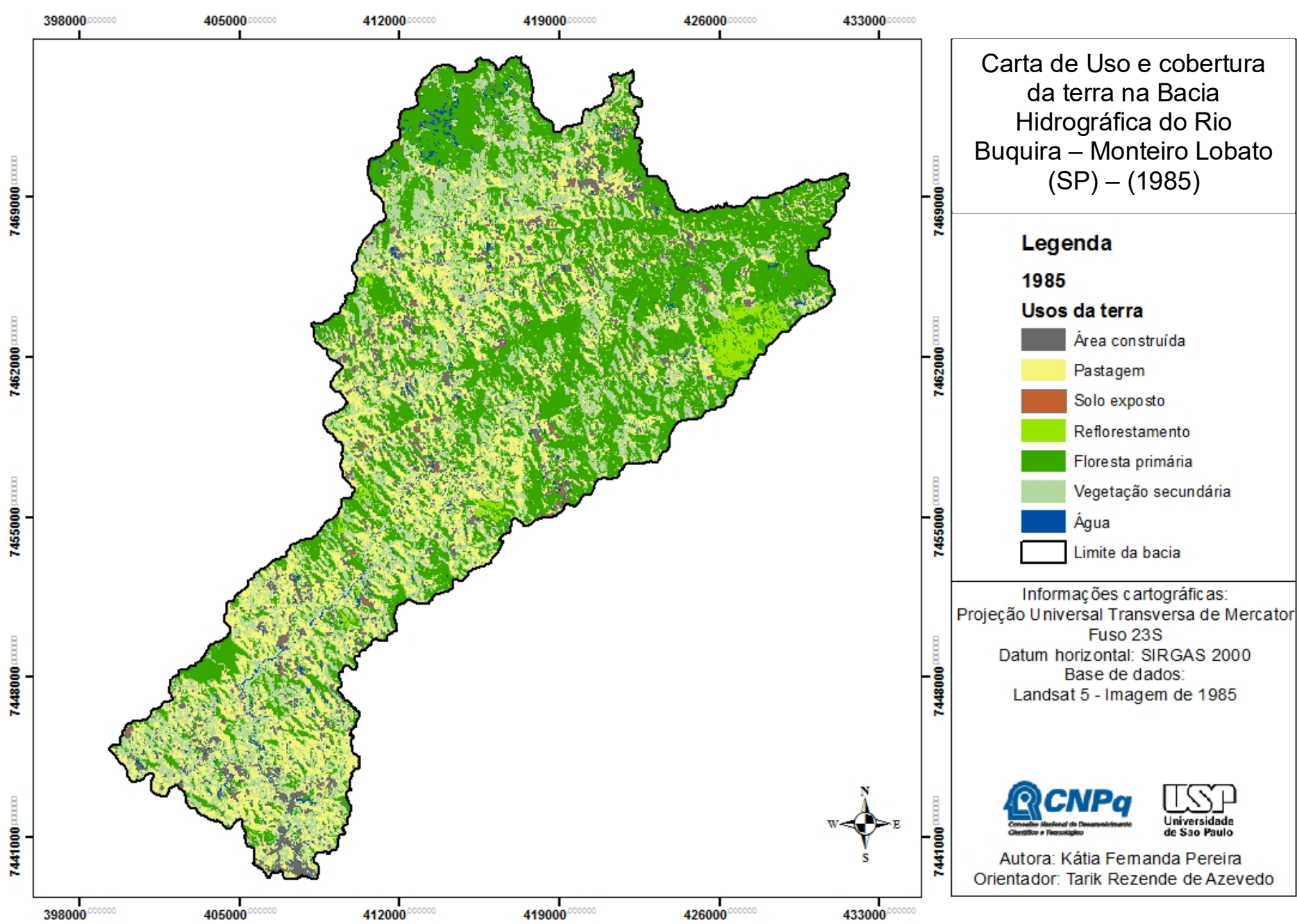

Fonte: Autora 


\subsubsection{Uso e cobertura da terra em 1995}

Neste ano, a classe área construída contou com 1633,0 hectares, pastagem com 10804,7699 hectares, solo exposto com 617,7 hectares, reflorestamento com 1964,0699 hectares, floresta primária com 17827,1 hectares, vegetação secundária com 8885,1640 hectares e água com 254,7 hectares, como observamos na tabela 11 :

Tabela 11 : Uso e cobertura da terra em 1995

\begin{tabular}{ll}
\hline CLASSE & ÁREA \\
\hline ÁREA CONSTRUÍDA & 1633,0 \\
PASTAGEM & 10804,7 \\
SOLO EXPOSTO & 617,7 \\
REFLORESTAMENTO & 1964,0 \\
FLORESTA PRIMÁRIA & 17827,1 \\
VEGETAÇÃO & 8885,1 \\
SECUNDÁRIA & \\
ÁGUA & 254,7 \\
\hline
\end{tabular}

Fonte: Autora

Constata-se que passados 10 anos, a categoria floresta primária continuou sendo a mais presente, com $53 \%$ da área total, e o considerável aumento deve-se a questão da categoria vegetação secundária ter diminuído. Ou seja, o campestre deixou de ser vegetação de transição.

Em pastagem houve um decréscimo, sobretudo, para criação de áreas construídas. Estradas foram ampliadas, habitações expandiram-se e, deram lugar inúmeros loteamentos irregulares, principalmente das margens à foz do Rio Buquira. Afinal, São José dos Campos despontara-se como grande polo tecnológico, a verticalidade tomara conta da cidade, e nem todos possuíam acesso à moradia. A especulação imobiliária crescia ao mesmo ritmo da ascensão da grande cidade. 
O solo exposto deu lugar a algumas pequenas plantações de milho, algodão, feijão, mandioca, café e laranja e, de acordo com a localização no mapa, à granjas e habitações, e também, à queimadas.

Conferimos na figura 35, a carta de uso e cobertura na área da bacia para o ano de 1995. 
Figura 35 - Carta de uso e cobertura da terra para o ano de 1995

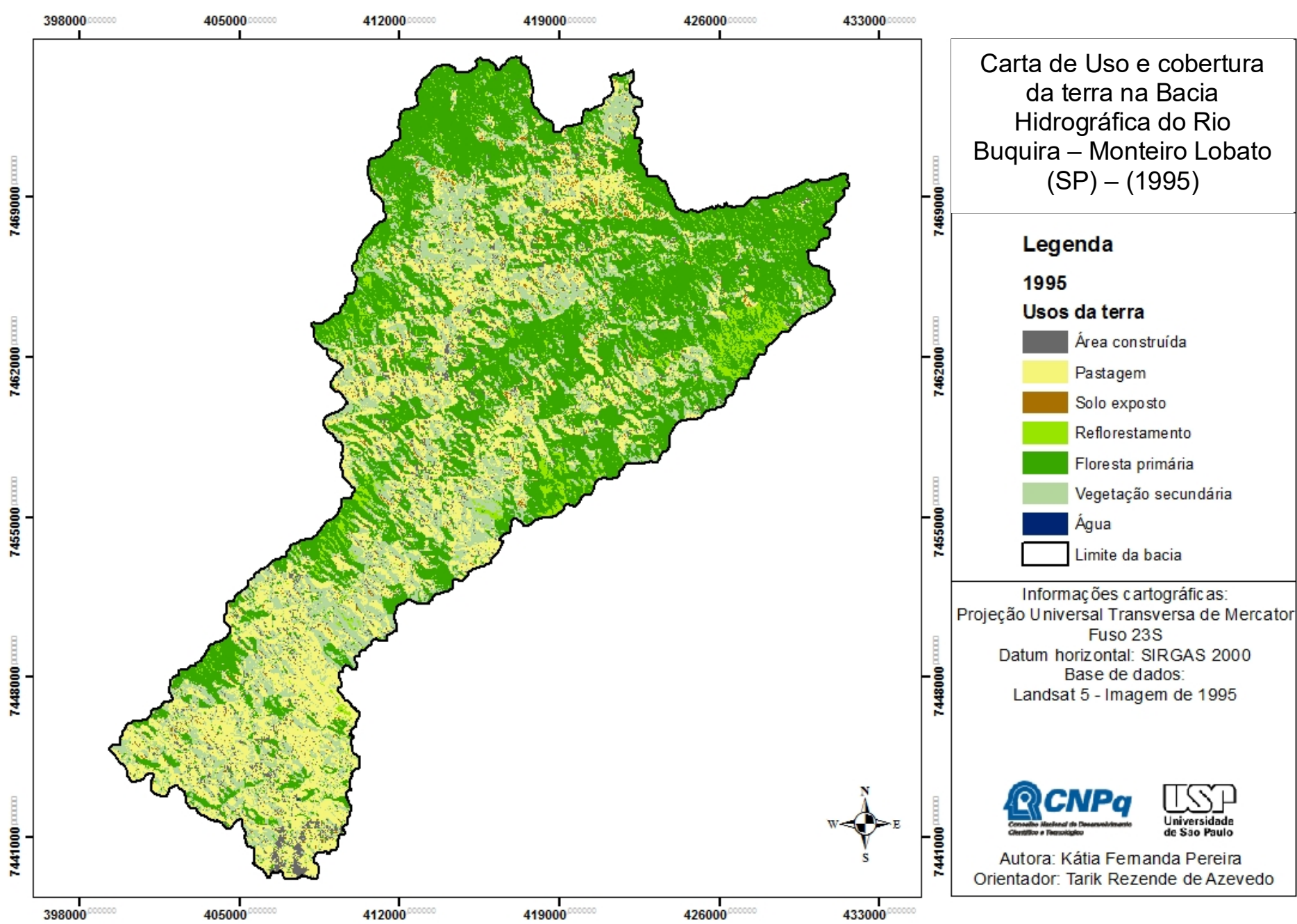

Fonte: Autora 


\subsubsection{Uso e cobertura da terra em 2005}

Para o ano de 2005, a tabela seguinte (tabela 12) mostra que a área construída diminuiu para 838,53 hectares, o que é reflexo das políticas públicas e de zoneamento da área em questão. Para as áreas de alagamento natural do rio, ou seja, 30 metros a partir da margem, deveriam ser desapropriadas as habitações aí existentes, tendo em vista o risco iminente das cheias do Rio Buquira. Inúmeras habitações foram expropriadas das áreas de risco, devido, à recorrentes casos de deslizamentos na Bacia.

Tabela 12: Uso e cobertura da terra em 2005

\begin{tabular}{ll}
\hline CLASSE & ÁREA \\
\hline ÁREA CONSTRUÍDA & 838,5 \\
PASTAGEM & 10160,9 \\
SOLO EXPOSTO & 1423,8 \\
REFLORESTAMENTO & 1089,4 \\
FLORESTA PRIMÁRIA & 16190,5 \\
VEGETAÇÃO SECUNDÁRIA & 10478,7 \\
ÁGUA & 1550,7 \\
\hline
\end{tabular}

Fonte: Autora

A categoria pastagem continuou diminuindo neste ano, com 10160,9 hectares, mas ainda demonstrando que a criação de gado ainda era expressiva. O solo exposto voltou a apresentar aumento, com 1423,8 hectares, devido à novos usos da terra, e às áreas preparadas para o plantio.

O reflorestamento, com 1089,4 hectares foi uma categoria que se desenvolveu devido à crescente exploração de pinus e eucaliptos e junto às diretrizes 
de recomposição de matas ciliares, por mais que, contraditoriamente, ocupassem áreas distantes dos cursos d'águas.

Com a significativa prevalência da floresta primária (16190,5 hectares) e vegetação secundária (10478,7 hectares), a constatação foi de que a área da bacia mantinha-se preservada, ao contrário de outras áreas diversas que se tornaram predatórias e não recompuseram sua vegetação natural. Ademais, o turismo neste dado momento já avançava em direção à Serra da Mantiqueira (norte da bacia). Desta forma, estas áreas conservadas da bacia hidrográfica seriam atrativos para o turismo ecológico, principalmente no município de Monteiro Lobato.

A categoria água foi a que apresentou pequena sazonalidade entre os anos; ou devido a precipitações, ou pela mata ciliar recobrir a visão ao espectro eletromagnético, ou por diversas modificações nas calhas dos rios, provenientes das canalizações, inerentes não só na área urbana.

Observamos na figura 36, a carta de uso e cobertura na área da bacia para o ano de 2005: 
Figura 36 - Carta de uso e cobertura da terra para o ano de 2005

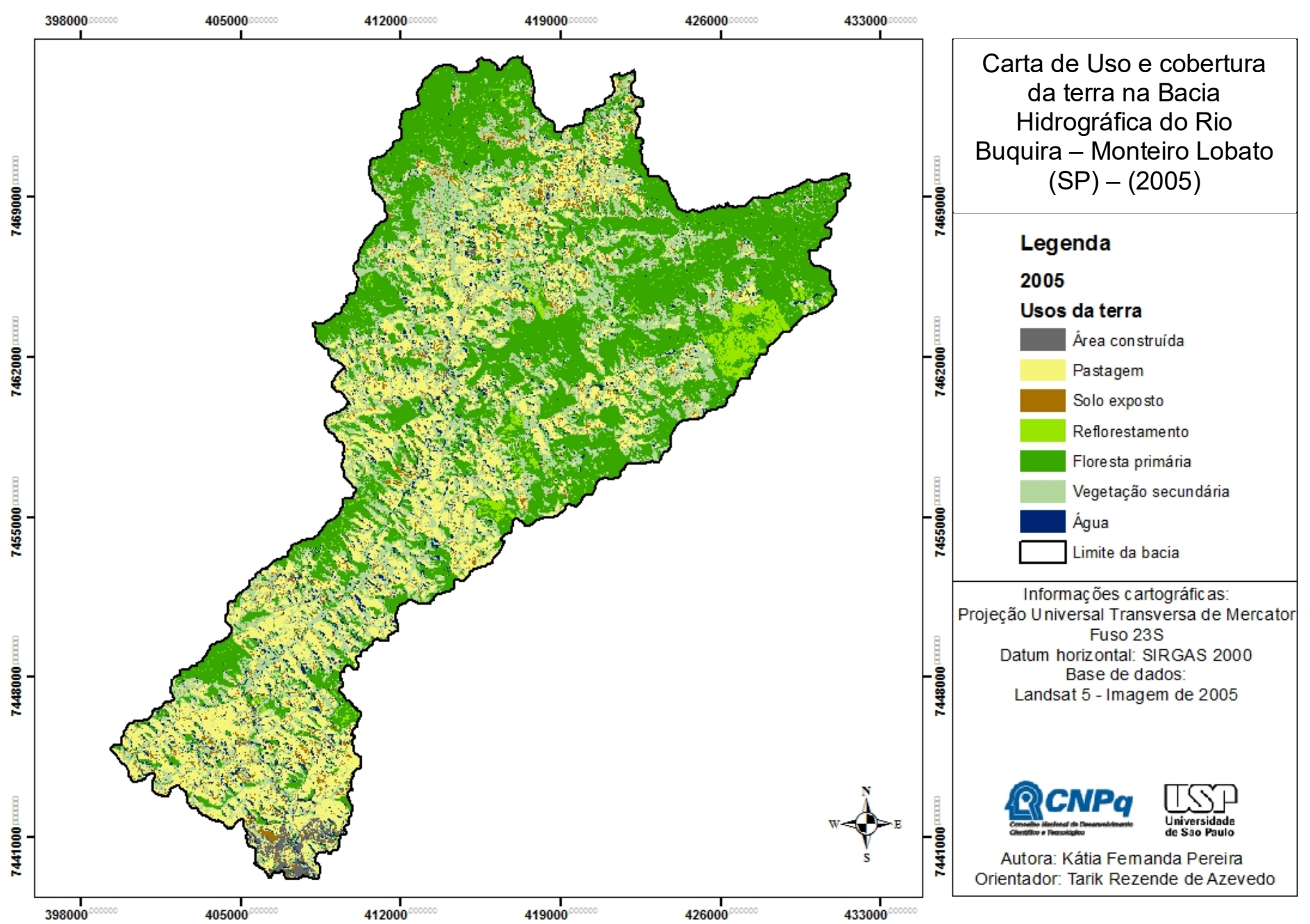

Fonte: Autora 


\subsubsection{Uso e cobertura da terra em 2015}

Neste ano, as categorias de uso e cobertura da terra, possuíam as seguintes dimensões: área construída com 1069,4 hectares, pastagem com 6895,1 hectares, solo exposto com 112,5 hectares, reflorestamento com 186,3 hectares, floresta primária com 16913,4 hectares, vegetação secundária com 14331,2 hectares e água com 545,5 hectares, como vemos na tabela 13 :

Tabela 13: Uso e cobertura da terra em 2015

\begin{tabular}{ll}
\hline CLASSE & ÁREA \\
\hline ÁREA CONSTRUÍDA & 1069,4 \\
PASTAGEM & 6895,1 \\
SOLO EXPOSTO & 112,5 \\
REFLORESTAMENTO & 1865,3 \\
FLORESTA PRIMÁRIA & 16913,4 \\
VEGETAÇÃO SECUNDÁRIA & 14331,2 \\
ÁGUA & 545,5 \\
\hline
\end{tabular}

Fonte: Autora

A tendência de desconcentração de áreas construídas na área da bacia, neste ano de 2015 , foi devido à ampliação de áreas residenciais na cidade de São José dos Campos e a facilidade à população com incentivos como Programas Minha Casa Minha Vida. Com implementos em áreas de São José dos Campos - antes desvalorizadas - como a região Leste, houve, de fato, a descentralização de moradias seguindo a nova dinâmica imobiliária. Somando-se a esta questão, constantemente cresceu-se a procura por lugares bucólicos para se viver, dando chance a locais mais ao norte da bacia. Contudo, somando-se o total da área construída, houve um aumento comparando-se ao ano anterior. 
Por fim, considera-se que as mudanças ocorridas nas outras categorias foram equilibradas dando destaques para as menores áreas de solo exposto, e para as maiores áreas de floresta primária. Damos atenção às áreas de água, como citamos anteriormente, as quais apresentaram pequenas alterações de classificação, devido à qualidade dos pixels das imagens de satélite, e por vezes, apresentarem ocorrência de maior pluviosidade.

A seguir (figura 37), observamos, a carta de uso e cobertura na área da bacia para o ano de 2015. 
Figura 37 - Carta de uso e cobertura da terra para o ano de 2015

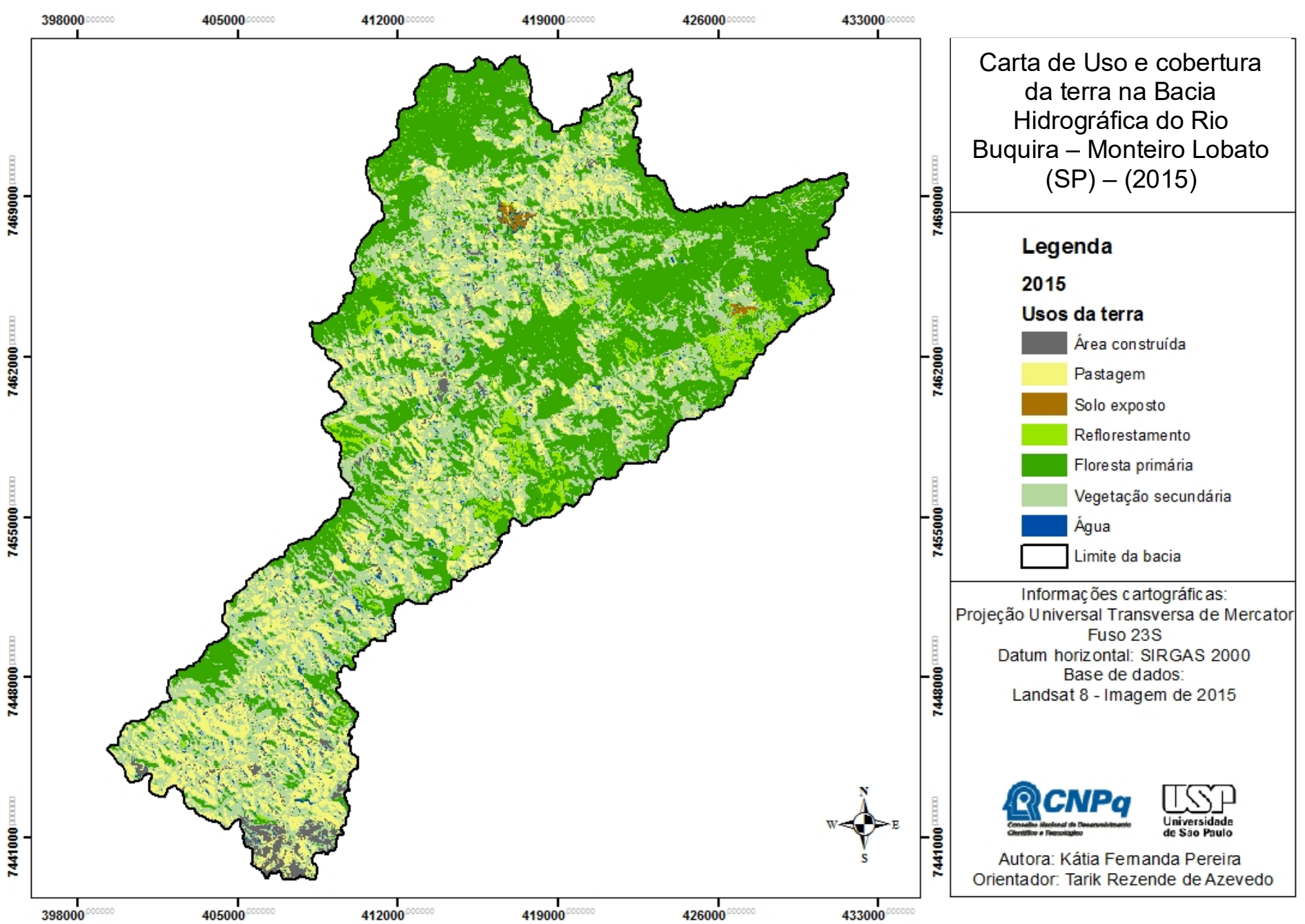

Fonte: Autora 


\subsection{Análise dos ganhos e perdas no uso da terra (por categoria)}

A partir das cartas de uso e cobertura da terra, foi possível detectar, agrupar e espacializar as alterações ocorridas. Esta análise é essencial para entendermos a dinâmica em curso no período estudado. espacial

Espacializamos as mudanças nas categorias com a apresentação dos mapas de Ganhos e perdas do uso da terra, cuja cor coral representa as áreas antes constituídas por uma categoria e que foram substituídas por outras categorias e a cor azul ilustra a área que era ocupada por uma categoria e passou a ser ocupada pela categoria atual.

No gráfico, trazemos a informação sobre a área (em hectares), onde as barras de cor roxa indicam as categorias que ganharam ou perderam área. Os valores negativos demonstram que a categoria selecionada perdeu área e os valores com sinal positivo evidenciam que a categoria selecionada ganhou área.

Esta análise possibilitou uma melhor compreensão das pressões ambientais e antropogênicas nas áreas naturais da bacia. Tendo em vista que a dinâmica transformação nos ambientes ocorre através das interrelações entre os aspectos biológicos, sociais, culturais e econômicos, a análise de ganho e perda no uso da terra na área da bacia hidrográfica do Rio Buquira mostrou-se de grande importância.

\subsubsection{Ganhos e Perdas da terra para a categoria Área construída}


A classe área construída foi adotada para caracterizar as áreas estruturadas por edificações e sistema viário, totalizando as áreas artificiais não agrícolas (IBGE, 2013) e somando-se as áreas artificiais agrícolas.

A grande concentração urbana encontra-se na porção sul da bacia, especificamente na zona norte de São José dos Campos (bairros como Vila Cândida, Alto da Ponte, Mirante do Buquira, Buquirinha, Freitas, dentre outros) e no município de Monteiro Lobato.

Entre 1985 e 1995 esta categoria apresentou ganhos, principalmente, sobre as categorias vegetação secundária e pastagem e apresentou apenas uma pequena perda para a área de reflorestamento, como podemos observar no seguinte gráfico (gráfico 3):

Gráfico 3: Ganhos e perdas de terra na categoria Área construída (1985-1995)

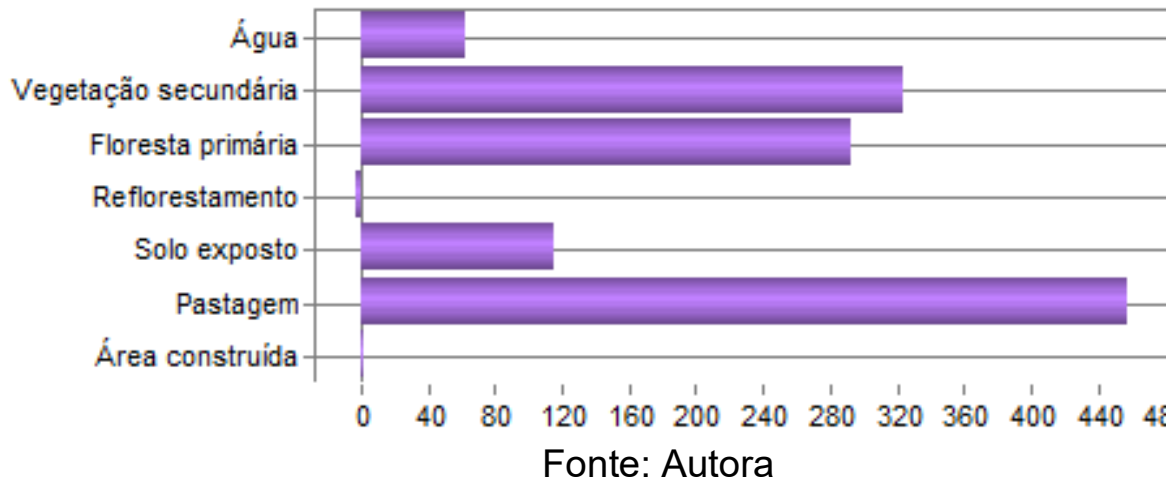

As alterações ocorridas nesse período estão registradas na figura 38, a qual espacializa as áreas onde ocorreram perda e ganho relacionadas à categoria. 
Figura 38: Mapa de ganho e perda na categoria Área construída. (1985-1995)

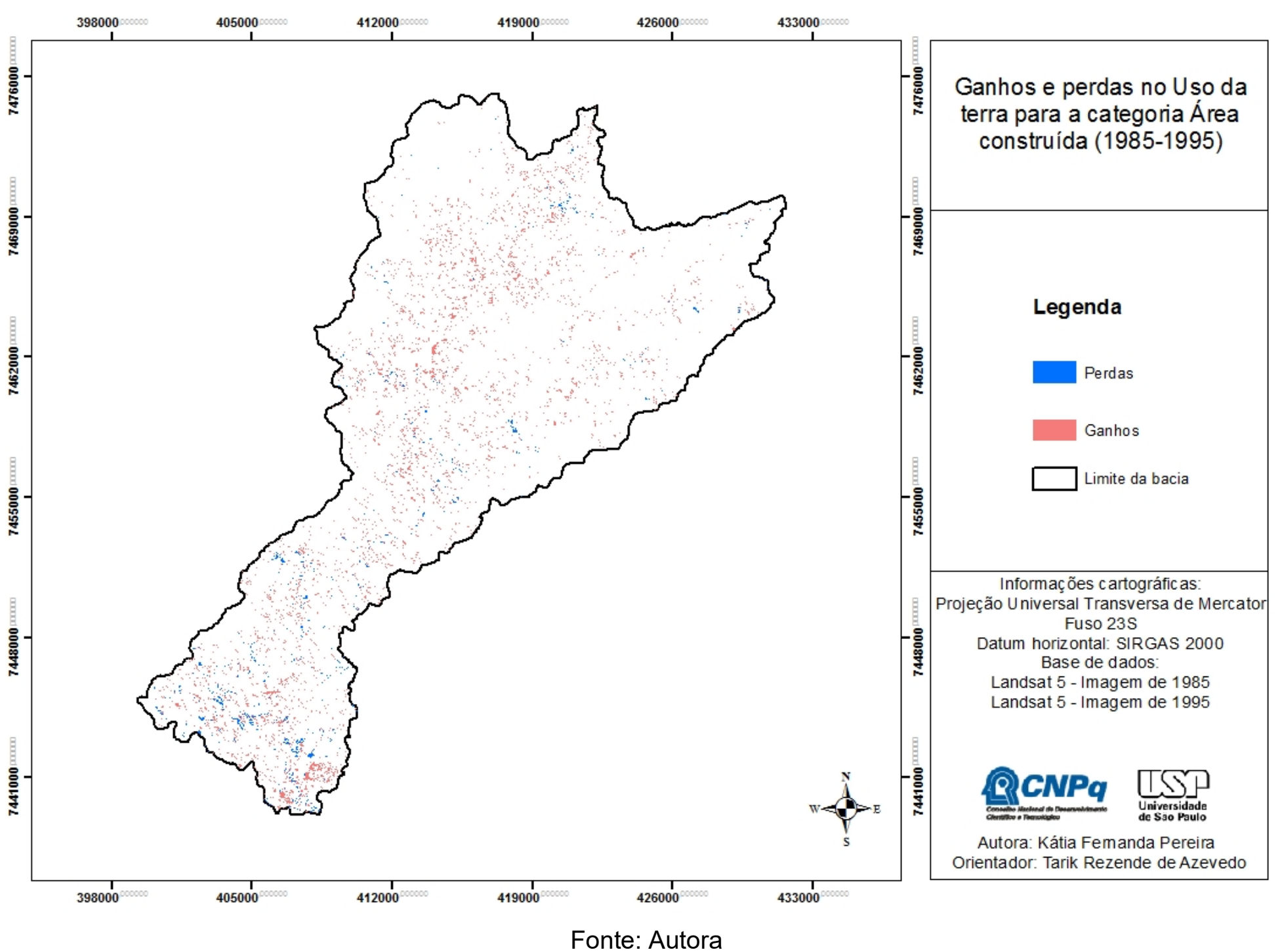


Entre 1995 e 2005, observamos que a categoria substituiu pequena área na categoria reflorestamento, e deu lugar a outras categorias como vegetação secundária e pastagem. Esta redução da área construída dentro destes anos, deve-se, principalmente a desapropriação de habitações irregulares, priorizando o Plano Diretor e o Zoneamento de São José dos Campos.

Gráfico 4: Ganhos e perdas de terra na categoria Área construída (1995-2005)

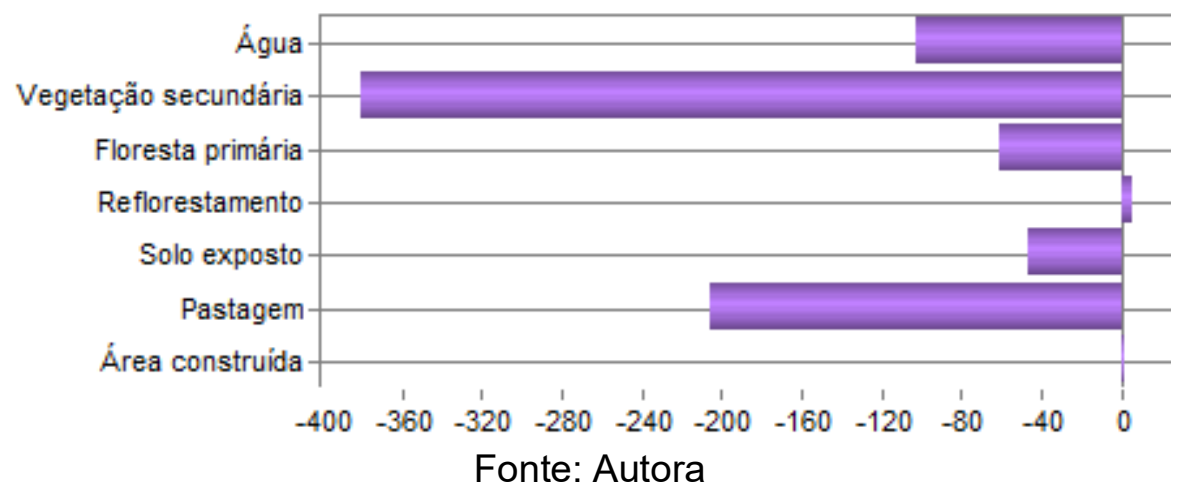

Espacializamos as perdas e ganhos da terra, na figura a seguir (figura 39): 
Figura 39: Mapa de ganho e perda na categoria Área construída. (1995-2005)

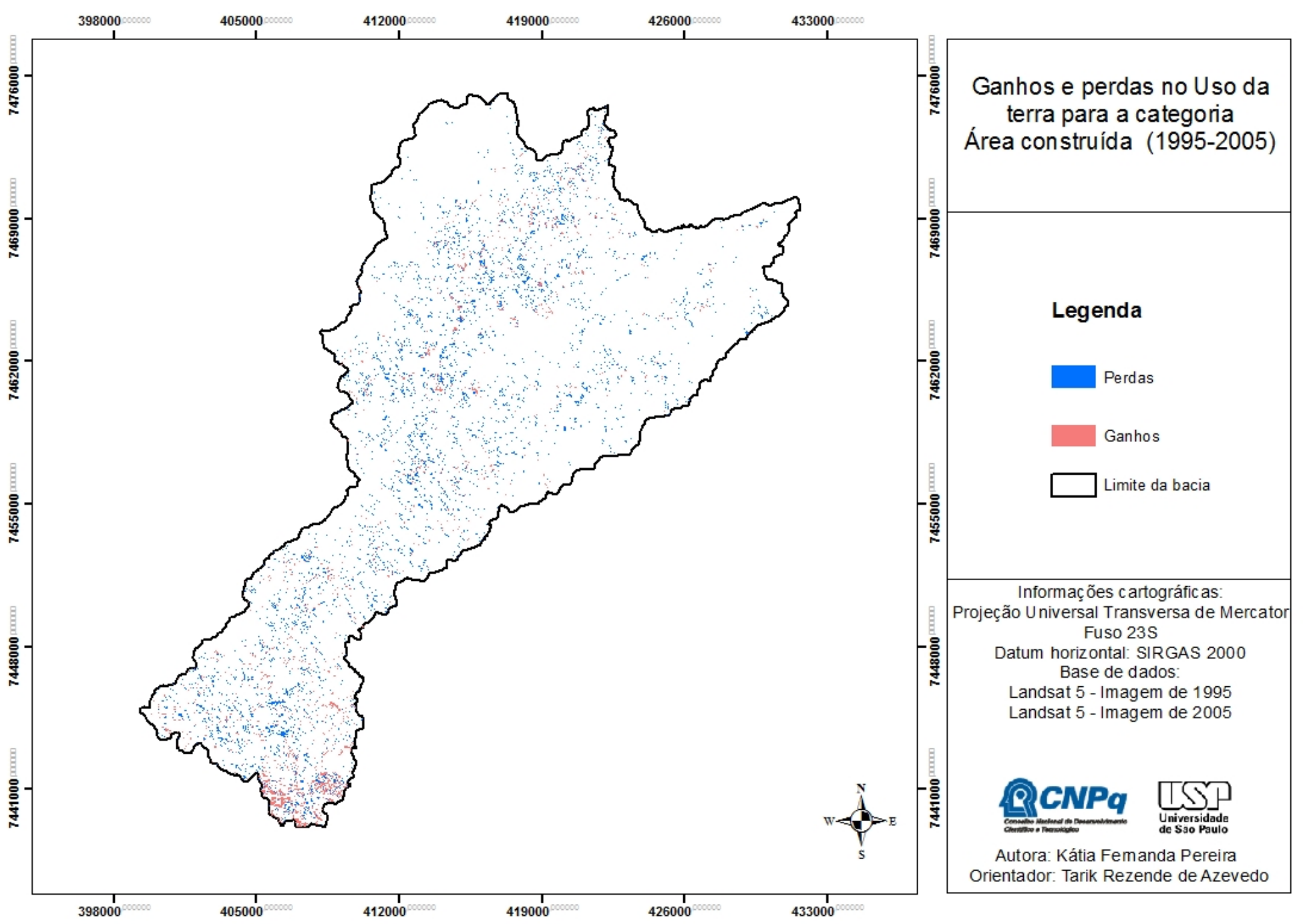

Fonte: Autora 
Para os anos entre 2005 e 2015 (gráfico 5), concluímos que as perdas na categoria deram lugar, essencialmente, à vegetação secundária e floresta primária, obtendo um ganho nas categorias, principalmente, de solo exposto e pastagem.

A desconcentração de áreas irregulares trouxe a presença de pontos isolados de vazios urbanos.

Gráfico 5: Ganhos e perdas de terra na categoria Área construída (2005-2015)

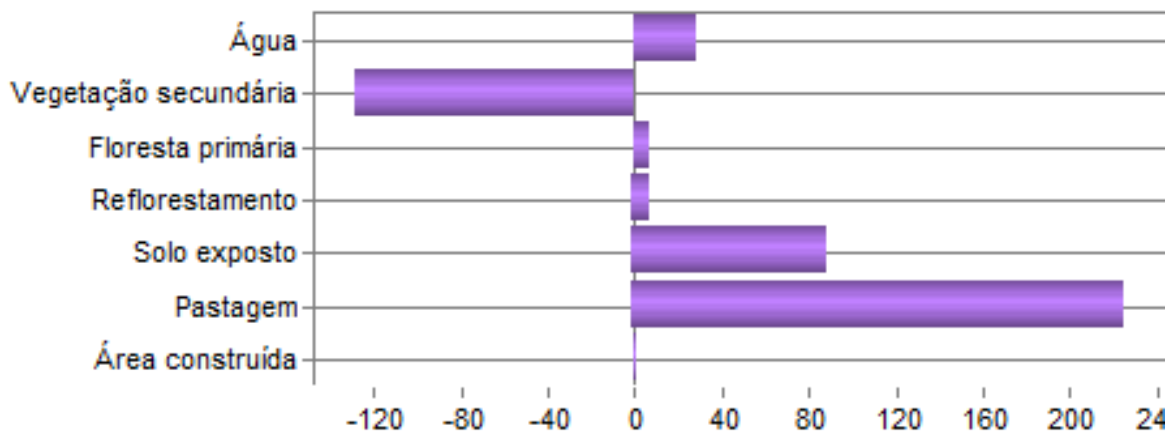

Fonte: Autora

As transformações ocorridas nesse período estão registradas na figura 40 , a qual espacializa as áreas onde ocorreram perda e ganho relacionadas à categoria, e a seguir, o quadro 1 apresenta a comparação dos mapas de ganho e perda para a categoria: 
Figura 40: Mapa de ganho e perda na categoria Área construída (2005-2015)

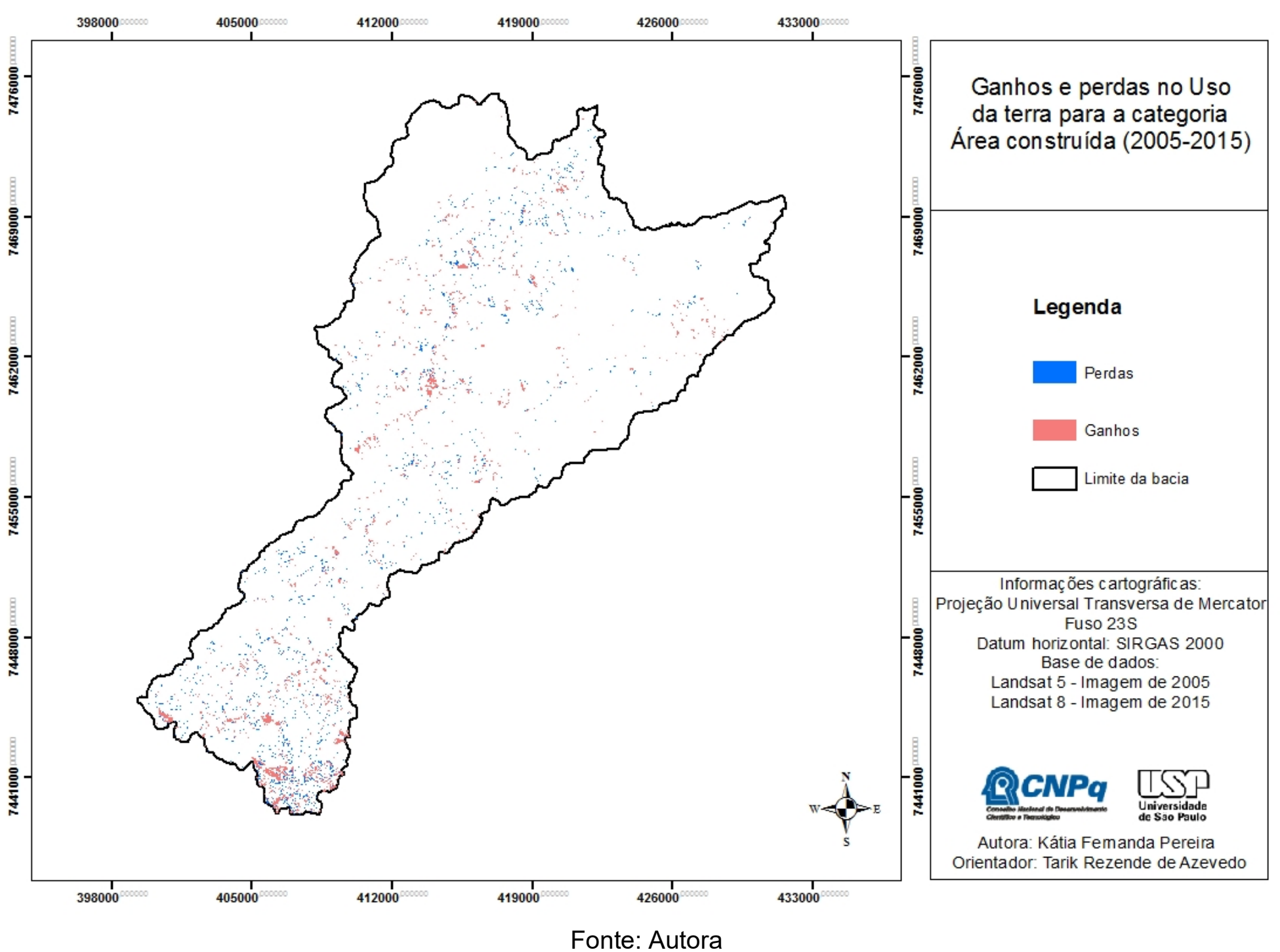


Quadro 1: Comparação dos mapas de ganhos e perdas na área da bacia para a categoria Área construída

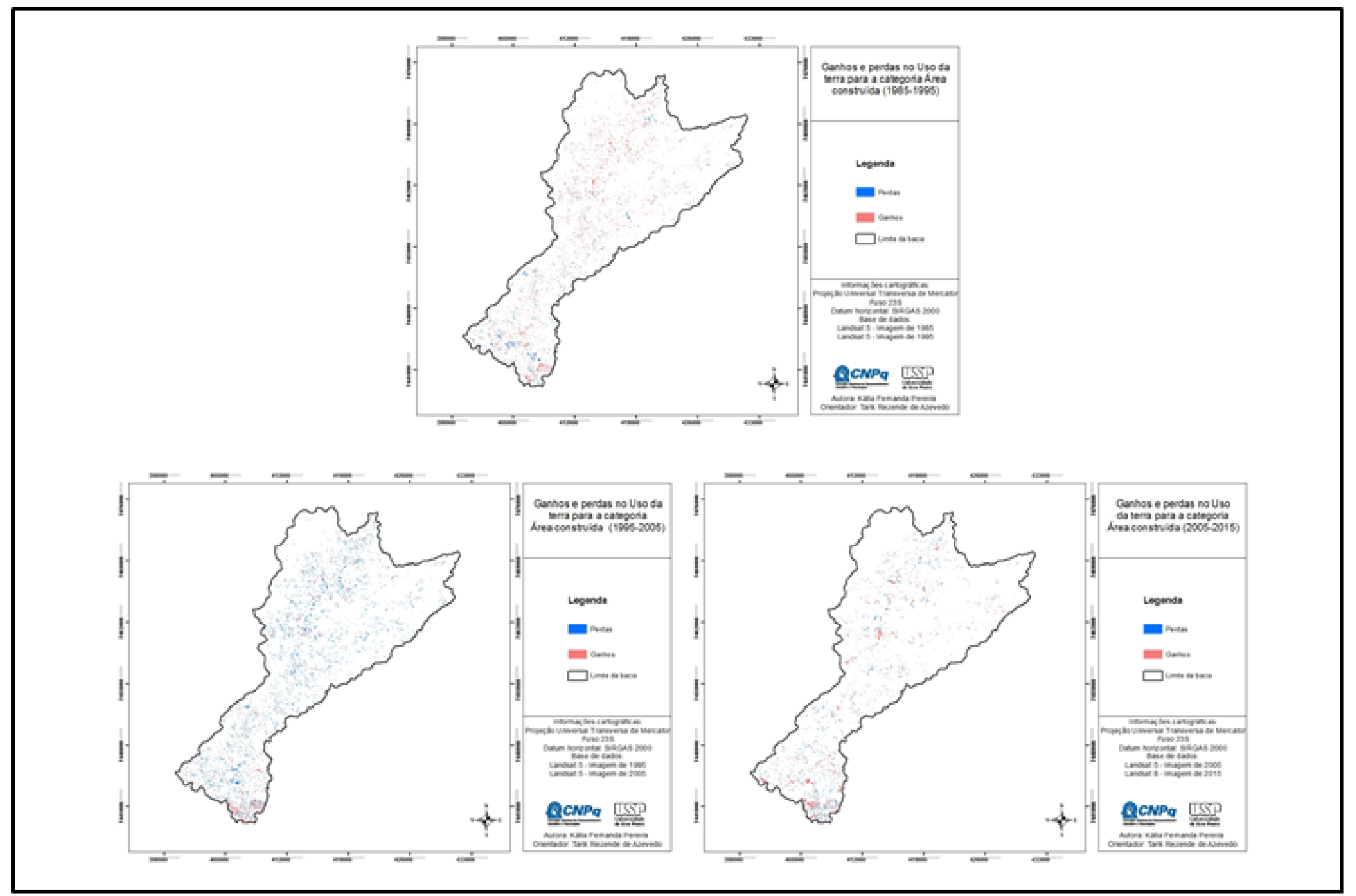

Fonte: Autora 


\subsubsection{Ganhos e perdas da terra para a categoria Pastagem}

A categoria pastagem apresentou uma grande representatividade na bacia nas épocas analisadas. A grande perda de área entre 1985 e 1995 da categoria se deu para a implantação de floresta primária. O maior ganho desta categoria foi sobre a classe vegetação secundária, como observamos no gráfico 6:

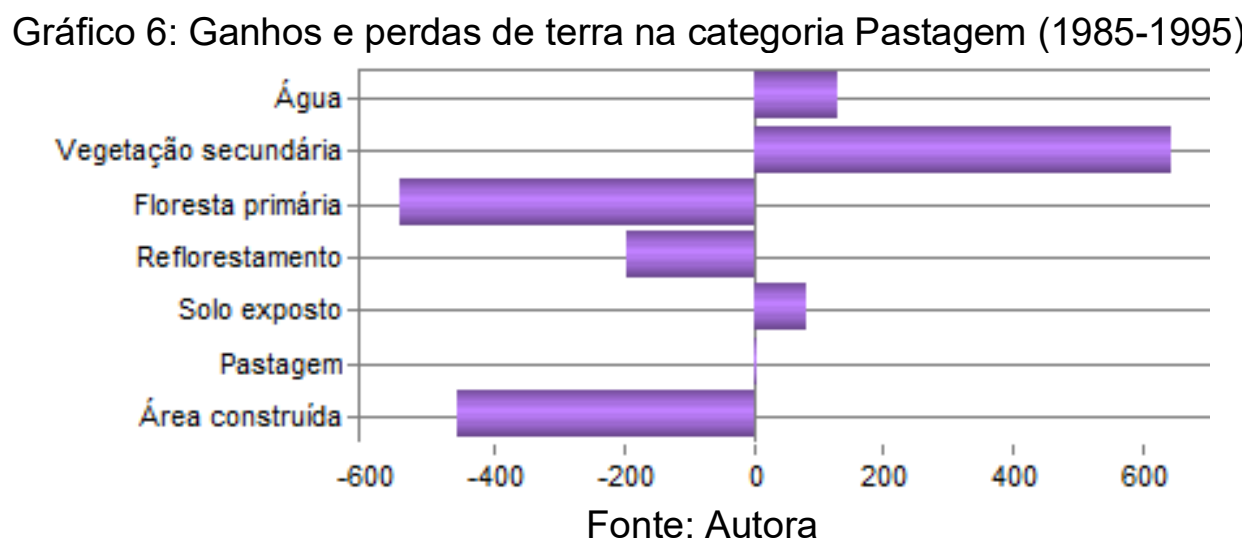

Com a abertura para outras categorias de cultivo, assim como as variações econômicas de cada época, a pastagem, destinada à pecuária na bacia acabou sendo substituída por outras distintas coberturas.

Espacializamos as perdas e ganhos da terra, na figura a seguir (figura 41): 
Figura 41: Mapa de ganho e perda na categoria Pastagem (1985-1995)

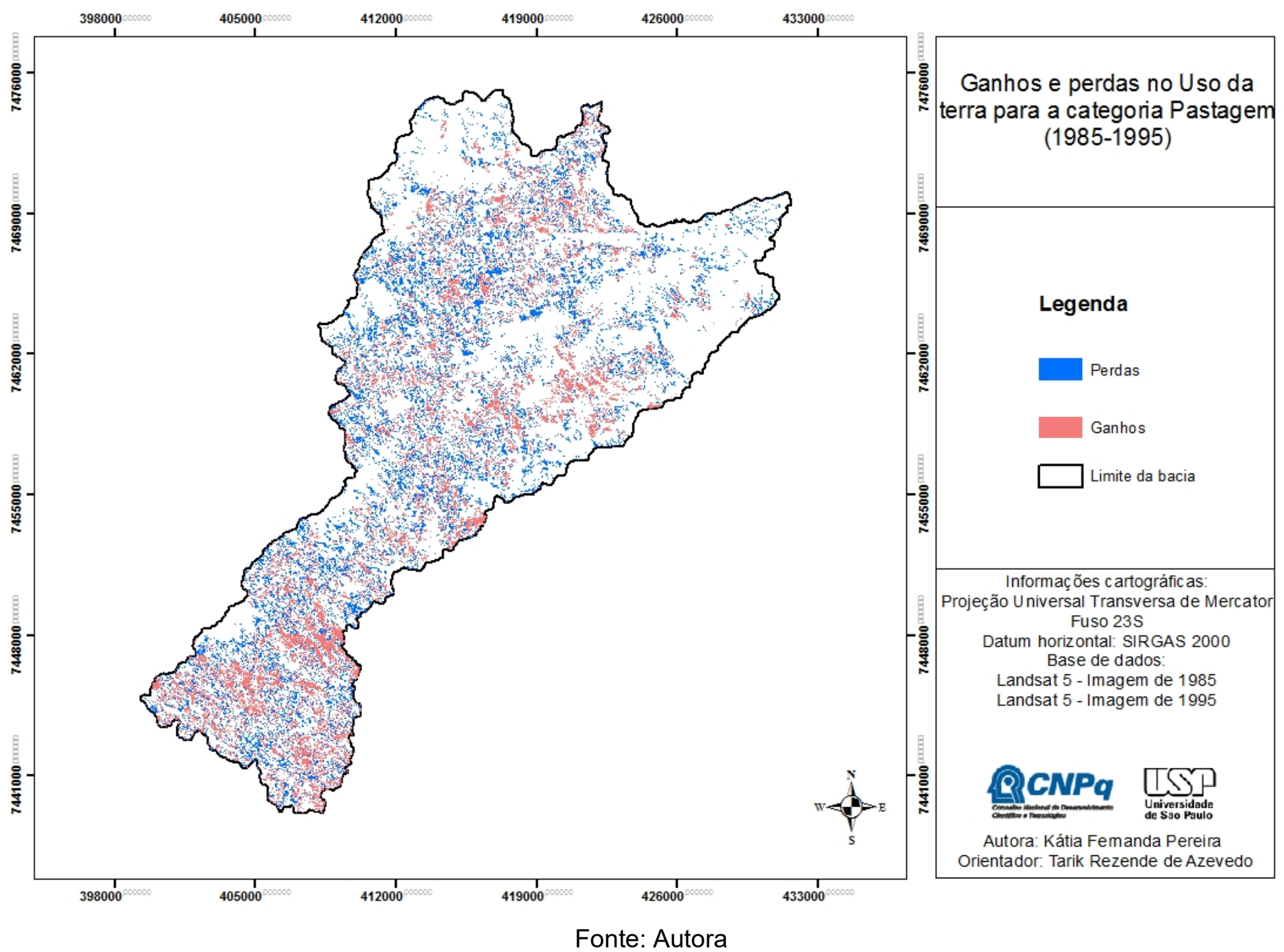


Nos anos de 1995 e 2005 (gráfico 7), o cenário encontrado foi o aumento de vegetação secundária, água e solo exposto e a diminuição de áreas de floresta primária, área construída e pequena parcela de reflorestamento sobre a classe pastagem. Este dado atenta ao fato de que houve um cuidado com o replantio de mudas e atenção às matas ciliares, entretanto, a supressão de mata nativa prosseguiu.

Gráfico 7: Ganhos e perdas de terra na categoria Pastagem (1995-2005)

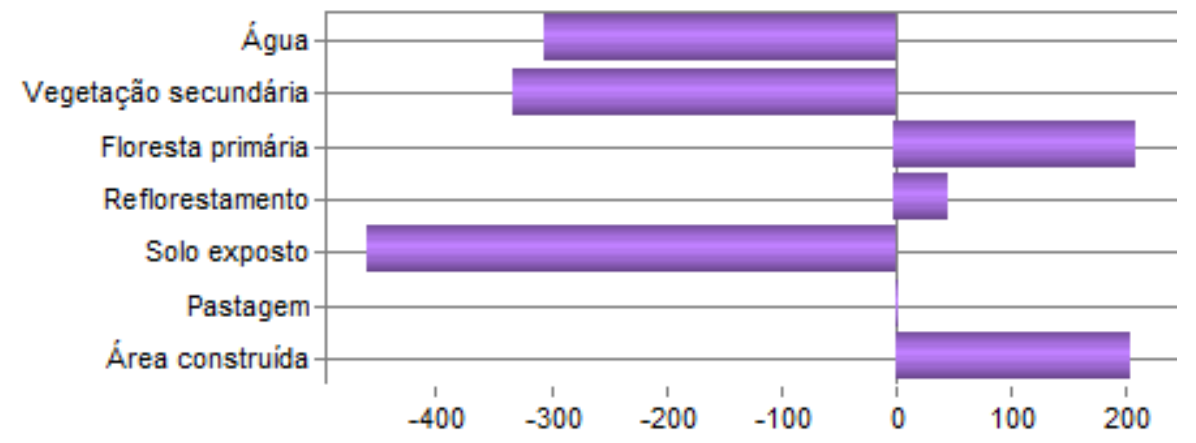

Fonte: Autora

No ano de 2005, a presença da pastagem continuava marcante na bacia, como observamos na carta de uso e cobertura da terra para este ano. A expressiva ocorrência desta categoria deve-se à pecuária de corte e leiteira, amplamente difundida no período, ligada aos fatores econômicos da época.

Espacializamos as perdas e ganhos da terra, na figura a seguir (figura 42): 
Figura 42: Mapa de ganho e perda na categoria Pastagem (1995-2005)

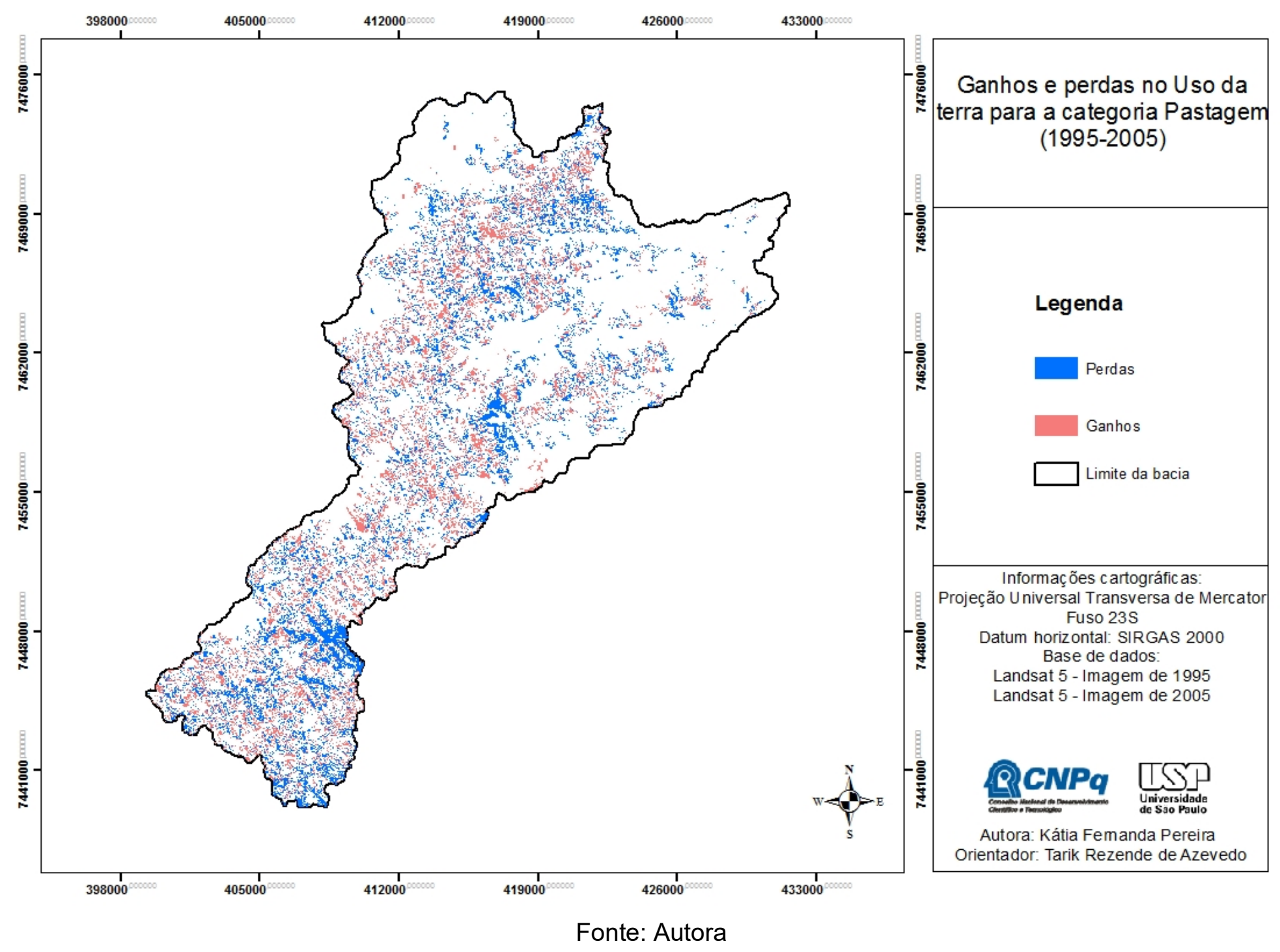


O gráfico da figura 40 revela que a categoria pastagem perdeu áreas, principalmente, para a vegetação secundária.

Gráfico 8: Ganhos e perdas de terra na categoria Pastagem (2005-2015)

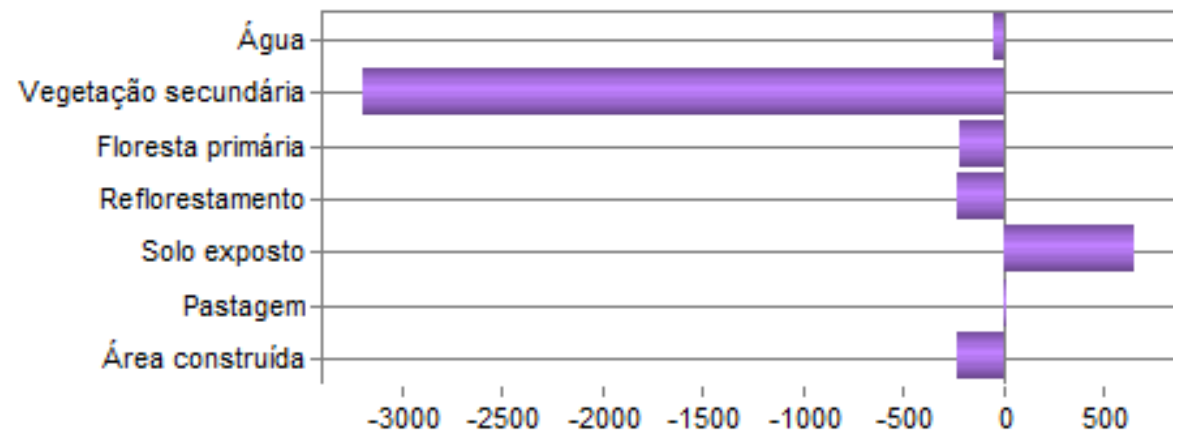

Fonte: Autora

O fator positivo na mudança dos usos está atrelado à perda da pastagem para coberturas como a floresta e vegetação secundária, uma vez que essas são vegetações salutares, que garantem o equilíbrio do ambiente.

Tais dados revelam que a economia da bacia sofreu modificações, contudo, ainda apresenta grande participação da pecuária, justificando as grandes extensões cultivadas com pastagem.

As áreas de perdas e ganhos na terra, para esta categoria, estão representadas na figura 43 , e na sequência, apresentamos os mapas comparativos de LCM (quadro 2). 
Figura 43: Mapa de ganho e perda na categoria Pastagem (2005-2015)

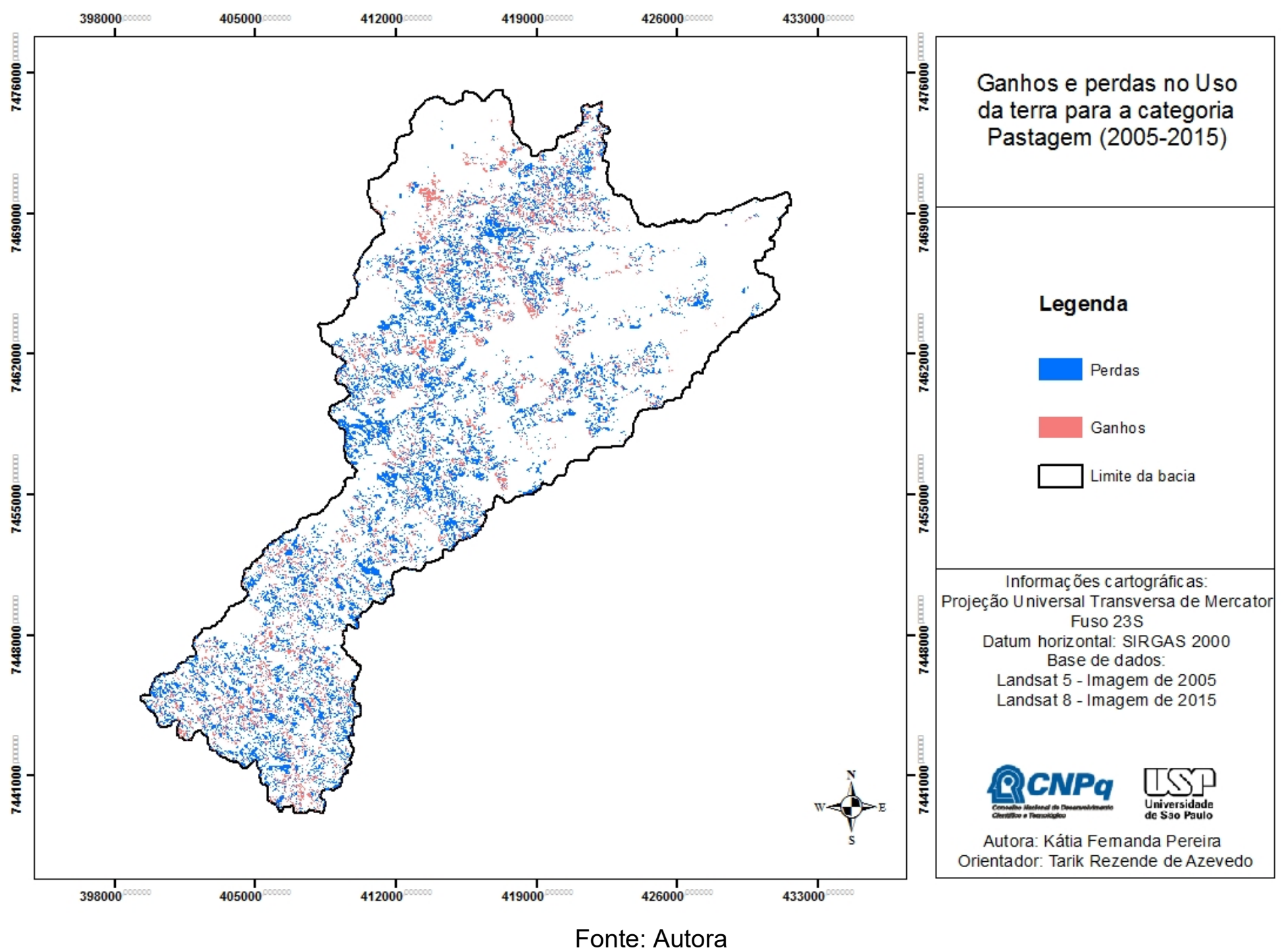


155

Quadro 2: Comparação dos mapas de ganhos e perdas na área da bacia para a categoria Pastagem
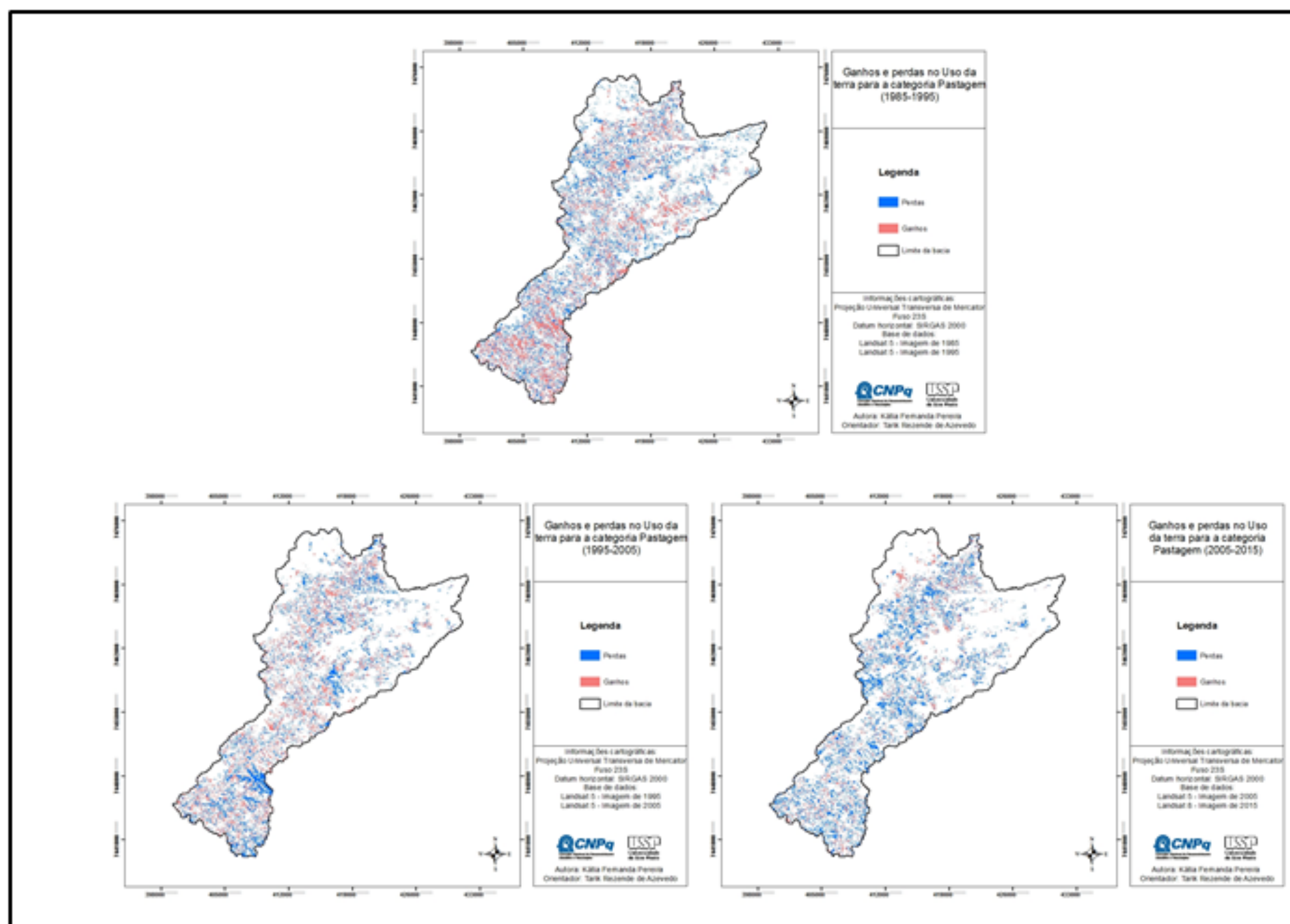

Fonte: Autora 


\subsubsection{Ganhos e perdas da terra para a categoria Solo exposto}

Para esta categoria, consideramos a classificação dos solos descobertos ou as que indicavam formatos, com condições texturais e cores referentes à culturas agrícolas. Com base nos trabalhos de campo, pode-se concluir que algumas destas áreas que correspondiam a cultivos, possuíam plantações como algodão, milho e feijão.

Como o período de plantio destes cultivos, segundo o calendário agrícola, é realizado no mês de outubro - e as imagens de satélite são provenientes do mês de setembro e outubro - concluímos que, em alguns pontos, o replantio ainda não havia ocorrido.

A categoria solo exposto, entre os anos de 1985 e 1995, perdeu áreas para a vegetação secundária, floresta primária, reflorestamento, pastagem, área construída e substituiu pequena área de água, como visto no gráfico a seguir (gráfico 9):

Gráfico 9: Ganhos e Perdas de terra na categoria Solo exposto (1985-1995)

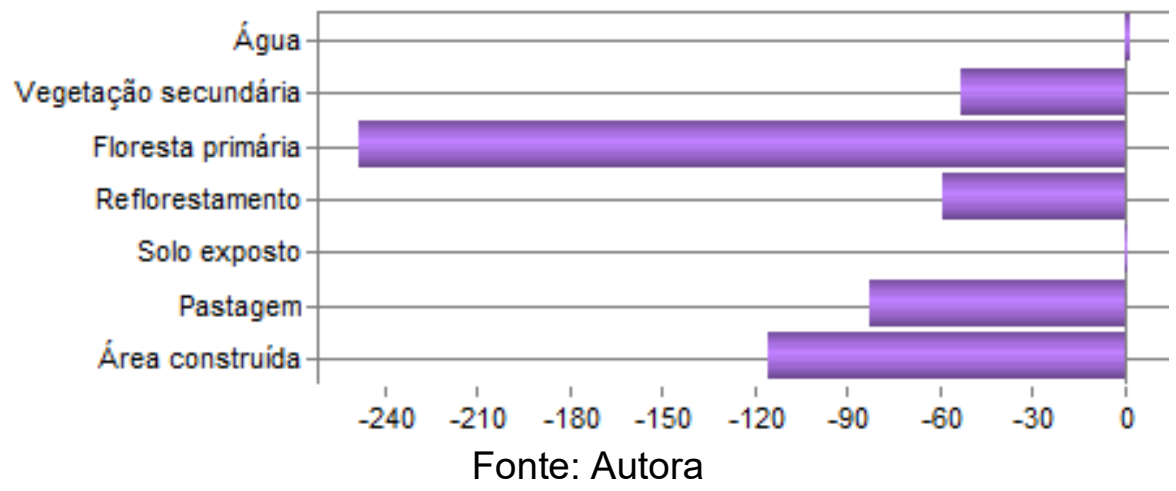

Espacializamos as perdas e ganhos da terra, na figura 44: 
Figura 44: Mapa de ganho e perda na categoria Solo exposto (1985-1995)

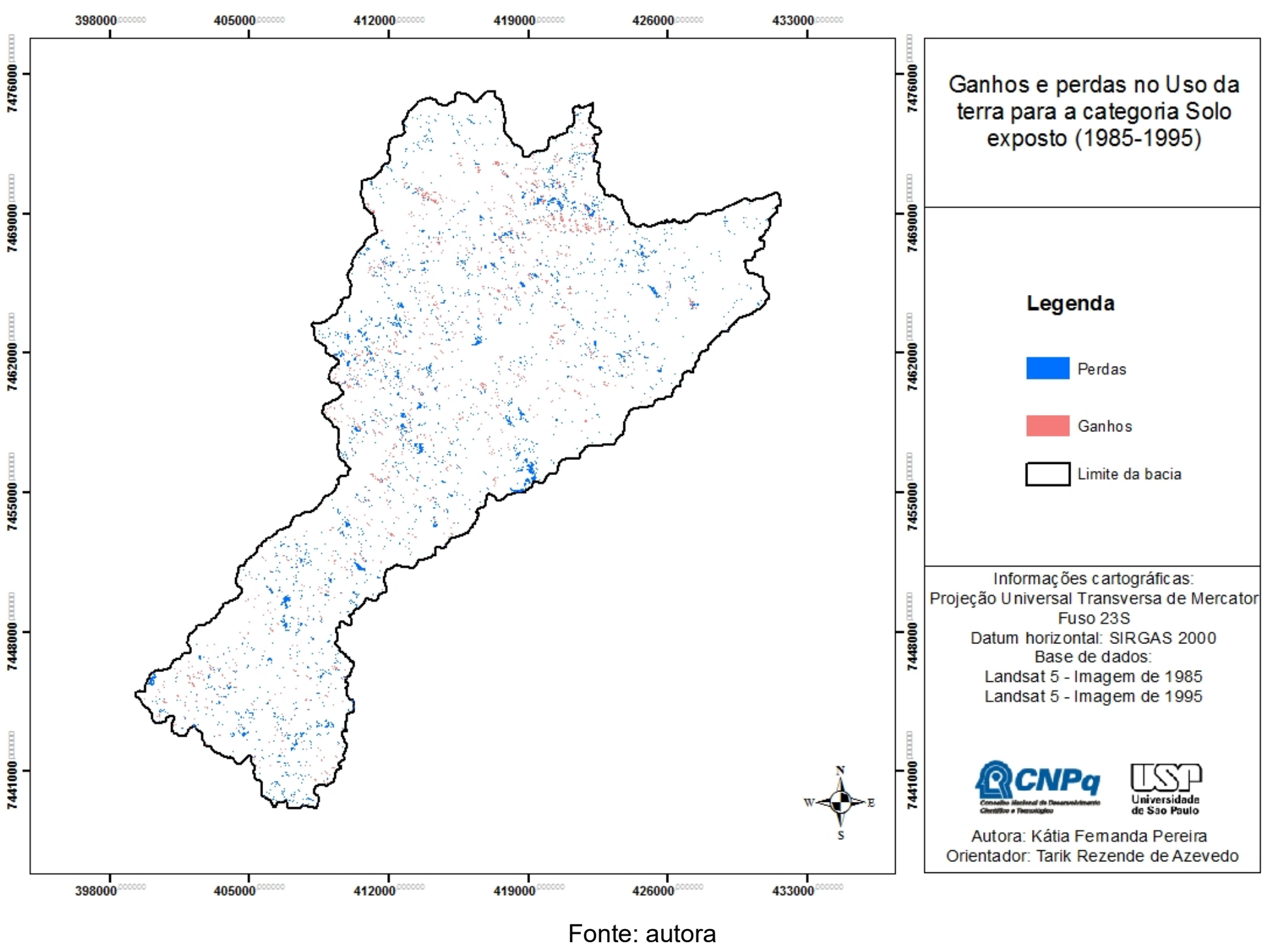


Para os anos entre 1995 e 2005, observamos que o solo exposto ganhou áreas, principalmente, sobre a categoria pastagem e vegetação secundária. O avanço do solo exposto/cultura temporária sobre a vegetação secundária foi considerado um ponto negativo, pois como já dito anteriormente, a perda das coberturas naturais para qualquer outra cobertura resulta em perda para o ambiente natural.

Gráfico 10: Ganhos e perdas de terra na categoria Solo exposto (1995-2005)

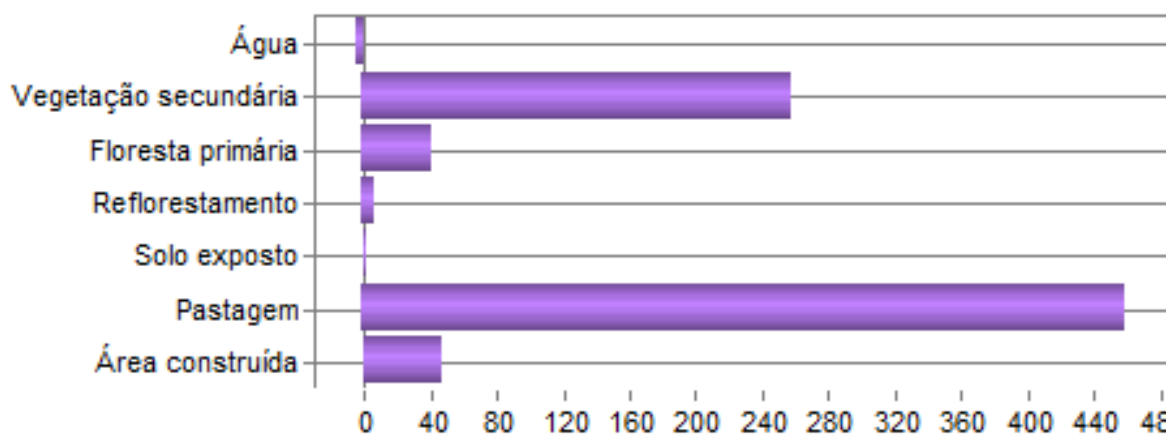

Espacializamos as perdas e ganhos da terra, na figura a seguir (figura 45): 
Figura 45: Mapa de ganho e perda na categoria Solo exposto (1995-2005)

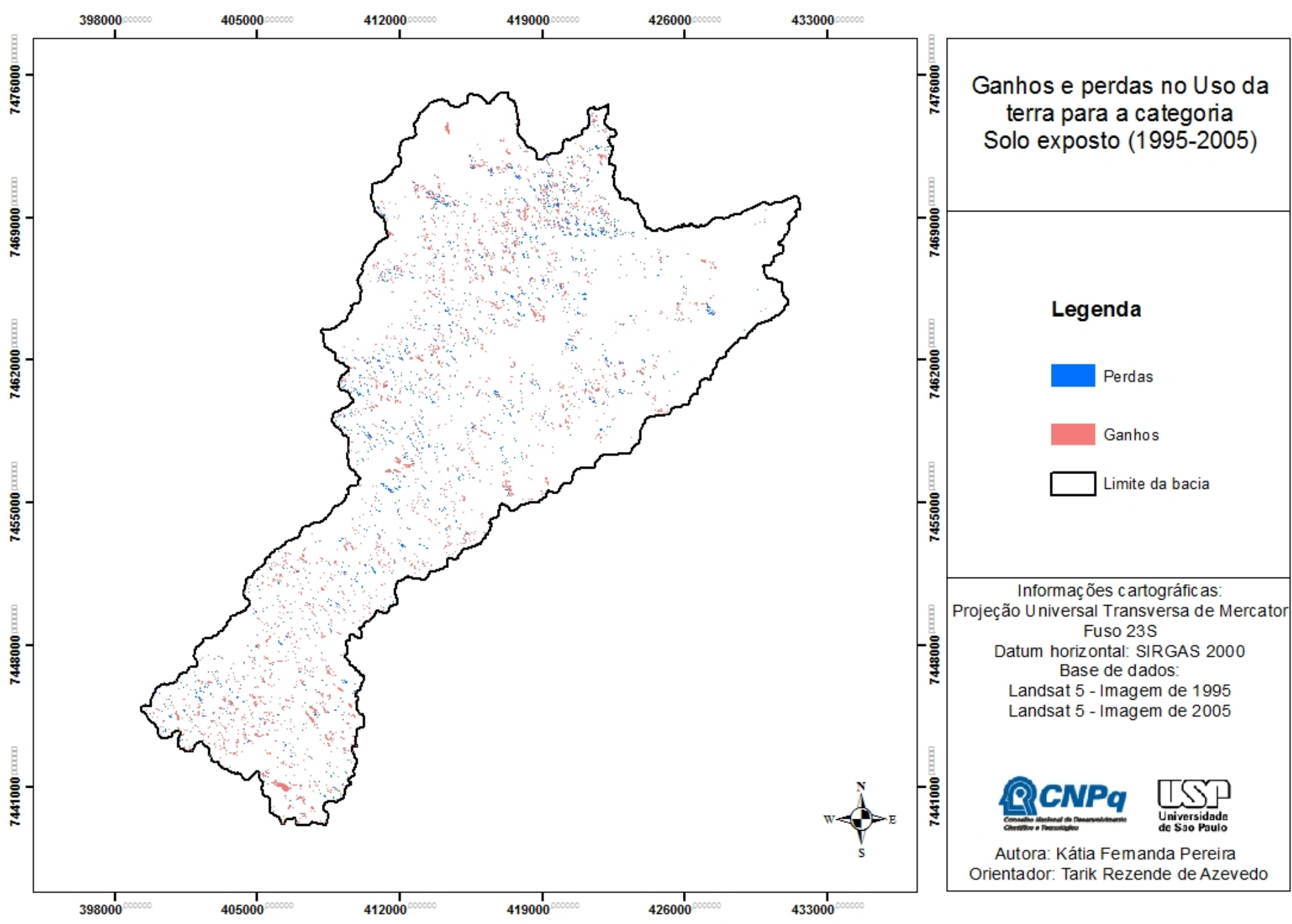

Fonte: autora 
Entre 2005 e 2015, constatamos que o solo exposto não avançou substancialmente sobre a área da bacia. As categorias de plantio e solo descoberto não só mantiveram uma porção do território, como também, retrocederam. Vegetação secundária e pastagem substituíram, em suma, grande parte deste uso, como observamos no gráfico 11:

Gráfico 11: Ganhos e perdas de terra na categoria Solo exposto (2005-2015)

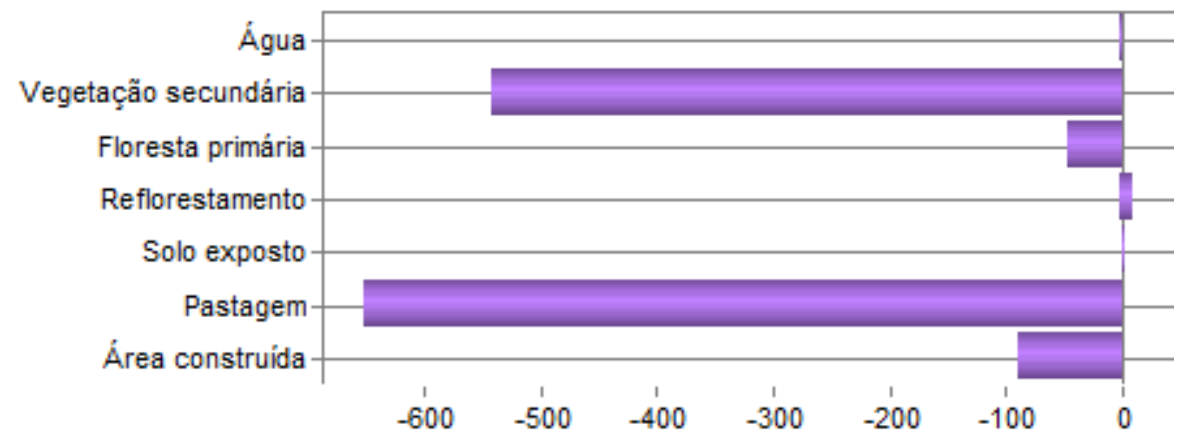

Fonte: Autora

O plantio de cultivos temporários possui variação nas determinadas épocas do ano, bem como, o feedback econômico dado por cada cultura, onde o produtor acaba sempre optando pelo plantio mais lucrativo para sua propriedade.

As áreas de ocupação desta categoria estão representadas na figura 46 e o quadro comparativo entre todos os mapas para esta categoria estão expostos no quadro 3: 
Figura 46: Mapa de ganho e perda na categoria Solo exposto (2005-2015)

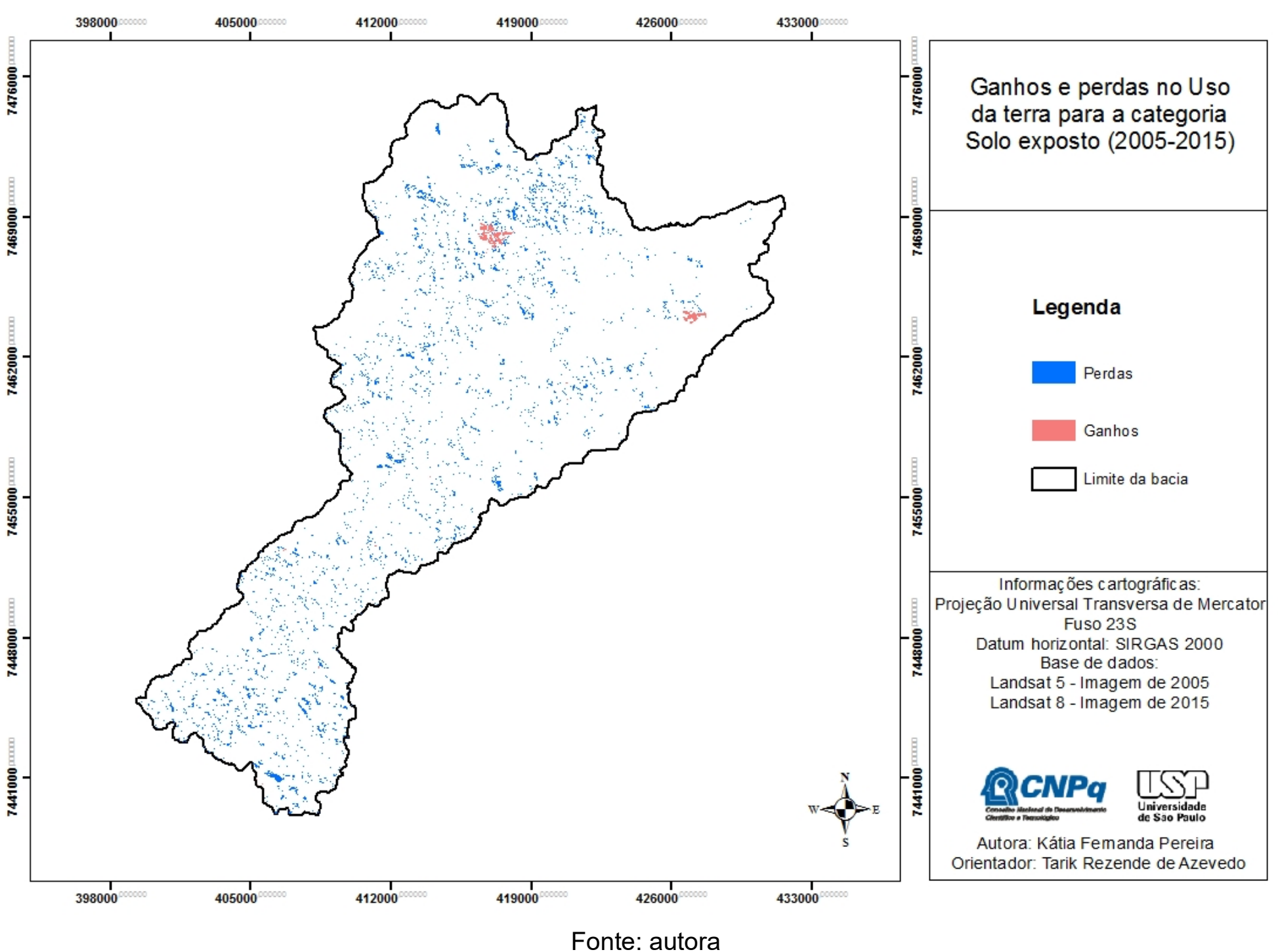


Quadro 3: Comparação dos mapas de ganhos e perdas na área da bacia para a categoria Solo exposto

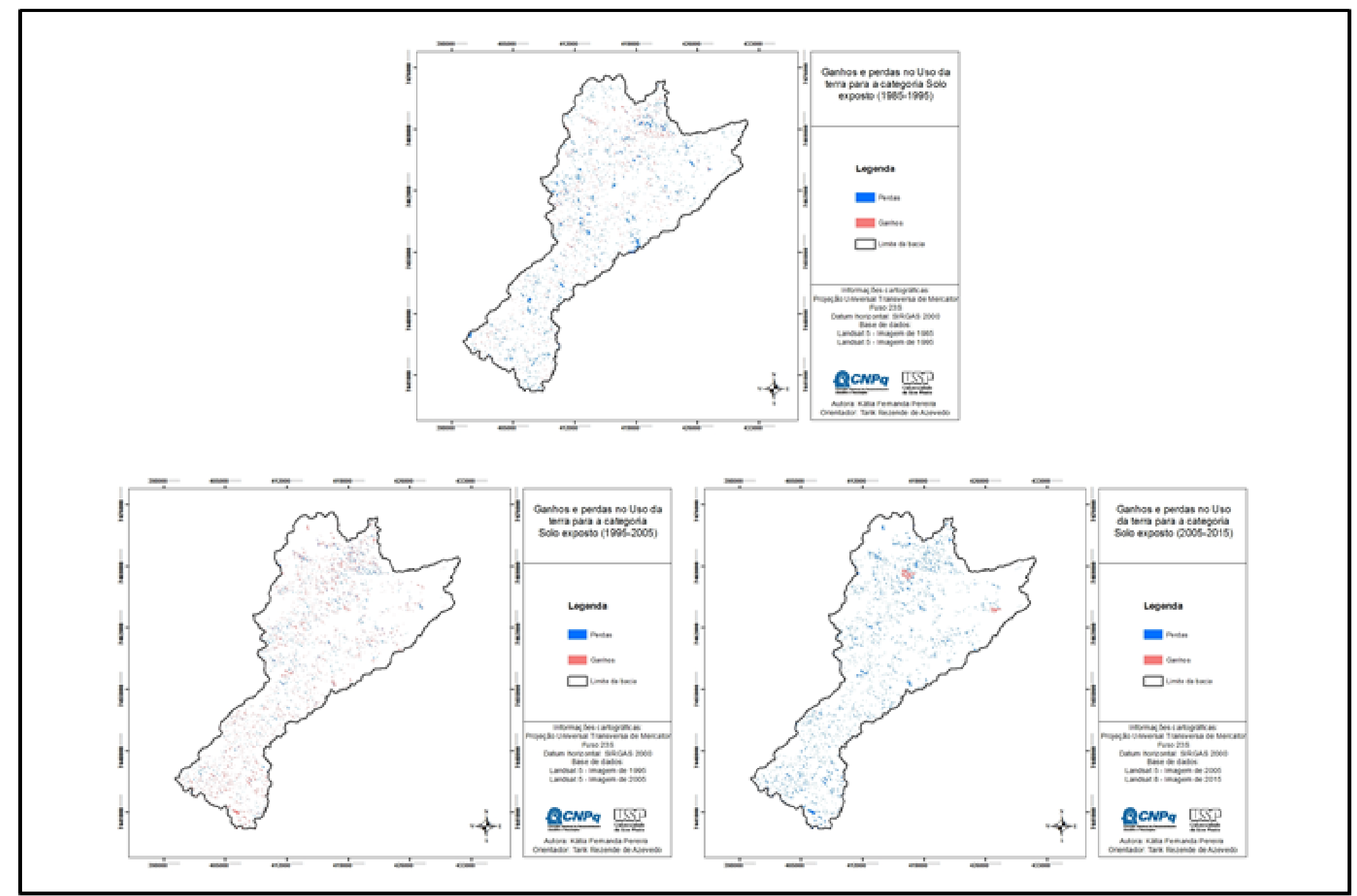

Fonte: Autora 


\subsubsection{Ganhos e perdas da terra para a categoria Reflorestamento}

A categoria reflorestamento mostra-se expressiva na área de estudo. Esse cultivo está relacionado às plantações de eucalipto e pinus, com destino à produção de madeira e de papel e celulose, e vem aumentando sua representatividade na região em razão à grande demanda dos produtos derivados dessa categoria de cultivo, fazendo com que seu valor de comercialização seja atrativo para os proprietários rurais da bacia.

Observando o gráfico a seguir, para os anos de 1985 a 1995, vemos que esta categoria cresceu abruptamente sobre determinadas áreas, demonstrando que a situação econômica do período alavancara a produção para alta comercialização. A categoria despontou sobre as áreas de vegetação secundária, floresta primária e pastagem (gráfico 12):

Gráfico 12: Ganhos e perdas de terra na categoria Reflorestamento (1985-1995)

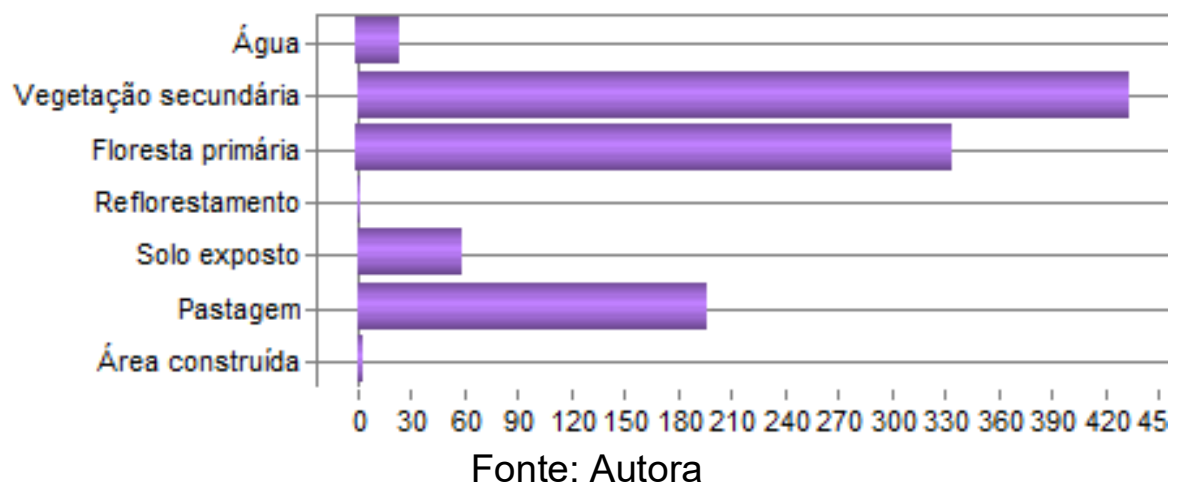

Espacializamos as perdas e ganhos da terra, na figura a seguir (figura 47): 
Figura 47: Mapa de ganho e perda na categoria Reflorestamento (1985-1995)

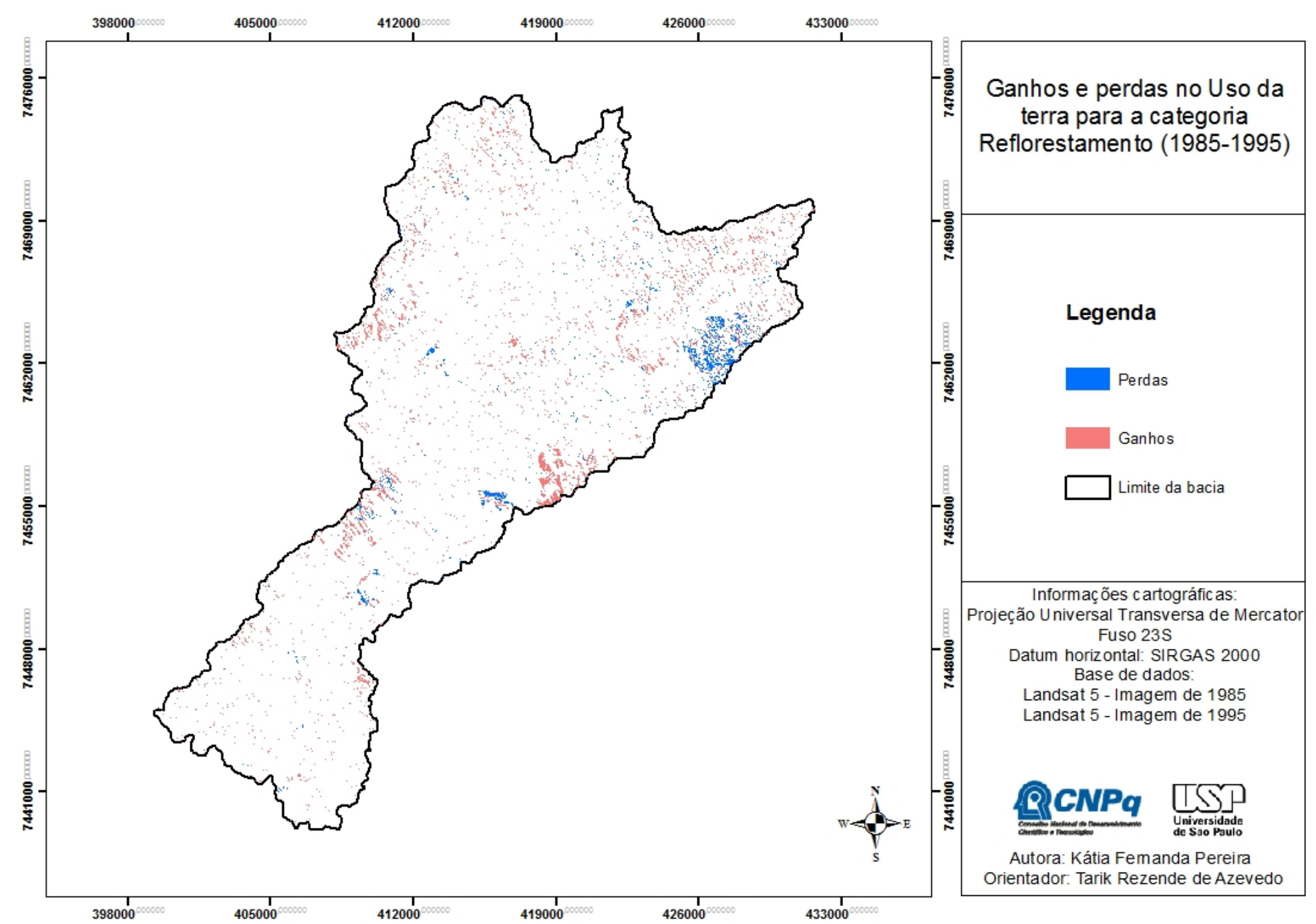

Fonte: Autora 
O reflorestamento é uma categoria de uso que tem emergido, não só em Monteiro Lobato, mas em toda a região do Vale do Paraiba, principalmente pelas altas declividades na área da bacia - o que dificulta outras produções agropecuárias e favorece a produção do eucalipto. Ademais, os agricultores enxergam no reflorestamento uma nova opção de obtenção de renda, que pode ser maior em relação às outras atividades agrícolas.

Em contramão ao crescimento desta atividade, gera-se uma grande discussão sobre a prática deste cultivo para a produção de celulose, devido aos impactos ambientais causados pela plantação do eucalipto. Dentre os impactos negativos, citamos: a erosão e empobrecimento do solo, rebaixamento de lençóis freáticos, desaparecimento de nascentes e alteração na biodiversidade local, exigindo medidas para minimizar e recuperar as áreas rurais da região.

Assim, para os anos de 1995-2005, observamos que a reflorestamento obteve ganhos de terra, sobre a categoria floresta primária, reforçando um ponto negativo dos reflorestamentos: a prática indiscriminada de supressão de florestas naturais.

Gráfico 13: Ganhos e perdas de terra na categoria Reflorestamento (1995-2005)

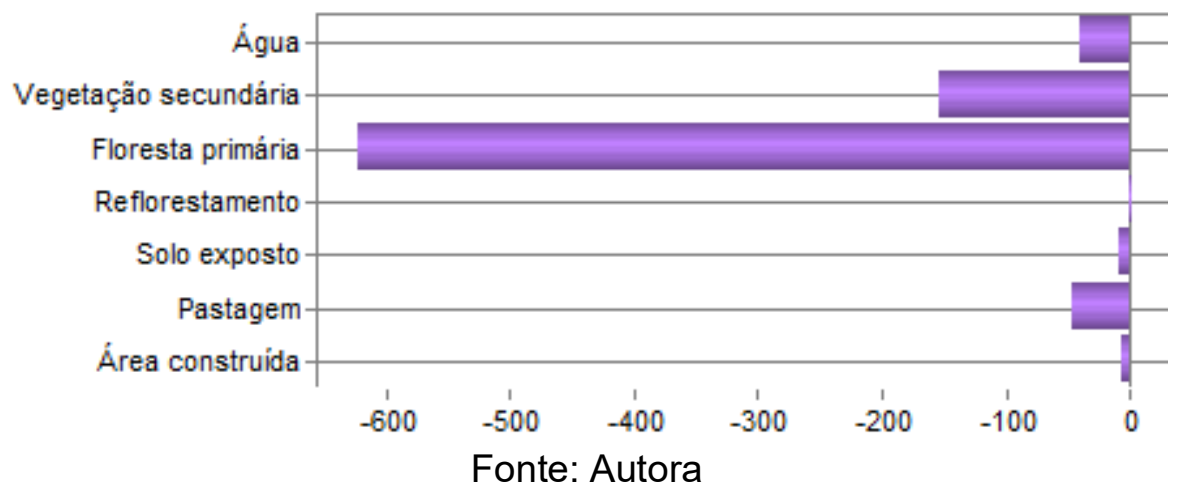

A seguir, espacializamos as perdas e ganhos da terra, na figura 48: 
Figura 48: Mapa de ganho e perda na categoria Reflorestamento (1995-2005)

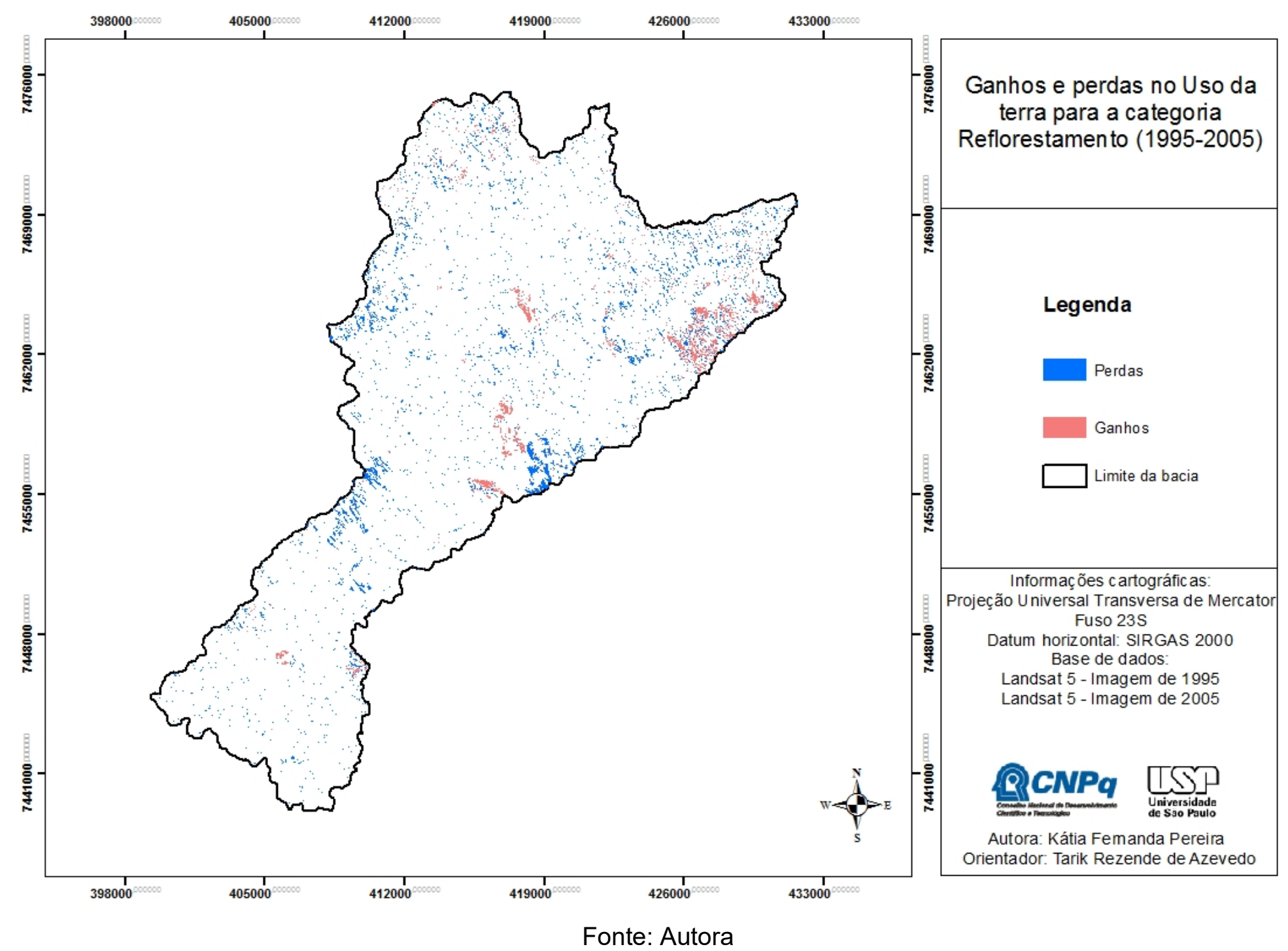


Para os anos entre 2005-2015, notamos que a categoria reflorestamento apresentou um ganho de terras considerável em cima das categorias vegetação secundária, pastagem e, principalmente, sobre florestas primárias, como consideramos no gráfico 14:

Gráfico 14: Ganhos e perdas de terra na categoria Reflorestamento (2005-2015)

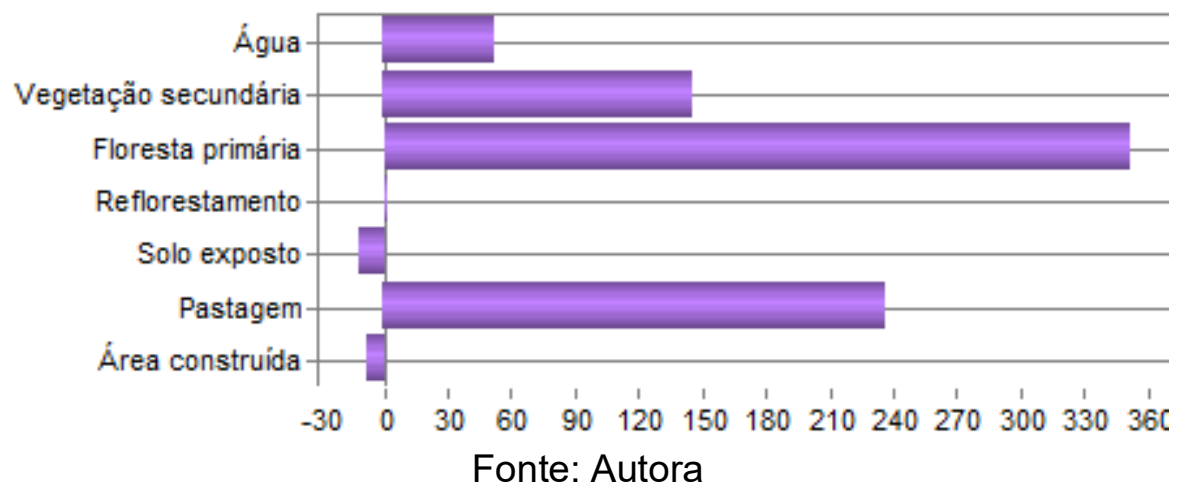

O projeto chamado Corredor Ecológico do Vale do Paraíba, é uma ação que tem o intuito de resgatar toda porção de floresta primária "perdida" ao longo dos anos, por atos predatórios na bacia. Esta iniciativa prevê o plantio de mais de 10 milhões de árvores até 2020, reconectando aproximadamente 150 mil hectares de fragmentos isolados de Mata Atlântica em propriedades privadas e públicas.

As mudanças ocorridas nesse período estão registradas na figura 49, a qual espacializa as áreas onde ocorreram perda e ganho relacionadas à categoria, juntamente ao quadro 4, apresentando a comparação de todos os anos. 
Figura 49: Mapa de ganho e perda na categoria Reflorestamento (2005-2015)

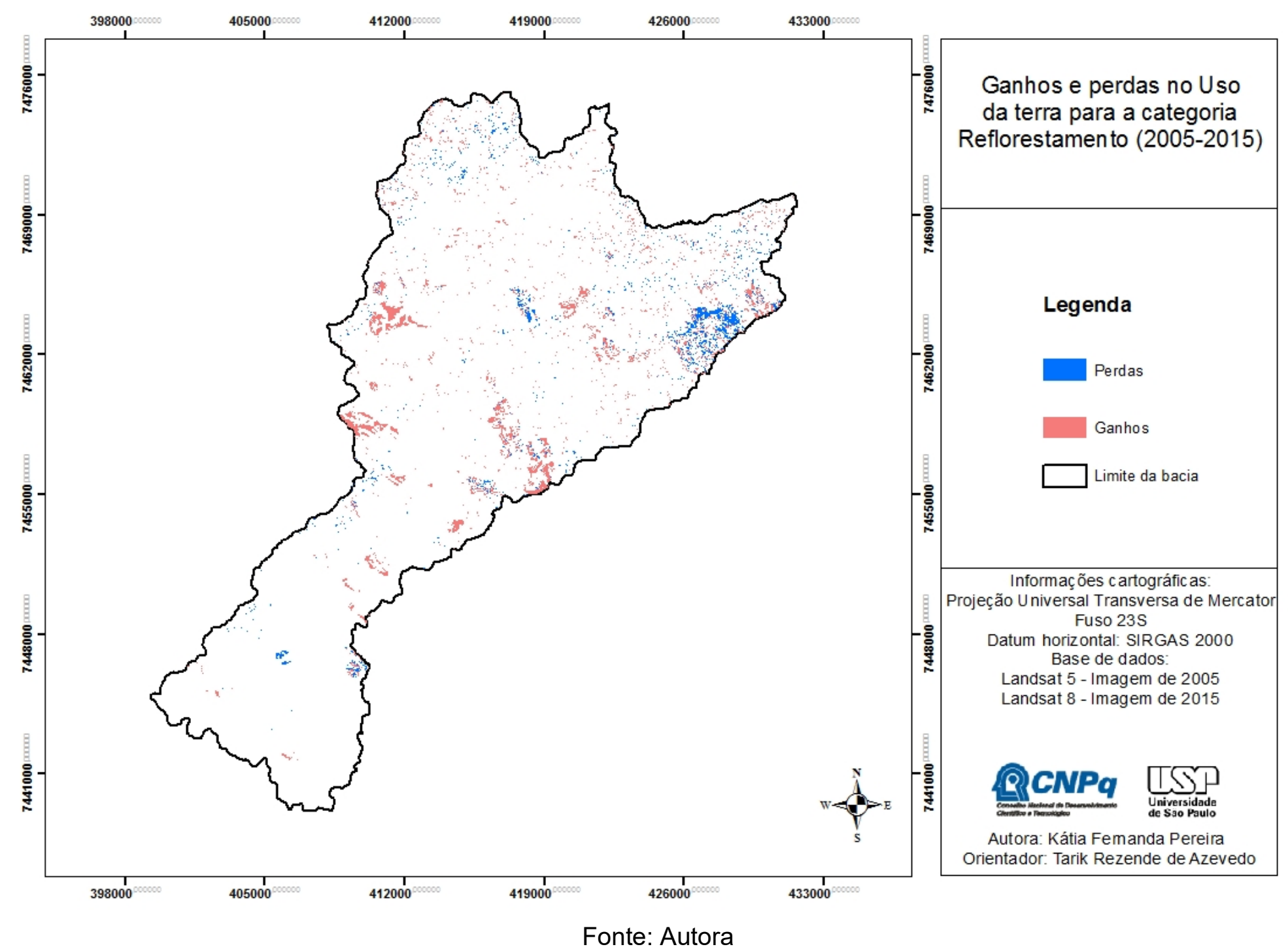


Quadro 4: Comparação dos mapas de ganhos e perdas na área da bacia para a categoria Reflorestamento

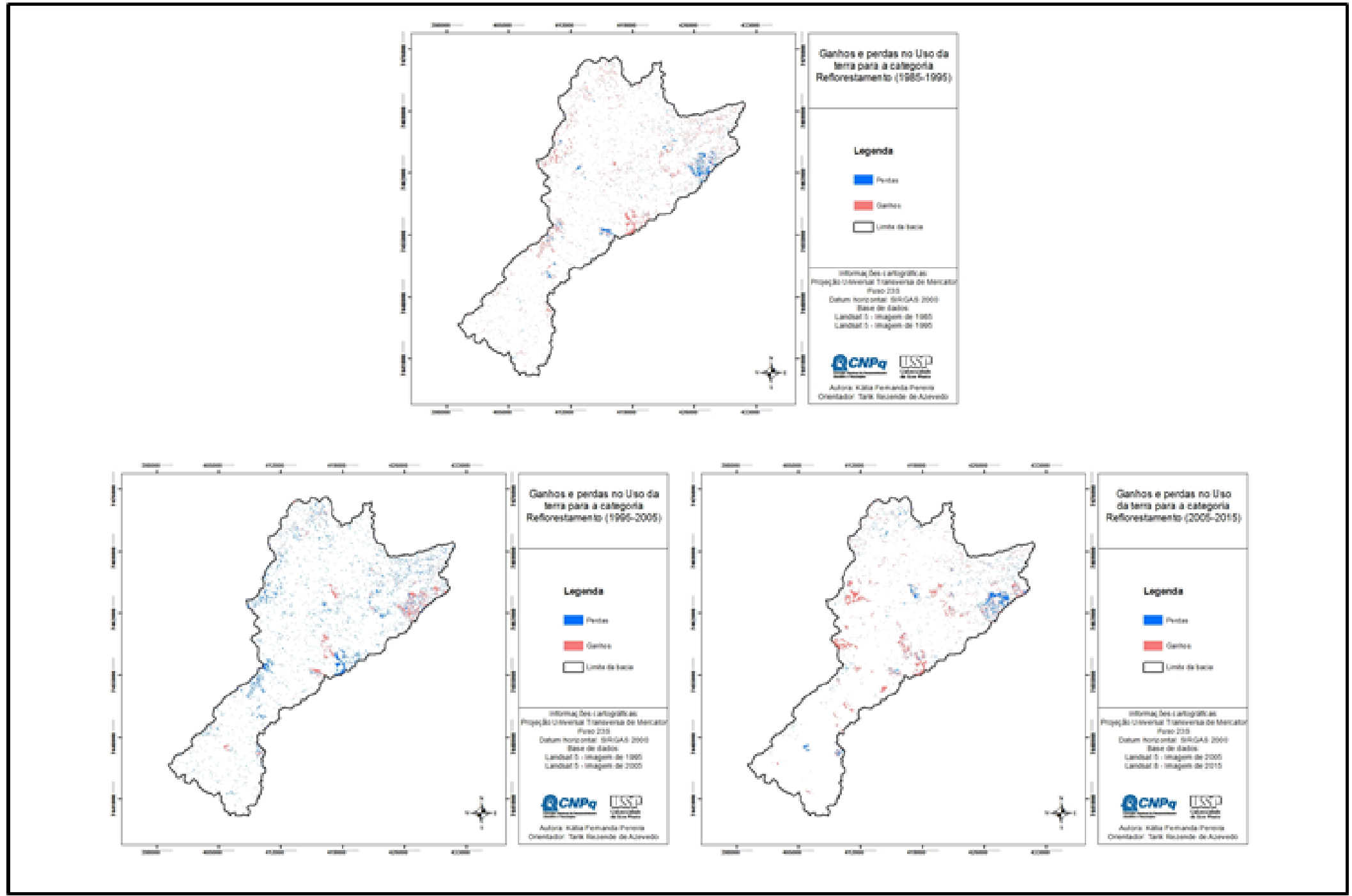

Fonte: Autora 


\subsubsection{Ganhos e perdas da terra para a categoria Floresta primária}

A formação vegetal predominante na categoria Floresta primária é de floresta estacional semidecídua (Mata Atlântica), caracterizada pela perda de parte das folhas (20 a 50\%) nos períodos secos podendo ser dividida em floresta de terras baixas, submontana e montana (IBGE, 2012)

As plantações mais significativas são de araçá, jabuticaba, canela preta, cafezinho do mato, figueira branca, dentre outras.

Para esta categoria devemos considerar as transformações inerentes que ocorrem em áreas de vegetação. Para uma análise mais aprofundada, voltada ao mapeamento, monitoramento e proteção de áreas de vegetação, salientamos que imagens com maiores resoluções e a utilização de índices de vegetação oferecem resultados mais concisos. Entretanto, para a finalidade deste trabalho, a classificação supervisionada nas imagens Landsat com a resolução de $30 \mathrm{~m}$, juntamente aos trabalhos de campo foram eficientes para a comparação da transformação das áreas de floresta primária ao longo dos anos.

Segundo os seguintes dados para os anos de 1985-1995, parte da categoria floresta foi revertida em reflorestamento e área construída, o que é relacionado com o crescimento do desmatamento da vegetação natural.

A categoria Florestal teve aumento sobre as áreas de vegetação secundária e pastagem, e interpretamos positivamente este fato. Esta categoria é essencial para assegurar a proteção dos recursos hídricos e solo, das espécies e do micro-clima da região. 
Gráfico 15: Ganhos e perdas de terra na categoria Floresta primária (1985-1995)

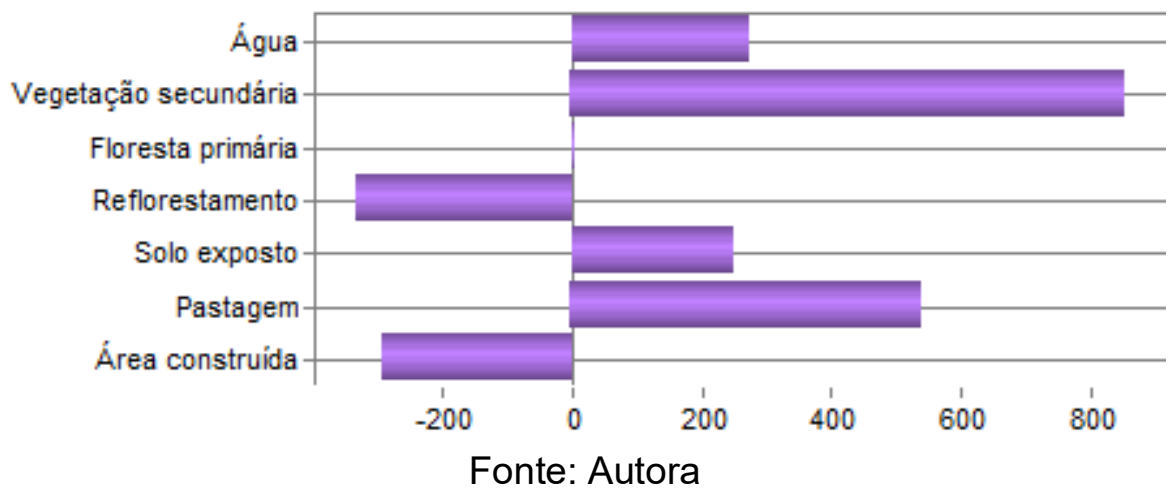

Espacializamos as perdas e ganhos da terra, na figura a seguir (figura 50) 
Figura 50: Mapa de ganho e perda na categoria Floresta primária (1985-1995)

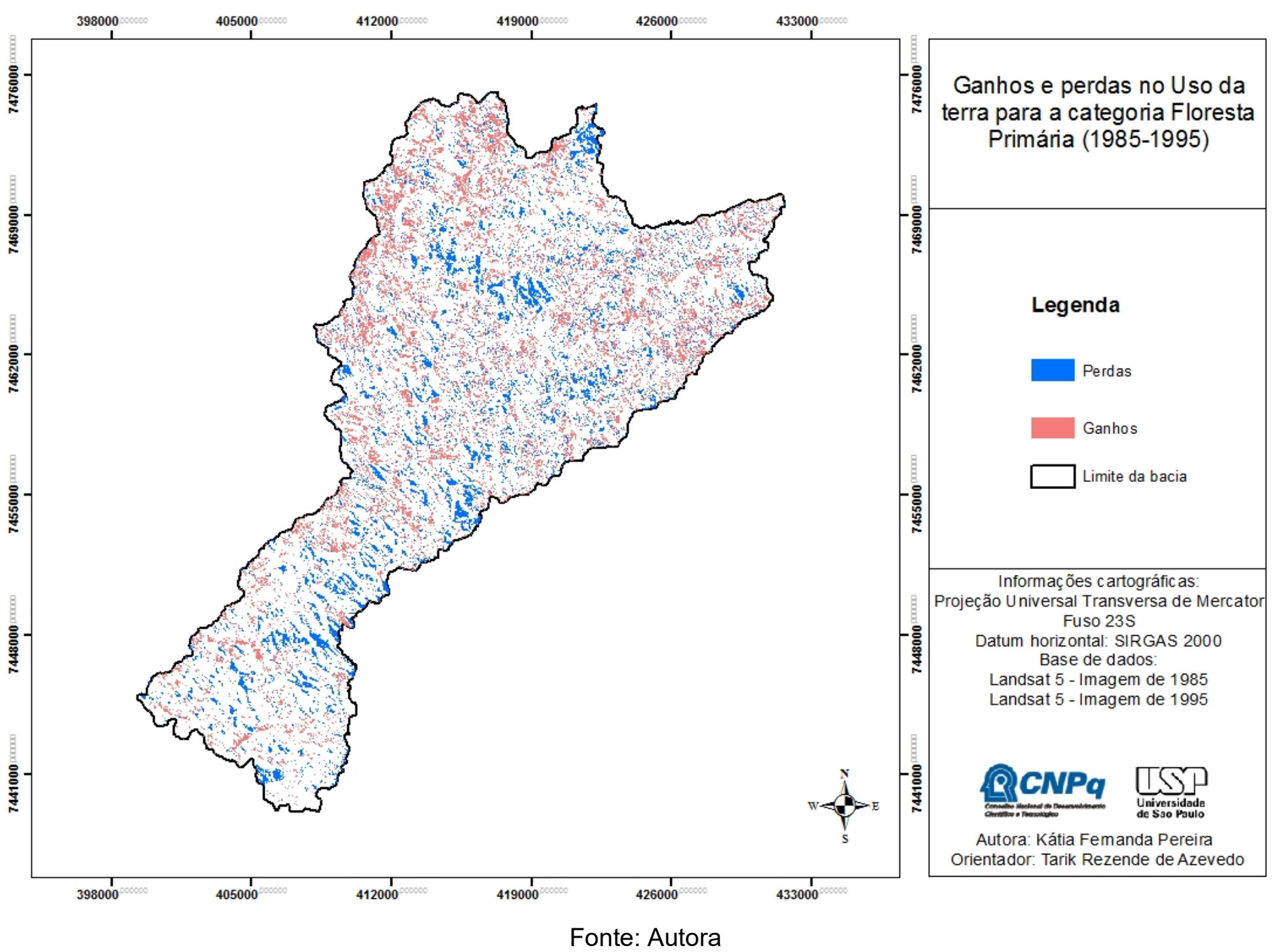


Nos anos entre 1995 e 2005, o cenário evidencia que houve desmatamento, principalmente para destinação das terras à água (uma das razões seria a preexistência de cursos d'água abaixo da cobertura florestal. Com a supressão da mata, esta classe se tornaria visível na imagem) e à vegetação secundária. Essas características podem ser percebidas no gráfico a seguir (gráfico 16)

Gráfico 16: Ganhos e perdas de terra na categoria Floresta primária (1995-2005)

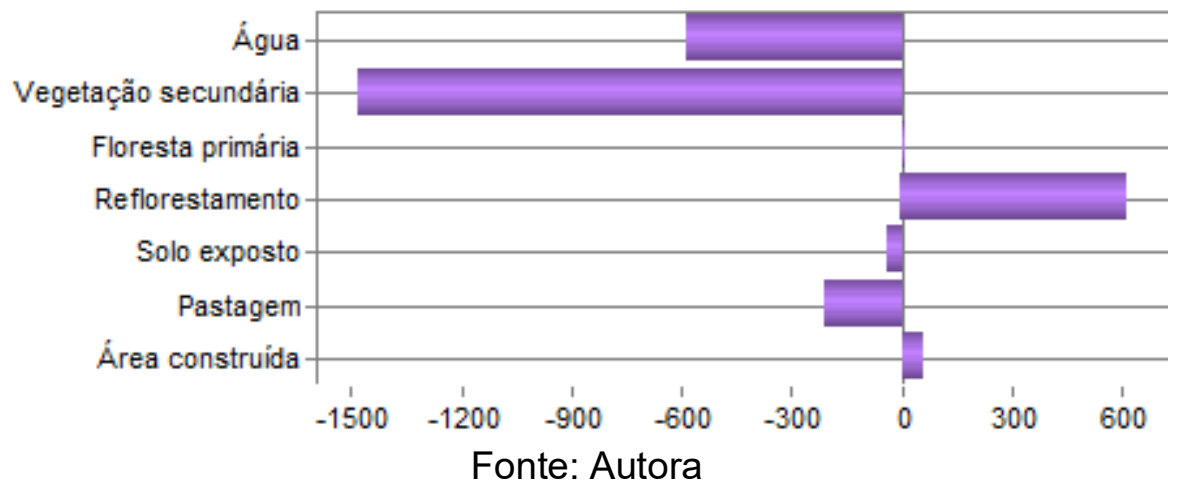

É um fato agravante quando o desmatamento afeta as áreas de preservação permanente, pois os prejuízos advindos desta situação vão refletir diretamente do corpo hídrico. Houve a constatação dos impactos negativos na área da bacia como o assoreamento, o carreamento de resíduos orgânicos e inorgânicos para o curso d’água e a contaminação da água.

Muitos esforços vêm sendo empregados para a recomposição da mata ciliar em forma de corredor ecológico, para também ampliar a biodiversidade local e de espécies como o chamado "muriqui", muito presente na região.

Esta categoria, mesmo com sua grande importância, acaba sendo a primeira área a ser manipulada com as mudanças da economia. Assim grande parte da vegetação, não só da área em questão, foram suprimidas em benefício do suposto progresso econômico. 
Espacializamos as perdas e ganhos da terra, na figura a seguir (figura 51): 
Figura 51: Mapa de ganho e perda na categoria Floresta primária (1995-2005)

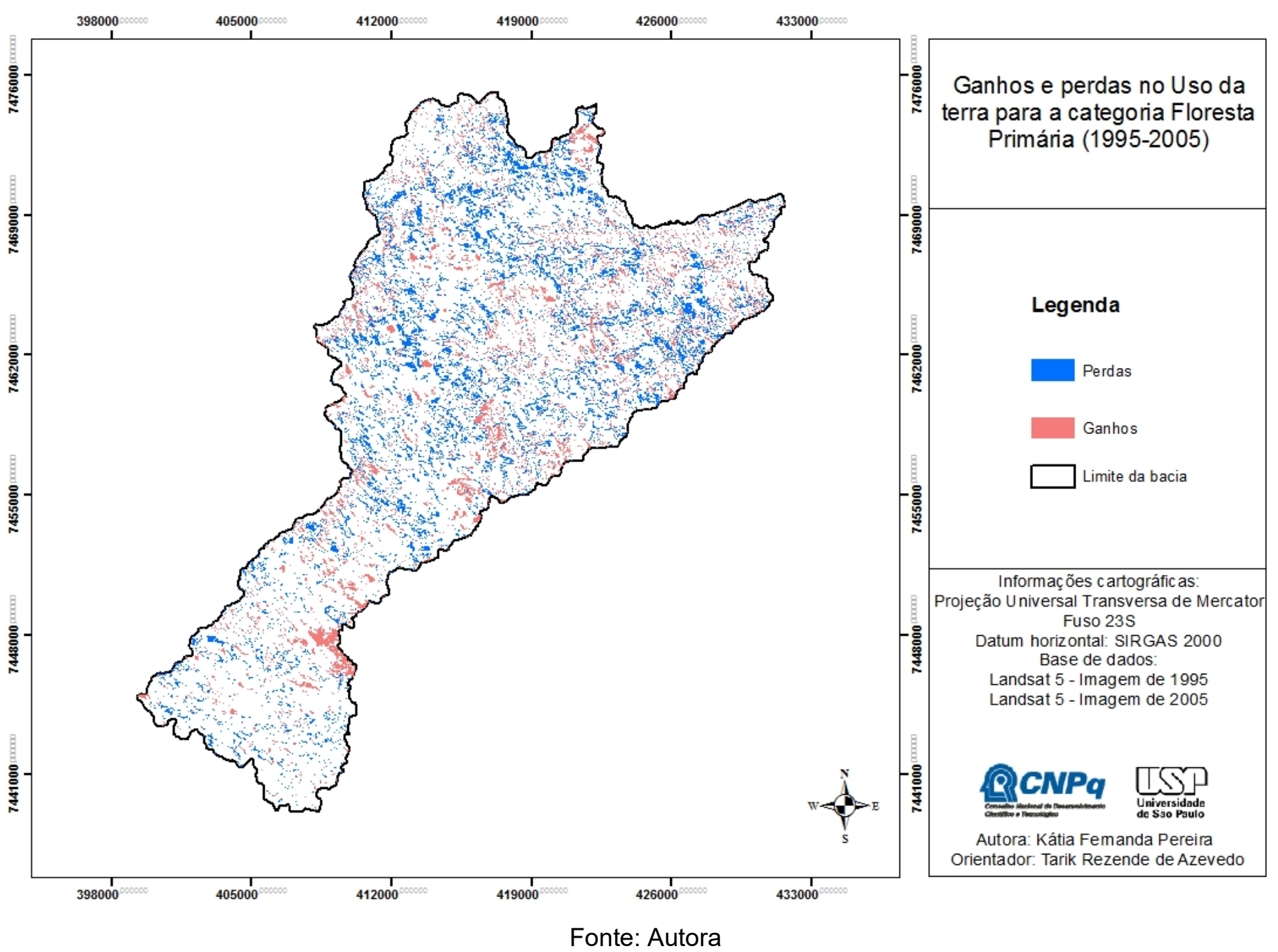


Nos anos de 2005-2015, observa-se uma mudança da visão sobre a floresta primária. Esta passa a crescer sobre áreas de pastagem, vegetação secundária, água e solo exposto.

Gráfico 17: Ganhos e perdas de terra na categoria Floresta primária (2005-2015)

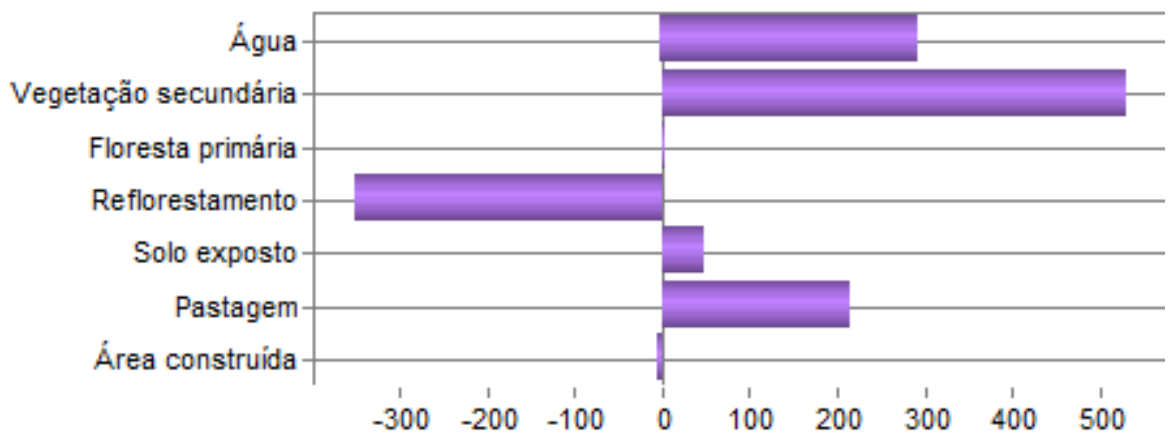

Fonte: Autora

Após as mudanças ocorridas entre 2005 e 2015, observamos a espacialização de ganhos e perdas de terra representada na figura 52 . No quadro 5 temos a comparação das perdas e ganhos para este período estudado. 
Figura 52: Mapa de ganho e perda na categoria Floresta primária (2005-2015)

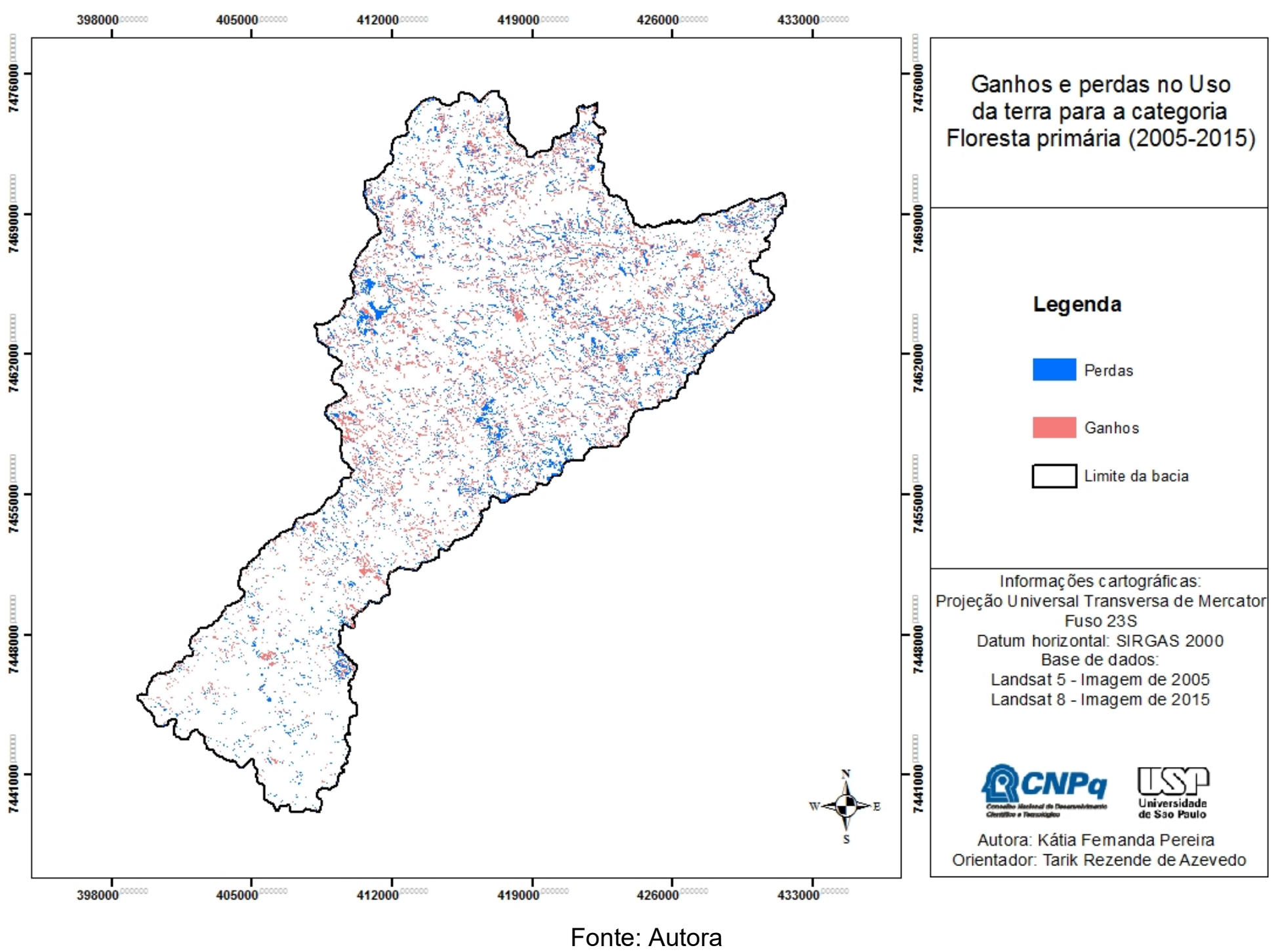


Quadro 5: Comparação dos mapas de ganhos e perdas na área da bacia para a categoria Floresta primária

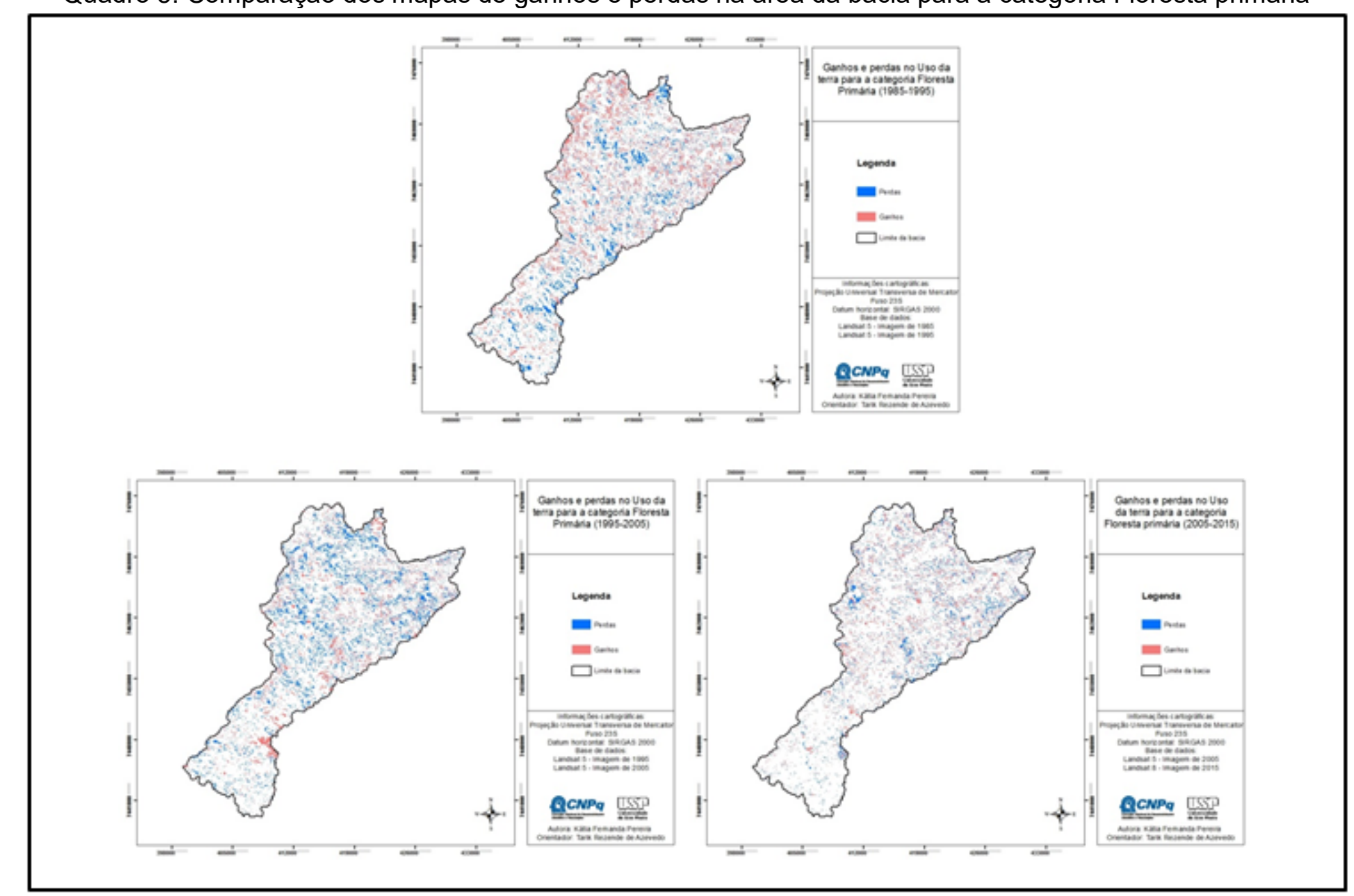

Fonte: Autora 


\subsubsection{Ganhos e perdas da terra para a categoria Vegetação secundária}

Na categoria vegetação secundária classificamos as vegetações rasteiras, de pequeno porte, arbustivas e áreas de várzea cobertas por vegetação.

De acordo com a resolução CONAMA n417 de 23/11/09, a vegetação secundária ou em regeneração é a "resultante dos processos naturais de sucessão, após supressão total ou parcial da vegetação primária por ações antrópicas ou causas naturais, podendo ocorrer espécies remanescentes da vegetação primária" (BRASIL, 2019).

Geralmente são áreas onde ocorreram queimadas e cortes rasos, para o benefício da agricultura e estabelecimento de pastagens.

Nos anos entre 1985 e 1995, a categoria de vegetação secundária perdeu parte de sua área para as classes de floresta primária, pastagem, reflorestamento e área construída. A categoria só demonstrou ganhos na categoria água, como visto no gráfico seguinte:

Gráfico 18: Ganhos_e perdas de terra na categoria Vegetação secundária (1985-1995)

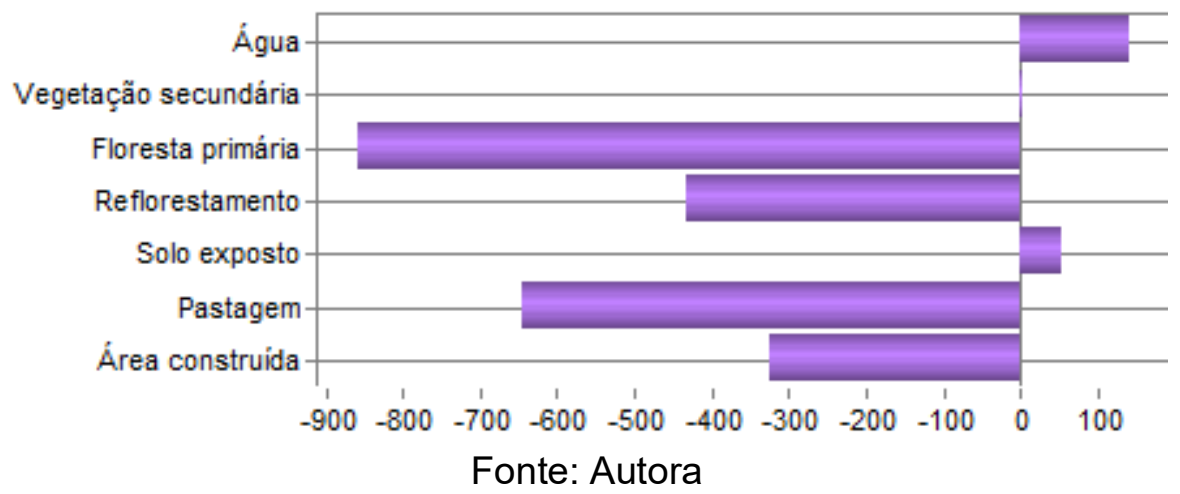

Espacializamos as perdas e ganhos da terra, na figura a seguir (figura 53): 
Figura 53: Mapa de ganho e perda na categoria Vegetação secundária (1985-1995)

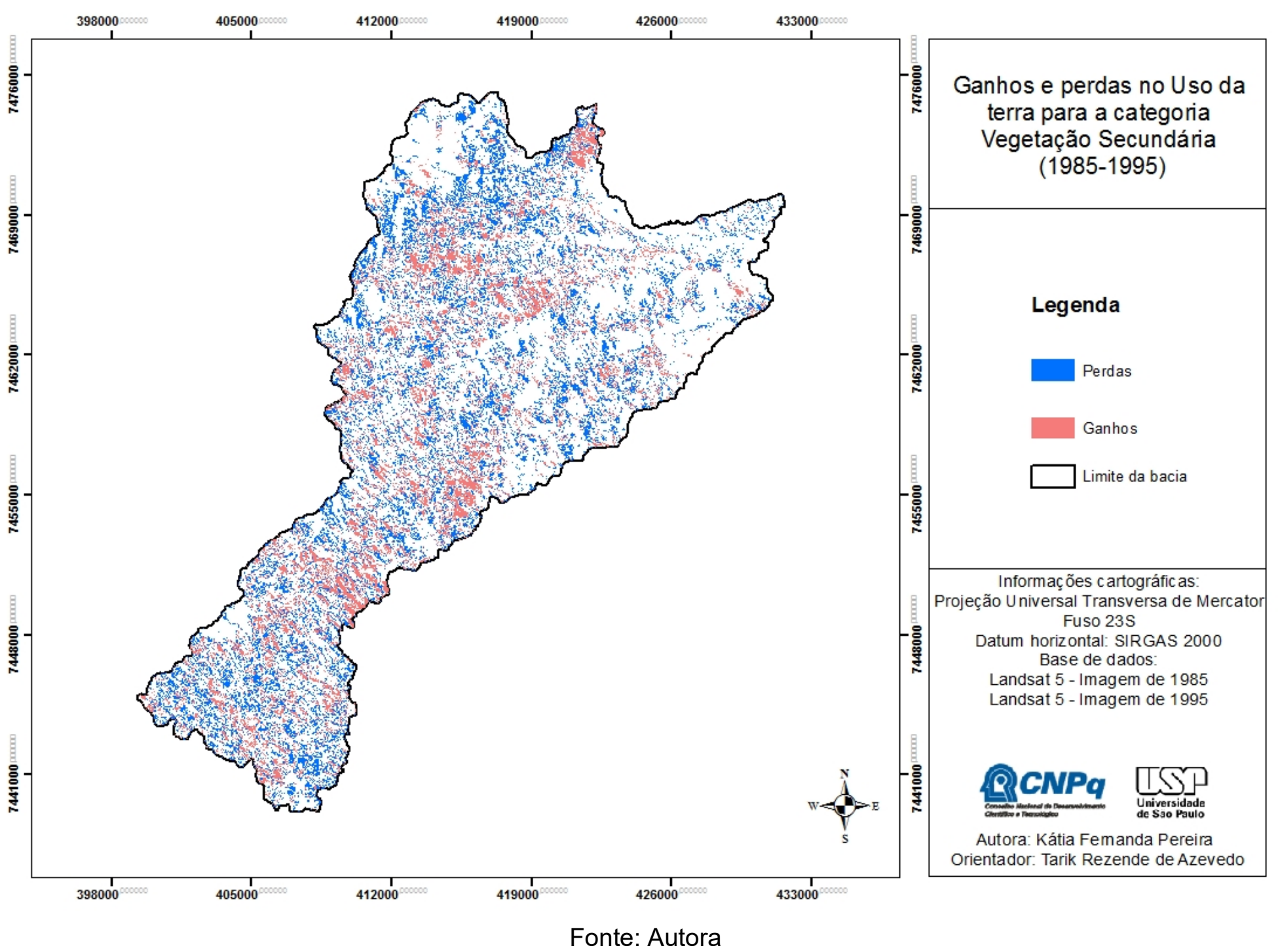


Entre os anos de 1995 e 2005, observamos que em 10 anos, a situação inverteu-se. Neste período houve ganhos, principalmente, sobre as categorias floresta primária, pastagem e área construída. Considerar um crescimento da vegetação secundária sobre a floresta primária, é ter ciência de que a paisagem campestre emergiu em detrimento da floresta. Geralmente, algumas destas áreas de vegetação secundária são recomposições Em muitas situações, essas áreas de cobertura campestre refletem a recomposição da floresta nativa em crescimento ou podem ser áreas antes voltadas a recuperação vegetal, atualmente abandonadas.

Gráfico 19: Ganhos e perdas de terra na categoria Vegetação secundária (1995-2005)

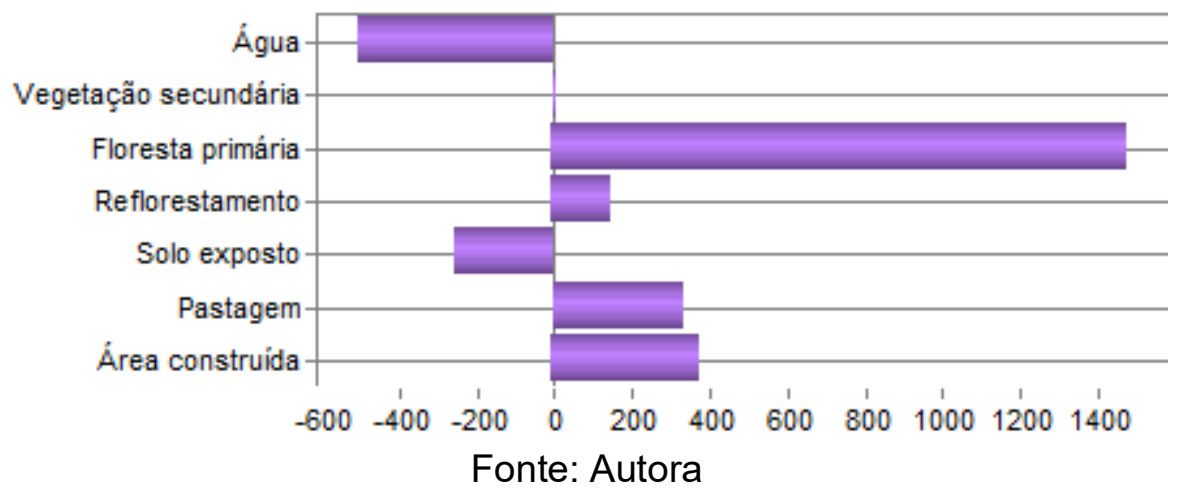

Espacializamos as perdas e ganhos da terra, na figura 54 : 
Figura 54: Mapa de ganho e perda na categoria Vegetação secundária (1995-2005)

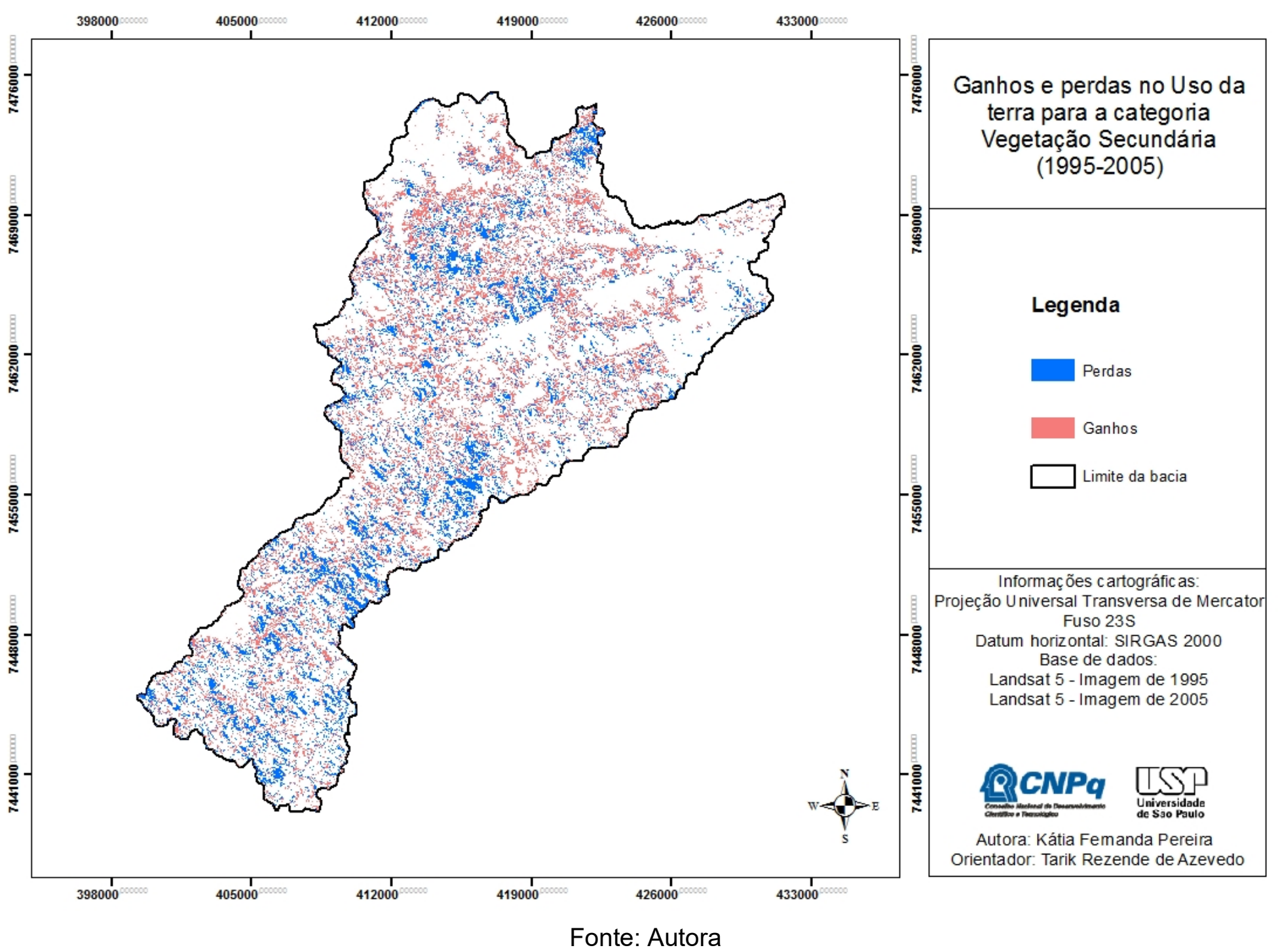


Para os anos entre 2005 e 2015, nota-se que a categoria só cresceu expressivamente sobre a pastagem, além de áreas menores como água, solo exposto e área construída. Somam-se as áreas de perda para as categorias floresta primária e reflorestamento.

Ao analisar o ganho da categoria vegetação secundária sobre o uso pastagem e área construída temos um panorama positivo, pois a regeneração da vegetação é preponderante para o estabelecimento de um ambiente sustentável, direcionado à recomposição da floresta primária.

Gráfico 20: Ganhos e perdas de terra na categoria Vegetação secundária (2005-2015)

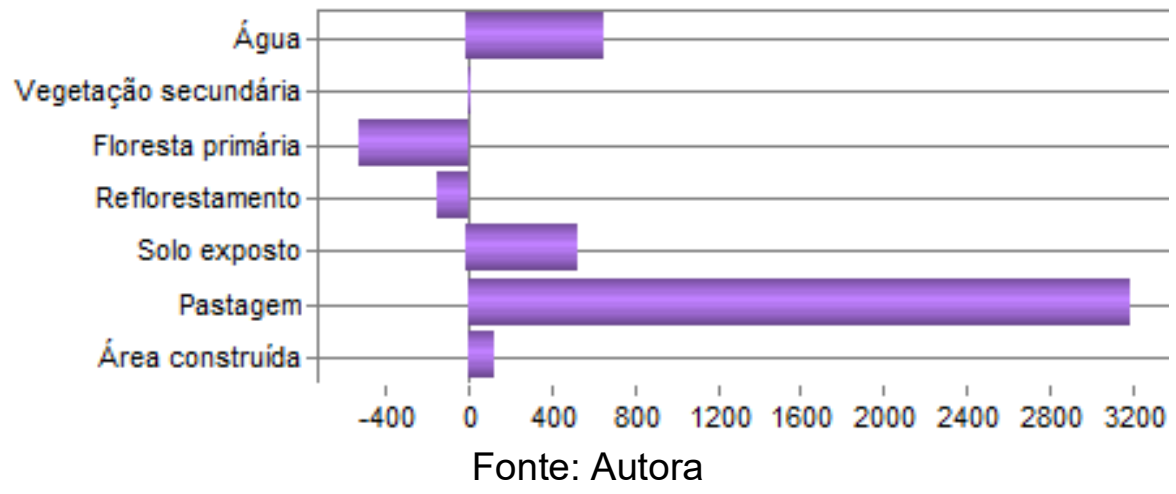

Espacializamos as perdas e ganhos da terra, na figura a seguir (figura 55) e o quadro comparativo neste período (quadro 6): 
Figura 55: Mapa de ganho e perda na categoria Vegetação secundária (2005-2015)

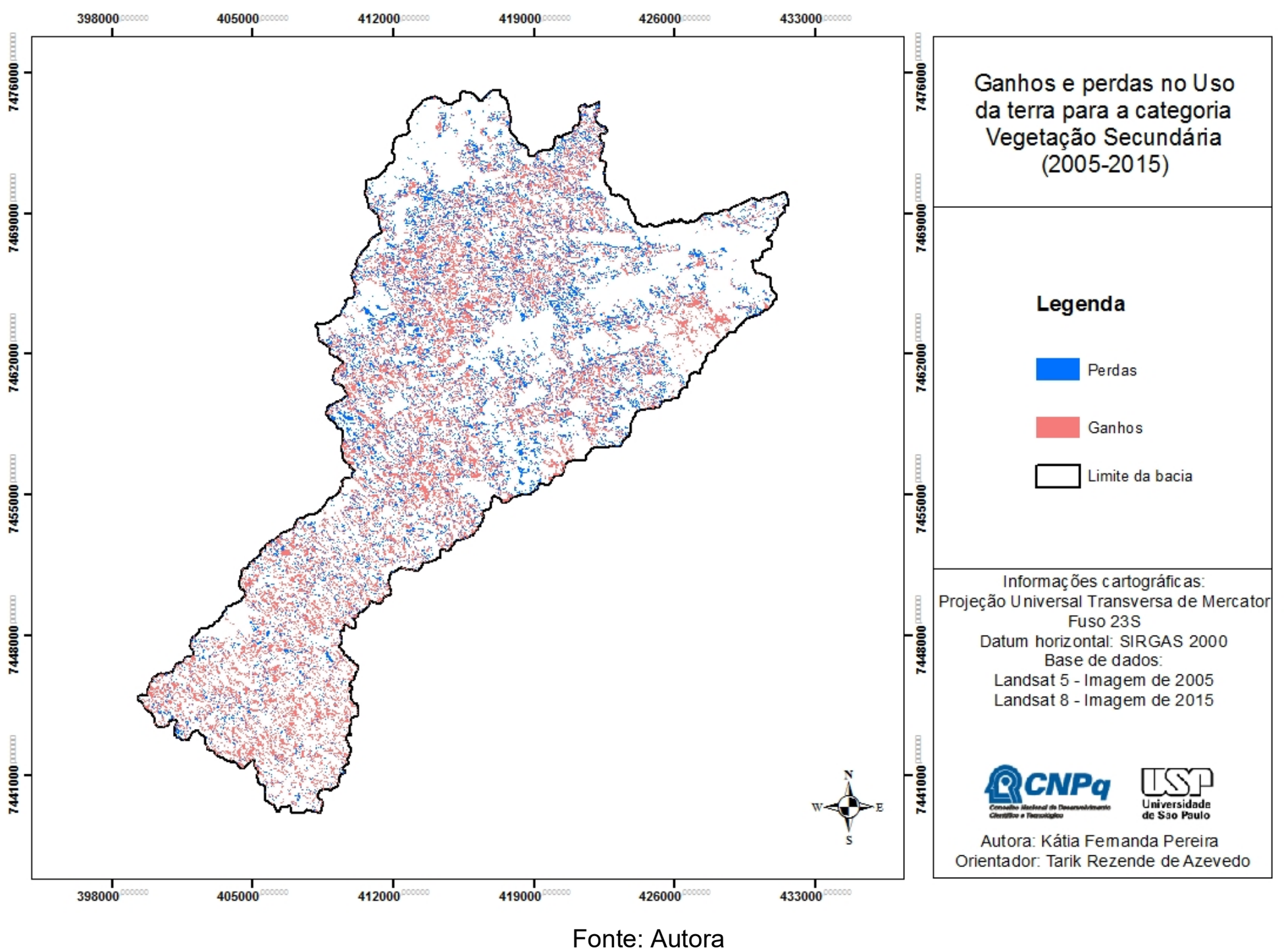


Quadro 6: Comparação dos mapas de ganhos e perdas na área da bacia para a categoria Vegetação secundária

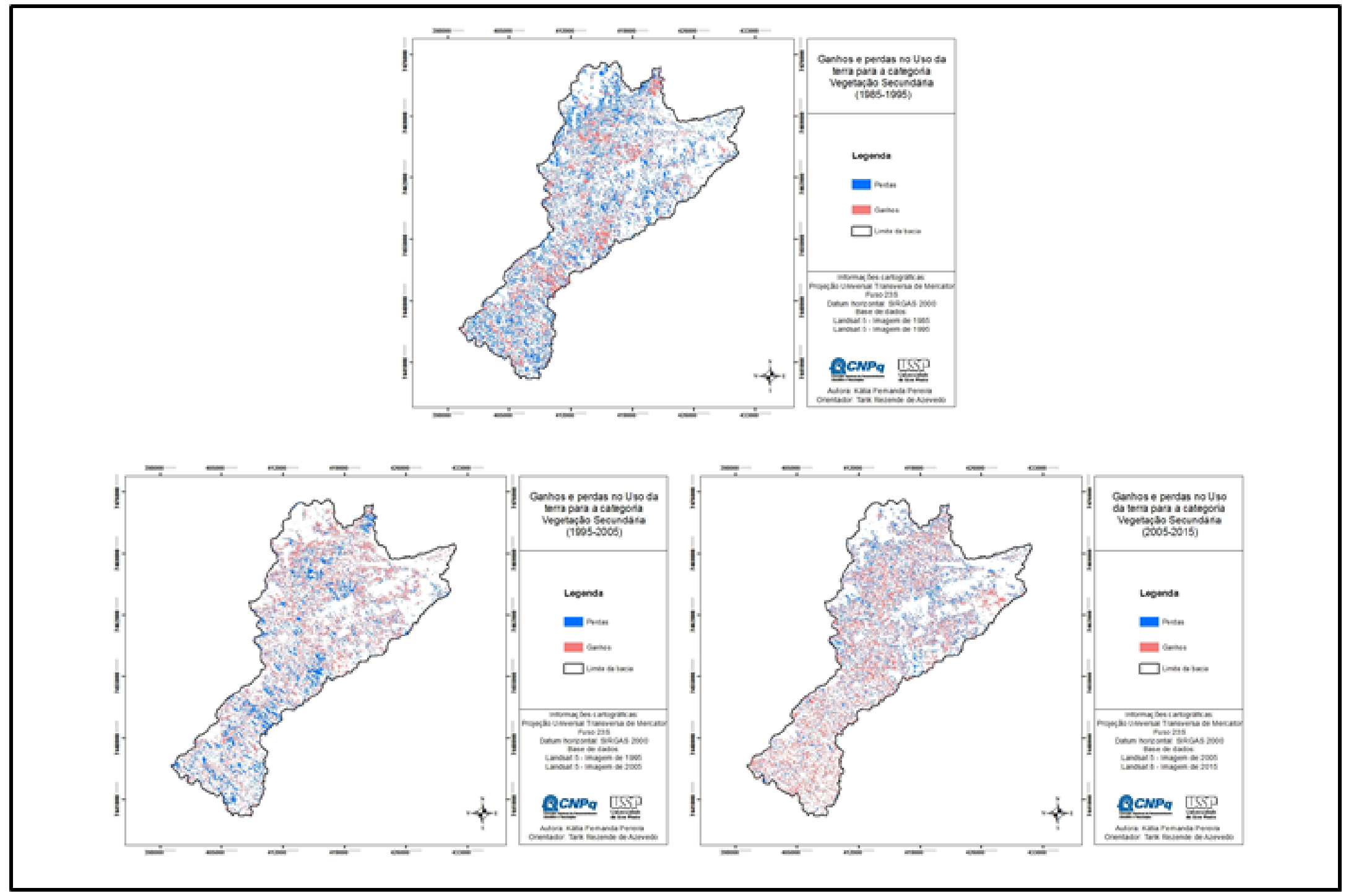

Fonte: Autora 


\subsubsection{Ganhos e perdas da terra para a categoria Água}

A categoria água englobou os cursos d'água identificáveis na imagem de satélite, e as áreas de represamentos ou pequenos reservatórios na bacia.

A classe, entre os anos de 1985 e 1995 perdeu parte de sua área para todas as classes. A floresta primária contida que foi sobreposta neste período pode se referir ao replantio da mata ciliar, onde a copa das árvores impossibilitou a visão dos corpos d'água, considerando a resposta espectral da imagem de satélite. Os ganhos de pastagem sobre a categoria água podem ter ocorrido pelo represamento de águas rasas ou que posteriormente foram assoreadas.

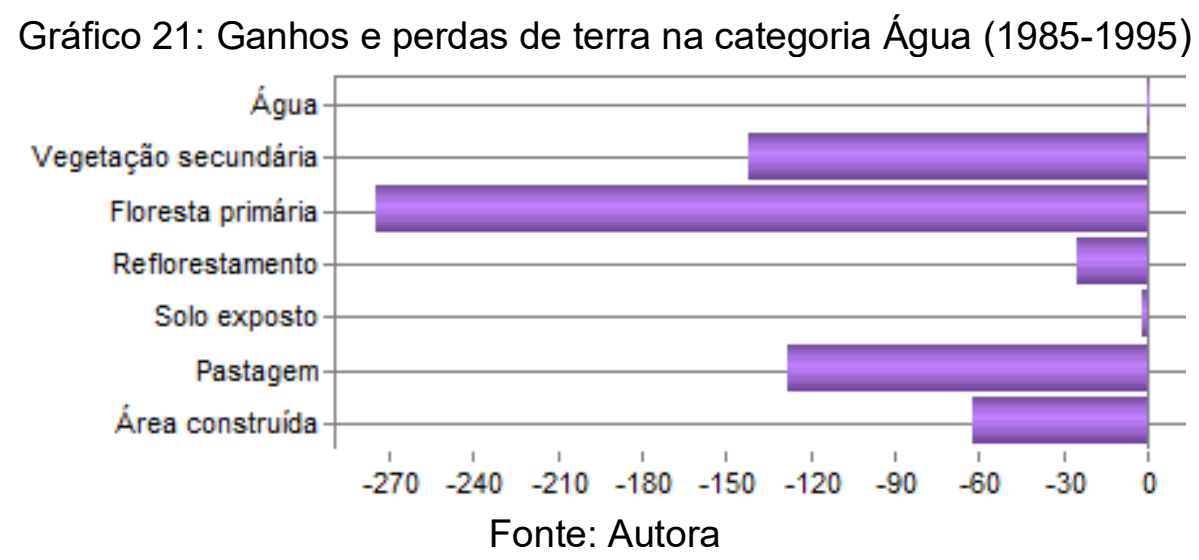

As transformações ocorridas nesse período estão registradas na figura 56, a qual espacializa as áreas onde ocorreram perda e ganho relacionadas à categoria. 
Figura 56: Mapa de ganho e perda na categoria Água (1985-1995)

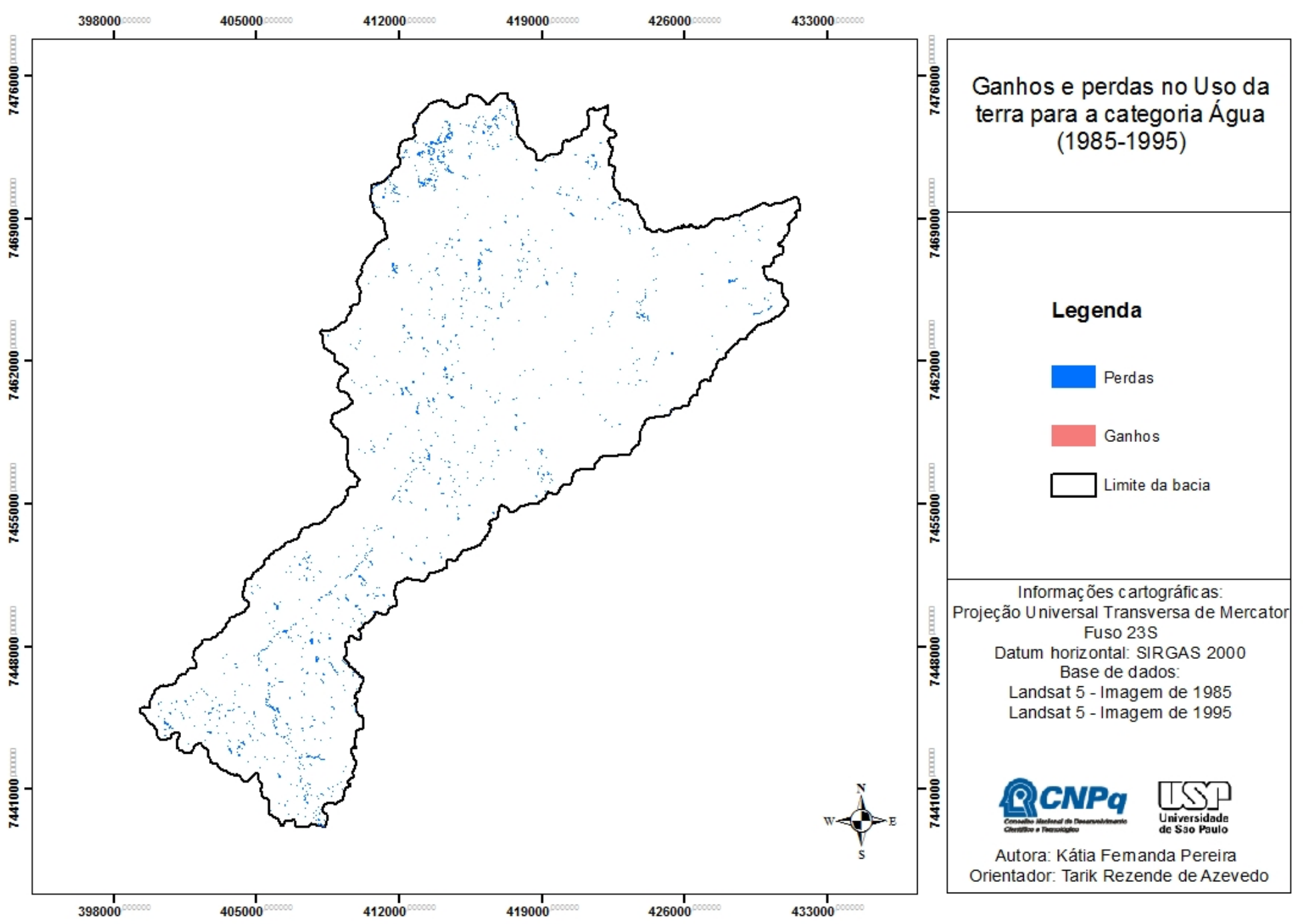

Fonte: Autora 
Entre os anos de 1995 e 2005, esta categoria de uso voltou a apresentar aumento. Parte deste aumento deve-se a formação de áreas de lagoas e represas destinadas para dessedentação de animais e fontes de água para irrigações.

Na visualização das imagens de satélite, contabilizamos novas áreas surgidas como manchas, consideradas áreas úmidas. Estas áreas também aumentam quando há a retirada da vegetação nativa, com o nível do lençol freático se elevando.

Gráfico 22: Ganhos e perdas de terra na categoria Água (1995-2005)

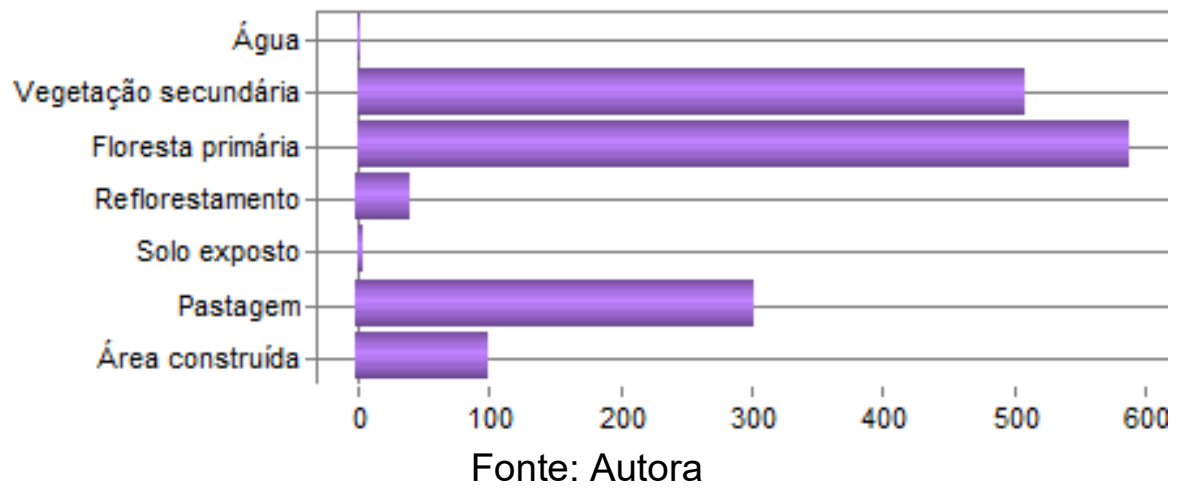

Espacializamos as perdas e ganhos da terra, na figura $57:$ : 
Figura 57: Mapa de ganho e perda na categoria Água (1995-2005)

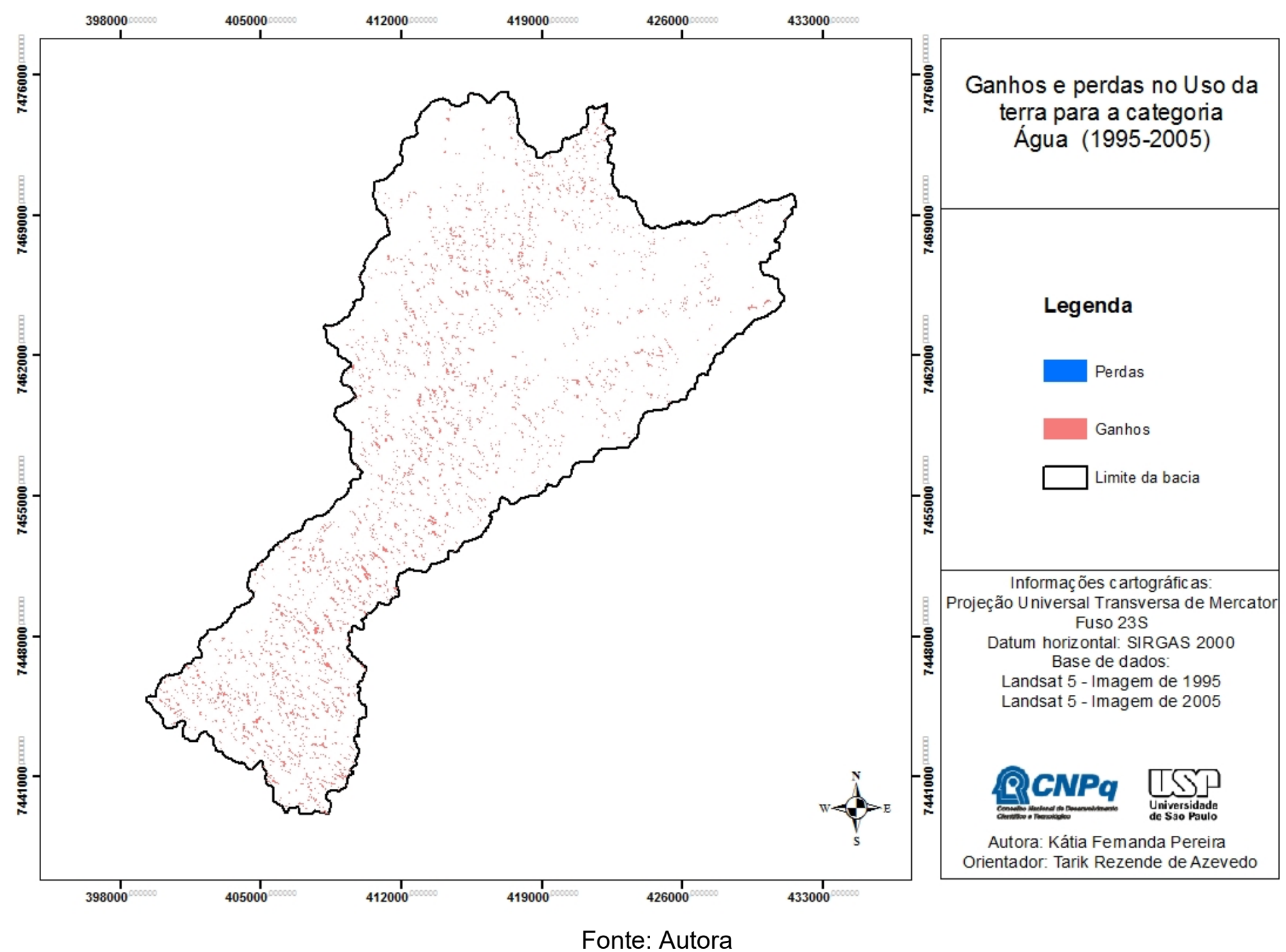


Por fim, analisamos os dados para os anos entre 2005 e 2015 e observa-se que houve um pequeno ganho da categoria água sobre a categoria solo exposto.. Constata-se, ainda, que a substituição da água pela floresta primária e vegetação secundária, é compatível com a conservação das áreas de preservação permanente. Mesmo que o aumento do reflorestamento sobre a categoria água tenha sido pequeno, esta é uma questão importante, uma vez que as espécies mais utilizadas no reflorestamento são incompatíveis com as áreas próximas à cursos d’água.

Gráfico 23: Ganhos e perdas de terra na categoria Água (2005-2015)

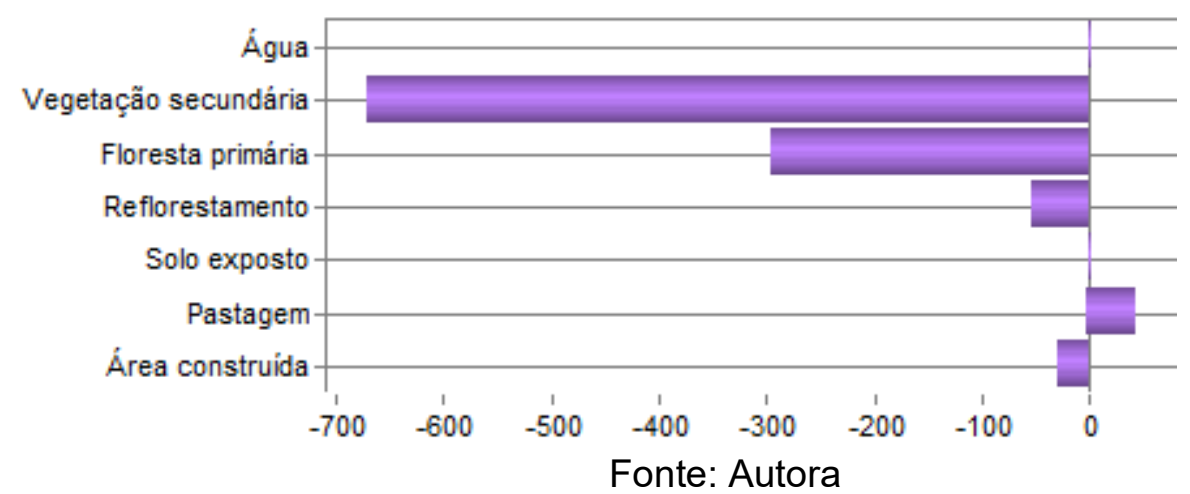

As áreas de ocupação desta categoria estão representadas na figura 58 e no quadro 7, representando a junção de todos os anos estudados. 
Figura 58: Mapa de ganho e perda na categoria Água (2005-2015)

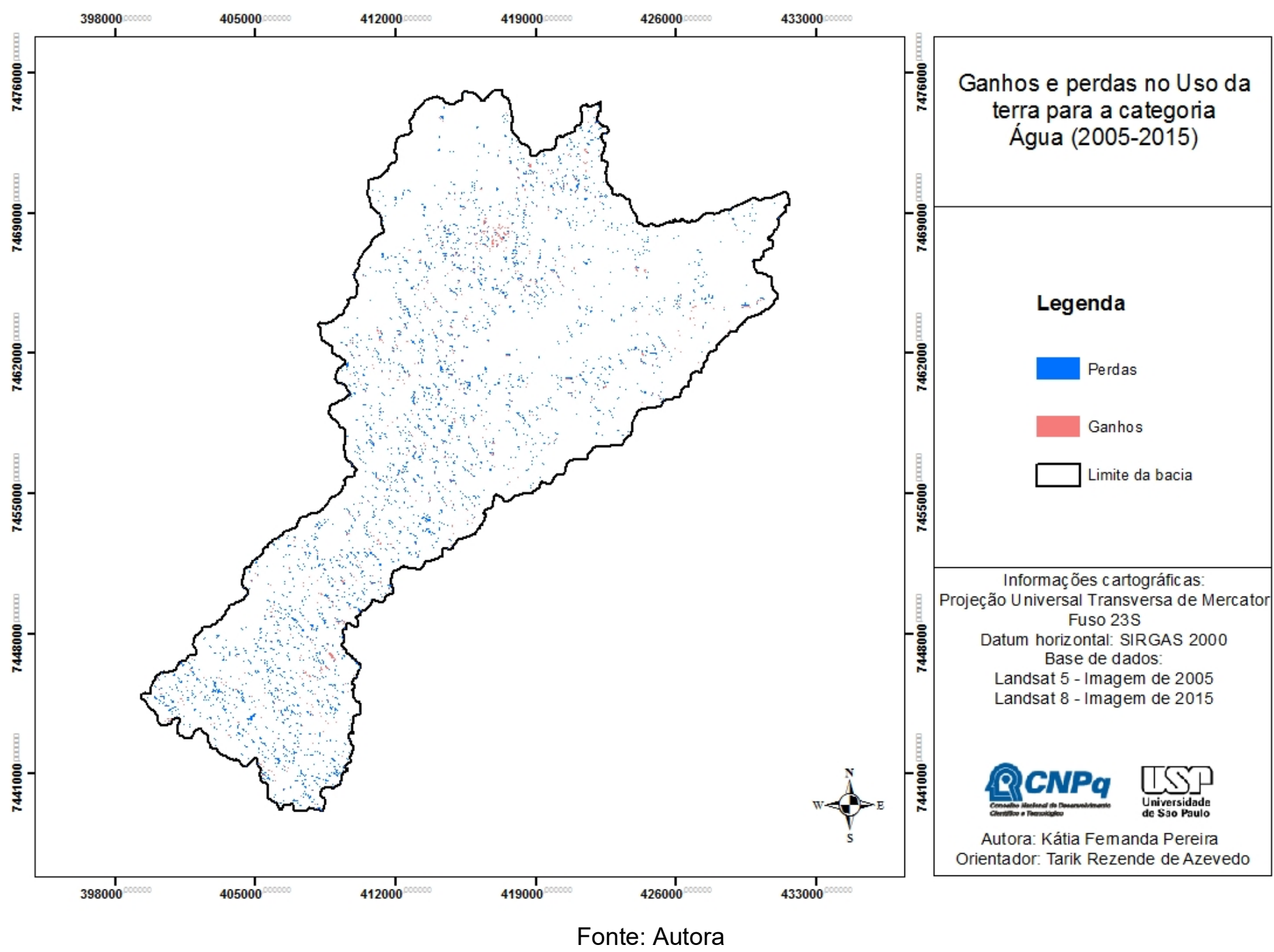


Quadro 7: Comparação dos mapas de ganhos e perdas na área da bacia para a categoria Água

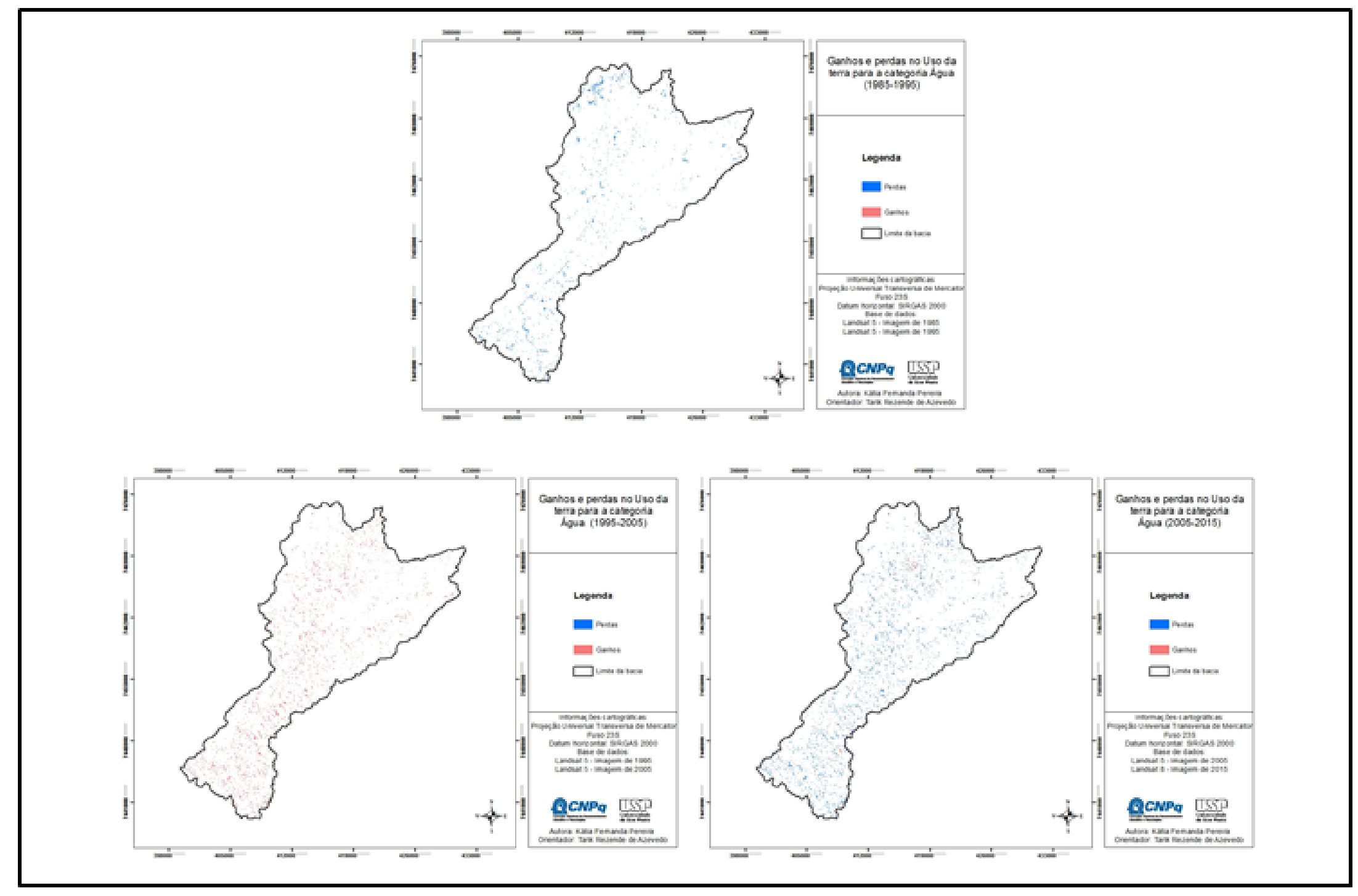

Fonte: Autora 
Como esta Bacia é uma importante fonte de abastecimento de uma região populosa e com forte apelo industrial é de extrema importância pensar em estratégias de longo prazo, para que se garanta a disponibilidade hídrica em qualidade e quantidade suficientes. Estas estratégias devem abranger desde o tratamento de esgoto para que a água retorne limpa aos rios e córregos e siga seu ciclo natural, como também a preservação da cobertura vegetal e a fiscalização do uso adequado do solo, afinal, esta região já é naturalmente propensa a ocorrência de escorregamentos, erosão, solapamento de margens de rios e inundações.

\subsection{Principais mudanças no Uso da terra entre 1985 e 2015}

De acordo com os próximos gráficos, sintetizamos as mudanças ocorridas na bacia entre os 30 anos correntes.

Para os anos entre 1985 e 1995 (gráfico 24), constatamos que as categorias que avançaram foram floresta primária, reflorestamento e área construída e as categorias que tiveram um decréscimo foram água, vegetação secundária, solo exposto e pastagem.

Gráfico 24: Mudanças no uso da terra entre 1985 e 1995 (em ha)

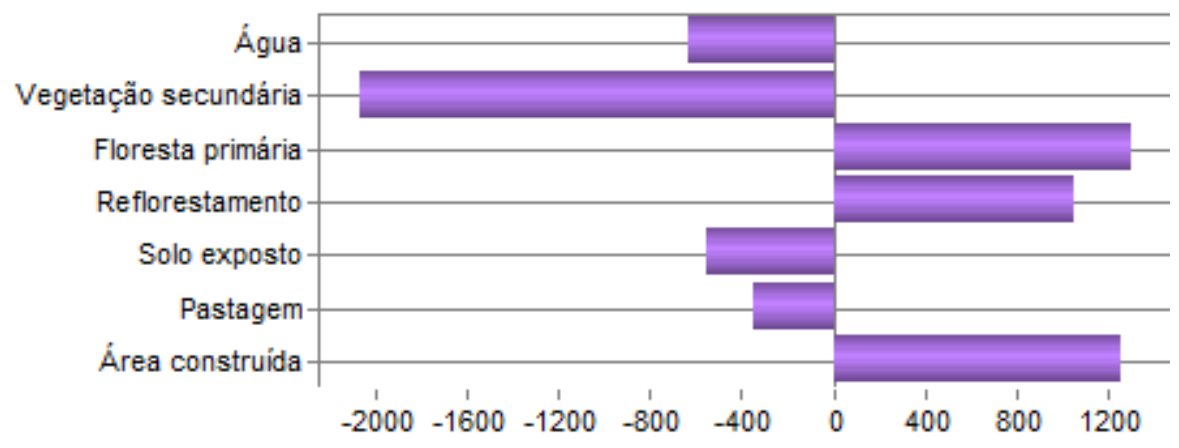

Fonte: Autora 
Entre os anos entre 1995 e 2005, observamos que as classes de uso da terra que se ampliaram foram água, vegetação secundária e solo exposto. Já as que diminuíram foram floresta primária, reflorestamento, pastagem e área construída, como observamos no gráfico 25.

Gráfico 25: Mudanças no uso da terra entre 1995 e 2005 (em ha)

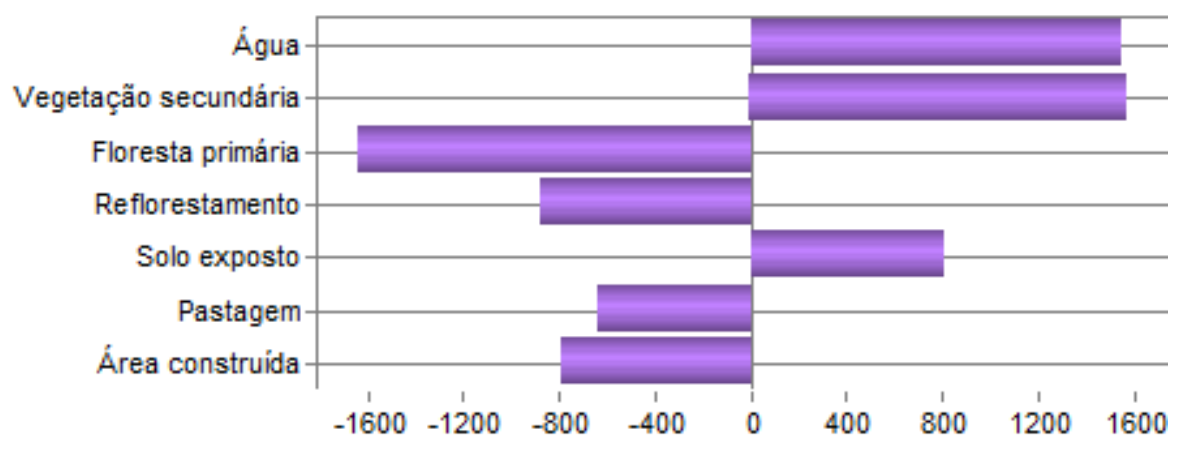

Fonte: Autora

Para os anos entre 1985 e 1995, concluímos que as classes de vegetação secundária, floresta primária, reflorestamento e área construída obtiveram aumento. Por fim, as categorias água, solo exposto e pastagem apresentaram retrocesso. (gráfico 26)

Gráfico 26: Mudanças no uso da terra entre 2005 e 2015 (em ha)

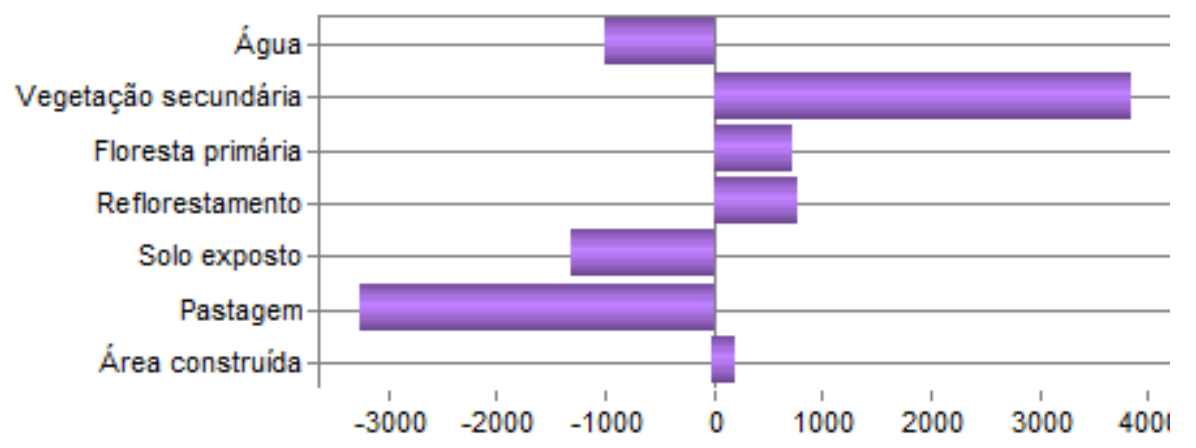

Fonte: Autora 
Para obter um panorama geral da bacia neste intervalo de tempo estudado, elaboramos um mapa das principais transições ocorridas, onde é possível averiguar o qualidade ambiental da bacia frente às mudanças ocorridas.

Utilizamos a ferramenta Map Changes do software Idrisi, a qual sintetiza as maiores transições entre os anos estudados.

A carta, configurada nas cores verde, amarelo e vermelho, ilustra o estado ambiental da bacia, como um verdadeiro "semáforo ambiental", (BLOWERS, 1993) como destaca a figura 59: 
Figura 59: Mapa de mudanças do uso da terra na área da bacia entre 1985 e 2015

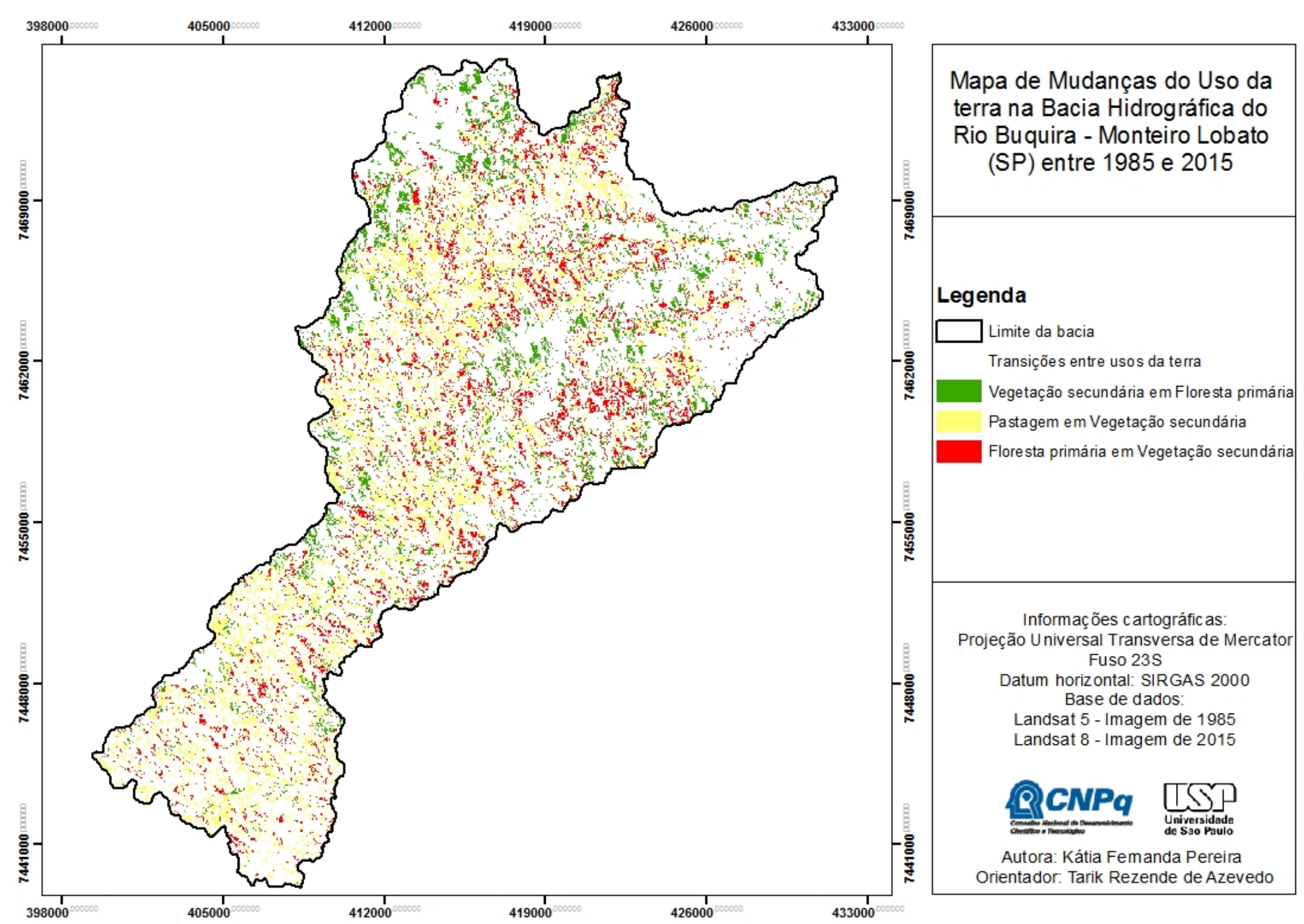

Fonte: Autora 
Nas transformações ocorridas, em menor parte do território, visualizamos a transição de floresta primária para vegetação secundária. Desta forma, as mudanças ocorreram de forma negativa, devido à supressão da mata nativa. Em maior parte, o uso da terra que mais houve ocorrência foi entre vegetação secundária para floresta primária e entre pastagem para vegetação secundária. Desta forma, observamos mudanças positivas entre estes 30 anos.

Como a classificação das imagens é feita através das imagens Landsat com a resolução de 30 metros, considera-se que pequenas áreas podem não ter sido identificadas, assim como um pequeno retrocesso ou aumento das áreas podem representar grandes mudanças temporais, sendo que cada pixel da imagem representa uma área no terreno de 0,09 ha (INPE, 2017).

No período estudado, a categoria vegetação secundária foi a mais dinâmica, principalmente por renovar-se em pouco espaço de tempo. Esta categoria esteve em redução, ao perder áreas para a categoria florestal, representando, dentre outras razões, que a área pode ter sido instituída como reserva legal, o que promoveria o crescimento de sua revegetação natural.

Quando a classe vegetação secundária ganhou áreas sobre a categoria pastagem, atribuímos este fato, principalmente, à diminuição da pecuária no local, promovendo o crescimento natural da vegetação ou ao cumprimento da legislação ambiental por parte dos proprietários de terras, onde foi estimulado o replantio de espécies naturais.

É possível observar no gráfico a seguir (gráfico 27) que a que a bacia hidrográfica possui um bom estado ambiental, pois apresentou ganhos em floresta primária, em vegetação secundária, em área construída e diminuição nas categorias 
solo exposto e pastagem. Com o reflorestamento não predatório na região, consideramos os ganhos em reflorestamento como positivo.

Gráfico 27: Mudanças no uso da terra entre 1985 e 1995 (em ha)

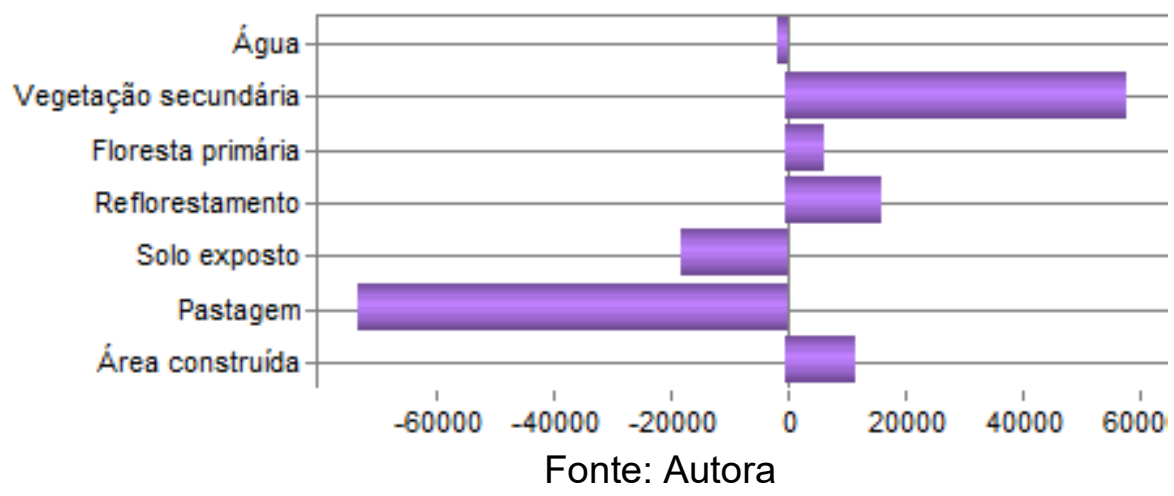

A categoria água não, necessariamente, diminuiu, pois a identificação dos elementos na imagem variam substancialmente entre os períodos de cheias e estiagem. Outros fatores importantes é que as imagens apresentam qualidades distintas e a apresentação de pequenos cursos d'água em relação à seu volume, muitas vezes não foram representativos para a categoria, devido à pequena quantidade de pixels detectados.

\subsection{Suscetibilidade, riscos e alagamentos $x$ Predição de mudanças para a área da bacia}

Para traçarmos um cenário futuro de mudanças na área da bacia, foi necessário elucidar se os alagamentos recorrentes na área da bacia, bem como a presença de ocupação irregular em áreas de risco seriam fatores determinantes nesta transição. 
Como os alagamentos são constantes em certos pontos da bacia, averiguamos se isto seria proveniente de causa natural ou se alguma erosão à montante estaria ocasionando esta situação.

Tal fato é de extrema importância, pois o risco sempre envolve o fator "humano", o que poderia interferir numa reordenação do uso da terra.

A imagem a seguir (figura 60), apresenta duas áreas cruciais de alagamento na bacia, permeadas de áreas residenciais:

Figura 60: Construções irregulares em áreas de APP's

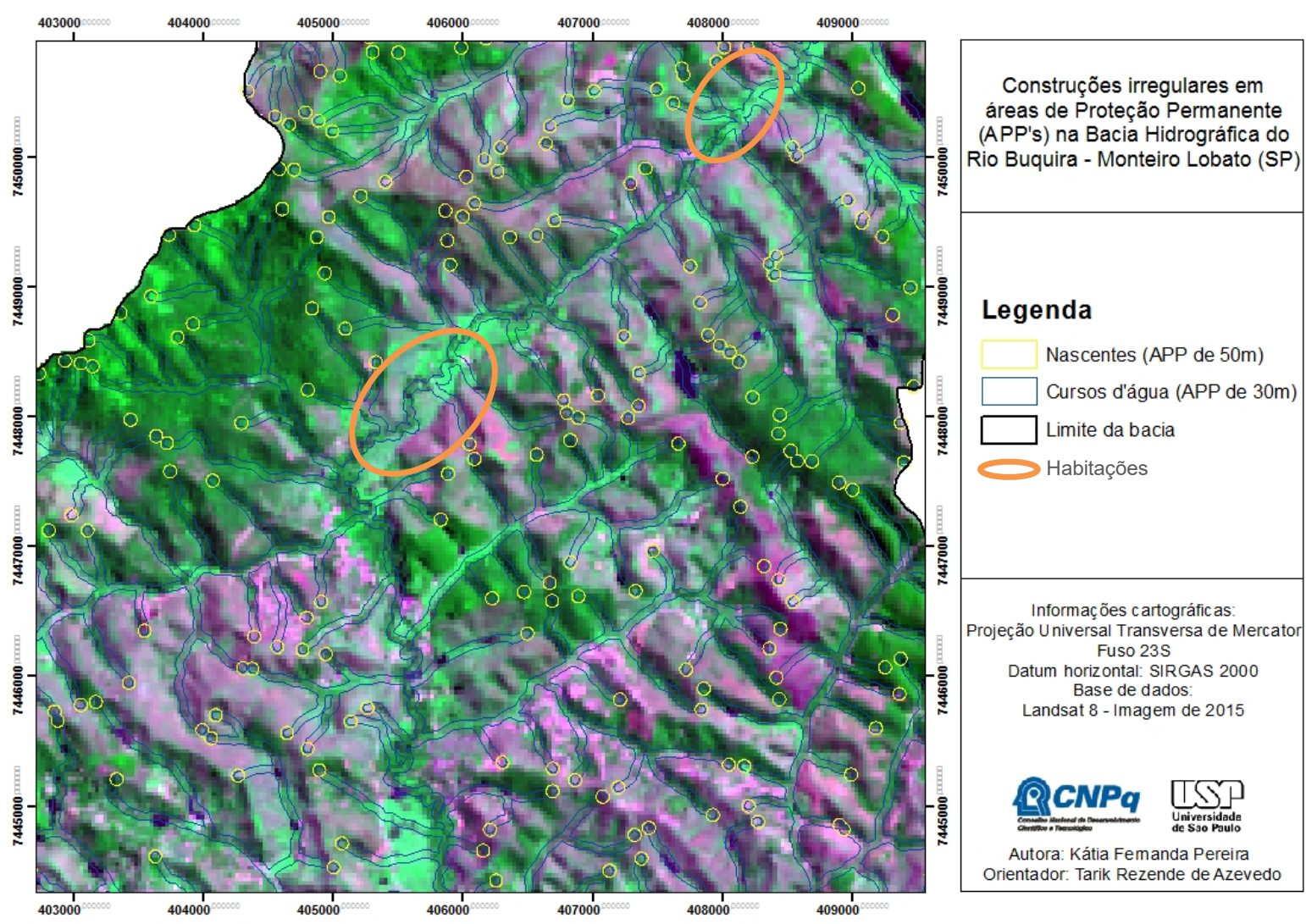

Fonte: Autora 
Delimitamos as áreas de APP com um buffer de 30 metros para cursos d'água de até 10 metros de largura, e 50 metros para as áreas de nascentes, e sumariamente detectamos a presença de área construída nestas áreas de proteção permanente.

As áreas em questão são inseridas em planícies aluvionares, o que já inviabiliza a urbanização. Estas são, em parte, intituladas como Zona de domínio de curso d'água, pela lei de zoneamento municipal e Áreas de Proteção Ambiental, de acordo com a Lei Federal 12.651, art. $4^{\circ}$.

Em consonância com as cartas de uso e cobertura da terra inferimos que a morfologia original se modificou com o passar do tempo. Hoje, as áreas de várzea deram lugar a áreas urbanizadas, onde naturalmente deveriam ser áreas de inundação e, ainda, as áreas antes cobertas com floresta primária, dão lugar a pastagens. Este cenário antropomorfizado remete ao uso inadequado da terra, acarretando danos à própria população.

Há uma porcentagem expressiva da população que ocupa as áreas de app's, e o risco ainda é maior por também se configurarem como área de domínio de curso d'água, o que já nos indica que esta região sofre com alagamentos em virtude do escoamento superficial. Estas áreas são naturalmente sujeitas à inundação, e também foram designadas como Áreas de Controle à Impermeabilização, segundo a Lei Complementar 306/06, possuindo restrições urbano-ambientais que objetivam a recarga dos aquíferos, o que previne inundações nas áreas urbanas.

Para analisarmos a ocorrência dos alagamentos, houve a necessidade em recorrermos às cartas clinográficas da bacia, pois as declividades mais acentuadas influenciam diretamente no comportamento das precipitações. Quanto maior a 
declividade, maior a velocidade da água e menor a capacidade de infiltração do solo, ocasionando possíveis acumulações de água na vazante.

As cartas de uso e cobertura da terra, principalmente no que tange a cobertura vegetal, são de fundamental importância, pois esta controla o escoamento superficial por meio das infiltrações, atenuando a força da água diretamente no solo - reduzindo, assim, a probabilidade de inundações.

De maneira específica, pode-se considerar que os alagamentos também estão bastante relacionados às características da pedologia, geologia, e morfologia da bacia hidrográfica. Nesta perspectiva, elaboramos a Carta de Suscetibilidade à erosão, onde unimos as características pedológicas, clinográficas e de uso e uso e cobertura da terra, a determinarmos as áreas mais propensas à erosão (segundo Crepani, 2001), e consequentemente, analisar se estas áreas culminaram com os pontos erosivos observados em campo.

A construção da carta de susceptibilidade à erosão, tem como base a análise multicriterial ponderada em ArcGis, eficiente para a análise da morfodinâmica da paisagem, através da sobreposição e interpretação das informações através de álgebra de mapas. É um importante instrumento para a manipulação de diversos dados e variáveis, onde pretende-se depurar, entre eles, quais colaboram para a ocorrência de um determinado processo e em quanto contribuem. Desta forma, os distintos fatores que influenciam o processo são sintetizados através do cruzamento ordenado por pesos previamente definidos. Utilizamos a metodologia de Crepani (2001) a definir a ponderação das categorias.

A partir da ferramenta Weighted Overlay, no ArcGis, foi possível ponderar cada carta utilizada, bem como suas variáveis, observadas no quadro 8 : 
Quadro 8: Ponderação para as classes de Susceptibilidade dos solos à erosão

\begin{tabular}{cc}
\hline Cartas físicas & Pesos \\
\hline Carta de Pedologia & $40 \%$ \\
\hline Cambissolo & 7 \\
\hline Latossolo & 6 \\
Gleissolo & 5 \\
Argissolo & 4 \\
Neossolo & 8 \\
\hline Carta de Declividade & $30 \%$ \\
(\%) & 1 \\
\hline $0-5$ & 3 \\
\hline $5-12$ & 5 \\
\hline $12-30$ & 7 \\
30-47 & 9 \\
\hline >47 & $30 \%$ \\
\hline Carta de Uso e & \\
\hline cobertura da terra & 8 \\
\hline Área construída & 8 \\
\hline Pastagem & 7 \\
\hline Solo Exposto & 9 \\
\hline Reflorestamento & 4 \\
\hline Floresta primária & 2 \\
\hline Vegetação & 3 \\
secundária & \\
\hline Água & 1 \\
\hline
\end{tabular}

Fonte: Adaptado de Crepani, 2001

Onde, a porcentagem referente a cada carta e os valores de 1-9, quanto aos atributos do meio físico, se assimilam ao grau de importância que estas apresentaram para a suscetibilidade à erosão na bacia (figura 61). 
Figura 61: Carta de Suscetibilidade à Erosão na Bacia Hidrográfica do Rio Buquira

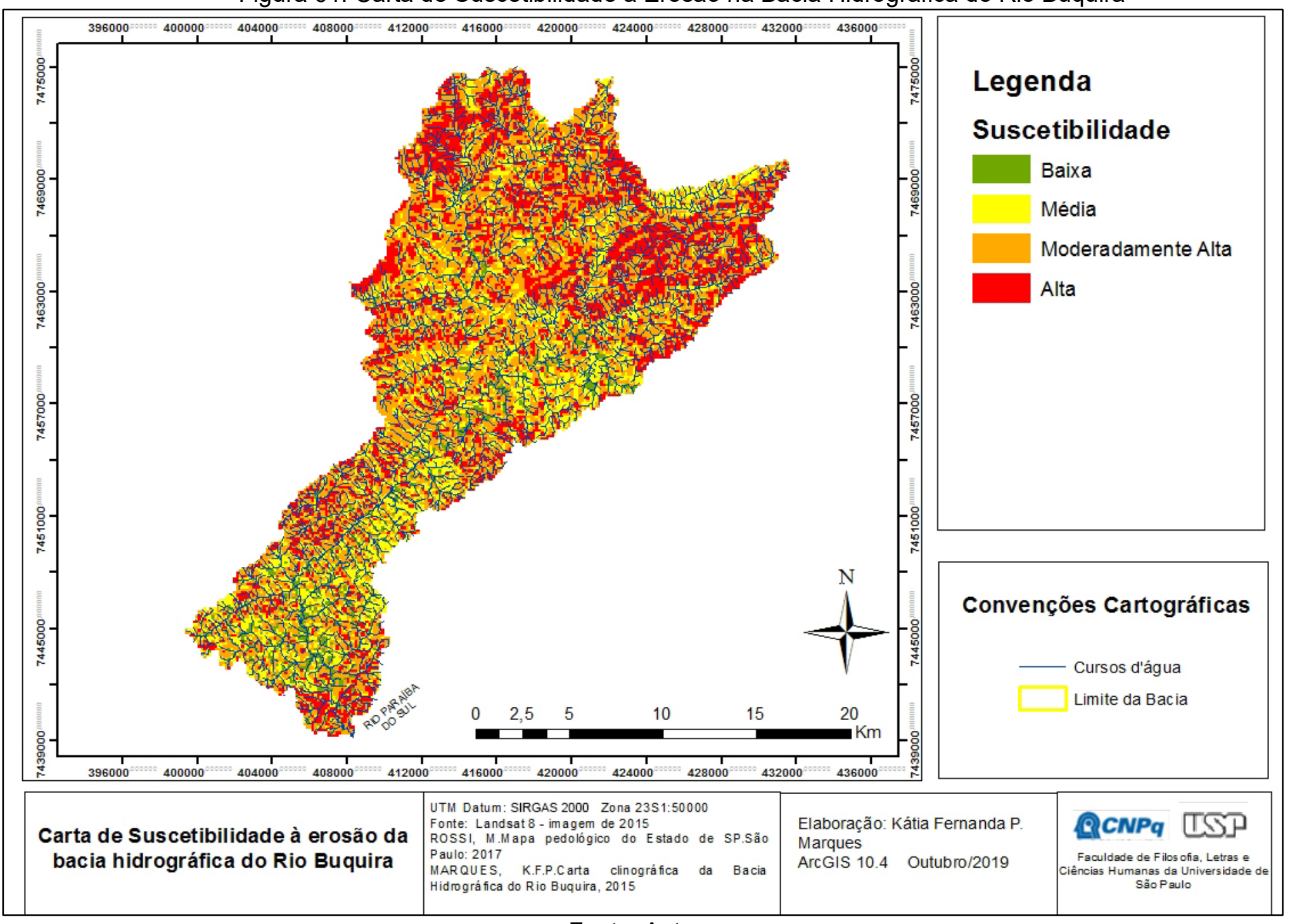

Fonte: Autora 
Observamos que a bacia possui suscetibilidade à erosão, justamente nas áreas próximas aos alagamentos, ou seja, quase no limite entre São José dos Campos e Monteiro Lobato - porção central da bacia. A alta suscetibilidade à erosão também culmina com as áreas de grandes declividades na bacia, precisamente onde pontuamos algumas áreas de risco na bacia: (figura 62)

Figura 62 - Placa em local de área de risco

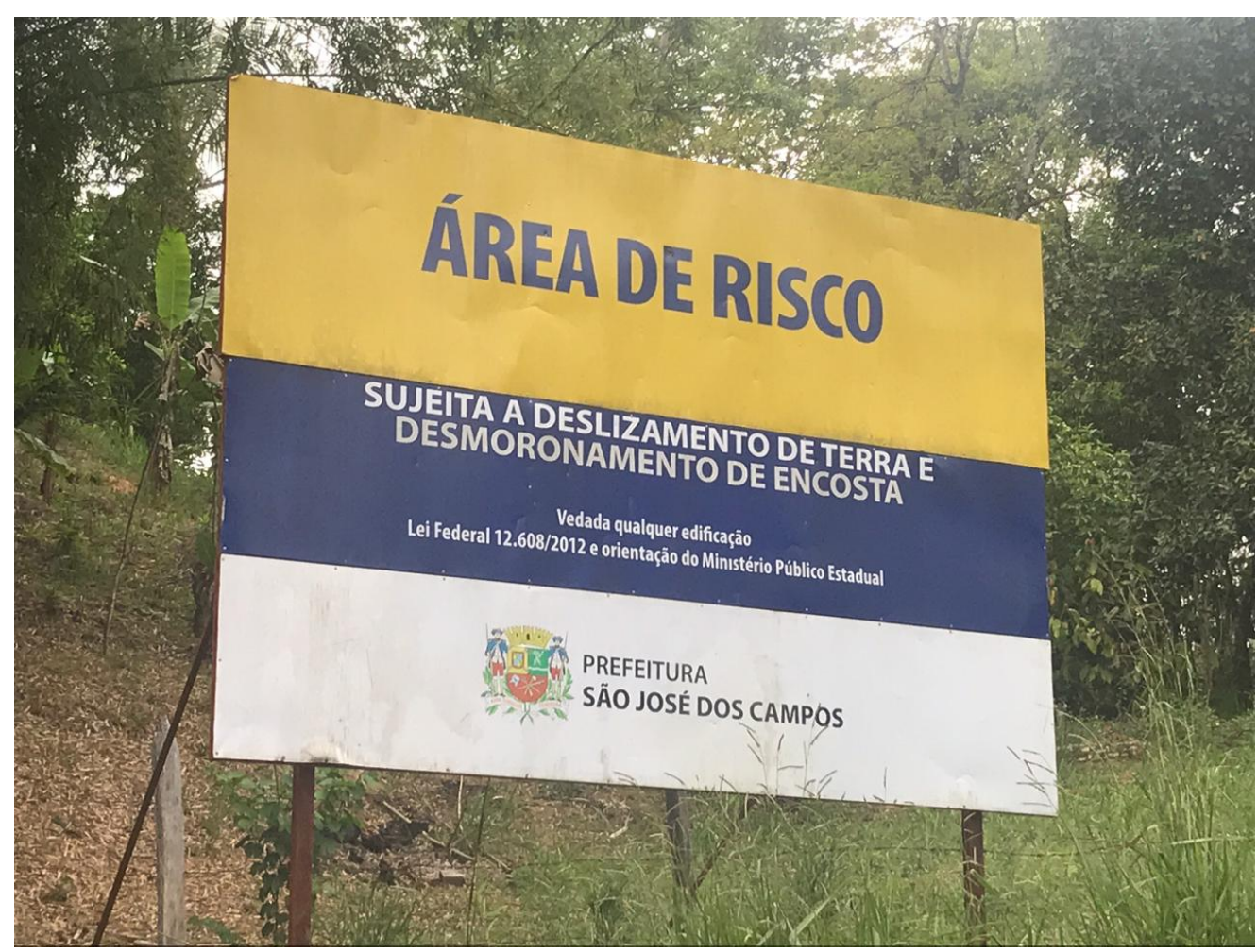

Foto: Autora

As áreas de suscetibilidade moderadamente alta coincidiram com as áreas urbanas da bacia, onde a própria ação antrópica, impermeabilização e arruamento ortogonal (famoso "tabuleiro de xadrez") contribuem para o carreamento do solo adjacente e posterior assoreamento dos canais e com as áreas de cambissolos ao norte da bacia, em porções de difícil acesso devido à ocorrência da floresta primária conservada em meio às maiores declividades da bacia. 
Com a predominância da média suscetibilidade na bacia, nos deparamos com as declividades de 12 a 30\% em latossolo, onde há a maior ocorrência das pastagens.

Por fim, a baixa suscetibilidade à erosão coincide, principalmente, com as áreas de fundo de vale de declividades de $0-5 \%$, declividades de $5-12 \%$, presença de vasta vegetação secundária e ocorrência, em pequena parte, de gleissolo. Em áreas de baixa suscetibilidade à erosão, onde encontramos o argissolo, vemos como característica a ocupação, em suma, não predatória e com breve presença de cultivos, como observado em campo.

Além de analisarmos os fatores de declividade, pedologia e uso da terra para definirmos a suscetibilidade a um posterior alagamento, outro fator preponderante é a pluviosidade. O volume e a velocidade das enxurradas dependem da intensidade, da duração e da frequência das chuvas, sendo a intensidade o fator mais significativo do processo erosivo pois durante uma chuva muito forte, milhões de gotas de chuva golpeiam o solo, desprendendo as partículas que podem ser atiradas a mais de $60 \mathrm{~cm}$ de altura e a mais de 1,5 m de distância (BERTONI et al., 1993), ou seja, um terreno desprovido de cobertura vegetal ou altamente urbanizado está mais propício à degradação.

Traçando um paralelo entre os anos iniciais de nossa pesquisa e a época atual, constatamos que com tantas mudanças ocorridas na área da bacia, frente à urbanização, industrialização, implantação da agricultura mecanizada, etc., é cada vez mais complexa a manutenção saudável de um meio antropomorfizado.

Norderman e Danelon (1990) já descreviam este paradigma na bacia do Buquira, comparando-a aos grandes centros: 
Não existem indústrias sediadas na bacia propriamente dita, as atividades aí desenvolvidas são agropecuária e lazer, e a densidade demográfica é bastante baixa. Assim sendo, qualquer interferência de caráter antropogênico que eventualmente possa ser detectada na atmosfera da bacia, será possivelmente uma consequência da poluição oriunda de cidades industrializadas situadas no Vale do Paraíba e da Grande São Paulo. Em particular, os resultados aqui apresentados referem-se ao período de Julho a Novembro de 1990, quando as chuvas na região são originadas por frentes frias oriundas do sul do hemisfério, e deste modo, a composição química das águas de chuva na Bacia do Rio Buquira irá refletir essencialmente a influência de outras regiões na qualidade da atmosfera desta mesma bacia. (NORDERMAN e DANELON, 1990, p. 877)

Comparando as médias mensais de chuvas de Monteiro Lobato e São José dos Campos, estimadas a partir das isoietas mensais, observamos nas tabelas a seguir que o volume de chuvas em Monteiro Lobato é maior, principalmente em razão Monteiro Lobato apresentar maior área florestada, com maior retenção de umidade pelo solo e consequente evapotranspiração maior. Monteiro Lobato apresenta médias anuais de 1686,3 mm (gráfico 28) e São José dos Campos com 1332,8 mm (gráfico 29).

Gráfico 28: Altura média de precipitações em Monteiro Lobato (em mm)

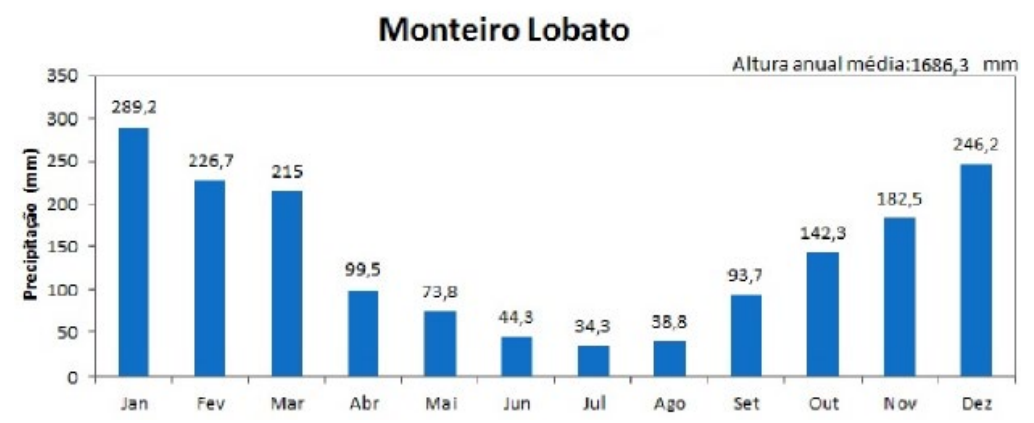

Fonte: Atlas Pluviométrico do Brasil (PINTO, et. al, 2011) 
Gráfico 29: Altura média de precipitações em São José dos Campos (em mm)

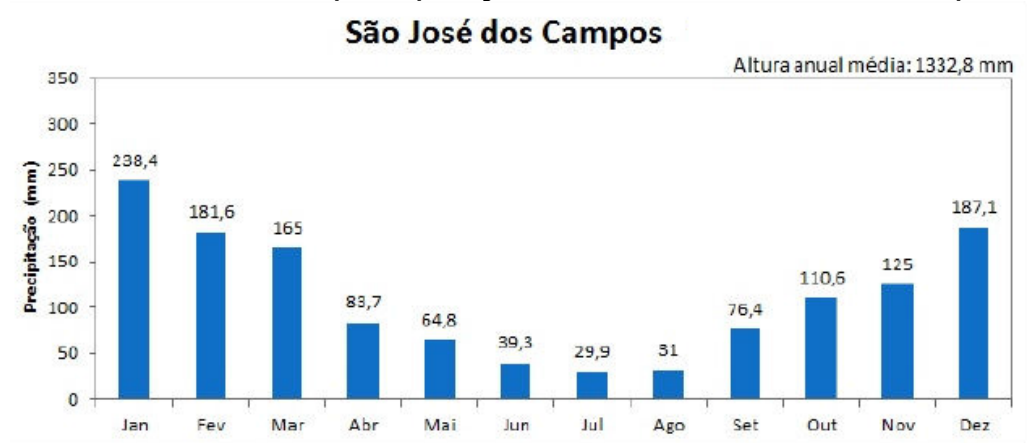

Fonte: Atlas Pluviométrico do Brasil (PINTO, et. al, 2011)

Como as ocorrências dos períodos de alagamento na área da bacia se dão em janeiro, realizamos trabalhos de campo anteriores a estes períodos, a fim de observar a ocorrência de erosões, com base nas áreas mais evidentes propostas na carta de susceptibilidade. No entanto, não consideramos nenhuma feição erosiva em potencial, próxima às calhas dos rios e à montante.

Após a ocorrência das precipitações de janeiro e o retorno à campo, observarmos a presença de assoreamento/bancos de areia em alguns pontos que antes não existiam. Desta forma, consideramos que o grande volume de chuvas em um terreno potencialmente declivoso, aumenta a velocidade da água, colaborando com a capacidade destrutiva dos escoamentos.

Assim, todo corpo hídrico tem sua área natural de inundação e esse fenômeno não é, necessariamente, sinônimo de catástrofe. Quando o homem ultrapassa os limites das condições naturais do meio em que vive as inundações passam a ser um problema social, econômico e/ou ambiental (PINHEIRO, 2007).

Após concluirmos esta etapa, estabelecemos para a bacia um cenário futuro, se forem seguidas a legislação ambiental (tanto para construções irregulares em áreas de AAP's, em áreas de risco, quanto ao plantio de mata ciliar, replantio de 
vegetação natural, dentre outros), e levando em consideração as transições dos últimos 30 anos.

Com o intuito de visualizarmos tal prognóstico da bacia, elaboramos a Carta de Predição de mudanças, com a projeção para 30 anos a partir do ano de 2015, sendo 2045 a data estipulada.

Utilizamos o modelo da "matriz de Markov", que determina a quantidade de alterações em dado momento do futuro, utilizando os mapas de uso da terra anteriores. O procedimento determina o modelo com base em uma projeção dos potenciais de transição para o futuro e cria um arquivo de probabilidades de transição, onde o arquivo de probabilidades de transição é uma matriz que registra a probabilidade de que cada categoria de cobertura terrestre mude para todas as outras categorias (IDRISI, 2009).

O procedimento foi executado com a ferramenta Change prediction do software Idrisi.

Na figura 59, observamos o mapa de Predição de mudanças na área da bacia: 
Figura 63 Carta de predição de mudanças no Uso da terra na Bacia Hidrográfica do Rio Buquira

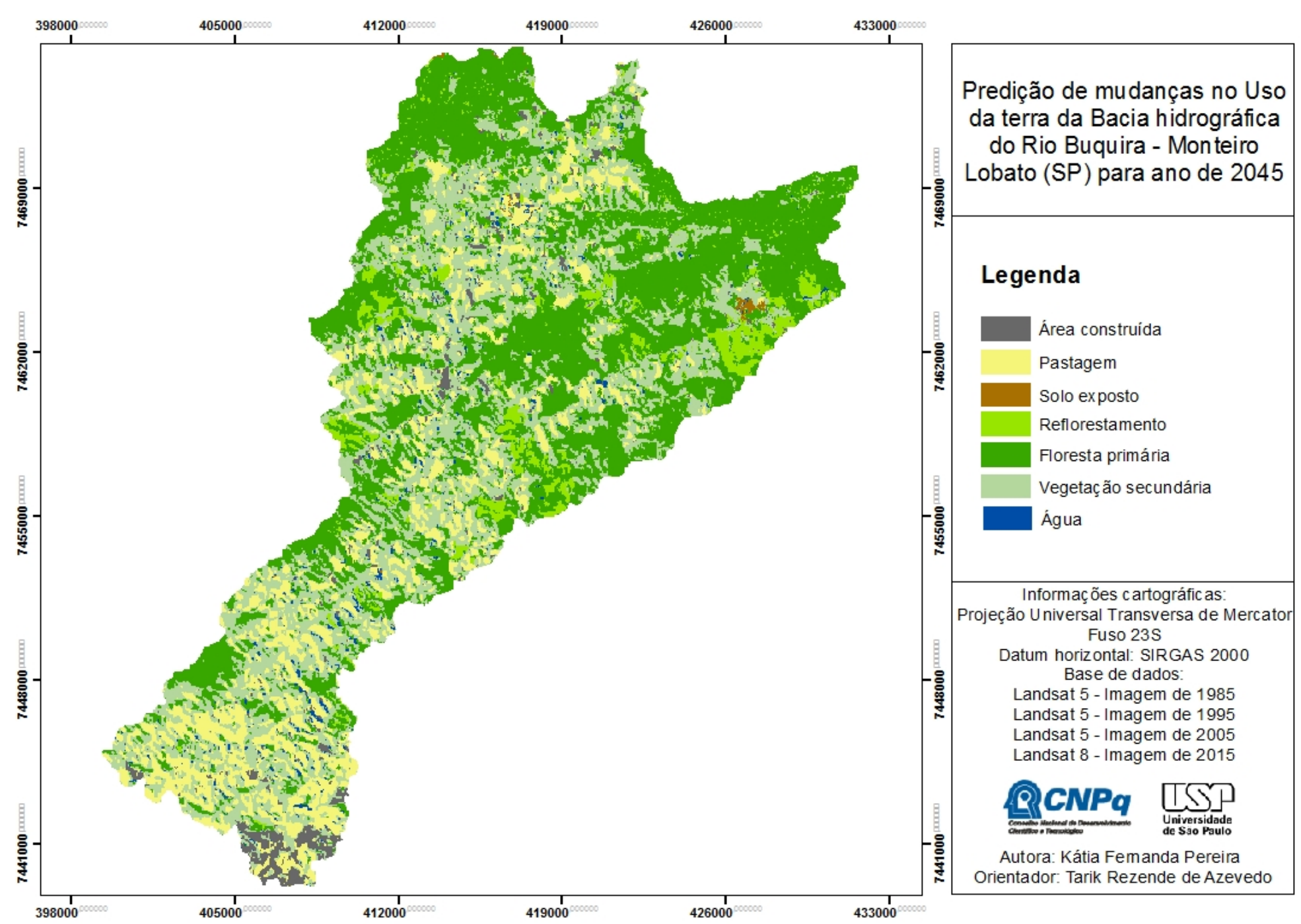

Fonte: Autora 
Como a bacia apresentou um estado ambiental positivo, tendo em vista a Carta de mudanças entre 1985 e 2015, a matriz adotou prognóstico equilibrado para a área da bacia hidrográfica.

Consideramos que a floresta primária e vegetação secundária se mantiveram conservadas, com um pequeno aumento na primeira; a pastagem e o solo exposto diminuíram, os reflorestamentos aumentaram em pequena parcela, a área construída não avançou, mas foram suprimidos alguns pontos existentes em 2015 e a presença da água foi semelhante aos últimos anos estudados. 
Considerações Finais 


\section{CONSIDERAÇÕES FINAIS}

De posse das informações analisadas nesta pesquisa, foi possível identificar que no período avaliado, entre os anos de 1985 e 2015, a Bacia Hidrográfica do Rio Buquira apresentou significativas alterações quanto ao uso e cobertura da terra, confirmando a hipótese inicial deste trabalho.

Após o levantamento das informações, a sistematização do banco de dados e as visitas à campo, identificou-se o uso da terra predominante em cada período, para a posterior discussão e compreensão da dinâmica econômica, social e ambiental inerente em cada cenário.

Desta forma, observou-se que a classe da floresta primária foi a que mais passou por transformações ao longo destes 30 anos. Anteriormente aos anos 80 , a exploração da terra para criação de pastagens, a expansão da urbanização, a construção de vias de acesso urbanas e os reflorestamentos aumentaram de forma vertiginosa, em prejuízo da vegetação nativa. Após este período, com a mudança das legislações ambientais, a criação de áreas legais de app's, o crescimento do turismo sustentável e à trabalhos de conscientização ambiental para a população e proprietários de terra, a bacia presenciou nos anos mais recentes, a recomposição ainda que parcial - da floresta primária.

Se este modelo for preservado, constatamos através da elaboração da Carta de Predições que nos próximos 30 anos (a partir de 2015), a bacia se manterá em conservação.

A delimitação das áreas de APP's em bairros com inundação recorrente foram importantes para constatarmos que realmente as habitações que ali ainda 
permanecem (e que frequentemente são atingidas), estão inseridas em área naturalmente alagadas pelo Rio Buquira.

A confecção da Carta de Suscetibilidade à erosão, juntamente aos trabalhos de campo para averiguação de incidências erosivas provocando assoreamentos na calhas, foram essenciais para investigação de tais alagamentos, onde, na ausência de feições fortemente erodidas nos topos e nas vertentes, atribuímos estes alagamentos e inundações às altas declividades e à velocidade das águas das chuvas.

Espera-se que este trabalho possa contribuir com demais estudos na área de pesquisa e que alcance de forma positiva a população interessada. 


\section{BIBLIOGRAFIA E REFERÊNCIAS}

Livros e artigos:

ARMANI, G. Análise topo e microclimática tridimensional em uma microbacia hidrográfica de clima tropical úmido de altitude. Tese de doutorado. São Paulo: USP, 2009.

AB'SABER, A. N. A geomorfologia do Estado de São Paulo. In: Aspectos geográficos da terra bandeirante. Rio de Janeiro: IBGE, 1954.

ALMEIDA, J. R. et alii. Planejamento ambiental. Rio de Janeiro: Thex/Estácio de Sá, 1999.

ANDRADE, M. B. de C. O uso da terra em São José dos Campos: exemplos de transformações recentes. Dissertação de Mestrado. Faculdade de Filosofia, Letras e Ciências Humanas (FFLCH) da Universidade de São Paulo (USP), 1980.

AZEVEDO, T. R. Derivação antrópica do clima na Região Metropolitana de São Paulo abordada como função do ritmo semanal das atividades humanas. São Paulo: USP, 2001.

BERTONI, J. \& LOMBARDI NETO, F., Conservação do solo. São Paulo: Ícone, 1993.

BERTRAND, Georges. Paisagem e geografia física global: esboço metodológico.

Caderno de Ciências da Terra, n. 13, p. 1-27, 1971

BERTRAND, G. ; BERTRAND, C. Uma geografia transversal e de travessias: o meio ambiente através dos territórios e das temporalidades. Maringá: Masón, 2007.

BONDESAN, A. São José em quatro tempos. São Paulo: Ed. Bentivegna, 1967.

1996.

. São José de ontem e de hoje. São José dos Campos: JAC Editora,

BRANDÃO, I. de L. Dutra 50 anos: quatro séculos em cinco horas. São Paulo: DBA Dórea Books, 2001.

BRASIL. Lei $n^{\circ} 10.257$, De 10 de julho de 2001 - Estabelece diretrizes gerais a política urbana e dá outras providências. Brasília (DF), 2001.

. Lei $\mathrm{n}^{\circ} 11.445$ de 5 de janeiro de 2007 - Estabelece as diretrizes nacionais para saneamento básico. Brasília (DF), 2007.

novembro de 2009.

Ministério do Meio Ambiente. Resolução CONAMA n417 de 23 de

. Lei Federal n.12.651, de 25 de maio de 2012. Dispõe sobre a proteção da vegetação nativa. Brasília: Presidência da República, 2012.

. O Novo Código Florestal - Lei 12.651, 2012.

BLOWERS, A. (Ed.).- Planning for a sustainable environment. A report by the town and country planning Association; Earthscan Publ. Ltd., London, 1993, 139 pgs.

CABRAL, G. M. M. História do Município de Monteiro Lobato. São José dos Campos: Ed. Do Autor, ca.1970. 
CARLOS, A. F. A. "Da 'organização' à 'produção' do espaço no movimento do pensamento geográfico". In: CARLOS, A. F. A ; Souza, M. L. ; SPOSITO, M. E. B. (org.). A produção do espaço urbano: agentes e processos, escalas e desafios. São Paulo: Contexto, 2011.

CAVALCANTI, L.C.S. Cartografia de paisagens: fundamentos. São Paulo: Oficina de Textos, 2014.

CHRISTOFOLETTI, A. "Aplicabilidade do Conhecimento Geomorfológico nos Projetos de Planejamento". In: Geomorfologia: Uma atualização de bases e conceitos. Rio de Janeiro: Bertrand Brasil. 2015.

. Geomorfologia. 2. ed. São Paulo: Edgard Blücher, 1980.

. ; BECKER, B. K. ; DAVIDOVICH, F. R., ; GEIGER, P. P. (orgs.)

Geografia e meio ambiente no Brasil. São Paulo/Rio de Janeiro : Hucitec, 1995.

CONSÓRCIO DE DESENVOLVIMENTO INTEGRADO DO VALE DO PARAÍBA (CODIVAP). São Paulo: CODIVAP, 1971.

CONTI, J. B. Circulação secundária e efeito orográfico na gênese das chuvas na Região Lernordeste Paulista. Tese de Doutorado. IGEOG - USP: São Paulo, 1975.

CORREAA, R. L. "Sobre agentes sociais, escala e produção do espaço: um texto para discussão". In: CARLOS, A. F. A ; Souza, M. L. ; SPOSITO, M. E. B. (org.). A produção do espaço urbano: agentes e processos, escalas e desafios. São Paulo: Contexto, 2011.

COSTA, L. P. Histórias \& Estórias de São José dos Campos. São José dos Campos: JAC Editora, v. 1, 2005.

CREPANI, E. et alii. Curso de Sensoriamento Remoto aplicado ao zoneamento ecológico-econômico. São José dos Campos: INPE, 1996.

Sensoriamento Remoto e Geoprocessamento aplicados ao zoneamento ecológico-econômico e ao ordenamento territorial. São José dos Campos: INPE, 2001.

CUNHA, S. P. ; GUERRA, A. J. T. (orgs.) A questão ambiental: diferentes abordagens. Rio de Janeiro: Bertrand Brasil, 2003.

CUNHA, S. B. da; GUERRA, A. J. T. Geomorfologia e Meio Ambiente. 3. ed. Rio de Janeiro: Bertrand Brasil, 2000.

DIBIESO, E. P. Planejamento Ambiental da Bacia Hidrográfica do Córrego do Cedro - Presidente Prudente/SP. 2007. 157 p. Dissertação (Mestrado em Geografia) Faculdade de Ciências e Tecnologia, Universidade Estadual Paulista, Presidente Prudente.

EASTMAN, J.R. Idrisi for Windows. Manual do usuário. Introdução e exercícios tutoriais. Traduzido. Porto Alegre, UFRGS, Centro de Recursos Idrisi, 1998.

EMBRAPA. Avaliação da Aptidão Agrícola das Terras: proposta metodológica. São Paulo: 2004.

EMBRAPA. Manual de Métodos de Análise de Solo, 2. ed., Rio de Janeiro: Centro Nacional de Pesquisa de Solos, 1997. 
EMBRAPA. Sistema Brasileiro de Classificação de Solos. 2.ed. Brasília: 2006.

FERREIRA, M. C. "Mapeamento de unidades de paisagem com Sistemas de Informação Geográfica: alguns pressupostos fundamentais". In: Geografia, v. 22, n. 1, p. 23-36, 1997.

FIGUEIREDO, R. B. Engenharia Social: Soluções para áreas de riscos. São Paulo: Makron Books, 1994.

FINKLER, R. Planejamento, Manejo e Gestão de Bacias Hidrográficas. Foz do Iguaçu: ANA/ITAIPU, 2013.

FLORENZANO, T. G.; CSORDAS, S. M. Mapa geomorfológico da região do Vale do Paraíba e litoral norte do estado de São Paulo. São José dos Campos: INPE, 1993. 15p. (INPE-5531-PRP/179).

GUERRA, A. J. T.; MARÇAL, M. d. S. Geomorfologia ambiental. Rio de Janeiro: Bertrand Brasil, 2014.

IDRISI. Manual do software. Clark Labs, 2009.

INSTITUTO BRASILEIRO DE GEOGRAFIA E ESTATÍSTICA (IBGE). Enciclopédia dos Municípios Brasileiros, XXX vol. Rio de Janeiro: IBGE, 1958.

. Manual Técnico de Uso da Terra. 2ª ed., Rio de Janeiro: IBGE, 2006.

2012. . Manual Técnico da Vegetação Brasileira. $1^{\text {a }}$ ed., Rio de Janeiro: IBGE, . Censo 2010. Secretaria de Planejamento Urbano - PMSJC, 2010.

. Monteiro Lobato - SP. SF-23-Y-B-V-3 MI-2769-1. Rio de Janeiro: 1973. Mapa Topográfico. Escala 1: 50.000.

. São José dos Campos - SP. SF-23-Y-D-II-1 MI-2769-1. Rio de Janeiro: 1973. Mapa Topográfico. Escala 1: 50.000.

INSTITUTO NACIONAL DE PESQUISAS ESPACIAIS (INPE). Mapa de Uso da Terra: atualização do uso da terra no município de São José dos Campos. SF-23-Y-D-II-1 MI-2769/1. São José dos Campos: 1987. Mapa Temático. Escala 1:100.000.

INSTITUTO DE PESQUISAS TECNOLÓGICAS (IPT). Mapa Geológico do Estado de São Paulo. São Paulo: IPT, 1981.

. Mapa Geomorfológico do Estado de São Paulo. São Paulo: IPT, 1981.

de São Paulo (UGRHI 02), 2014

JENSEN, J. R. Sensoriamento remoto do ambiente: uma perspectiva em recursos terrestres. São José dos Campos: Parêntese, 2009.

GOMES, M. A. F. ; PESSOA, M. C. P. Y. Planejamento ambiental do espaço rural com ênfase para microbacias hidrográficas: manejo de recursos hídricos, ferramentas computacionais e educação ambiental. Brasília: Embrapa Informação Tecnológica, 2010. 
ISSA, M. de A. Análise da paisagem como subsídio ao ordenamento territorial no Município de Monteiro Lobato-SP. Dissertação de Mestrado. (Planejamento Urbano) São José dos Campos: Universidade do Vale do Paraíba, UNIVAP, 2003.

LAMEIRA, W. J. D. M. Mapeamento das unidades ambientais da bacia do rio BuquiraSP: um estudo integrado. 2009. Dissertação de Mestrado. São Paulo: FFLCH.

LANNA, A. E. L. Gestão dos recursos hídricos. In: TUCCI, C.E.M. (Org.). Hidrologia: ciência e aplicação. Porto Alegre: Ed. da Universidade: ABRH: EDUSP, 1997.

LEAL, A. C. Meio ambiente e urbanização na microbacia do Areia Branca - Campinas - São Paulo. Dissertação de Mestrado. Rio Claro: UNICAMP, 1995.

LEAL, A. C. Gestão das Águas no Pontal do Paranapanema - São Paulo. Campinas. Tese. São Carlos: UNICAMP, 2000.

LEAL, A. C. In BRAGA, R., CARVALHO, P.F. Recursos hídricos e planejamento urbano e regional. Rio Claro: UNESP - IGCE, 2003.

MAGALHÃES JÚNIOR, A. P. Indicadores ambientais e recursos hídricos: realidade e perspectivas para o Brasil a partir da experiência francesa. Rio de Janeiro: Bertrand Brasil, 2007.

MASIERO, P. São José dos Campos de Omar Fonseca. São José dos Campos: FVEFundação Valeparaibana de Ensino, 1989.

MASSOQUIM, Nair Glória. Clima e paisagem na mesorregião centro ocidental paranaense. Tese de doutorado. São Paulo: USP, 2010.

MATEO RODRIGUEZ, J. M. ; SILVA, E. V. da ; CAVALCANTI, A. P. B. Geoecologia das Paisagens: uma visão geossistêmica da análise ambiental. Fortaleza: Editora UFC, 2010.

Geografia das paisagens, Geoecologia e Planejamento Ambiental (entrevista). In: Formação, Presidente Prudente: Programa de Pós-Graduação em Geografia, v. 1, n. 10, 2003.

MEIRELES, A. J. de A. (org.) Planejamento Ambiental e Bacias Hidrográficas. Fortaleza: Edições UFC, 2011.

MENDES, C. A. B.; CIRILO, J. A. Geoprocessamento em Recursos Hídricos: princípios, integração e aplicação. Ed. ABRH, Porto Alegre: ABRH, 2001.

MENEGUETTE, A. A. C. Introdução ao Geoprocessamento. Presidente Prudente: Ed. Do Autor, 1994.

MENEZES, U. T. B. de. A paisagem como fato cultural. In: YÁZIGI, E. (org.) Turismo e paisagem. São Paulo: Contexto, 2002.

MILKOV, F.N. Esfera das paisagens da Terra. Moscou: Editora Misl, 1970.

MONBEIG, P. Papel e valor do Ensino da Geografia e de sua Pesquisa. Rio de Janeiro: IBGE, 1957.

MONTEIRO, C. A. de F. Geossistemas: A História de uma Procura. São Paulo: Contexto/Geousp: 2000. 
MOREIRA, M. A. Fundamentos do sensoriamento remoto e metodologias de aplicação. 3. ed. Viçosa: Ed. UFV, 2005.

MOROZ - CACCIA GOUVEIA, I. C. Da originalidade do sítio urbano de São Paulo às formas antrópicas: aplicação da abordagem da Geomorfologia antropogênica na bacia hidrográfica do Rio Tamanduateí, na Região Metropolitana de São Paulo. Tese de doutorado. Universidade de São Paulo, FFLCH, 2010.

MOTA, S. Urbanização e meio ambiente. Rio de Janeiro: Fortaleza: ABES, 2011.

MÜLLER, Nice Lecocq. O Fato Urbano na Bacia do Rio Paraíba. Rio de Janeiro: IBGE, 1969.

NAZAKAWA, V. Akihiko. Carta Geotécnica do Estado de São Paulo: escala 1:500.000. 1.ed. São Paulo: Instituto de Pesquisas Tecnológicas, 1994.

NEGRI, Barjas. "As políticas de descentralização industrial e o processo de interiorização em São Paulo: 1970-1985”. In: TARTAGLIA, J. C. \& OLIVEIRA, O. L. Modernização e desenvolvimento no interior de São Paulo. São Paulo: Fundunesp, 1988.

NORDERMAN, L.M.M.; DANELON, O. M. Entradas atmosféricas de elementos de origem natural e antroponência na bacia hidrográfica do Rio Buquira - SP. São José dos Campos: INPE, 1990.

NOVO, Evelyn M.L. de Morais. Sensoriamento remoto: princípios e aplicações. São Paulo: Blucher, 2008.

NUNES, L. H. Urbanização e Desastres Naturais: abrangência América do Sul. São Paulo: Oficina de Textos, 2015.

OHARA, T. Zoneamento geoambiental da região do alto-médio Paraíba do Sul (SP) com Sensoriamento Remoto. 1995. Tese de Doutorado (Geografia Física) Rio Claro, UNESP.

OLIVEIRA, J. O. S. de; GOMES, C. "Introdução à urbanização contemporânea: espaços e paisagens na região do Vale do Paraíba (SP)". In: COSTA, S. M. F. de; MELLO, L. F. de. Crescimento urbano e industrialização. São José dos Campos: Intergraf, 2010

OLIVEIRA, J. B. et al. Mapa pedológico do Estado de São Paulo. Instituto Agronômico: Campinas: 1999.

PASSOS, M. M. dos. Dinâmicas socioambientais, desenvolvimento local e sustentabilidade na raia divisória São Paulo, Paraná, Mato Grosso do Sul. Projeto temático aprovado junto à FAPESP, Presidente Prudente, 2005.

PENEDO, A. Arquitetura moderna: São José dos Campos. São José dos Campos: A. Penedo, 1997.

PEREIRA, C. J. A cidade, a fábrica e a juventude: a mão-de-obra juvenil na Fábrica de Louças "Santo Eugênio" e o contexto industrial de São José dos Campos-SP (19211973). Dissertação de Mestrado (História Econômica). São Paulo: FFLCH, 2009.

PEREIRA, K. F. Zoneamento Geoambiental da Bacia Hidrográfica da Represa Laranja Doce - Martinópolis (SP). 2012. Dissertação de Mestrado (Geografia Física). Rio Claro, UNESP. 
PERROTA, M. M. et al. Mapa Geológico do Estado de São Paulo. CPRM: São Paulo, 2005.

PINHEIRO, A. (org) Vulnerabilidade Ambiental - Brasília: MMA, 2007.

PINTO, E. J. de A.; AZAMBUJA, A. M. S. de; FARIAS, J. A. M.; SALGUEIRO, J. P.de B.; PICKBRENNER, K. (Coords.). Atlas pluviométrico do Brasil: isoetas mensais, isoetas trimestrais, isoetas anuais, meses mais secos, meses mais chuvosos, trimestres mais secos, trimestres mais chuvosos. Brasília: CPRM, 2011.

PIROLI, E.L. et al. Análise das mudanças no uso do solo da microbacia do córrego das Furnas, município de Ourinhos - SP, entre os anos de 1972 e 2007, e dos impactos sobre suas áreas de preservação permanente, apoiada em geoprocessamento. Anais XV Simpósio Brasileiro de Sensoriamento Remoto - SBSR, Curitiba: INPE, 2011.

PIVOTT, C. A construção compartilhada de um plano de turismo para Monteiro Lobato, SP: a sustentabilidade como horizonte. Tese de Doutorado (Psicologia Social). São Paulo: USP, FFLCH, 2014..

PREFEITURA MUNICIPAL DE MONTEIRO LOBATO. Plano diretor de macrodrenagem do município de Monteiro Lobato, termo de referência, Monteiro Lobato: 2014.

PREFEITURA MUNICIPAL DE SÃO JOSÉ DOS CAMPOS. Plano diretor de desenvolvimento integrado de SJC - Diretrizes. São José dos Campos, 2006.

Cidade Viva 2011. Banco de dados do Spring [Cd Rom]. Secretaria Municipal de Planejamento Urbano: SJC, 2011.

REANI, R. T. Organização do espaço e políticas públicas ambientais no município de São José dos Campos - SP. Tese de doutorado. São Paulo: FFLCH, 2012.

REBOUÇAS, A. da C. ; BRAGA, B. ; TUNDISI, J. G. Águas doces no Brasil. Capital ecológico, uso e conservação. 3. ed. São Paulo: Escrituras Editora, 2006.

RODRIGUES, C. Avaliação do impacto humano da urbanização em sistemas hidrogeomorfológicos: desenvolvimento e aplicação de metodologia na Grande São Paulo. Revista do Departamento de Geografia, v.20, 2010.

Geomorfologia Aplicada: Avaliação de experiências e de instrumentos de planejamento físico-territorial e ambiental brasileiros. 1997. Tese de Doutorado. São Paulo, Universidade de São Paulo, FFLCH.

Morfologia original e morfologia antropogênica da definição de unidades espaciais de planejamento urbano: exemplo na metrópole paulista. Revista do Departamento de Geografia, v.17, 2005.

RODRIGUEZ, J. M. M. et. al. Geoecologia das Paisagens: uma visão geossistêmica da análise ambiental. 3 ed. Fortaleza: Edições UFC, 2010.

RODRIGUEZ, José Manuel Mateo; SILVA, Edson Vicente da. Planejamento e gestão ambiental: subsídios da geoecologia das paisagens e da teoria geossistêmica. Fortaleza: Edições UFC, 2013. 
ROSA FILHO, A. et al. Os deslizamentos de encostas nas favelas em áreas de risco da "Suíça Brasileira": Campos do Jordão (SP) In GERARDI, L. H. de O.; FERREIRA, E.R. Saberes e Fazeres Geográficos. Rio Claro: UNESP/IGCE: AGETEO, 2008.

ROSS, J.L.S. Geomorfologia, Ambiente e Planejamento. São Paulo: Contexto, 1990. . ; MOROZ, I.C. Mapa geomorfológico do Estado de São Paulo. 1997.

Arquivos em shapefile.

ROSSI, Marcio. Mapa pedológico do Estado de São Paulo: revisado e ampliado. São Paulo: Instituto Federal, 2017, V. 1. 118p. (inclui mapas)

RUFFATO, L. Rotas do comércio do Vale do Paraíba. São Paulo: SESC/Museu da Pessoa, 2004.

SAINT-EXUPÉRY, Antoine. O pequeno príncipe. 48. ed. Trad. de Dom Marcos Barbosa. Rio de Janeiro: Agir, 2006.

SÁNCHEZ, L. E. Recuperação de Áreas Degradadas: Um campo multidisciplinar de pesquisas. Seminário Unesp Rio Claro, 24 de novembro de 2006.

SANTANA, D. P. Manejo integrado de Bacias hidrográficas. Sete Lagoas: Embrapa, 2003.

SANTOS, A. P. dos. Arquitetura industrial: São José dos Campos. São José dos Campos: A.P. Santos, 2006.

SANTOS, M. A Natureza do Espaço: técnica e tempo, razão e emoção. 2. ed. São Paulo : Hucitec, 1997. . Espaço e sociedade (ensaios). Petrópolis: Vozes, 1979.

SANTOS, Rozely Fereira dos. Planejamento Ambiental: teoria e prática. São Paulo: Oficina de Textos, 2004.

SARACENI, V.; FURLAN, S. A. Atlas ambiental: São José dos Campos, SP, Brasil. São Paulo: Geodinâmica, 2012.

SECRETARIA DA AGRICULTURA DO ESTADO DE SÃO PAULO, Instituto Agronômico: Aerofoto Natividade Ltda., 1962.

SETTI, A. A. Introdução ao gerenciamento de recursos hídricos. Brasília: Agência Nacional de Energia Elétrica e Agência Nacional de Águas, 2001.

SILVA, J. X., ZAIDAN, R. T. . Geoprocessamento \& análise ambiental: aplicações. Rio de Janeiro: Bertrand Brasil, 2004.

SIQUEIRA, J. C. de. Nossa cidade de São José dos Campos. São José dos Campos: Fundação Cassiano Ricardo, 1991.

SOUZA, E. R.; FERNANDES, M. R. Sub-bacias hidrográficas: unidades básicas para o planejamento e a gestão sustentáveis das atividades rurais. Informe Agropecuário, Belo Horizonte, v. 21, n. 207, nov./dez. 2000.

SOUZA, L.B. et al. "Adoção de ajustamentos individuais e coletivos aos riscos de escorregamentos na Vila Mello Reis, Juiz de Fora (MG)". In: GERARDI, L. H. de O.; FERREIRA, E.R. Saberes e Fazeres Geográficos. Rio Claro: UNESP/IGCE: AGETEO, 2008. 
SPOSITO, M. E. B. A produção do espaço urbano: agentes e processos, escalas e desafios. São Paulo: Editora Contexto, 2011.

TOLEDO, O. M. São José do Orlando, dos Campos, do Bacilo de Koch. São José dos Campos: JAC Editora, 1995.

TÔSTO, S. G. Geotecnologias e Geoinformação: o produtor pergunta, a Embrapa responde. Brasília: Embrapa, 2014.

TUNDISI, J. G. Águas doces no Brasil. Capital ecológico, uso e conservação. 3. ed. São Paulo: Escrituras Editora, 2006. . O Futuro dos Recursos. São Carlos: Multi Ciência, 2003.

TUCCI, Carlos E. M. Gestão da água no Brasil. Brasília: UNESCO, 2001.

VENTURI, L. A. B. (org.). Praticando Geografia: técnicas de campo e laboratório. São Paulo: Oficina de Textos, 2009.

WISNER, B. et al. . At risk: natural hazards, people's vulnerability, and disasters. 2nd. London/New York: Routledge, 2004.

ZOCCAL, J. C Soluções Cadernos de estudos em conservação do solo e água. Presidente Prudente: CODASP, 2007.

Documentos eletrônicos:

BOLETIM INFORMATIVO DO COMITÊ DAS BACIAS HIDROGRÁFICAS DO RIO PARAÍBA DO SUL (CBH-PS). Vários números. Disponível em:

<http://www.comiteps.sp.gov.br/publicacoes>. Acesso em: 25 nov. 2014.

BRASIL. Lei Federal $\mathrm{n}^{0} 12651 / 12$. Disponível em: http://www.planalto.gov.br/ccivil_03/_ato2011-

2014/2012/lei/L12651compilado.htmAcesso em 05.02.2016

CULLEN, J. Status: Landsat \& USGS Geography. 2010. Disponível em:

$<$ http://landsat.usgs.gov/documents/2_Cullen_Perspectives_on_the_future_of_Lands at.ppt >. Acesso em: 31 de jan de 2017.

CÂMERA MUNICIPAL DE SÃO JOSÉ DOS CAMPOS. Lei Orgânica do Município. Disponível em: <http://camarasjc2.hospedagemdesites.ws/clicknow/arquivo/leiorganica-do-municipio/3f6c067e4cc5320b2745.pdf.> Acesso em: 13.07.2015

COMITÊ DA BACIA HIDROGRÁFICA DO PARAÍBA DO SUL. $<w w w . c o m i t e p s . s p . g o v . b r>$ Acesso em: 30.09.2014

EMBRAPA. Satélite Landsat. 2013. Disponível em:

<http://www.sat.cnpm.embrapa.br/conteudo/landsat.htm>. Acesso em: 02 junho 2014.

HERZ. R. e DE BIASI, M. in A carta clinográfica: os métodos de representação e sua confecção. Disponível em:

$<$ http://www.geografia.fflch.usp.br/inferior/laboratorios/lcarto_ori/PAGINA\%20DO\%20 LABCART/artigos/artigo02.html>. Acesso em: 06 mar. 2016. 
IBGE. Brasil em síntese. São Paulo. São José dos Campos. In:

$<$ https://cidades.ibge.gov.br/brasil/sp/sao-jose-dos-campos/historico>. Acesso em: 06 jul. 2018.

INPE (Instituto Nacional de Pesquisas Espaciais). Landsat informações. Disponível em http://www.dgi.inpe.br/documentacao/satelites/landsat. Acesso em 07.08.2017.

INSTITUTO NACIONAL DE METEOROLOGIA (INMET). Disponível em: www.inmet.gov.br/sim/abre_graficos.php. Acesso em: 03.03.2016

INSTITUTO BRASILEIRO DE GEOGRAFIA E ESTATÍSTICA (IBGE). $<w w w . c i d a d e s . i b g e . g o v . b r>$ Acesso em: 30.09.2014

JORNAL O VALE. Rio Buquira sobe e desaloja 120 na zona norte de São José. Disponível em: <http://www.ovale.com.br/nossa-regi-o/rio-buquira-sobe-e-desaloja120-na-zona-norte-de-s-o-jose-1.368645>. Acesso em 14.03.2015.

NATIONAL AERONAUTICS AND SPACE ADMINISTRATION (NASA). The Landsat

Program. Disponível em: <http://landsat.gsfc.nasa.gov/>.

Acesso em: 31 jan. 2017.

PORTO, M. F. A.; PORTO, R. L. L. Gestão de bacias hidrográficas. In: Estud. Av. [online], vol.22, no.63, São Paulo: 2008. Disponível em: $<$ http://www.scielo.br/scielo.php?pid=S0103-

40142008000200004\&script=sci_arttext>. Acesso em: 30 out. 2015.

PREFEITURA MUNICIPAL DE MONTEIRO LOBATO Disponível em: <www.monteirolobato.sp.gov.br>. Acesso em: 30.09.2014

PREFEITURA MUNICIPAL DE SÃO JOSÉ DOS CAMPOS. Decreto 28399. Disponível em: $\quad$ http://www.al.sp.gov.br/repositorio/legislacao/decreto/1957/decreto-2839915.05.1957.html. Acesso em: 12.07.2015

Decreto

250.

Disponível

em:

<http://www.sjc.sp.gov.br/legislacao/Decretos/1958/250.pdf> Acesso em: 12.07.2015

Decreto

286.

Disponível

em:

<http://www.sjc.sp.gov.br/legislacao/Decretos/1959/286.pdf> Acesso em: 12.07.2015

\begin{tabular}{cccc} 
Decreto & 1437. & Disponível & em: \\
\hline <http://www.sjc.sp.gov.br/legislacao/Decretos/1971/1437.pdf> & Acesso & em:
\end{tabular} 12.07.2015

Decreto

1792.

Disponível

em:

<http://www.sjc.sp.gov.br/legislacao/Decretos/1974/1792.pdf> Acesso em: 12.07.2015

Decreto

1826.

Disponível

em:

<http://www.sjc.sp.gov.br/legislacao/Decretos/1975/1826.pdf> Acesso em: 12.07.2015

Decreto 1623.1 Disponível

em:

<http://www.sjc.sp.gov.br/legislacao/Leis/1971/1623.pdf> Acesso em: 12.07.2015

Decreto

4636.

Disponível

em:

<http://www.sjc.sp.gov.br/legislacao/Leis/1994/4636.pdf> Acesso em: 12.07.2015 
Lei complementar n³06/06. Disponível em: http://www.sjc.sp.gov.br/legislacao/Leis\%20Complementares/2006/306.pdf Acesso em 12 de ago de 2019

. Caderno Diagnóstico do Plano Diretor de 1995. Disponível em

<http://www.sjc.sp.gov.br/secretarias/planejamento_urbano.aspx.> Acesso em: 23 de nov. de 2016.

. Caderno Diagnóstico da Lei de Zoneamento de 2010. Disponível em <http://www.sjc.sp.gov.br/secretarias/planejamento_urbano.aspx.> Acesso em: 23 de nov. de 2016.

. Plano municipal de saneamento básico. 2008. Disponível em <http://www.sjc.sp.gov.br/secretarias/obras/simisa/plano_municipal.aspx.> Acesso em: Acesso em: 23 de nov. de 2016.

<http://servicos2.sjc.sp.gov.br/media/667370/sjdados_2016.pdf>. Acesso em: 06 jul. 2018.

SÃO JOSÉ DOS CAMPOS. Lei complementar $n^{\circ} 428,9$ de agosto de 2010. Estabelece as normas relativas ao parcelamento, uso e ocupação do solo em São José dos Campos, e dá outras providências. Disponível em: <http://www.ceaam.net/sjc/legislacao/> Acesso em: 23 nov.2016.

USGS. United States Geological Survey. Landsat Thematic Mapper (TM). $<$ http://landsat.usgs.gov/band_designations_landsat_satellites.php>. Acesso em: 11 jan. 2017.

Jornais:

"O VALEPARAIBANO".

07/06/1972; 27/07/1972; 27/07/1973; 06/06/1974; 20/06/1974; $08 / 08 / 1974$;

07/03/1985; 20/01/1988; 01/01/1989; 29/01/1989; 06/01/1995; 12/01/2005.

"O VALE"

27/07/2019.

Fontes de arquivo:

Museu Paulista da Universidade de São Paulo. Serviço de Documentação Histórica e Iconografia. Coleção Wasth Rodrigues, Documento IC 10560, cjwr, A2Pr39Cx5.

Arquivo Público Municipal (APM) de São José dos Campos-SP (jornais "O Valeparaibano"). 
Entrevista:

PIMENTEL, José. Entrevista. Entrevistadora: Kátia Fernanda Pereira. DEFESA CIVIL: São José dos Campos, 2016. 